\author{
UNIVERSIDADE DE SÃO PAULO \\ FaCUldade de Filosofia, Letras E CiênCias Humanas \\ DePartamento de Letras Modernas
}

Programa de Pós GraduaÇão em Estudos Lingüísticos e Literários EM INGLÊS

\title{
SEAMUS HEANEY: A POLIFONIA (DA) POÉTICA DO EXÍLIO
}

\author{
Viviane Carvalho da Annunciação
}

DissertaÇão DE Mestrado APRESEntada À FACUldade de Filosofia, Letras E CiÊnCias Humanas da Universidade de São PAULO.

Orientadora: Profa. Dra. Laura Patrícia Zuntini de Izarra

SÃo PAULO

2008 


\author{
UNIVERSIDADE DE SÃO PAULO \\ FaCUldade de Filosofia, Letras E CiênCias Humanas \\ DEPARTAMENTO DE LETRAS MODERNAS
}

Programa de Pós GraduaÇão em Estudos Lingüísticos e Literários EM INGLÊS

\title{
SEAMUS HEANEY: A POLIFONIA (DA) POÉTICA DO EXÍLIO
}

\author{
Viviane Carvalho da AnNunciação
}

DisSERTAÇão DE MESTRADO APRESENTADA À Faculdade de Filosofia, Letras e Ciências Humanas da Universidade de São Paulo como PARTE DOS REQUISITOS PARA OBTENÇÃO DO TÍTULO DE MeSTRE EM LeTRAS.

Orientadora: Profa. Dra. Laura Patrícia Zuntini de Izarra

\author{
SÃo PAULO \\ 2008
}




\section{Agradecimentos}

À Prof. Dra. Laura Patrícia Zuntini de Izarra pela orientação, afeição, incentivo e seriedade profissional.

Aos meus pais e familiares pelo apoio, incentivo e sacrifícios durante minha formação. Agradeço em especial ao meu tio João Ernesto de Carvalho pelo exemplo, e avô Vicente de Carvalho Netto pela inspiração. À Maria, Iza e Márcia pelo valioso carinho.

Aos meus queridos professores e colegas da Universidade de São Paulo. Agradeço em especial à Profa. Dra. Munira Mutran pela interlocução, ao Prof. Dr. Nicholas Brown e Profa. Dra. Cielo Festino pela colaboração na banca de qualificação. Agradeço a amiga Alvany Noronha Guanaes, pelo apoio, e a Elton Luiz Furlanetto pela amizade e arguta revisão.

À Fundação de Amparo à Pesquisa do Estado de São Paulo - FAPESP - pela bolsa de estudos em nível de Mestrado que me foi concedida.

A tentativa de agradecer nominalmente a todos que diretamente ou indiretamente colaboraram para a realização desta tese é uma tarefa que certamente será traída pela memória. Portanto, agradeço sinceramente a todos os funcionários, pós-graduandos e professores do Departamento de Letras Modernas que através de seu trabalho e amizade colaboraram para a realização desta dissertação, assim como para minha formação.

De forma especial, quero agradecer carinhosamente a todos os membros da Associação Brasileira de Estudos Irlandeses (ABEI) com os quais tive a oportunidade de conviver durante estes anos. 


\section{SUMÁRIO}

$\begin{array}{ll}\text { RESUMO } & 05\end{array}$

$\begin{array}{ll}\text { ABSTRACT } & 06\end{array}$

$\begin{array}{ll}\text { INTRODUÇÃO } & 07\end{array}$

CAPítulo 1 - A Polifonia PoÉtica De “Eus”

Da periferia ao Centro ou do Centro à Periferia 38

Heaney por Heaney - A Polifonia Poética da Subjetividade 48

A Música do Silêncio: Ecos do Passado $\quad 54$

A Música das Imagens Surrealistas $\quad 69$

CApítulo 2 - Os Efeitos Metonímicos do Exílio 81

O Prazer e Culpa $\quad 91$

O Exílio e a Culpa 100

A Violência e a Culpa 107

A Violência e o Olhar Onírico 115

$\begin{array}{ll}\text { CAPÍtUlO } 3 \text { - A CONSCIÊNCIA DO RETORNO } & 127\end{array}$

A Fome: Recusa Consciente ou Privação Forçada 128

A Epifania dos Objetos 136

A Metafísica: O reconhecimento do Misticismo

Irlandês através de Juan de La Cruz $\quad 147$

A Solidariedade $\quad 154$

$\begin{array}{ll}\text { CONCLUSÃO } & 162\end{array}$

$\begin{array}{lr}\text { BIBLIOGRAFIA } & 170\end{array}$ 
RESUMO:

Na pesquisa de Mestrado intitulada "Seamus Heaney: Polifonia (da) Poética do Exílio" concluímos que o poeta desestabiliza a noção de subjetividade à medida que se afasta de seu lugar de origem. Nesse sentido, encontramos o eu lírico em uma peregrinação católica em que reconstrói, simbolicamente, as fragmentações e divisões de sua comunidade nativa, uma vez que ele próprio cria diálogos imaginários entre seu passado, presente e futuro. Rompendo com as noções lineares de espaço e tempo, Heaney compõe uma poética do exílio como fruto de uma consciência polifônica, em que a atividade poética depende: 1 . das personas (subalternas ou literárias) que fizeram parte de sua constituição artística; 2. da culpa de ter-se afastado da Irlanda do Norte em meio à crise civil; e 3. o desejo de liberdade proveniente da visão crítica de James Joyce. Ao fazer movimentos circulares em torno de si mesmo e de sua terra, o autor reproduz o símbolo celta do triskele, através do qual ele reflete sobre as implicações do fazer poético do autor na literatura contemporânea.

Palavras chave: poesia irlandesa, exílio, intertextualidade, subjetividade, Seamus Heaney. 


\begin{abstract}
:
The masters research entitled "Seamus Heaney: Polyphonic Poetics of Exile" enabled us to conclude that, as the poet distances himself from his native homeland, he de-constructs the notion of poetic subjectivity. Therefore, in order to display this feature, the persona embraces a catholic pilgrimage through which he reconstructs symbolically the fragmentations and divisions of his own community, whilst he himself creates imaginary dialogues between his past, present and future. Overcoming the traditional chronotope of linear time and space, Heaney gives rise to an exile poetics whose polyphonic consciousness stems from: 1. the personas (subaltern or literary) that have belonged to his artistic constitution; 2. the guilt of distancing himself from Northern Ireland in the middle of a civil war; and 3. the desire of liberty provided by the critical vision of James Joyce. As long as he performs circular movements around himself and his land, the author reproduces the Celtic symbol triskele through which he reflects about the implications of writing poetry in contemporary society.
\end{abstract}

Key words: Irish poetry, exile, intertextuality, subjectivity, Seamus Heaney; 


\title{
INTRODUÇÃO
}

\author{
“The dotted line my father's ashplant made \\ On Sandymount Strand \\ Is something else the tide won't wash away." \\ (HEANEY, 1998, p. 236).
}

\section{SEAmus HeAney: PoÉtica do Exílio}

Seamus Heaney, poeta da Irlanda do Norte laureado com o prêmio Nobel de 1995, afirma, na sua gênese poética, que "Entre o dedo e o dedão a caneta/ Parruda pousa; como arma pega/... Vou cavar com ela" (1998, p. 31) ${ }^{1}$, sugerindo um forte compromisso político e social. Contudo, após vinte anos de escrita, ele ressalta que "O importante é escrever/ por prazer. Cultive um desejo de trabalho/ que imagine um porto como suas mãos à noite/... Fique na tangente/ quando ampliam o círculo, é chegada a hora/ de nadar sozinho" (1998, p. 83) ${ }^{2}$, desviando abertamente sua tonalidade ativista para preocupações metapoéticas e artísticas. Portanto, a partir desses dois excertos, podemos compreender a própria condição desse artista contemporâneo cujas tônicas e dominantes são tanto inquietações de ordem social como reflexões de cunho artístico, especialmente sobre como a forma poética é capaz de abarcar tais temas. Em um contexto histórico em que a importância da "função humanizadora" (CANDIDO, 2002, p. 92) da literatura é minimizada devido ao utilitarismo do capital multinacional, às guerras econômicas, conflitos sociais e segregações raciais, os poemas de Heaney surgem como uma tentativa de resposta enviesada a todas as atrocidades que o século XX testemunhou, e continua testemunhando no recém iniciado século XXI.

De acordo com um dos críticos de maior importância no contexto de crítica literária brasileira, Antonio Candido (2002, p. 83), a literatura possui uma "força humanizadora" que não deve ser confundida com "sistema de obras", mas vista como "algo que exprime o

\footnotetext{
${ }^{1}$ Original do poema "Digging": "Between my finger and my thumb/ The squat pen rests, snug as a gun/... I'll dig with it”. Heaney, Seamus. Tradução: José Antonio Arantes. (ARANTES, 1998, p. 31)

${ }^{2}$ Original: The main thing is to write/ for the joy of it. Cultivate a work-lust/ that imagines it's heaven like hands at night/... Keep a tangent when they make the circle wide,/ it's time to swim. (HEANEY, 1998, p. 261)
} 
homem e depois atua na própria formação do homem", ou seja, ela é a "representação de uma dada realidade social e humana que faculta maior inteligibilidade com relação a essa

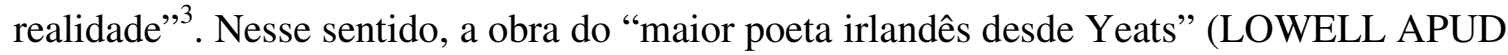
NOLASCO, 1966) exemplifica tal função, pois desde o início de sua carreira, Heaney não só tomou consciência de suas raízes pessoais, bem como do passado histórico de sua nação, mas também de uma tradição que o precede: "o poeta faz poemas, mas é a poesia que faz o poeta; para a poesia, as gerações são episódios" (CANDIDO, 2002, p. 160). Com isso, ao mesmo tempo em que ele aceita um cânone poético, por lidar com regras estilísticas estabelecidas através da história literária, ele o redefine de acordo com parâmetros estabelecidos por sua subjetividade em contínuo processo criativo com a sociedade que a urde.

Dentro do contexto dessas relações literárias, Heaney descreve um percurso muito particular que estaria intimamente relacionado ao legado histórico da Irlanda: o exílio. Embora associada ao seu caráter coercivo, visto que esta prática entra primeiramente em voga na Grécia e Roma antigas (ALFÖLDY, 1989, p. 69-72) como forma de punição: o cidadão, os cidadãos, ou até mesmo famílias inteiras que não se adaptassem às regras de convívio público deveriam ser deslocados para longe das práticas citadinas, na sociedade moderna o conceito adquire novas significâncias. Se em nossa sociedade, de acordo com Edward Said (2003, p. 46-60), o exílio pode ser concebido, na sua roupagem individual e voluntária, como a resistência nostálgica de uma subjetividade desconfortável com a tradição e, no seu aspecto coletivo e político, como uma atitude que provoca inúmeras fraturas entre o indivíduo e sua terra natal, a Irlanda parece possuir ambas heranças. Ao mesmo tempo em que o passado colonial da ilha perpetua episódios trágicos de exílio em massa por razões econômicas e políticas (diásporas e/ou emigrações) como aqueles provindos da Grande Fome em 1845, escritores das mais variadas afiliações, como Bernard Shaw, James Joyce e Samuel Beckett, resolvem voluntariamente deixar seu país para, sem pressões políticas, re-inventarem sua escrita.

\footnotetext{
${ }^{3}$ Conceito sobre literatura desenvolvido no texto "A Literatura e a Formação do Homem”, no qual o crítico compreende a arte - e o artista que a produz - em relação à história e à tradição literária que o antecede. Essa visão possibilita que a tradição seja transformada pela nova contribuição, e essa, por sua vez, transformada, continuamente, pela tradição. Com uma visão mais aberta à sociologia, Candido retoma, implicitamente, as idéias desenvolvidas por T. S. Eliot no conhecido ensaio “Tradição e Talento Individual”. (CANDIDO, 2002, p. 83).
} 
Derivadas dessa diferença entre os diferentes tipos de exílio, essa complexa problemática possuí quatro fases, segundo Chris Curtin (CURTIN, 1988, p. 80). A primeira, chamada por Heaney de Sense of Place, é aquela em que há reconhecimento da identidade irlandesa através das paisagens geográficas e culturais ${ }^{4}$, ou seja, a Irlanda real torna-se simbólica intelectualmente. Na segunda, há uma quebra da conexão entre sujeito e comunidade, fazendo com que os posicionamentos individuais sejam valorizados e haja a necessidade do afastamento. Embora Curtin veja essas duas fases como parte do mecanismo de exílio, a nosso ver, elas seriam um prenúncio psicológico - ou até mesmo um exílio psicológico - pelo qual a subjetividade é formada. Considerando que artistas da Renascença Literária irlandesa desenvolveram um senso de identidade baseado na exploração da língua e folclore nativos, (CURTIN, 1988) é relevante o fato de esses autores estarem cindidos da realidade mesma que procuram recriar, pois não pertencem às camadas populares. Sendo assim, baseados no conceito tradicional grego-romano de exílio interno um criminoso mandado para outra parte de seu próprio país - acreditamos que o poeta, na sua busca por uma identidade própria, depara-se com essa noção de proximidade e estranhamento previamente representada pelas gerações anteriores. Seria como se, no próprio reconhecimento da terra natal, houvesse algo de estrangeiro e deslocado.

Embora a temática do exílio no olhar de Seamus Heaney seja social e histórica, uma vez que a Irlanda torna-se um espaço fechado à imaginação pelo colonialismo, porquanto a dominação britânica a moldou de acordo com estereótipos, ela é, como defende Seamus Deane, parte constitutiva do panorama cultural irlandês posterior ao acordo de 1922. Nas palavras do crítico:

Quero sugerir que as formas de descobrir o Celta é uma daquelas idéias historicamente construídas, que reivindicam sobre si mesmo, libertação da história através de duas posições que foram tipicamente adaptadas pelos escritores irlandeses no começo do século - ocultismo e exílio. Essas posições, além de serem próximas, pretendem criar o que venho dizendo que não era possível no horizonte de possibilidades da escrita irlandesa - a posição de distância, a precondição para uma versão de estética que poderia, no seu afastamento do real, encontrar meios pelo qual o real fosse totalizado

\footnotetext{
${ }^{4}$ Quando me refiro ao conceito de "paisagem cultural”, estou retomando David Schneider que argumenta: "a cultura é um sistema de símbolos e significados. Compreende categorias ou unidades e regras sobre relações e modos de comportamento". A noção de paisagem é acoplada para designar como essa geografia pode se tornar um símbolo com determinada função na sociedade. (SCHNEIDER, 1968).
} 
em uma narrativa estruturada que pudesse distintivamente e consistentemente, prevalecer sobre as outras, naquilo que o caráter nacional nunca pode alcançar como point d'appui, a força do caráter racial (DEANE, 1997, p. 11) ${ }^{5}$.

De acordo com tal herança cultural dupla, Heaney expressa, nessas duas primeiras fases de exílio descritas por Curtin - da percepção do espaço físico e subjetivo em relação à comunidade - o desejo de se afastar da Irlanda, que está operando desde o princípio de seu trabalho. Contudo, ao invés de ser explicitado, esse desejo de exílio é expresso através da forma, portanto, no processo de descoberta individual e subjetivo, o poeta se depara com o panorama cultural, retornando às configurações artísticas de seu lugar de origem. Logo, a construção de sua subjetividade se dá na descoberta de uma cultura largamente reinventada, exilada e estranha. O primeiro capítulo de nosso trabalho Seamus Heaney: Poética do Exílio $^{6}$ contém análises de poemas que demonstram como esse exílio psicológico, ou um desejo de exílio, é manifesto na obra poética do autor. Dentre tais poemas, destacam-se "Digging" e "Antaeus" (Death of a Naturalist, 1966), "The Given Note" (Door Into the Dark, 1969) e "Serenades" (Wintering Out, 1972).

A terceira fase descrita por Curtin se refere à busca da integridade e objetividade artísticas que têm a potencialidade de serem liberadas por uma posição distanciada. Assim, esse afastamento funcionaria - mesmo que apenas teoricamente - como um filtro que faz o artista rever e canalizar lealdades e emoções. E, finalmente, haveria uma quarta fase em que o autor volta ao lar e tenta reconstruir sua vida no lugar que rejeitou, ou do qual foi rejeitado. No caso de Heaney, esse retorno é fragmentado, pois, como conseqüência do Nobel de literatura e das aulas ministradas em diversos lugares do mundo, especialmente em Harvard, o poeta se encontra na ponte aérea entre República da Irlanda - Wicklow - e

\footnotetext{
${ }^{5}$ Seamus Deane problematiza as fontes literárias que precederam a literatura contemporânea na Irlanda. Original: "I want to suggest ways of pursuing the Celt as one of those historically produced ideas that claims for itself freedom from history through two positions that were famously adopted by Irish writers at the turn of the century - occultism and exile. These positions are intimate with one another; more than that, they are positions that attempt to create what I have been saying had not until then been within the horizon of Irish writing as a possibility - the position of distance, the standard precondition for a version of the aesthetic that could, in its withdrawal from the actual, find some means by which the actual could be totalized into a narrative patterned to make typically consistently prevail over the miscellaneous. What national character could never as a point d'appui achieve, racial character might". (DEANE, 1997, p. 110)

* A tradução de todos textos citados foi feita por mim se não houver indicação do tradutor.

${ }^{6}$ Annunciação, Viviane Carvalho da. A pesquisa de Iniciação Científica intitulada Seamus Heaney: Poética do Exílio foi subsidiada pelo CNPq durante a segunda metade de 2003, e pela FAPESP nos anos de 2004 e 2005.
} 
Estados Unidos. Tal trajetória traz em si um movimento ininterrupto de familiarização e desfamiliarização, visto que, embora a experiência do deslocamento tenha produzido muitas dúvidas e desassossegos, o seu retorno é descentrado: além de ele estar em outra parte da Irlanda, e não naquela onde ele nasceu e viveu durante sua juventude Londonderry na Irlanda do Norte - ele ainda absorve as tensões sociais de um país que prospera e pretende apagar seu passado de pobreza e dominação. Sendo assim, podemos enxergar esse problemático retorno como um lugar em que as questões colocadas pela tradição e a experiência de uma vida exilada - com seus sucessos e culpas - produzem uma nova configuração artística.

Ao contrário de uma estética abertamente política, ou então puramente etérea, esse retorno, dramatizado pelo poema "Station Island" (Station Island, 1984), sob o qual iremos nos debruçar ao longo dos capítulos desta dissertação, estaria bastante próximo da conformação cultural que James Joyce apreende em sua Irlanda imaginária, por recuperar certa "hesitação poética de incansável migração"7 (KEARNEY, 1988, p. 110), mas ao mesmo tempo, é pautada em fatos contemporâneos ao poeta. Como advoga Deane:

Havia uma outra posição disponível para a análise cultural: aquela em que se poderia manter a noção de que havia uma tensa e problemática relação de pertencimento ao território nativo, e a capacidade de falar uma língua em que essa ligação pudesse ser articulada. Além do mais, isso também poderia manter a noção de que a tensão entre esses dois poderia representar uma feroz batalha entre inércia e energia, e que o palco desta seria um lugar que era, de alguma forma, não definido. Seria um local crepuscular, ou seja, a posição de exílio, a forma altamente cultural de emigração. Era uma forma de expropriação que mantinha - imaginariamente - a reivindicação à posse, e uma condição em que a modernidade, associada com o novo país em que o exílio nasceu, poderia ser colocada contra a tradição herdada (e opressiva), associada à Irlanda, o lugar que se havia abandonado. Essa era de fato, uma posição ocupada pelos escritores da população local - os dublinenses. ${ }^{8}$ (DEANE, 1997, p. 96).

\footnotetext{
${ }^{7}$ Original: poetic scruple of tireless migration. (KEARNEY, 1988, p. 110)

${ }^{8}$ But there was another position available for cultural analysis. It was one that could retain the notion that there was a tense and problematic relationship between attachment to the native territory and the capacity to speak a language in which attachment to the native territory could be articulated. Moreover, it would also retain the notion that the tension between these could be represented as a fierce battle between inertia and energy and that the site of this battle would always be a place that was in some sense undefined. It would be a crepuscular setting. That was the position of exile, the high cultural form of emigration. It was a form of dispossession that retained - imaginatively - the claim to possession. It was a condition in which modernity, associated with the new country in which the exile was borne, could be played off against inherited (and
} 
Embora Deane use metaforicamente o exílio para se referir ao constante desconforto dos escritores modernistas, acreditamos que essa afirmação possa ser associada à obra de Seamus Heaney. Isso se dá porque o florescer de sua subjetividade artística depende da energia criativa extraída da tradição local, mas é minada pela inércia de sua agência social. Em decorrência dessa estrutura, surge um sentimento de culpa que o atormenta e urge por ser expurgado. Essa purificação é efetivada por meio do alinhamento entre as tradições colocadas pelos poetas irlandeses e aqueles com os quais entra em contato durante o exílio. Mais do que revigorar sua linguagem no intercâmbio cultural com outras formas artísticas, o poeta consegue traçar comparações entre as formas literárias irlandesas e as de outros países de modo a representar, dentro de suas preocupações poéticas, os conflitos históricos de um país cujos habitantes sentem-se exilados, mesmo em suas casas. Há, portanto, uma contínua cadeia de significados sendo reconstruída dentro da forma poética e possibilitando à subjetividade um espaço aberto ao exercício da imaginação.

Segundo Edward Said (2003, p. 47), o exílio, compreendido no seu contexto mais abrangente, "objetiva uma angústia e uma condição que a maioria das pessoas experimenta em primeira mão" ${ }^{9}$, portanto, essa condição leva os exilados à afirmação de que, como Heaney, "nós somos habitantes, nomeadores, amantes, construímos lares e procuramos por nossas histórias" (HEANEY, 1991, p. 131) ${ }^{10}$. A partir dessas características, Heaney absorve as tradições encontradas nos diferentes lugares por onde passa para refletir, de forma contundente, sobre as crises identitárias e políticas da Irlanda do Norte. Assim, como Morris Beja (1992, p. 43) aponta a respeito, novamente, de Joyce, sua "atitude de deixar o lugar de origem não é meramente uma movimentação geográfica. A fuga envolve abandono de tradições e crenças que, em algum outro lugar, são entendidas como mitologias sustentadoras"11, as quais, nesse caso, acabam por serem fragmentadas, e novamente costuradas na óptica da presença-ausência do lar. Além do reconhecimento da ideologia

stifling) tradition, associated with Ireland, the place that had been left. It was, in effect, a position occupied by writers of the town population - Dubliners. (DEANE, 1997, p. 96).

${ }^{9}$ Said desenvolve um panorama de idéias e impressões extremamente consistentes sobre o exílio - tanto de autores ocidentais, como orientais.

${ }^{10}$ Original: "We are dwellers, we are namers, we are lovers, we make homes and search for our histories". (HEANEY, 1991, p. 131)

${ }^{11}$ Embora dedicado a James Joyce, o texto parece explicar muitos dos posicionamentos de Heaney; essa semelhança se dá principalmente porque Joyce é um grande exemplo para o poeta. Original: "the act of leaving one's birthplace is not merely a geographical move... The escape involves abandonment of the very traditions and beliefs which elsewhere are perceived as sustaining mythologies". (BEJA, 1992, p. 43) 
própria de tais mitologias e do envolvimento com as tradições e crenças locais, há poemas como "Summer 1969" (North, 1975) - em que o poeta, por meio de uma cadeia de significação sobreposta, reescreve os conflitos históricos da Irlanda do Norte, na mediação de sua cultura por meio da "descoberta cultural" (HALL, 1999, p. 28) de formas de arte espanholas: a poesia de Garcia Lorca e os quadros de Goya ${ }^{12}$.

Traçar o percurso do exílio foi exatamente o ponto de partida no nosso estudo introdutório sobre a lírica de Heaney ${ }^{13}$. A partir dele, concluímos que o exílio construído por seus poemas estaria mais identificado às tensões psicológicas de uma subjetividade artística conformada - e não conformada - às circunstâncias históricas de sua terra nativa. Ao circunscrever essa inconformidade às obras literárias de outros países e tradições - fato que observamos em poemas como "Serenades" (Wintering Out, 1972), "Fosterage" (North, 1975) e "On the Road" (Station Island, 1984) - o poeta estabelece uma crítica aos atentados terroristas da Irlanda do Norte, oferecendo, simbolicamente, uma alternativa utópica frente à realidade que o oprime, como o faz, por exemplo, ao considerar uma opção válida as propostas pacifistas e comunitárias apresentadas pelos poetas beats americanos. As tensões de identidade dramatizadas pelos poemas também demonstram o quanto a subjetividade do escritor é representante das descontinuidades psíquicas da personalidade pós-moderna, que devido ao "colapso estrutural e institucional das paisagens sociais, fazem com que a identificação, pela qual nos projetamos em nossas identidades culturais" (HALL, 1997, p. 13) seja complexa e problemática. Portanto, essa fragmentação subjetiva estaria imbricada no colapso de um sujeito centralizado e único, visto que, dentro dos sistemas identitários contemporâneos, só são possíveis identidades passageiras e em constante fluxo - como aquelas vistas nos poemas do exílio.

Com a análise arguta de alguns poemas ilustrativos no que concerne à nossa temática, observamos que há uma progressão do desejo de afastamento da terra natal presente na construção do eu poético. Porém, muitas vezes tal desejo é apenas apresentado inconscientemente, e ora abraça uma identidade irlandesa ao se identificar com os sentimentos mais próximos de sua cultura, ora se afasta desta por perceber o quanto tais

\footnotetext{
${ }^{12}$ Para a análise completa de como o poeta reescreve a guerra civil espanhola no confronto civil da Irlanda do Norte, por meio da apropriação de técnicas surrealistas, ver: Annunciação, Viviane Carvalho da. Op. cit., 2004/ 2005.

${ }^{13}$ Iniciação Científica de 2005
} 
valores podem ser, paradoxalmente, manipulados para dispersar discursos construídos socialmente e com intuitos violentos, como guerras civis e atentados terroristas promovidos por grupos sectários. Logo, a configuração subjetiva apresentada não é apenas de alguém dividido entre pertencer ou não a uma comunidade, mas de um artista cuja percepção é que ““esse retorno ao começo' [ou até mesmo a uma cultura pura]... não pode satisfazer um desejo, nem mesmo ser vingado, e, portanto é o começo do simbólico, da representação, da infinita e renovadora fonte dos desejos, memória, mito, procura [e] descoberta" (HALL, 1999, p. 32 $)^{14}$. Heaney, portanto, garante na ausência e falta de referentes culturais, uma presença constante de reconstrução de identidade e criatividade artística.

Entrevemos, assim, um mecanismo de exílio que começa no registro psicológico inconsciente, desprende-se para uma forma artística e ganha contornos realistas com o afastamento geográfico. Por conseguinte, a partir da compreensão do significado dessa movimentação para sua subjetividade artística, Heaney retorna para a Irlanda e recomeça um exílio imaginário - mesmo estando em terras conhecidas - e ciente de que as suas diversas identificações com poetas e artistas de diferentes nacionalidades só puderam garantir identidades e subjetividades múltiplas, que tal como um palimpsesto, são constituídas ao momento da escrita e no seu significado histórico. O deslocamento espacial combinado com a identificação múltipla são reflexos da "possibilidade do devir" (DERRIDA, 1967, p. 84) pós-moderna, em que não há um centro fixo no qual ele se espelha, mas diversos centros que irão atuar em sua constituição e, ao invés de encapsularem a estrutura poética, abrem-na para a aporia de significados. Portanto, a última fase do exílio seria uma nova trama de questões com as quais o poeta deve lidar de modo a continuar fiel ao seu preceito de que a arte deve manter um vínculo formal com a vida concreta. Nessa égide, acreditamos que a poesia de Heaney não consegue se desvencilhar de um cunho utópico próximo ao que Michel Löwy (2005) vê como "principio esperança"15

\footnotetext{
${ }^{14}$ Argumentação de Hall sobre a identidade cultural da pós modernidade. Para ele, uma vez deslocado os valores e percepções iniciais a respeito de uma cultura, não é mais possível o retorno à posição inicial. Original: "'this return to the beginning'... can neither be fulfilled nor requited, and hence is the beginning of the symbolic, of representation, the infinitely renewable source of desire, memory, myth, search... discovery". (HALL, 1999, p. 32)

${ }^{15}$ O filósofo, ao contrário do pessimismo, entrevê um novo Princípio esperança que se forma a partir de movimentos como Fórum Social Mundial, e Movimento pela Justiça Global. Nas suas palavras, deve-se haver o "reconhecimento e respeito das diferenças, que objetiva... um mundo no qual cabem muitos mundos; a emancipação dos seres humanos de todas as formas de opressão, exploração, alienação e degradação; [e] desmercantilização da cultura... seu livre desenvolvimento.(LÖWY,. 2004, p. 35).
} 
da sociedade pós-moderna, em que as diferenças e desigualdades sejam melhores articuladas e resolvidas.

Mais do que lidar com uma configuração social pós-moderna, Heaney redefine também o sentido de lar no momento de seu retorno - ou mesmo de um retorno exilado para a República da Irlanda. Desse modo, a voz poética começa a se aproximar da visão de sujeito cosmopolita, o qual aceita que "You are neither here or there,/ a hurry through which known and strange things pass/ as big buffetings come at the car sideways and catch the heart off guard and blow it open"(HEANEY, 1988, p. 444). O conceito que surge dos versos de seu "Postscript" (The Spirit Level, 1995) é de que o poeta está, de uma forma ou de outra, conformado naquele espaço entre fronteiras que origina "uma consciência de dimensões simultâneas, uma consciência... contrapontística" (SAID, 2003, p. 47) e assume o fato da não existência de um lar físico, ou mesmo transcendental-metafísico. De tal modo, o próprio sentido de lar é esvaziado, e, ao invés de uma preocupação exacerbada com a perpetuação de tradições familiares e folclóricas - como é visto no início de sua obra Heaney começa a compreender a beleza de um cotidiano prosaico, em que surge a valorização das tarefas do cidadão comum.

\section{O POETA "EM CASA"}

Na visão de Terence Brown em Ireland: A Social and Cultural History 1922 - 2002 (BROWN, 2004), a Irlanda das décadas de sessenta e setenta foi marcada pelo que o historiador David Thornley chamou de "pacífica revolução social tardia" (THOENLEY APUD BROWN, p. 231). Essa reforma consistia na mudança de sua paisagem rural e gaélica para um ambiente urbano e industrial, onde ideais sociais e políticos europeus prevaleceriam, fazendo com que fossem aplicados mais investimentos em educação e bem estar público. Desta maneira, a ilha deixaria de figurar o desespero social da "fatiga pósguerra" representados pelos versos pessimistas de "The Sheltered Edge" (MONTAGUE, 1961, p. 32) ${ }^{16}$ escritos por John Montague, e atingiria um estágio essencialmente

\footnotetext{
16 "Standing at the window, I watch the wild green leaves/ Lurch back against the wall, all the branches of the
} appletree/ Stretch tight before the wind, the rain lash/ The evening long again the stubborn buildings/ Raised 
cosmopolita e avançado. De modo a concretizar essa versão de realidade, os esforços do ministro da indústria e comércio do governo De Valera - e, mais tarde, presidente eleito em 1959 - Seán Lemass foram postos em ultrapassar as barreiras unilaterais de comércio com a Inglaterra - o Anglo-Irish Free Trade de 1965 - através da expansão de mercados e, principalmente, de aplicações em fundos para educação primária e secundária.

$\mathrm{Na}$ visão de Declan Kiberd (KIBERD, 1996), tais mudanças entraram em contradição com a noção típica do artista da época:

como uma pessoa em guerra com o consenso social, um cruzado em busca de um ideal que existia mais freqüentemente no passado ou no futuro. Não importa o quão feroz era a crítica feita por um artista, ele ou ela poderia justificar sua crueldade apontando a motivos patrióticos que a circunscreviam $^{17}$. (KIBERD, 1996, p. 580)

Somada ao declínio do modernismo irlandês, e a um processo de independência que havia gerado mais censura, ostracismo e emigração, essa visão acarretava desconfiança por parte do público leitor, que voltava sua atenção aos contos de caubóis vindos dos Estados Unidos. Atraídos pela isenção de impostos proporcionada pelo governo, a grande maioria dos jovens escritores, inspirados pela escrita revolucionária de Beckett, refletiam sobre a experiência alienada do indivíduo. Dentre esses, divididos em elitistas, que tinham seus trabalhos financiados pela agência pública "Aosdána" - "pessoas da arte" em irlandês - e os dissidentes, que criticavam esse assistencialismo público, havia um sintoma de mal estar e ceticismo sobre os novos projetos desenvolvimentistas da época. As vozes que mais se levantaram contra a nova versão da modernidade irlandesa foram as de Thomas Kinsella, Michael Longley, Derek Mahon e Richard Murphy, pois para eles a nova Irlanda seria uma cópia mal acabada da Inglaterra. Não é aleatoriamente que suas maiores influências foram os ingleses do pós-guerra, como Philip Larkin e Wystan Hugh Auden.

Para essa geração, fruto do aumento no consumo de bens culturais, era necessário descobrir uma nação que havia sido silenciada pela dominação inglesa, e reinventar uma

by man, the blackened rubbish dumps, / The half-built flats, the oozing grey cement/ Of hasty walls, the whitefaced children/ Deprived of sun, scurrying with sharp laughter/ From point to point of shelter,/ And arched over all, the indifferent deadening rain". (MONTAGUE 1961, p. 32)

${ }^{17}$ Original: as a person at war with social consensus, a crusader for some ideal which existed more often in the past or in the future. No matter how ferocious the critique mounted by a writer, he or she could always justify that ferocity by pointing to the patriotic motives which underwrote it. (KIBERD, 1996, p. 580) 
cultura que entraria no lugar daquela católica, conservadora e agricultora. Por meio de uma "teoria estética pessoal", as histórias do presente foram recolocadas em pauta. Enquanto Edna Longley, Eiléan Ní Chuillenáin e Eavan Boland discorrem sobre a experiência ignorada da mulher, Seamus Heaney escava as origens da violência do Norte, Derek Mahon e Ciaran Carson redescobrem, no melhor estilo "flanêur", as ruas de Dublin como reflexos de um mundo mais amplo e problemático. Através de sofisticados deslocamentos, essa nova prole de artistas, denominados de Renascença irlandesa, entra no abalo cósmico da desconstrução do familiar, e reinscrevem, nas brechas do presente, o que fora perdido no ciclo evolutivo da história. A nosso ver, essa recuperação de textos, histórias e culturas dispersas pelo caminho é trazida simbolicamente pela palavra grega "omphalos": enquanto para Heaney essa é o cordão umbilical de uma sonoridade basilar, para Nietzsche (NIETZCHE APUD DERRIDA, 1982) ela evoca um espaço discursivo ${ }^{18}$ em que ambos, ouvido e boca, fazem parte do processo de construção de significado. Deste modo, sujeito criador e leitor - na metáfora do ouvido e da boca - reconstroem possibilidades de realidade, em que a literatura intervém de forma decisiva para a formação do indivíduo.

Conjuntamente aos problemas da Irlanda do Norte, essa versão cosmopolita da Irlanda, a qual os autores se voltam de uma maneira participativa, entra em um conflito dicotômico. Enquanto os católicos do sul assumiam uma roupagem moderna e progressista, pensando na Irlanda do Norte como um lugar pré-histórico, habitado por provincianos que insistiam em perpetuar antigas rivalidades, o norte dividia-se em atentados do "Irish Republican Army" (I.R.A.), medo, em virtude da presença da política inglesa, e protestos de uma classe média recém nascida do "Education Act" de 1947. A Associação dos Direitos Civis da Irlanda do Norte (NICRA), inspirada pelos ideais democráticos de Martin Luther King, protestava contra os privilégios do governo inglês sobre Ulster (KIBERD, 1996, p. 573 - 575). Nesse contexto, Heaney é um dos herdeiros desse mesmo ato:

que abre as portas da educação para todos, produzindo uma ascendente e móvel classe média de católicos do norte, capazes de desafiar a hegemonia protestante do Ulster (o 'Ministério do Medo') e também questionar valores

\footnotetext{
${ }^{18}$ Para Derrida, o omphalos de Nietzsche recria uma possibilidade de oto-biography, em que ao mesmo tempo em que o sujeito leitor constrói uma experiência no momento da leitura, ele coloca a sua própria experiência subjetiva no ato. (Derrida, 1982)
} 
tradicionais de família, fazenda e tribo. (KENNEDY-ANDREWS, 2000, pp. $40-1)^{19}$.

Como produto dessa mesma Irlanda dividida em lealdades, decomposta entre antigos mitos nacionais e novas versões de história, o poeta irlandês do norte, no início de sua obra, recorre "às tradições do modo de vida rural, confrontando-o com a moderna experiência urbana e nele procurando uma identidade cultural e um senso de história" $\left(\right.$ VIZIOLI, s/ data) ${ }^{20}$. Tentativa esta cuja essência cria um paradoxo, pois mesmo fundindo as tradições do trabalho familiar na poesia, ele já atesta seu afastamento do grupo pela escolha intelectual. Nas palavras do poeta,

Peter Butter... sugeriu uma bolsa de estudos em Balliol, ou certamente alguma Pós-Graduação em Oxford, e lembro-me de estar desnorteado, e meu pai e minha mãe não tinham a menor idéia daquilo... o mundo para o qual eu estava me direcionando não tinha nenhuma direção para eles. (HEANEY APUD CORCORAN 1961, p. 32) ${ }^{21}$

Se por um lado Heaney recusa-se a lidar com a terra - tradição constante nas gerações anteriores - por outro lado, começa cada vez mais se identificar com a comunidade de onde vem, na medida em que os poemas do "bog" (pântano) estabelecem “"uma tentativa de ligar, de maneira simbólica e Jungiana', o pântano 'como repositório da memória da terra, à psique das pessoas"” (HEANEY APUD O’BRIEN, 2002, p. 16) ${ }^{22}$. Há, deste modo, um movimento complexo atuando nas camadas de significado entre o "eu" e o "nós", pois mesmo trabalhando com temas caros à poesia, como a terra, a religiosidade, a sexualidade, a violência, a história e o mito, essa mesma sociedade é observada de modo desconfiado pelo poeta, reflexo das preocupações desse novo grupo de artistas.

\footnotetext{
${ }^{19}$ Original: "Heaney was one of many beneficiaries of the 1947 Education Act, which opened up secondary education to all, and produced an emergent, upwardly mobile class of middle-class Northern Catholics capable of challenging the Ulster Protestant hegemony (the "Ministry of Fear) as well as question the traditional values of family, the farm, the tribe". (KENNEDY-ANDREWS, 2000, pp. 40-1)

${ }^{20}$ Consistente argumentação em que o crítico brasileiro expõe, em ordem cronológica, as principais temáticas da obra de Seamus Heaney. (VIZIOLI, s/ data)

${ }^{21}$ Original: "Peter Butter... suggested a studentship at Balliol, or certainly some graduate work at Oxford, and I remember just being bewildered, and my father and mother had absolutely no sense of that... the world I was moving in didn't have any direction for them".

${ }^{22}$ Original: "'an attempt to link, in a symbolic Jungian way' the bog as the 'repository and memory of the landscape, with the psyche of the people". Trecho retirado do estudo de Eugene O'Brien sobre a poesia de Heaney, em que ele observa uma ligação psíquica do percurso poético de Heaney e o trajeto histórico da Irlanda.
} 
Um dos fatores que revela essa intricada relação entre Heaney e a sua terra de origem estaria relacionado ao modo como ele ingressa na carreira acadêmica e nas reuniões de intelectuais feitas na Queen's University de Belfast em 1963. Participando do grupo chamado "The Belfast Group" que era presidido pelo crítico e poeta Philip Hobsbaum, cuja teoria crítica ajudou a consolidar a imagem da poesia do Norte ao desafiar os credos e pretensões de novos poetas, Heaney começa a, efetivamente, desenvolver sua carreira artística. Hobsbaum, influenciado pelo fundador do "New Criticism", F. R. Leavis, que foi igualmente seu professor em Cambridge, ressalta a importância do texto e da forma lingüística na análise literária e como esses desenvolvem posicionamentos de ordem ética e moral (HOBSBAUM APUD CAMBRIDGE, 2002) 23. Aliado ao comprometimento metodológico, o professor não deixava de exigir um constante trabalho criativo de seus alunos pois, após o exame detalhado da obra um autor específico, eles eram requisitados a recitar seus próprios poemas. Após a partida de Hobsbaum em 1966, Heaney assume a liderança dos encontros; anos depois, divide a tarefa com Arthur Terry e Michael Allen (PAKENHAM, 1976, p. 58).

Do constante exercício prático e convívio intelectual, Heaney entra em contato com os poetas Michael Longley e Derek Mahon (que declara não entender as opiniões de Hobsbaum), e os críticos Edna Longley, Seamus Deane e Stuart Parker. Organizados em torno de revistas como Gorgon e Interest, a produção do grupo consistia na redefinição de padrões estéticos clássicos, que seriam mais uma vez retificados com a eclosão dos conflitos civis. Sobre suas descobertas iniciais Heaney afirma:

todos nós no grupo nos referíamos a autores ingleses da década de cinqüenta e sessenta... Em 1962... escrevi um trabalho sobre a história de revistas literárias no Ulster, como se eu já estivesse procurando uma base para a fé na experiência cultural do norte, como irlandês, e como nós mesmos. (HEANEY APUD LONGLEY, 1994, p. 51) ${ }^{24}$.

\footnotetext{
${ }^{23}$ Dentre as características mais importantes do legado de F. R. Leavis, Hobsbaum destaca: "attention to the text. And great attention to the linguistic properties of the text, the way words interact. And also a kind of moral stand. People often said that Leavis is vague politically; that shows they don't know politics. The key to a lot of Leavis's thinking is in the introduction to his edition of the two essays by John Stuart Mill on Bentham and Coleridge. He there comes out very strongly as an old radical liberal; a left wing liberal". (HOBSBAUM APUD CAMBRIDGE, 2002)

${ }^{24}$ Panorama delineado pela crítica Edna Longley. Original: "All of us in the group were harking to writers from the English cultural background of the late fifties and sixties... In 1962... I had done an extended essay on the history of literary magazines in Ulster as though I were already seeking a basis for faith in the
} 
Sendo assim, entrevemos que há já uma dialética operando na mente de tais artistas, ou seja, ao mesmo tempo em que eles estudam e compreendem o cânone inglês, eles o moldam à experiência do Norte. Desse movimento acadêmico, surge na década de sessenta e oitenta a Field Day Anthology of Irish Writing, em que as descobertas estéticas, caminham para uma intervenção mais propriamente política.

As transformações nos rumos artísticos do grupo estavam relacionadas à eclosão das marchas pelos direitos civis dos católicos do Norte (NICRA), que foram compreendidas pelas autoridades britânicas como uma nova tentativa de separação. De acordo com José Antonio Arantes:

no final da década de 60, novos acontecimentos dramáticos na Irlanda do Norte viriam agravar um dilema ético. Em 1968 -9, a repressão ao movimento católico de direitos civis reacendeu o conflito na Irlanda do Norte, o início do que se chamava de 'troubles'. O governo britânico ocupou Derry e Belfast com um grande contingente de soldados introduziu os internamentos e os campos de detenção. E com uma eficiência e rapidez tais que, no final de 1971, cerca de 1600 pessoas foram presas sem direito a julgamento. (ARANTES, 1998, p. 21).

É neste período que Heaney recebe gratificações importantes para sua carreira literária: o prêmio “Somerset Maugham”, uma cadeira na Queen's University de Belfast e o lançamento de seus primeiros livros. Nesse contexto histórico-cultural, Heaney, como poeta e intelectual, começa a refletir sobre uma arte que não seja panfletária, mas que consiga levar em consideração o momento histórico do qual faz parte. Seria como um realinhamento de relações em que a subjetividade poética procura um ponto de apoio para reorganizar suas leis internas, sem se deixar levar por nacionalismos exacerbados: daí surge o reconhecimento de que o exílio geográfico é imprescindível.

De modo à re-significar a história da Irlanda do Norte a partir de mitologias deslocadas, como as dos vikings e as nórdicas, Heaney encontra uma identidade poética conectada à psique popular, ao iniciar uma jornada de volta às memórias pré-históricas de sua terra de origem, conectando a violência do passado à do presente, por meio das imagens das turfeiras e dos hábitos de vida primitivos, que remetem aos sacrifícios provindos da Era de Ferro. No livro

possibility of our cultural experiences as northern, Irish and essentially, ourselves". (HEANEY APUD LONGLEY, 1994, p. 51) 
Door into the Dark (1969), em cujas páginas Heaney, não mais preso exclusivamente às lembranças pessoais, se desloca para fora de si mesmo, ocupando-se também dos ciclos da natureza, que detecta nas diferentes camadas das turfeiras irlandesas... em Wintering Out (1972) ele amplia esses ciclos para que abranjam igualmente o passado remoto do homem, numa viagem à pré-história. (VIZIOLI, s/ data)

Concluímos, então, que o poeta transpõe camadas particulares para se aproximar de uma arte cujo ponto de partida seja o olhar para o passado a partir de um ponto de vista social e exilado. Esta atinge, no presente, seu ponto culminante em North (1975): a "primeira parte... pode ser chamada de histórica - visto tratar das invasões sofridas pela Irlanda desde os vikings... [e] uma segunda..., de sabor coloquial... que trata dos acontecimentos recentes no Ulster" (VIZIOLI). Essa análise artística e histórica da memória popular contida na coletividade da terra - conceito Benjaminiano em que "Erinnern, recobra a interioridade oculta da terra, Erdinnern, desprendendo-se de (ausbrechen) toda interioridade" (BENJAMIN APUD COMAY, 1994, pp. 263-4) ${ }^{25}$ traz conhecimento sobre a própria realidade cultural do poeta. A memória histórica apaga uma vivência individual e a recoloca na experiência da nação.

Após esse grande prelúdio de quatro livros para uma obra extremamente rica e complexa, entendemos que o poeta sente a necessidade de se desvincular tanto das tradições familiares, quanto dos posicionamentos de sua comunidade, visto que em meio a um período de guerra civil e nacionalismos extremamente exaltados, seria difícil não ceder às pressões públicas. Sua saída da Irlanda do Norte é, portanto, fruto de um exame histórico e cultural cuja conclusão é apresentada pela coleção de seis poemas chamada "Singing School" (North, 1975), em que o "eu poético", influenciado pelas mais diversas fontes artísticas - literatura, teatro, pintura, música - ressalta o quão impreterível é a atitude de deslocamento para o seu trabalho. A atitude psíquica de afastamento é, assim, transposta à prática e Heaney começa a compreender que o dom da poesia "é dizer a verdade, mas dizê-

\footnotetext{
${ }^{25} \mathrm{O}$ conceito de Walter Benjamin sobre memória torna-se adequado a Heaney, pois ele correlaciona a experiência geográfica e história à questão da subjetividade. Logo, a memória é uma constante escavação, como o próprio poeta atesta em seu primeiro poema: "Digging". Outro sentido da memória recuperado pelo filósofo é a constante junção de fragmentos dispersos, questão essa com a qual Heaney também se depara no seu artigo sobre Osip Mendelstam. Para o poeta, cada parte da memória recuperada pelo artista russo, também recobra a memória da nação e de sua história propriamente dita. Essa semelhança de conceitos se dá, provavelmente, pela leitura que ambos fazem da dialética hegeliana - o microcosmo que é ilustrativo do macrocosmo, ou então a parte que explica o todo. (BENJAMIN APUD COMAY, 1994, p. 263, 264).
} 
la de viés, isto é, ao mesmo tempo irrefutável e transformador" (HEANEY, 1998, p. 454). Um dos aspectos desse viés será o encontro cultural com a arte das nações por onde ele passa e a comparação de circunstâncias históricas alheias que servem de contraponto para seu contexto histórico. Um exemplo é o poema "Fosterage" (North, 1975) em que a voz poética pondera sua arte à luz da arte de Katherine Mansfield e Gerard Manely Hopkins, ressaltando o quanto o exílio da neozelandesa, contribuiu para ele compreender seu próprio exílio em uma linguagem imposta pelo domínio colonial inglês - o que o faz conscientemente retomar o estilo sonoro de Hopkins.

Com o afastamento concretizado, o poeta, em “Field Work (1979)... dá a impressão de estar batendo em retirada, pois busca conscientemente refúgio (numa espécie de 'fuga ao massacre') nos recantos bucólicos do sul da Irlanda" (VIZIOLI). Sem demasiadas surpresas, essa decisão confere a Heaney a imagem de traidor não só por parte das alas mais radicalmente nacionalistas, como as do I.R.A., mas também dos simpatizantes do Unionismo. Segundo Heaney, essa atitude significa um momento de meditação, visto que ele precisou "construir um abrigo dentro de [si] mesmo onde os poemas continuassem sendo poemas" (HEANEY APUD BARROSO, s/ data) ${ }^{26}$, ou seja, precisou afastar-se da euforia típica das revoluções e, a partir da sua arte, pensar sobre os desdobramentos da guerra. Com base no que o próprio poeta diz, esse afastamento, ao invés de causar somente alienação e introspecção, produz também o efeito contrário. Ao passo que ao avaliar seu papel social, ele abre, cada vez mais, seu campo de visão para artistas que não são da tradição anglo-irlandesa. A recriação de formas mais convencionais, como a elegia e o soneto, demonstra igualmente, a procura por uma voz própria, a qual deseja uma identidade singular - mesmo que ainda relacionada aos assuntos políticos e ideológicos de seu país.

\section{A MUdANÇA NO RETORNO}

De acordo com Arantes (1998, p. 23):

a partir de Station Island (1984)... [os poemas de] How Lantern (1987), Seeing things (1991) e The Spirit Level (1996)... consistem [uma] espécie de

\footnotetext{
${ }^{26}$ Ivo Barroso ressalta a importância da poesia de Seamus Heaney. Texto escrito no período em que ele ganha o prêmio Nobel de Literatura. (HEANEY APUD BARROSO, s/ data)
} 
re-visitação da trajetória circular sob orientação do guia Dante, mas a partir da visão de um 'eu' maduro e desembaraçado que, pelo 'nível de bolha' (o spirit level) do fazer poético verifica o equilíbrio entre o plano real e o imaginário e ao mesmo tempo toca os limites das reminiscências dos primeiros livros... Como resumiu... J. W. Foster, Heaney aprofundou mais ainda os elementos característicos de sua poesia com a descoberta dos povos de turfeira; mas agora passa a vê-los não através da terra ou das trevas, mas através do ar e da luz.

Além da revisão de sua poesia a partir do olhar de Dante, também acrescentamos que a busca de uma poesia que harmonize planos reais e imaginários se dá por meio da imagem do pássaro Sweeney. Seria como se, a partir da lenda de Sweeney, que conta a história de um rei que fora transformado em ave por suas transgressões, o poeta quisesse enxergar o mundo com novos olhos: não como uma vítima, mas alguém que sofre constantes transformações e ganha novas formas de olhar sua cultura. Isso se dá muito provavelmente porque o pássaro é seu alter ego e procura, noutros lugares, formas de expurgar a sua culpa por ter transgredido a norma social. Além do mais, em outros espaços, ambos reconhecem novas trocas culturais.

Sobre a questão da transposição da tonalidade terra para o ar, o crítico literário e tradutor Rui Carvalho Homem defende que existe um lento movimento no trabalho de Heaney que o faz chegar a tal ponto. Uma das razões para isso é o seu amadurecimento artístico combinado com essa nova experiência. Citando o poeta, ele afirma:

Heaney próprio reconheceu uma mudança em seu ponto de vista e ambições poéticas, a qual ele caracterizou como um interesse crescente 'na poesia da claridade e do fraseado comum', 'uma poesia da janela de vidro', ao invés da 'do vidro manchado'. Ele, mais para frente, declarou sua crença 'que os prazeres da própria linguagem e a brincadeira de inventar e a simplicidade de obedecer às suas vontades e impulsos são suficientes para prosseguir'. Na mesma ocasião, Heaney associou a mudança em sua escrita, por um lado, a 'um leve senso de lugubridade e vivacidade' derivado de 'voar para lá e para cá através do Atlântico', e por outro lado, 'a experiência de ficar um pouco mais velho'. (HOMEM, 1999, p. 29) ${ }^{27}$.

\footnotetext{
27 Original: "Heaney himself acknowledged a change in his outlook and his poetic ambitions which he characterized as a growing interest in 'the poetry of clarity and plain statement', 'a poetry of window glass' rather than of 'stained glass'. He further stated his belief 'that the pleasures of the language itself and the sportiveness of inventing and just the simplicity of being whatever your volitions and impulses are - that they're enough to be going with'. On the same occasion, Heaney associated the change in his writing with, on the one hand, 'a slight sense of eeriness and airiness' derived from 'flying on aeroplanes back and for the Atlantic'; and on the other hand, the experience of 'getting a bit older'”. (HOMEM, 1999, p. 29)
} 
Em sua declaração, o poeta atesta que a experiência do exílio, ou mesmo dos deslocamentos geográficos, proporcionou uma expansão de visão e uma transformação em sua arte. Contudo, essa transição, como o próprio crítico afirma, é de fato, uma consciente e preparada transição, que se desenvolve ao longo de seus livros.

De acordo com Homem (1999, p. 30), a transformação poética de Heaney acontece quando a realidade "se apodera da forma dos momentos evanescentes de iluminação, ou da experiência de ser traduzido da dimensão material e da existência objetiva [e é transformada naquela] do ser insubstancial e do espaço ilimitado ${ }^{\text {"28 }}$. Entretanto, o poeta aceita essa fluidez espacial como uma necessidade de re-ligação com a terra natal, pois decide revisitar os espaços deixados para trás durante o exílio. Assim sendo, após a decisiva publicação de Sweeney Astray (1982) - tradução do poema medieval Buile Suibhne - o poeta começa a voltar seus olhos para si mesmo e a procurar, no encanto com as palavras, ou até mesmo na "auditory imagination", algo que o conecte mais intimamente com a sua comunidade, mesmo que o significado de lar tenha sido disperso ao longo de suas estadias em lugares estranhos e distintos. Essa ligação começa, então, a ser alcançada com a procura do lar por entre as atividades cotidianas, e a novidade que delas brota no olhar "enviesado" e intertextual. Através da dessacralização dos clássicos ao representar vida simples das pessoas - e de seu próprio dia-a-dia - Heaney consegue uma tranqüilidade poética para retratar sua comunidade e valorizar mesmo os aspectos mais prosaicos de uma Irlanda, cujas características modernas não deixam de conviver com as singularidades provincianas, e também com a iminente possibilidade da violência.

Insistimos ainda na importância da tradução de Sweeney Astray (1982) como um dos pontos significantes de sua transição, pois a despersonificação do Rei da Irlanda, que fora condenado a percorrer sua terra como um pássaro, faz com que o poeta compreenda os aspectos mais simples de seu povo e o ajude também a parar de "lamber suas feridas", curando-as de uma maneira definitiva. Esse é o tema da versão Cure at Troy (1990), da peça Philoctetes do dramaturgo grego Sófocles, em que, por meio de um viés clássico e distanciado, o poeta consegue representar as tensões sectárias, e por vezes, ressentidas, de

\footnotetext{
${ }^{28}$ Original: "Take the form of evanescent moments of illumination, or the experience of being translated from the dimension of material and objective existence into that insubstantial being and unlimited space". (HOMEM, 1999, p. 29)
} 
seu lugar de origem. Entretanto, as imagens de pássaro na obra de Heaney, não têm início em 1982, mas dez anos antes em "Serenades" do livro Wintering Out (1972). No poema, ele chama atenção para a importância da atitude de exílio e demonstra as contradições encontradas nas práticas políticas agressivas de grupos opositores e explicita sua vontade de ausentar-se de toda pressão por parte da mídia para que os artistas assumissem uma posição pública. Com Sweeney, a voz poética se desprende dessa cápsula realista - e muitas vezes maniqueísta - dos conflitos sociais e começa a se voltar àquelas pessoas comuns que estão muitas vezes "no meio" desses conflitos.

Empregamos o termo "no meio" pois desejamos argumentar, de acordo com Fintan O’Toole que, nos dias de hoje, há uma configuração muito peculiar na Irlanda. Se por um lado sua história pode ser lida e compreendida, por outro, esta é uma ilha que, demograficamente, deve ser escrita porque permanece constantemente aberta ao exercício da imaginação e criatividade, pois muito da sua apreensão provém de comunidades diaspóricas. Desta maneira, as formulações do crítico nos levam a compreender que há um espaço entreaberto de transição na vida dos cidadãos irlandeses. Segundo o crítico:

há agora uma nova zona, ao mesmo tempo cultural e geográfica, que não pertence ao centro, nem à margem, e grande parte da Irlanda pertence a ela. O poeta australiano Les Murray defende que a verdadeira margem não está agora nas extremidades, mas no centro. De um lado está o centro metropolitano, e de outro, aquilo que Murray chama de meta-margem. E alguns aspectos da cultura Irlandesa - aqueles que eram realmente marginais por todo século dezenove - agora pertencem claramente à meta-margem. (O’TOOLE, 1997, p. 159) ${ }^{29}$.

Deslocado entre o centro e a margem, refletindo sobre os cidadãos comuns, concomitantemente, destituído de um lugar fixo de representação e de lar, a transição de Heaney, portanto, espelharia essa característica da meta-margem.

\footnotetext{
${ }^{29}$ Fintam O' Toole, importante historiador e jornalista irlandês, aborda a história da Irlanda baseado no conceito de identidade e globalização. Os aspectos econômicos também exercem uma enorme influência de sua crítica, porque ele compreende a passagem de um lugar de margem para um "entre lugar", que pode ser essa posição ambígua do país: um legado de violência e dominação, e um presente de avanços econômicos e alvo de grande interesse cultural. Original: "There is now a zone, at once cultural and geographical, that belongs neither to the margin nor centre, and much of Ireland belongs in it. The Australian poet Les Murray has argued that the true margin is now not on the outer edge but in the middle. It lies between the metropolitan centre, on the one side, and what Murry calls the meta-margin, on the other. The latter zone is the 'the exotic, the wilderness, the vanishing archaic'. And certain aspects of Irish culture - those that were truly marginal for most of the nineteenth century - now belong clearly to the meta-margin". (O'TOOLE, 1997, p. 159)
} 
No momento em que o poeta decide re-imaginar seu lugar de origem ao re-significar e re-inventar os paradigmas de sua poesia, ele está, de fato, transpondo à sua poesia uma nova ordem social de seu lugar de origem, cujas mitologias de sustentação e história oficial fazem parte de um passado. No entanto, o lugar que a voz poética deseja ocupar agora é o ar, ou seja, um espaço de transição e confluências que pode ser constantemente mudado, ao contrário das políticas binárias e sectárias do governo norte irlandês e das alas mais radicais do exército republicano irlandês (I.R.A.). Essa liberdade cultural possibilita que Heaney observe mais detalhadamente os cidadãos e tente, de viés, fazer com que eles pensem mais sobre sua sociedade e mudem o que está em desacordo. Parece ser esse o intuito, novamente, das peças Cure at Troy (1990) e Burial at Thebes (2004), cujos temas, apesar de corresponderem à situação da Irlanda do Norte - onde há uma fratura exposta e corrosiva, alimentada por posições fundamentalistas e fixas como as de Odisseu e Philoctetes, ou Creonte e Antígone - podem ecoar a própria situação do mundo contemporâneo dominado por incompreensão e intolerância. Mesmo que não atinja uma grande parte da população, o trabalho do poeta caminha formando leitores críticos e socialmente conscientes de sua história. Sendo assim, essa formação está de acordo com o sentido que o crítico brasileiro Antonio Candido confere à palavra formação, com relação à função social da literatura.

Através da "revisitação" de sua poesia e metamorfoseado na figura de Sweeney, o poeta estará articulando discursos de artistas diversos que servem para moldar uma nova identidade, constantemente em transição. Como ele atesta em seu discurso ao Nobel:

'a história de São Kevin' - aquele que permaneceu em atitude de oração, no momento em que um pássaro fez ninho em suas mãos - 'é, eu diria, uma história da Irlanda. Mas o interessante é que esta poderia vir tanto da Índia, ou da África ou do Ártico ou das Américas. Eu não pretendo configurar essa lenda em uma tipologia de contos folclóricos ... mas [garantir que] sua fidelidade e seu valor migratório (travel-worthiness) estaria relacionado ao local em que ela acontece, ${ }^{30}$ (HEANEY, 1998, p. 454).

\footnotetext{
${ }^{30}$ Original: "St. Kevin's story is, as I say, a story out of Ireland. But it strikes me that it could equally well come out of India or Africa or the Arctic or the Americas. By which I do not mean merely to consign it to a typology of folktales... its trustworthiness and its travel-worthiness have to do with its local setting". (HEANEY, 1998, p. 454)
} 
Assim, a credibilidade do trabalho do autor se dá pelo fato de ele colocar em nível global e mundial, valores que são aplicados em seu universo pessoal e doméstico, conferindo um intercâmbio de estórias e histórias que, em si mesmas, já carregam uma grande relevância social.

O caráter migratório da sua poesia, a questão da terra que se volta para o ar, ou até mesmo o olhar extremamente apegado com as preocupações políticas, desviando seu foco para a pessoa comum, está também relacionado a uma circunstância cultural da sociedade Irlandesa: a fratura da partilha entre Irlanda do Norte e República da Irlanda. De acordo com Joe Cleary:

Na República da Irlanda, era sentida uma necessidade de uma nova literatura escrita em língua inglesa, como os Estados Unidos já haviam feito. O novo estabelecimento do Norte, no entanto, era mais ansioso para enfatizar as conexões que o Estado tinha com a Inglaterra, ao invés de se distanciar dela. (CLEARY, 2004, p. 263).

Ciente de uma tradição cultural ambígua e plural, Heaney não aceita passivamente essa dominação Britânica e, no cerne de sua produção artística está uma forma de resistência que "reconhece e representa diferentes lealdades... a que o vincula a[os]... direitos cívicos da (sua) minoria católica na Irlanda do Norte; e... a lealdade poética que desde cedo afirmou uma vontade de não-enfrentamento a causas públicas" (HOMEM, 1997, p. 17). Se Heaney por um lado, no início de seu trabalho, está mais voltado à questão de como pode transpor, ou até mesmo re-significar e re-inventar os valores de sua comunidade, por outro, após o período de exílio e transição, essa tensão entre lealdades começa a ser problematizada pelo olhar do pássaro mitológico Sweeney. Esse não apresentará uma visão apenas etérea, pois mesmo voando ele ainda volta seus olhos para a terra; contudo, não mais restrita e opressora, mas ampla e plural.

A força de uma estética do cotidiano, que se preocupa com as questões mais simples e ordinárias de sua comunidade, estaria igualmente articulada ao mecanismo de exílio, o qual gera uma polifonia poética - ou até mesmo a consciência do intercâmbio de estórias e culturas. No momento da saída de Derry - lugar onde a sua subjetividade se forma e as tradições familiares se estabelecem - o artista, como um compositor de melodias dissonantes, orquestra elementos formais de escritores mundialmente conhecidos, com os de sua nação. Com o intuito de inserir seu trabalho no cânone literário, ele chama a atenção 
de leitores a autores irlandeses que, devido às armas imperialistas foram excluídos de uma análise mais arguta e cuidadosa, pois "muito raramente admite-se que o povo colonizado deve ser ouvido e suas idéias conhecidas" (SAID, 1999, p. 86) ${ }^{31}$. Ao trabalhar nessa consciência contrapontística (SAID, 2003), a qual o possibilita resistir ao domínio inglês com suas narrativas próprias e apropriar-se da literatura que o domina, o poeta insere sua arte no domínio da literatura cosmopolita, criando uma força de resistência perante o discurso dominante e unilateral.

Sobre o tema do alcance da resistência da obra de Seamus Heaney, muita controvérsia foi provocada. A crítica literária Fran Bearton (BEARTON, 2003) ) $^{32}$, que observa a poesia do Norte da Irlanda com base nos motivos criados pela Primeira Guerra Mundial, chega à conclusão de que Heaney não estabelece vínculo com sua comunidade. Para ela, as imagens e alegorias de seus poemas criam apenas um fraco pretexto para que ele possa escrever poesia e se deleitar com a beleza que essa traz mesmo em momentos difíceis da história irlandesa. Contudo, se por um lado ela apóia seu estudo em críticos materialistas como Fredric Jameson, dentre outros, ela ignora a dialética que eles próprios propõem, e que é, ao nosso ver, levada a condições extremas por Heaney, sendo que ele mesmo afirma ser dialético. Portanto, os argumentos da autora tornam-se superficiais, pois Heaney liga-se à Irlanda do Norte, à medida que sua subjetividade é constituída a partir de um desejo de conectar-se com a terra natal e sua comunidade. Contudo, esse desejo não pode ser realizado por circunstâncias históricas - ataques terroristas, identidade ambígua, linguagem imposta. Todos esses motivos fazem com que ele seja socialmente mediado pela história e artisticamente moldado pela herança cultural da Irlanda. Portanto, assim como Adorno critica Brecht por sua simplicidade estética, e valoriza Beckett por sua complicação estrutural que carrega uma força de resistência (ADORNO, s/ data) ${ }^{33}$, é interessante

\footnotetext{
31 Estudo pioneiro de Edward Said sobre a questão de como o tema do imperialismo penetra, inconscientemente, em diferentes obras literárias inglesas e de suas colônias. Ao longo dos capítulos, o autor propõe leituras distintivas das obras imortalizadas pelo cânone inglês, como Heart of Darkness, Kim e a poesia política de Yeats. Embora os estudos pós-coloniais tenham avançado, as idéias de Said continuam a serem extremamente relevantes. (SAID, 1999, p. 86)

${ }^{32}$ Estudo no qual a autora, após examinar grande parte da lírica irlandesa, chega à conclusão de que Michael Longley é o grande poeta que reflete os problemas do Norte da Irlanda. Visão um pouco reducionista por vincular a importância de determinado autor à forma pela qual ele aborda a questão da Primeira Grande Guerra. Em todo estudo, a crítica parece esquecer do fato que a Segunda Guerra mundial também atingiu a Irlanda e mudou sua trajetória, como a do resto do mundo. (BEARTON, 2003)

${ }_{33}$ Adorno traça um paralelo entre as artes engajadas na França e na Alemanha e conclui que a arte não precisa ser abertamente engajada, porque na sua dialética entre forma e conteúdo, ela consegue transmitir as questões
} 
compreender como, na dialética do pertencer e não-pertencer, a poética de Heaney engendra quebras, empréstimos e intertextualidade que resiste a uma configuração simplista de história.

Outro crítico que faz uma série de comentários ressaltando a natureza etérea e alienada da obra de Seamus Heaney é Peter McDonald ${ }^{34}$. Se por um lado Bearton afirma que Heaney é um poeta apenas esteticista, por outro, McDonald leva essas afirmações para um lado puramente formal e, reduzindo esse estruturalismo complexo, chega a afirmar que Heaney simplifica os intricados experimentos técnicos de Yeats e não consegue avançar para além disso. Por se deter em uma leitura próxima da Nova Crítica americana, o autor não consegue compreender que a estrutura formal do poeta é uma questão histórica também, pois ela demonstra o modo como o artista compreende e representa a realidade por ele observada. Além do mais, ambas as posições, apesar de serem contrárias teoricamente, chegam à mesma conclusão, ou seja, uma idéia simplista de que a subjetividade artística de Heaney seria apenas um construto interessado em embelezar o mundo em tempos difíceis. Enquanto esse tipo de leitura tende a diminuir a importância do poeta em diferentes correntes literárias, acreditamos que a combinação de história e forma artística - como Antonio Candido reitera em O Estudo Analítico do Poema (2004) e no qual baseamos nosso experimento cognitivo - produz uma leitura muito mais problemática e reveladora em relação à sociedade e à arte que ele cria.

Contra essas posições, a crítica de Terence Brown (1992) $)^{35}$ parece ser a mais abrangente, principalmente porque a liberdade com que Heaney parece escrever, e sua aparente despreocupação com o social - na fase artística após Station Island - estão relacionadas à sua capacidade de aceitar a opinião pública e não desviar o olhar daquele que exige dele uma posição solidária. Para o historiador, a culpa que ele sente por ser poeta

mais imediatas da sociedade. A imagem final é a do Angelus Novus de Paul Klee em que o anjo, mais do que dar, toma para si as catástrofes do passado. Desta mesma maneira funciona a arte, por meio de sua forma, ela carrega as tensões históricas e sociais ao longo do tempo. Adorno, T. s/d: pp. $28-37$

${ }^{34}$ Livro de Peter McDonald é uma obra de análise que leva em considerações questões ditas universais em poesia e que afetam diretamente a escrita na Irlanda, principalmente aquela produzida por William Butler Yeats e os poetas do Norte, como Seamus Heaney, Derek Mahon, Michael Longley e Tom Paulin. Talvez o maior problema do livro seja não passar da arte para a história e, por conseguinte, ao mundo de onde o poeta escreve. (MCDONALD, 2002)

${ }^{35}$ Terrence Brown defende que a validade da poesia de Heaney está no fato de ela ser um testemunho. Sendo assim, sua experiência fala através dos poemas - ambas as categorias são mediadas socialmente. (BROWN, 1992) 
retorna à forma artística e, produzindo um sentimento de libertação, confere uma força criativa à sua poética. Nesse sentido, a linguagem parte de uma busca por respostas a anseios imediatos, para uma reflexão maior, que não precisa tratar de assuntos pontuais. Contudo, isso não significa que sua poesia mais recente não seja de relevância social. De uma posição de observador, Heaney se transforma em testemunha que fala livremente sobre o que viu e viveu, assumindo uma visão mais madura e consciente. Outra posição que se direciona às mesmas conclusões chegadas por nosso trabalho, é a da escritora e crítica literária Edna Longley, pois ela compreende a poesia não só de Heaney, mas também de uma tradição recente do Norte, como a constante reformulação da tradição e reafirmação da identidade irlandesa.

No relato sobre a sua experiência de analisar a intertextualidade que encontra nos poetas do norte, Longley afirma:

tradição é mais do que a soma de talentos individuais, ela opera tanto a curto, quanto a longo prazo... [é] uma rede textual [em] que o termo intertextualidade, era aplicado a poesia norte irlandesa de uma forma especial e viva: não como uma teoria morta, mas como um trabalho criativo que opera de modo semelhante nos mecanismos de tradição e definições culturais. Os diálogos intertextuais podem ser explícitas variações de um tema. (LONGLEY, 1994, p. 51) ${ }^{36}$.

Esse apontamento, que funciona perfeitamente na obra de Heaney, faz-nos tentar compreender como essa "rede textual", da qual Longley fala, opera nos poemas trazendo uma força de resistência, e criando um cruzamento entre autores de posicionamentos diferentes, mas que encontram, por meio da escrita poética uma força perante momentos históricos opressores. Além do mais, ao articular diversos textos na sua poesia, Heaney valida uma abertura de consciência que foi reprimida pela dominação britânica.

\footnotetext{
${ }^{36}$ Edna Longley observa a variedade de características e temáticas que a poesia norte irlandesa apresenta desde o processo de independência até os dias atuais. Sem os critérios literários, a autora faz uma importante conexão entre literatura e história. Original: "Tradition is more than the sum of individual talents and it operates in the short term as well as the long... I found that I was often tracing a textual web, and that the term "intertextuality" applied to Northern Irish poetry in a special, living sense: not was a theoretical dead letter, but as a creative dynamic working upon mechanisms of tradition and cultural definitions alike. Intertextual dialogues may be explicit variations on a theme". (LONGLEY, 1994, p. 51)
} 


\section{O EXÍLIO TORNA-SE POLIFÔNICO, OU A POLIFONIA TORNA-SE EXILADA?:}

\section{A ProblematizaÇÃo DA TEMÁtiCA DO EXílio À LUZ DA INTERTEXTUALIDADE}

Se considerarmos que, de acordo com Mikhail Bakhtin, o "romance polifônico" apresenta uma essência dialógica e múltipla, esse conceito pode ser aplicado à poesia de Heaney para explicar como os sujeitos por ele representados se desprendem de um caráter essencialmente ideológico e se constituem textualmente na realização do poema. Para analisar o diálogo com outros escritores canônicos, dentro e fora da tradição irlandesa, o conceito de "intertextualidade" elaborado por Julia Kristeva, torna-se uma ferramenta para, dentro do contexto do poeta, descrever como essa consciência polifônica "se insere no conjunto dos textos". Para ela "o texto literário é uma rede de interconexões, que, pelo seu modo de escrever, lendo o corpus literário anterior ou sincrônico, o autor vive na história e a sociedade se escreve no texto. A ciência pragmática é um diálogo de dois discursos" (NITRINI, 2000, p. 162) ${ }^{37}$, fazendo, assim, com que dentro do espaço discursivo, haja um sistema de textos lidos pelo autor. A partir da ótica de Kristeva, poderemos compreender melhor como o poeta articula essa sinfonia de textos em sua poesia e descobrir que efeitos isso causa no leitor e na sociedade, ora acolhendo sua obra, ora produzindo outros textos a partir de suas idéias e questionamentos.

Visto que no cerne do texto literário há um diálogo de ambivalência, onde a palavra, em nível horizontal, pertence ao sujeito da escritura e seu destinatário, e em nível vertical, direciona o sujeito para o corpus literário anterior, representado pela história e sociedade, necessitamos compreender o contexto histórico e cultural de Seamus Heaney, que é permeado por tensões. Quando o poeta decide deixar Derry, há uma redefinição de mitologias e imagens, o que marca profundamente seu trabalho, uma vez que a partida se dá pela não-concordância com os rumos políticos tomados pelas forças libertadoras do Ulster. Assim, o nível horizontal de escrita é afetado pela presença vertical do social, fazendo com que o poeta, por meio de sua decisão, transforme o panorama literário de seu tempo. Para tanto, ele retoma os contos celtas, normandos e até mesmo britânicos, com o intuito de repensar a violência gerada pela guerra civil, assumindo o ponto de vista da

\footnotetext{
37 Apoio minha compreensão sobre a crítica francesa no estudo da intelectual brasileira especializada em literatura comparada. (NITRINI, 2000, p. 162)
} 
vítima, ou seja, do povo. Conseqüentemente, o "senso de lugar" apresentado por sua poesia faz com que reflitamos sobre a seguinte afirmação "nenhum poeta, nenhum artista tem seu significado completo por si próprio. Sua significância, sua apreciação vem da sua relação com artistas e poetas mortos" (ELIOT, 1932, p. 4) ${ }^{38}$. No trabalho de Heaney, essa afirmação de T.S. Eliot é de cabal importância, pois ele sempre incorpora - de uma forma ou de outra - outros escritores.

Nesse sentido, o significado de um retorno ao lugar de origem, ou "homecoming" à Irlanda, mesmo que esse seja à República e não a Ulster seria algo que nutre as esperanças e as novas experiências do poeta, e que, ao mesmo tempo, frustra por não haver uma concordância entre passado e presente, já que tanto o lugar de origem, quanto sua personalidade e valores mudaram: assim, o retorno acentua a necessidade de um novo exílio, pois o artista permanece constantemente em relação de "choque" (Cockerlebnis) e "experiência" (Erfharung) ) $^{39}$ com as formas de arte e culturas aprendidas no exterior. Esses choques, percebidos pela consciência poética através das imagens sobrepostas e fragmentadas de sua lembrança, transfiguram espaço e tempo em algo onírico, uma vez que elas se confundem e se misturam com as tradições irlandesas percebidas por sua individualidade (erlebnis). Entretanto, à medida que ele cria geografias de pensamento onde as barreiras nacionais são dissolvidas, o poeta recupera, por meio da rememoração, a experiência coletiva e acumulativa, algo que pode ser descoberto como em uma viagem (fahen). O retorno, por sua vez, acaba por ser vivido menos na materialidade do espaço, e mais na coletivização de sua experiência de viagem, algo como visto pelo próprio narrador benjaminiano.

Compreendemos que Heaney parte de um exílio comprometido com a matéria política e regional e, rompendo a cadeia de signos que o vincula somente ao presente,

\footnotetext{
${ }^{38}$ Muito antes das teorias de Mikhail Bakhtin e Julia Kristeva, T. S. Elliot, já no início século XX, inicia os estudos comparativos com uma perspectiva ainda hoje apreciada por teóricos e artistas. Para ele, a definição de um grande artista está sempre no remanejo das formas estabelecidas pela tradição. Essa visão, nos dias de hoje, é imprescindível nos estudos literários. Original: "No poet, no artist of any art, has his complete meaning alone. His significance, his appreciation is the appreciation of his relation to the dead poets and artists". (ELIOT, 1932, p. 4)

39 Walter Benjamin reescreve o conceito psicanalítico do choque na égide da cultura, afirmando que a experiência moderna é marcada pela rapidez de imagens e de estímulos que impedem o sujeito de fazer conexões com o passado. A experiência, em contrapartida, é o conhecimento adquirido por meio da vivência coletiva, como o próprio narrador que ele afirma ter desaparecido. A única forma capaz de fundir essas duas categorias contrárias entre si é a rememoração, assim, o que é individual, em sua transmissão duradoura, reverte-se em coletivo. (BENJAMIN, 1989, pp. 29 - 56)
} 
retorna a uma Irlanda diferente. Desta maneira, a cadeia de signos do passado é quebrada pelo "choque" com as imagens do novo espaço cultural, mas esse mesmo passado é "revisitado" com a relevância do olhar da "experiência". Conseqüentemente, ele percebe, conscientemente, que o lar construído em seus poemas não passa de uma abstração, ou seja, uma construção mental que é fruto de diversas subjetividades que se abrigaram dentro de sua persona literária. Assim, o poeta acolhe o cosmopolitismo ao aceitar os deslocamentos entre a República da Irlanda e diversos lugares do mundo. A nossa visão crítica e analítica pretende combinar, portanto, esses fatores de exílio, o cosmopolitismo e as polifonias literárias, de modo a ter uma visão mais abrangente da poética de Seamus Heaney, que tem uma boa recepção tanto pelos ingleses, quanto pelos irlandeses, e por que não, por muitos outros cidadãos de diversas nacionalidades, dadas as diversas traduções de seus poemas mais conhecidos.

O cosmopolitismo provindo dessa nova fase artística origina uma arte, a qual, preocupada com as questões de solidariedade em âmbito mundial, consegue criar uma nova significação para o lar, onde é possível imaginar outras configurações para o tempo presente. Por meio do recorte e costura de imagens tanto da história de seu país, quanto de outros, o poeta cumpre uma condição de solidariedade em sua poesia. Ao contrário de absorver aleatoriamente outras culturas, esse influxo seria um "'significante de consciência' em que a significação é representação, figuração, apropriação (delimitação estreita dentro de um contorno adequado à subjetividade), e marca"40. Não ligada somente ao respeito entre as diferentes formas culturais e as maneiras que estas são representadas literariamente, esta seria a absorção do todo social como vislumbrado por Gayatri Chakravorty Spivak:

o todo social, ao menos no que diz respeito ao seu objeto de estudo, é o que Nietzsche chamaria de fortgesetzte Zeichenkette - "uma contínua corrente de signos". A possibilidade de ação está na dinâmica da ruptura desse objeto, a quebra e o religamento da corrente. Essa linha de argumento não coloca a consciência contra o social, mas o vê constituído numa cadeia semiótica. Isso é, portanto, um instrumento de estudo que participa da natureza do

\footnotetext{
${ }^{40}$ Spivak defende que a consciência do subalterno não é separada da esfera social, mas é historicamente politizada. Original: "'solidarity' is seen as a 'signifier of consciousness', where signification is representation, figuration propriation (stringent de-limitation within a unique and self-adequate outline) and imprinting". (SPIVAK, 1988, p. 202)
} 
objeto de estudo. Ver a consciência, é, portanto, colocar o historiador em uma posição de compromisso irredutível. (SPIVAK 1988, p. 198) ${ }^{41}$

Sem tantas referências explícitas à política irlandesa, Heaney ganha espaço para compreender sua própria sociedade contemporânea que necessita minar fundamentalismos, criar novos intercâmbios sociais e aceitar diferentes formas de enxergar o mundo. De uma maneira mais filosófica, o autor busca o "cosmopolitanismo crítico" que possa, por meio do reconhecimento da "diversidade epistêmica" das sociedades contemporâneas, sugerir “diversas localidades espaciais e históricas da diferença colonial... [as quais] confronta[m] projetos administrativos globais e ideologias executivas da rede social”42. Só dessa maneira seria possível uma sociedade em que pudesse articular valores diversos, fazendo com que o dialogismo prevaleça. Essa também:

Implica [a] negociação da colonialidade de poder e da diferença colonial em um mundo controlado pelo capitalismo global. Os direitos do homem, ou direitos humanos, de fato, teriam que ser negociado através das linhas de gênero... mas também através da colonialidade de poder que estruturou e estrutura o mundo moderno/colonial em torno da diferença colonial baseada em raça. (MIGNOLO, 2002, p. 180) ${ }^{43}$

Baseadas em uma visão de que as diferenças e negociações culturais garantem uma força de mobilização social, pretendemos, nessa dissertação, observar como se dá mais precisamente esse novo exílio por parte da subjetividade artística, visto que esse se direciona para a aceitação da condição cosmopolita crítica. Na transição, que se dá a partir do livro Station Island (1984), o poeta começa a sugerir uma certa conformação com sua situação, uma vez que esta possibilita seu contato com novas pessoas e culturas. Além do

\footnotetext{
${ }^{41}$ Original: the entire socius, at least in so far as it is the object of their study, is what Nietzsche would call a fortgesetzte Zeichenkette - a 'continuous sign-chain'. The possibility of action lies in the dynamics of the disruption of this object the breaking and re-linking of the chain. This line of argument does not set consciousness over against the socius, but see it as itself also constituted as and on a semiotic chain. It is thus an instrument of study which participates in the nature of the object of study. (SPIVAK, 1988, p. 202)

${ }^{42}$ Por meio do exame de três estágios dos projetos cosmopolitas da modernidade - Grécia, Renascença Européia e Iluminismo - Walter Mignolo sugere uma quarta fase - a da contemporaneidade - através da qual é possível surgir um real reconhecimento da "colonialidade de poder" nas sociedades que tiveram a experiência do colonialismo. Original: "critical cosmopolitanism"/ "epistemic diversity"/ "emerging from the various spatial and historical locations of the colonial difference... confront[ing] managerial global designs of ideogues and executives of the network society". (MIGNOLO, 2002, p.179)

${ }^{43}$ Original: Imply negotiating the coloniality of power and the colonial difference in a world controlled by global capitalism. Rights of man or human rights, of course, would have to be negotiated across gender lines... but also across the coloniality of power that structured and still structures the modern/ colonial world around the racially grounded colonial difference. (MIGNOLO, 2002, p. 180)
} 
mais, também podemos observar retornos e afastamentos imaginários nessa nova fase, uma vez que há uma orquestração intertextual em que predominam diferentes tons: inglês, irlandês, russo, greco-latino, americano, dentre outros. Nesse sentido, pretendemos focar a análise de nossa dissertação no poema título do livro, cujo tema é a peregrinação do sujeito poético a Lough Derg, a peregrinação religiosa em homenagem a São Patrício. O poeta, metaforicamente travestido do "Angelus Novus" (BENJAMIN, 1996, p. 226) de Benjamin, observa sua trajetória de vida em que, a partir da ótica do exílio e afastamento, busca expurgar uma carga provinda tanto da tradição literária da qual faz parte, quanto dos acontecimentos históricos e cobrança das pessoas que marcaram sua formação. Porém, ao invés de um olhar nostálgico e saudosista, o poeta imprime os traços trágicos do anjo que, ao invés de ver uma seqüência de acontecimentos lineares e cadenciados, observa uma única e grande catástrofe. Querendo livrar-se dessa carga, ele não consegue, pois seus olhos estão voltados para o passado, enquanto a marcha do presente insiste em impulsioná-lo para o futuro, mesmo quando seu desejo é de retornar e juntar os fragmentos dispersos.

Deste modo, a pergunta norteadora de nosso estudo será: o que o poeta expurga com a sua peregrinação imaginária a Station Island? O que ele ganha e perde nesse percurso de conscientização? Como essa expurgação é feita? Quais os elementos formais que representam essa expurgação? E quais os efeitos que essa promove para uma poesia que está por vir? A partir disso, podemos compreender como o significado de lar passa de um aspecto mítico com a evocação de estórias Anglo-Saxônicas e Nórdicas, chegando a um cotidiano em que tanto o exemplo da pessoa comum, quanto o do grande escritor serve como inspiração. Portanto, "Station Island" também redefine a questão de como o poeta enxerga-se a si mesmo em relação ao outro e à sociedade. Em razão disso, sentimos a necessidade de compreender como o lado público e privado se articulam em sua poesia. A nosso ver, a confluência entre subjetividade artística e tradição cria ciclos de conscientização através dos quais o poeta consegue criar uma arte livre para versar sobre os mais diversos temas.

A fundamentação teórica que norteará nossa análise é o conceito de intertextualidade compreendido por Kristeva. Para ela:

Intertextualidade é... uma maneira de introduzir a história ao estruturalismo e seus textos órfãos... Contribui substituindo a idéia bakhtiniana de várias 
vozes em uma locução pela noção de vários textos dentro de um texto... Se fosse para encontrar um ponto comum entre esses conceitos, eu diria "fronteira", ou melhor, "soleira". Agora, com a estória psicanalítica, a "soleira", aquela zona in-between da qual falou Hannah Arendt, pode conferir não somente uma conexão temporal ou um ponto espacial, mas também ponto de fusão, uma abertura política e, mais do que todos, uma plasticidade mental. Essa perspectiva pode elucidar o próprio conceito de intertextualidade. Concebido como uma soleira cruzada por línguas e culturas, a intertextualidade expõe a subjetividade ao trabalho essencial, totalmente assumido como o único meio de sobrevivência em uma cidade de trabalhadores complacentes, ou a um virtuosismo jocoso, sem maiores consequiências para a cidade. Pode ser um momento melancólico de crise, ou a perda de uma voz e significado, um vazio e uma origem deslocada, e uma conquista rebelde de novas expressões poliformes contra qualquer identidade improdutiva ou linearidade totalitária. (KRISTEVA, 2002, p. 93$)^{44}$

Baseados nessa explicação, observamos que o conceito sofre algumas alterações, pois além da interseção vertical e horizontal na cadeia de textos acoplados por determinado autor, temos em seu escopo de abrangência "temas" - no sentido histórico e individual que Bakhtin confere à palavra (BAKTHIN, 1979, pp. 114-5 $)^{45}$ - de ordem psicanalítica, política e histórica. Desta maneira, o poema será o nosso horizonte interpretativo - ou para continuar com a terminologia bakhtiniana, nossa "significação" - contudo, as questões abordadas por ele dividem-se em torno da constituição de uma subjetividade observando o seu passado. Problematizando o passado, vemos que tensões históricas e políticas começam a se entrecruzar, e essas, devolvem a significação à subjetividade, constituindo-a e exigindo

\footnotetext{
${ }^{44}$ Kristeva expõe, nesse texto, a sua compreensão atual sobre a crítica da intertextualidade elaborada por ela. Em sua concepção, os "dois" que sempre dialogam na criação artística são a subjetividade e o texto. Original: "For me, intertextuality is a way if introducing history to structuralism and its orphan, lonely texts and readings...I contributed by replacing Bakhtin's idea of several voices inside an utterance with the notion of several texts within a text... If I were to find a common point shared by... these concepts I would say "frontier," or even better "threshold"... Now, within the psychoanalytical story, the threshold, that in-between zone Hannah Arendt spoke of, is able to render not only a temporal connection or a spatial point of contact, but also a social melting spot, a political openness and most of all a mental plasticity... This perspective can shed a new light upon the concept of intertextuality itself. Conceived as a crossed threshold between languages and cultures, intertextuality exposes the self either to an essential work, entirely assumed as the only means of survival in a city of complacent workers, or to a jocular virtuosity without direct consequences for the city. It can be at once a melancholic moment of crisis, a loss of voice and meaning, a void and displaced origin, and a rebellious conquest of a new polymorphous expression against any unproductive identity or totalitarian linearity". (KRISTEVA, 2002, p. 93)

${ }^{45}$ A noção de tema em Bakhtin está em relação de oposição ou não-oposição à significação. Enquanto "o tema da enunciação é na verdade, assim como a própria enunciação, individual e não reiterável. Ele se apresenta como a expressão de uma situação histórica concreta que deu origem à enunciação". A significação se refere a "elementos da enunciação que são reiteráveis e idênticos cada vez que são repetidos". (BAKTHIN, 1979, pp. 114-5)
} 
respostas. Entretanto, no processo de composição poética, todos esses diálogos e associações devem pautar-se na forma - maneira pela qual a "significação" se converte em “tema”. Sendo assim, o baixo contínuo, ou, ousando outra metáfora, a sinfônica dissonante dessa cadeia de significados, vem à tona por meio de uma forma estruturada e pensada, fazendo com que o poeta possa elaborar uma nova configuração poética.

Voltando para a questão forma, Vizioli ressalta:

na última fase, embora ligado ainda à terra e ao universo pessoal (basta recordar, em Station Island, os poemas 'A Hazel Stick for Catherine Anne' e 'A Kite for Michael and Christopher', que ele dedica aos filhos) Heaney, influenciado agora por um número maior de poetas não irlandeses, tanto modernos (como Joseph Brodsky e talvez William Carlos Williams - já que alguns vêem semelhança entre a métrica deste e as quadrinhas de versos curtos e sem rima que passou a empregar com certa freqüência), quanto antigos medievais (como Homero e Dante), vai se tornando mais alegórico e abrangente" (VIZIOLI)

A alegoria, como uma figura aberta para o poeta retomar a sociedade, juntamente com outras estruturas formais, faz com que sua poesia atinja um número muito maior de leitores, e garanta que a força literária de seu trabalho esteja em "permitir a sobrevivência da beleza num mundo em que regimes tirânicos a querem destruir" (BONVICINO, 1998), porém sem perder de vista que esse belo está pautado em um comprometimento crítico. Além de garantir um espaço à arte, ele orquestra uma série de valores e correlações cujos frutos maiores são demonstrar como a literatura contemporânea - especialmente a poesia pode criar um local de reflexão e conhecimento de diversos espaços culturais.

Sendo assim, no primeiro capítulo faremos uma análise sobre como Heaney relê sua própria trajetória poética a partir da óptica do eu: como esse se conforma no confronto com o outro. Para tanto, articularemos as vozes subjetivas de seu íntimo: aquela que se volta ao social e aquela que não se configura em um espaço e tempo bem definidos. Entretanto, de modo a problematizar esse cenário, iremos colocar a questão de como esse encontro com a tradição faz do poeta um "subalterno" ou "nativo informante", nos termos usados por Spivak. Já num segundo capítulo compreenderemos como ele percebe a tradição literária, no diálogo com fatos pessoais e políticos. Com isso, necessitamos entender como sua linha temática oscila na medida em que essa gama de vozes afeta a estrutura formal do poema. $\mathrm{O}$ último capítulo será um ensaio sobre como se confirma uma estética cosmopolita que se 
assemelha muito a um cotidiano prosaico, que tem respaldo no livre intercâmbio de estórias e culturas. Juntamente com a esquematização dos resultados obtidos com as análises, nossa conclusão mencionará, como exemplo, alguns conceitos que se solidificam com a publicação de seu livro mais recente, District and Circle (2006).

Ademais, nossa metodologia de análise poética se baseia no modelo exposto por Antonio Candido em seu Estudo Analítico do Poema (CANDIDO, 1996). De modo a revelar as tensões criadas pela dependência cultural entre a Irlanda do Norte e Inglaterra as quais constituem a subjetividade artística - compreenderemos como a apropriação das formas anglo-saxônicas cria uma forma de resistência cultural contra a tentativa de homogeneização cultural da Irlanda do Norte. Assim, leva adiante sua posição posta em An Open Letter, em que ele defende sua raiz irlandesa. O método da Formação da Literatura Brasileira (CANDIDO, 1959) também nos auxiliará na maneira de compreender a obra de Heaney. Enquanto Candido analisa como as obras européias penetram na literatura brasileira e a redefinem a partir da óptica da localidade, nós tentaremos compreender como Heaney, a partir da apropriação da literatura inglesa e européia, produz uma obra que redefine padrões, tanto dentro como fora do lugar em que faz parte. Em sua fase mais transnacional, estudaremos como o poeta reverte a condição de dominação da cultura irlandesa, criando uma identidade própria, não mais una e contínua, mas transcultural.

Ao fazermos isso, estaremos solidificando a presença do exílio como um prérequisito para a compreensão da poética de Heaney. Nesse sentido, a correlação entre a subjetividade e a tradição, que posteriormente origina uma arte cosmopolita, conforma uma linha original e contemporânea para se examinar profundamente essa obra tão inquietante, a qual solicita de seus leitores uma constante atenção e uma mente aberta para os eventos diários. A poesia daquele que fora requisitado pelo pai "To find me a bubble for the spirit level/ And a new knot for this tie" (HEANEY, 1998, p. 433), fazendo com que ele cresça dividido entre o imaginário e o real (nível espiritual e gravata), o qual o encerra em um espaço entre fronteiras ou, até mesmo, soleiras. 


\section{A Polifonia Poética de "Eus"}

"Except that we know the old stories... We sleepwalk through a No Man's Land

Lipreading to an Orange band.

Continually, therefore, we rehearse

Goodbyes to all our characters

And since both would have it both ways,

On the oily roll of calmer seas

Launch coffin-ship and life boat, Body with soul thus kept afloat, mind open like half door

To the speckled hill, the polvers' shore"

(LONGLEY, 1986, p. 221)

"Take hold of the shaft of the pen.

Subscribe to the first step taken

from a justified line

into the margin"

(HEANEY, 1998, p.269)

\section{DA Periferia Ao Centro ou Do CEntro À PERIFERIA?}

Atualmente, no campo dos estudos irlandeses pós-coloniais, há um extensivo debate no que concerne à posição sócio-histórica da Irlanda. Se observada do ponto de vista cultural, há uma tendência a associá-la com as demais colônias mundiais, pois, de acordo com Joe Cleary:

as mais evidentes correspondências entre a Irlanda e as colônias britânicas do além-mar, não estão relacionadas a comparações imediatas... mas com afinidades abrangentes, como por exemplo, gêneros literários, estruturas de sentimento e problemas intelectuais que emergem do entusiasmo revolucionário que sucumbe à tristesse e desespero pós-revolução. (CLEARY, 2004, p. 271) ${ }^{46}$

\footnotetext{
${ }^{46}$ Joe Cleary faz um necessário mapeamento cultural cujo resultado revela até que ponto a sociedade irlandesa continua a ser dominada pela Grã Bretanha. Desta maneira, o autor analisa as posições favoráveis e contrárias aos estudos pós-coloniais na ilha. Se por um lado estes são considerados por alguns como "um avanço em novas maneiras de se pensar a evolução da cultura e sociedade irlandesa", por outro lado, há controvérsias que os vêem como "um desenvolvimento retrógrado escoriado por conservadores como uma cruel e injustificada
} 
Entretanto, se compreendida do ponto de vista econômico, há uma ênfase maior em seu sucesso comercial, pois suas práticas industriais tendem a conviver em constante conflito com uma linha de pensamento na qual grandes complexidades são desviadas da percepção histórica de dominação e colonialismo (LLOYD, 2000) ${ }^{47}$. Em decorrência desse paradoxo, a Irlanda dos dias de hoje se posiciona entre o passado colonial e o presente capitalista globalizado que insiste em apagar as questões referentes a esse legado.

Enquanto ambas as posições possuem subsídios históricos e sociais para serem sustentadas, acreditamos que a articulação dessas duas formas de raciocínio seja produtiva para a compreensão do legado cultural produzido por Seamus Heaney, principalmente porque seu trabalho perpetua formas ambíguas e contraditórias de enxergar seu lugar de origem. Como filho mais velho de pais católicos e agricultores o poeta, desde muito cedo, aprendeu a conviver com diferentes formas de cultura atuando em sua percepção de mundo:

Estava simbolicamente localizado entre as marcas da influência inglesa e a sedução da experiência nativa, entre o a 'propriedade privada' e o 'pântano'. A 'propriedade privada' era cercada, coberta de arbustos, além de nossos horizontes; o pântano era juncoso e traiçoeiro, um lugar perigoso para crianças. (HEANEY APUD GRAY, 1995) ${ }^{48}$

A partir do excerto acima, podemos entrever um certo receio em relação às duas formas pelas quais o autor reconhece o mundo do qual faz parte: enquanto não liga os adjetivos mecânicos relacionados à 'influência inglesa' e à 'propriedade privada', ele associa, através da conjunção 'e' os predicados 'juncoso' e 'traiçoeiro', referentes à 'experiência nativa'. Com base nessa adjetivação percebemos que, se por um lado as fontes culturais inglesas permanecem recônditas devido ao seu caráter opressor, por outro lado, as

politização do debate estético".Original: "The most telling correspondences between Ireland and the over-seas British ex-colonies have much less to do with direct contacts or influence... than they do with certain broad affinities of literary genre, structures of feeling, and intellectual problems that emerge when anti-imperial revolutionary excitement succumbs to post revolutionary tristesse and despair". (CLEARY, 2004, p. 271)

${ }^{47}$ David Lloyd discorre sobre a configuração política e social atual da Irlanda. Trata-se de uma temática que causa enormes controvérsias dentro do contexto de estudos irlandeses: a questão da Irlanda não ser um espaço diaspórico e pós-colonial, assim como são outros países que sofreram a experiência da colonização. Baseado em uma linha teórica sociológica de Estudos Subalternos, influenciada pelo Marxismo frankfurtiano, o autor tece argumentos que defendem a opinião de que a Irlanda possui ambos os traços de países desenvolvidos e Pós-Coloniais. (LLOYD, 2000, p. 379)

${ }^{48}$ Trecho retirado de uma entrevista de Heaney para a revista americana Time quando ganha o Prêmio Nobel. Original: "I was symbolically placed between the marks of English influence and lure of the native experience, between the 'demesne' and 'the bog'. The demesne was walled, wooded, beyond our ken; the bog was rushy and treacherous, no place for children'. (HEANEY APUD GRAY, 1995) 
irlandesas oferecem desassossego e atenção. Como resultado de tais percepções, observamos que os elementos naturais do 'pântano' são exatamente:

os corpos da idade do ferro desenterrados das trufeiras (sobre os quais ele leu primeiramente no livro As Pessoas do Pântano de P.V. Glob) [e que] inspirou alguns de seus melhores poemas... ajudaram Heaney a se distanciar e a focar nas vítimas do conflito da Irlanda moderna. (CAREY, 1998, G9) ${ }^{49}$

Por meio da experiência histórica da Irlanda, metamorfoseada nos corpos encontrados nos pântanos, compreendemos que as 'pessoas do pântano' são um receptáculo mumificado onde a história nativa, ou a tradição, é preservada das cercas e dos arbustos, frutos do colonialismo e modernização.

Como conseqüência do choque entre tradição e modernidade, Heaney apresenta uma poética ambígua em que reminiscências do passado colonial convivem não pacificamente com instituições que as reprimem. Esse mecanismo, que é denominado de “processos de deslocamento" na terminologia de Lloyd, pode ser descrito como a contínua e desigual transmissão de memórias acerca da resistência e aceitação dos preceitos históricos coloniais. A nosso ver, essa é a maneira através da qual a sociedade é refletida em sua obra. Como explica o crítico:

Hibridismo é um processo apenas parcialmente apreendido quando visto como uma mistura e justaposição cultural em que o tradicional é absorvido e punido pelo moderno, ou o nativo pelo Ocidente. Manifesto em formas que vão desde artefatos como baladas populares e esculturas turísticas, até instituições do Estado, o que se chama de hibridismo envolve um processo contínuo e contraditório de deslocamento recíproco e produtivo de um pelo outro, através de formas culturais que são constituídas como mutuamente incomensuráveis, mas irredutivelmente contemporâneas umas as outras. $($ LLOYD, 1999, p. 46)

\footnotetext{
49 John Carey, explica que a popularidade de Heaney encontra-se na recuperação das raízes históricas da Irlanda e na clareza da linguagem. Para ele, o pântano é a grande metáfora de Heaney por presentificar a história. Original: "The iron-age corpses dug out of peat-bogs (which he first read about in P.V. Glob's The Bog People) have inspired some of his greatest poems... they helped Heaney both to distance and to focus the victims of modern Ireland's conflict". (CAREY, 1998, G9).

50 David Lloyd examina a questão norte-irlandesa à luz de "práticas pós-coloniais" e não "teorias póscoloniais. Para ele, o verdadeiro hibridismo existente na Irlanda é aquele que surge do confronto entre tradição e modernidade. Esse choque é originário da presença da memória negativa das histórias subalternas de resistência ao colonialismo. Original: "Hybridity is only partially grasped as a process of cultural mixing and juxtaposition in which the traditional is combined and inflected with the modern or the native in the Western. Manifested in forms that range from artifacts like street ballads or tourist sculptures to institutions of state, what has been termed hybridity involves a continual and contradictory process of productive and
} 
Pautados nessa forma de hibridismo desenvolvida pelo crítico, compreendemos que a posição periférica-central da Irlanda do Norte atual traria algo de nativo, como uma fonte de resistência, mas que, devido a forças hegemônicas, acaba por ser ofuscada. A própria busca arqueológica do poeta seria esse constante escavar da memória que se perde e se fragmenta dentre as disputas.

Desta forma, a presença da natureza e da propriedade privada faz com que Heaney compreenda o quanto sua terra foi, e ainda permanece afetada por disputas e violência, mesmo que essas sejam veladas pelas ideologias progressistas, como explicitamos na introdução. Continuando com os apontamentos feitos por Lloyd, a Irlanda do Norte, durante a década de 1960, fora palco de experimentação de técnicas de vigilância coercivas que envolviam avançadas tecnologias, servindo de "laboratório social" para a sua implementação na Europa. Essas, nas palavras do crítico:

Envolve(m) uma lógica diferente da intervenção do Estado que constitui um novo contínuo entre aparatos de Estado, que estavam direcionados a regulação não-violenta e hegemônica da sociedade privada e civil, e a força coerciva dos aparatos repressivos. Essa envolve... a profunda penetração na sociedade civil por meio de técnicas de vigilância através das quais a população é reconstituída como sujeitos da autoridade estatal e não como cidadãos que devam ser interpelados. (LLOYD, 1999, p. 47) ${ }^{51}$.

Não podemos também nos esquecer de que tais muros privados podem evocar as divisórias colocadas nas cidades para separar católicos e protestantes e a constante divisão social em guetos. Sendo assim, a configuração que Edward Said entrevê para o projeto Imperial do século XIX continuava presente na Irlanda do Norte, pois, "o imperialismo... era um processo multissecular e contínuo de conquista, rapacidade e exploração científica" (SAID, 1999, p. 279) ${ }^{52}$. Portanto, a única forma de compreender essas camadas de significados geradas pela dominação colonial - e re-interpretada através dos séculos por gerações de intelectuais - seria penetrando na escuridão do pântano, a qual, por trazer

reciprocal displacement of one another by cultural forms that are constituted as mutually incommensurable but are irreducibly contemporaneous with one another". (LLOYD, 1999, p.46)

${ }^{51}$ Original: "It involves also a different logic of state intervention that constitutes a new continuum between state apparatuses that were directed at the non-violent or hegemonic regulation of private and civil society and the coercive force of repressive apparatuses. It involves... the deep penetration of civil society by surveillance techniques through which the population is reconstituted as subjects of state authority rather than citizens to be interpellated." (LLOYD, 1999, p 47)

${ }^{52}$ Said explora a poesia de Yeats como uma fonte de resistência, no momento em que a leitura do poeta como fascista já havia sido solidificada. (SAID, 1999, p. 279) 
lembranças dispersas, deve ser repensada desde sua origem, ou na metáfora usada pelo poeta, desde sua infância. Portanto, no começo de sua carreira o poeta revisita esse período de sua vida e demonstra como a tradição, combinada com a modernização - constituição de uma natureza duplamente hostil - afeta sua subjetividade artística.

Durante a "Revival" ou a "Counter-Revival", a natureza foi largamente utilizada como fonte de resistência, pois para a imaginação anti-imperialista o "espaço doméstico na periferia foi usurpado e utilizado por estrangeiros para seus próprios fins. Portanto, faz-se necessário... inventar ou descobrir uma terceira natureza... derivada das carências do presente" (SAID, 1999, p. 285). De modo a absorver e recriar o verso pastoral Heaney "textualiza" (EAGLETON, 1980, p. 67) ${ }^{53}$ a natureza, permitindo que o leitor a interprete de acordo com relações literárias e históricas. Sendo assim, o autor incorpora duas visões acerca do mundo natural: a harmonia bucólica e solitária de William Wordsworth e as inquietudes históricas e corriqueiras de Patrick Kavanagh, criando uma poesia que é forjada no próprio cerne dos confrontos culturais. Heaney segue seu exemplo principalmente quando este afirma:

o grande poeta é aquele que queima, na forja de sua alma, o material bruto [ou ferida] da vida e produz daí a essência lasciva-criativa... tudo que o poeta faz é explodir os átomos de nossa experiência comum. (KAVANAGH APUD HARMON, 1982, p. 229) ${ }^{54}$

A “experiência comum”, expressa no início de sua poesia através de perturbações bucólicas, é reflexo de uma sensibilidade poética moldada pelas angústias psicológicas de um artista periférico, cuja história de dominação é inserida nos versos. Podemos observar tal inquietação nos poemas dos pântanos e na obsessão inicial com imagens de ratos - "An Advancement of Learning," "Blackberry Picking" e "Personal Helicon" (Death of a Naturalist, 1966) - perturbando a harmonia pacífica de uma poesia idílica.

Seu primeiro poema, "Digging" (Death of a Naturalist, 1966) sugere um compromisso individual e coletivo, causando dúvida e catarse. Mesmo focando a temática

\footnotetext{
53 Terry Eagleton acredita que Seamus Heaney textualiza a natureza, permitindo que essa seja lida, e ao mesmo tempo, reconhecendo a materialidade histórica da linguagem poética. (EAGLETON, 1980, p. 67).

${ }^{54}$ Parte do livro em que o autor expõe a importância do legado de Patrick Kavanagh. Original: The great poet are those who burn in the smithy of their souls the raw material of life and produce from it this erotic-creative essence... all the poet does it to explode the atoms of our ordinary experience. (KAVANAGH APUD HARMON, 1982, p. 229).
} 
do poema na rememoração das tradições agricultoras de sua família, essas ecoam a dominação de sua terra, cujo episódio mais marcante foi a Grande Fome no século XIX, que forçou mais de um milhão de irlandeses a emigrarem para Europa e Américas. A partir disso, mesmo se aproximando do "material bruto" da realidade, o poeta dele se afasta, pois a escrita poética não faz parte do universo de seus antepassados familiares, que nas suas palavras, são "nem iletrados, nem literários" (HEANEY APUD CAREY, 1988, p. 40). Podemos compreender que Heaney começa a percorrer a trajetória de um exílio psicológico que se afasta da agricultura familiar e começa a trilhar um caminho que o impulsiona para fora desse contexto. A própria analogia com a Grande Fome sugere um afastamento doloroso e traumático. Desta maneira, esse primeiro recorte pode ser entendido como um nascimento marcado pela ambigüidade e fragmentação por ser concebido em meio à situação colonial em que a Irlanda do Norte ainda vivia.

Posteriormente ao nascimento artístico, Heaney descreve, em Death of a Naturalist (1966), o seu despertar para uma subjetividade cindida, ou separada do lugar de origem. Ao trabalhar com a natureza hostil e com o sentimento de não pertencimento, o poeta se desvincula das idealizações românticas. Sendo assim, em "Early Purges", "Gravities" e "Storm on the Island" ele demonstra, através das imagens de gatos assassinados ou rebelados, que não se encontra em um lar, mas em uma fragmentação de lares, cuja construção está subordinada ao medo: "we are bombarded by the empty air./ Strange, it is a huge nothing that we fear" (HEANEY, 1966, p. 38). Portanto, como conclusão do volume, o autor, inspirado pelos animais descritos nos poemas, reafirma a sensação do nãopertencimento a esse mundo natural. Ao mesmo tempo em que ele se afasta, psicologicamente desse universo, ele também aceita o projeto de um exílio interno, ou seja, refletir sobre sua origem com base em ideais mais abrangentes que possuam a perspectiva histórica colonial.

Tal mapeamento prévio das imagens e motivações iniciais de Heaney nos faz compreender que há um centro de motivações do qual sua poesia se origina. Se para o poeta “a poesia pode criar uma ordem tão verdadeira quanto o impacto da realidade externa, e tão sensível quanto às leis internas do ser poético, como as reverberações da água do balde na 
copa da casa" (HEANEY, 1998, p. 449, 450) ${ }^{55}$, entendemos que esse centro é exatamente a sociedade periférica norte-irlandesa cujas violentas reverberações abalam a aparente harmonia da metrópole. Como as próprias transformações que se operam na água, a percepção dessa paisagem social adversa e inamistosa sofre rearranjos e, nos próximos volumes em que a faceta naturalista de sua personalidade torna-se menos expressiva, a questão arqueológica toma o foco principal. Assim, a psique do autor se dissolve entre os poemas que retomam os corpos dos pântanos e as circunstâncias pelas quais esses vieram a perecer - caracterizando o intercâmbio entre passado e presente.

A dialética entre passado - representado por "bog people" - e presente caracterizado pela luta armada que provoca sua opção pelo exílio - visto que o poeta deixa a Irlanda do Norte após o início do período chamado "The Troubles" latente e explícita até Station Island (1984). Seria importante ressaltar o fato de que o livro Field Work (1979) se torna uma despedida dos poemas mais abertamente políticos, como "A Postcard from North Antrim", e declara que sua arte deve se voltar para o interior, como explicitado por "The Harvest Bow". É significativa a re-escritura de vidas de personalidades, como a do rei Ugolino, em "Ugolino", em que a subjetividade lírica se apodera de uma determinada tradição e a transpõe para o tempo presente. Ademais, tal técnica literária possibilita sua transposição para um outro nível de exploração literária: sua fase de revisão poética e da intertextualidade que "Station Island" cria e retoma. Portanto, o centro inicial sofre um rearranjo e sua poesia começa a ficar cada vez mais complexa, caracterizando o que seria naturalmente um reflexo dessa sociedade contraditória por si mesma: um autor católico do Norte, posicionado na periferia européia que sofre com atentados terroristas e divisões sectárias, mas morando com sua família na República, em que as grandes corporações trazem um avanço político e impulsionam o universo das artes.

Segundo O’Toole, a República da Irlanda apresenta, simultaneamente, o seguinte cenário:

\footnotetext{
${ }^{55}$ Original: "poetry can make an order as true to the impact of external reality and as sensitive to the inner laws of the poet's being that ripples ... across the water in that scullery bucket". (HEANEY, 1998, p. 449, 450).

${ }^{56}$ Os “Troubles" se iniciaram em 1969 quando a minoria católica, inspirada no Movimento de Direitos Civis Norte Americano, começa a exigir seus direitos. Tais protestos são vistos como uma nova tentativa de união das Irlandas, levando a atitudes extremas por parte do governo inglês. A situação perdura até a década de noventa, quando o IRA (Exercíto Republicano Irlandês) anuncia o cessar fogo. (BROWN, 2004)
} 
esse complexo processo em que a liberação econômica, a rapidez das comunicações e a homogeneização cultural estão ligadas, afeta todos no planeta. Isso cria perdedores e ganhadores. E a grande vencedora é a Irlanda. A República da Irlanda é o país mais globalizado do mundo. Ela está na liderança de um processo que afeta todas as partes do planeta. (O'TOOLE, 2003 , p. 77$)^{57}$

Assim, as diversas identidades literárias assumidas por Seamus Heaney se assemelham a essa rapidez nas comunicações e nas trocas culturais, porém, ao mesmo tempo, trazem consigo todas as contradições e ambigüidades produzidas com a globalização. Com isso, a estética que urge por questões mais abrangentes, somada à incerteza em relação ao centro de imagens nas quais deseja se apoiar, refletiria, performaticamente, as relações sociais do mundo interconectado. Para tanto, o poeta e reinventa uma subjetividade que, por estar cindida entre tradição e modernidade, volta-se para as ruínas históricas do que não foi deixado de lado na representação histórica do processo colonial, tanto econômico quanto cultural: o subalterno, o nativo informante, o marginal, o rebelde, dentre outros. Portanto, ao contrário do que Eugene O’Brien afirma: "o desenvolvimento de Heaney está em paralelo - e antecipa - a psique irlandesa através desses cinqüienta anos" (O'BRIEN, 2002, p. 4), acreditamos que o poeta imprime em sua forma artística as contradições de uma nação aberta ao sucesso comercial, mas marcada com as antinomias históricas da pobreza e da exploração.

Nesse contexto, o melhor poema para representar esses dilemas é a longa peregrinação de "Station Island" (Station Island, 1984), principalmente porque ele encena uma escavação cultural e histórica, onde os personagens escolhidos são representantes de momentos bem definidos, fazendo com que ele seja obrigado a re-definir seus paradigmas literários. Desta maneira, nas próximas seções, iremos analisar a trajetória que o poeta traça e como cria uma poética que pode ser de um novo exílio ou então de uma busca a um novo espaço cultural na própria República da Irlanda. Além do mais, tentaremos compreender a

\footnotetext{
57 Texto retirado da palestra que Fintam O'Toole profere na conferência ISAIL de 2002, em que afronta a condição dúbia da Irlanda ser considerado um país de periferia, mas ter sua cultura e literatura estudada e apreciada por intelectuais das mais diversas regiões do mundo. Para ele, é preciso observar a cultura irlandesa como parte de um processo de globalização liderado pelas pessoas comuns. Original: "this complex process in which economic liberalisation, speed of communication and cultural homogenisation are intertwined, affects everyone on earth. It creates losers and winners. And the big winner is Ireland. The Republic of Ireland is the most globalised country on earth. It is at the leading edge of a process that touches very every part of the planet”. (O’TOOLE, 2003, p. 77)
} 
intertextualidade a partir da significação de cada artista evocado - seja ele irlandês ou pertencente a contextos culturais de outros países.

Ademais, além de propor uma nova busca, "Station Island" é um poema que, nos moldes dos fluxos de consciência joyceanos e na procura de Stephen Dedalus por uma arte liberta do sufocante clima cultural irlandês, retoma as principais questões debatidas ao longo de sua poesia: os anseios por uma arte social e historicamente crítica, sua identificação em negativo com a arte inglesa e a necessidade de buscar em outras comunidades relações com sua própria arte. Sendo assim, a escolha desse longo poema se dá devido ao fato de ele dramatizar a peregrinação de um exilado no qual a escrita tornouse um lar. Como afirma Adorno sobre sua experiência de exílio na Califórnia, nos Estados Unidos "para quem não tem mais pátria... o escrever se torn[a-se] sua morada", mas que, ao ser fiel à experiência artística, "nem sequer é permitido ao escritor habitar o ato de escrever" (ADORNO, 1993, p. 51) ${ }^{58}$, a subjetividade torna-se um microcosmo que, ao mimetizar a realidade, resiste a esse mundo de rápidas tecnologias e bruscas mudanças. Embora haja uma tonalidade negativista atuando no interior dessa escrita desraigada de qualquer pátria, acreditamos que é exatamente essa a morada mais adequada para as histórias que o poeta pretende retomar.

Se para Spivak as histórias subalternas são aquelas que constantemente se esforçam para transformar as condições de impossibilidade em possibilidade (SPIVAK, 1988), a inserção dos personagens que a moldam no poema faz com que a zona insípida e desconfortável habitada pela escrita seja a maneira pela qual o poeta consiga entrever outras possibilidades de agência artística e, por que não, política. Ao traçar paralelos entre fronteiras e entre culturas, a subjetividade traz:

para os debates irlandeses... engajamento com urgentes preocupações irlandesas dentro de um contexto internacional de lutas para uma mudança radical, abrangendo assuntos práticos... e analíticos... Mas, também... se

\footnotetext{
58 Apontamentos de Theodor Adorno a respeito de sua própria experiência de estar exilado nos Estados Unidos após a Segunda Guerra Mundial. Para o filósofo, a vida anterior do émigré é anulada (princípio de anulamento), fazendo com que o sujeito possa construir um lar dentro de sua escrita. Ademais, a paisagem cultural americana corroborava para o tom negativista do filósofo. (ADORNO, 1993, p. 51)
} 
pauta[ndo] nas práticas de descolonização e nas lutas contra a Nova Ordem Mundial que continua através do globo.. ${ }^{59}$ (LLOYD, 1999, p. 108)

Desta maneira, Heaney cria não só um deslocamento subjetivo e geográfico, mas também epistemológico dentro de sua escrita, pois a cada momento em que uma aparente harmonia artística é construída, o espírito ativo daquele que deve inventar-se a si mesmo e aos outros intervém, e o faz repensar nas categorias com as quais ele está trabalhando. Assim, através de uma constante inquietação e certeza de que as chegadas resultarão em uma nova partida, a relativa liberdade artística engendra "essencialismos estratégicos" (SPIVAK, 1990, p. 11) através dos quais os debates culturais não farão dele apenas alguém que traduza para o mundo o que é viver na situação de terrorismo da Irlanda do Norte na década de oitenta, mas explique como essa narrativa pode e deve ser inserida no contexto mundial.

\section{Heaney por Heaney - A Polifonia Poética da Subjetividade}

O poema "Station Island”, devido ao seu caráter cíclico e intertextual, esboça uma peregrinação medieval e dantesca porque remete à via crucis de Jesus, à busca de autoconhecimento e à liberdade artística, respectivamente. Porém, se para Adorno a subjetividade torna-se categoria estética somente na sua "objetificação" (ADORNO, 1970), acreditamos, conjuntamente com o crítico, que esse construto artístico mimetiza uma aparente liberdade artística pois, ao tornar-se objeto, volta os olhos a si mesmo e compreende como é formado através de metamorfoses antropofágicas em que, ora assume, ora rejeita, a personalidade subalterna e/ou estilo literário de indivíduos e autores importantes para a sua constituição. Deste modo, temos uma categoria estética mediada não somente pela história e pela literatura, mas também pelo tratamento objetivo e material das

\footnotetext{
${ }^{59}$ Original: to the Irish debates... engagement with grasping Irish concerns within an international context of struggles for radical change, ranging from practical... to analytical matters... Rethinking... political ends and strategies will draw on the rich repertoire of alternative social practices in Ireland as well as the dehierarchization of traditional assumptions and practices. But it will need to draw no less on the practices of decolonization and struggles against the New World Order that continue all over the map, among minority communities in the industrial world as in the postcolonial nation-states. (LLOYD, 1999, p. 108).
} 
categorias estéticas, cuja função é desenvolver uma forma artística menos individualizada, mas que responda aos apelos do social.

Se por um lado o poeta retrata sua peregrinação a Lough Derg, onde os fiéis são submetidos a uma série de rituais, como ciclos de oração ao ar livre, em torno de "leitos penitenciais" $(2008)^{60}$, e dentro da Basílica de São Patrício, durante as missas - de modo a expurgar seus pecados - por outro lado, Heaney cria um colapso entre o transcendental e o político, ou entre o subjetivo e objetivo na terminologia adorniana. Em relação ao poema, Heaney afirma: "a principal tensão é entre dois comandos contraditórios: ser fiel à experiência histórica e coletiva e ser verdadeiro ao reconhecimento do 'eu' emergente" (HEANEY APUD CORCORAN, 1986, p. 160) ${ }^{61}$. Enquanto trata de assuntos relativos à sua psique interior, o poeta estabelece uma relação íntima com sua identidade particular irlandesa e celta, porém, quando entra na égide do público e histórico, aproxima-se da herança cultural d'A Divina Comédia de Dante Alighieri, pois está estabelecendo um diálogo com uma obra literária cuja importância para o cânone literário mundial provém de suas inovações estéticas e representações históricas. A partir desse ponto, ele começa a expandir sua arte para além do local, o qual se inscreve no poema por meio dos personagens do passado, e cobra de Heaney (ou da subjetividade literária construída por Heaney) um aberto posicionamento político frente aos acontecimentos da sociedade na época.

Nessa ligação entre o individual e o coletivo, o poeta representa as problemáticas de uma subjetividade que se desenvolve em meio a uma sociedade cujas ambigüidades identitárias e políticas "deriva[m] de uma... crise colonial" ${ }^{62}$. Sendo assim, mesmo tentando penetrar em sua interioridade, o poeta compreende o quanto essa é fruto de uma

\footnotetext{
${ }^{60}$ Sobre a origem dos "leitos de oração": Os leitos de oração penitenciais em Station Island pertencem ao período celta monástico. Eles são reminiscências de celas ou oratórios monásticos onde os monges passavam o tempo sozinhos, em oração. Encontram-se em círculos de seixos e pedras brutas enterradas no solo, algumas inclinadas em um precipício, e no centro de cada, há um crucifixo. Os leitos penitenciais são dedicados a sete santos, cada qual com algum tipo de associação à área. Um frade franciscano, Michael O'Cleary relata que a peregrinação é feita desde 1600 - segundo o mais antigo relato sistematizado. In. http://www.loughderg.ie/index.cfm/area/information/page/beds. Consultado em 16 de Janeiro de 2008, às $14 \mathrm{~h} 15$.

${ }^{61}$ Original: "The main tension is between two often contradictory commands: to be faithful to the collective historical experience and to be true to the recognitions of the emerging self". (HEANEY APUD CORCORAN, 1986, p. 160)

${ }^{62}$ Livro organizado por Seamus Deane em que críticos marxistas, como Terry Eagleton, Fredric Jameson e Edward Said analisam um aspecto cultural da Irlanda com base em sua história colonial. (DEANE 1997, p. 06)
} 
complexa relação entre vozes, e até mesmo pessoas que o constituem. Desta maneira, retornamos à "objetificação"63 da subjetividade como descrita por Adorno, pois enquanto o poeta tenta penetrar em sua constituição artística interna, ele encontra as impossibilidades colocadas por sua sociedade. Sendo assim, na continuação de seu comentário, ele exemplifica sua posição:

espero ter podido dramatizar essas forças ao me encontrar com sombras de minha vida-sonho e que também foram habitantes do mundo real irlandês. Elas talvez deram voz às exigências da ortodoxia e à necessidade de reconhecer tais exigências. Elas puderam averiguar a validade do compromisso. (HEANEY APUD O'BRIEN, 2002, p. 160) ${ }^{64}$

Desta maneira, ao usar o termo "sonho" para classificar a sua vida, que é representada pela subjetividade artística, o autor cria um espaço onde a realidade é vista por meio do onírico, remetendo o leitor a um universo pautado no inconsciente e na indeterminação surrealista, com a qual ele já havia trabalhado em "Summer 1969" (North, 1975). Nesse poema as imagens, por oscilarem entre o real e o imaginário, o sonho e a realidade, o sofrimento e o gozo, sugerem uma liberdade artística perante uma história repressora. Além do mais, ele recupera a herança modernista do poeta espanhol Garcia Lorca de modo a afirmar a validade da arte como um importante instrumento de reflexão em momentos históricos decisivos - nesse caso, a guerra civil irlandesa (ANNUNCIAÇÃO, 2005) ${ }^{65}$ ecoando a guerra civil espanhola. Essa absorção da tradição vanguardista, que é mais abertamente desenvolvida na seção IV, faz-nos refletir sobre como seu corpo subjetivo é despedaçado de modo a ser reconstituído coletivamente.

Partindo do pressuposto de que Heaney desmembra a sua subjetividade para produzir uma multiplicidade de personas, compreendemos que um desses elementos seria a imagem do subalterno. Enquanto na primeira fase de sua poesia o poeta tinha como centro a presentificação histórica do colonialismo, em "Station Island" esse é delineado pelos cidadãos irlandeses, herdeiros do poema "Act of Union" (1972) e descendentes do poema

\footnotetext{
${ }^{63}$ Utilizamos o termo "objetificação" como categoria estética, distintamente de "reificação", que é uma categoria econômica.

${ }^{64}$ Original: "I hope that I could dramatize these strains by meeting shades from my own dream-life who had also been inhabitants of the actual Irish world. They could perhaps voice the claims of orthodoxy and the necessity to recognize those claims. They could probe the validity of one's commitment". (HEANEY APUD O'BRIEN, 2002, p. 160).

${ }^{65}$ Para a análise completa do poema "Summer 1969" ver Annunciação, Viviane Carvalho da, 2004/ 2005, USP.
} 
posterior "Strange Fruit" (1972) ${ }^{66}$. Sendo assim, esses cidadãos subalternos, que em sua poesia inicial foram reprimidos ("foreclosed") no sentido Lacaniano, afloram e se instauram em sua constituição subjetiva. Usaremos o conceito de foreclosure de Lacan por intermédio da leitura de Spivak (SPIVAK, 1999, pp. 4-5) que identifica o subalterno como o agente contido no Simbólico, e reinscrito implicitamente no Real ${ }^{67}$. Enquanto o lugar da linguagem poética, identificado como Simbólico por Lacan, reprimiu a voz desse Outro, ele, retorna no "cordão umbilical da linguagem" (LACAN, 1992, p. X), ou Real, através das combinações métricas. Um dos exemplos em que esse mecanismo de revelação do que foi oprimido é o retorno das combinações redondilhas maiores e menores na cadência jâmbica de muitos de seus versos - métrica típica da língua do opressor. Seria como se a cultura popular irlandesa se instaurasse implicitamente na métrica (algo próximo da repressão lacaniana) e retornasse na leitura mais atenta do poema.

Desta maneira, ambos os discursos coloniais (pentâmetro jâmbico) e nativos (redondilhas) são constitutivos da subjetividade no Imaginário, que, ao mesmo tempo, rejeita e absorve o subalterno excluído ou o indivíduo imperial. Nesse sentido, a própria representação dramática de sua constituição identitária por meio do sonho, cujo corpo fragmentado representa "a desintegração do individual” (LACAN, 1992, p. 4), é uma maneira de revelar as partículas sociais reprimidas ("foreclosed") em sua arte. Ao retomar o coletivo e suas complicações na própria tradição literária, como Bejnamin ressalta sobre as técnicas criativas do surrealismo, o autor exibe sua subjetivação como um processo abstruso e irregular.

De modo a desenvolver nossa linha de pensamento, dividimos "Station Island" em três capítulos que explicam como o poeta reescreve seu percurso de exílio. Heaney, conscientemente, rememora os momentos mais significativos de um rompimento psíquico

\footnotetext{
66 "Act of Union" e "Stange Fruit" são poemas publicados no livro "North" e que tratam da questão colonial a partir da figura feminina. Enquanto o primeiro representa a colonização da Irlanda pela Inglaterra como um estupro que gera filhos bastardos, o segundo descreve o corpo de uma moça retirado do pântano cuja decapitação reverbera violência social da época.

${ }^{67}$ De acordo com a psicanalista Rosa Jeni Matz, a partir de leitura de Lévi-Strauss, Jacques Lacan constrói a tríade: Simbólico, Imaginário e Real, de modo a codificar o inconsciente freudiano. Na categoria do Imaginário, o inconsciente freudiano é repensado como dimensões imagéticas. Essas, por sua vez, se transformam em uma cadeia de significantes no Simbólico, o lugar da linguagem por excelência. O Real se caracteriza pela ex-sistência ao Imaginário e ao Simbólico, discernido pela modalidade lógica do impossível, sendo aquilo que não cessa de não se escrever. In. Palestra proferida por Elvira Gotter em 17 de Outubro de 2005, USP (informação verbal).
} 
com a terra natal, do qual surge a necessidade do afastamento geográfico. Característica cuja essência é dialética, pois embora o poeta tente se dissociar dos elementos mais provincianos de sua sociedade ("foreclosed"), ele próprio não consegue desviar o seu olhar do povo e participar de práticas folclóricas que são, na maioria das vezes, característicos da cultura popular irlandesa. Sendo assim, todo poema é uma afirmação e negação da cultura irlandesa, uma vez que o caminho escolhido por ele, é um lugar de expurgação de pecados e penitência. Ademais, a divisão do poema em três partes é significativa: enquanto a primeira trabalha com a infância e formação de um "eu" fragmentado, a segunda se volta para o espaço público e histórico, e a terceira vai ao encontro da síntese enviesada dessas duas posições.

Nessa seção analisaremos a primeira parte do poema em que a subjetividade do presente volta para o seu "eu" passado e tenta compreender como as questões envolvidas na sua formação pessoal são delineadas a partir de interferências sociais. Desta maneira enfocaremos os quatro primeiros poemas da seqüência, os quais, em sua raiz, remetem a tradições irlandesas por trazerem à tona o encontro do poeta com Sweeney. Se, por um lado, podemos interpretá-lo como personagem folclórico de cabal importância na literatura do poeta, por outro lado ele foi um amigo de família. Outro personagem com o qual ele dialoga é Lough Derg Pilgrim, criado por William Carleton, que descreve sua peregrinação católica dentro da Irlanda. E por último, uma figura bastante emblemática, um padre enviado às missões evangelizadoras nas colônias britânicas. Mesmo havendo uma força centrípeta que impulsiona Heaney para o centro das narrativas e estórias irlandesas, há outra força centrífuga que o impulsiona para fora deste centro; porém, o embate entre as duas produz desassossegos e incertezas.

Dentro dessas forças, as formas literárias inglesas e a irlandesas não deixam de atuar, pois a métrica escolhida pelo poeta varia de diversas maneiras - jâmbicos, redondilhos, alexandrinos, dentre outros que serão melhor explorados no decorrer do presente trabalho. Além do embate de forças cujas linhas divisórias são oscilantes por ora se confundirem, ora se repelirem, o poeta busca, igualmente, um senso de identidade e pertencimento. Contudo, a resposta para essa questão - ou o surgimento de mais questões é somente encontrada no final, quando ele finalmente encontra seu maior mentor literário: James Joyce. Ao produzir essa mis-en-scène psicológica e cultural, o poeta projeta 
"formações subalternas performativas" cujas memórias e práticas se instauram nas estruturas contemporâneas de resistência:

além do mais, embora a representação histórica de sua continuidade como descontínua, como esporádica, é sintoma de rumos imprevistos que as formações subalternas tomam abaixo da história oficial. A recorrência ou iteração, sempre sob nova forma, introduz um desvio na linha do tempo do estado: a curva, que resulta da evocação do passado aparente em um novo lugar, desloca determinações históricas e abrem espaço para lógicas culturais alternativas. (LLOYD, 1999, p. 78)

Sendo assim, dentre as "estruturas de sentimento" 69 postas por esse extenso poema, as mais importantes seriam aquelas relacionadas às escolhas e aos efeitos das mesmas para a constituição de sua identidade literária irlandesa, em que traços subalternos residuais emergem à superfície de uma poesia aparentemente harmônica. Mesmo ciente de que suas escolhas são determinadas por sua comunidade, o poeta oscila entre o partir ou permanecer, ser irlandês ou não ser, seguir um caminho coletivo ou individual, dentre outros. Como Helen Vendler afirma:

dentro da cultura familiar de Heaney, havia três escolhas plausíveis para o filho mais velho: herdar e manter a fazenda; tornar-se um padre; ou se tornar um professor de ensino secundário. (VENDLER, 1998, p. 93) ${ }^{70}$

Entretanto, o poeta prefere se abster dessas alternativas e seguir um caminho próprio, o qual possui continuidades e descontinuidades com relação às posições que lhe são oferecidas no início da vida profissional. Porém essas acabam retornando no poema quando ele dá voz às escolhas que foram ignoradas anteriormente. Desta maneira, as quatro

\footnotetext{
${ }^{68}$ Original: Furthermore, tough, the historical representation of their continuity as discontinuous, as sporadic, is the symptom of the unanticipated directions that subaltern formations take below the horizon of official history. The recurrence or 'iteration', each time anew, introduces a deviation into the time-line of the state: the swerve that results from the invocation of the apparently past in a new place displaces historical determination and makes way for alternative cultural logics. (LLOYD, 1999, p. 78)

${ }^{69}$ Termo de análise desenvolvida pelo crítico inglês Raymond Williams que se refere ao modo como as estruturas culturais se desenvolvem socialmente. Williams, Raymond: "For structures of feeling can be defined as social experiences in solution, as distinct from other semantic formations which have been precipitated and are more evidently and more immediately available... The effective formations of most actual art relate to already manifest social formations... that the structure of feeling, as solution, relates." (WILLIAMS, 1977, p. 134)

${ }^{70}$ Original: "Within Heaney's family culture three choices of life might seemed plausible ones for the eldest son: to inherit and maintain the farm; to become a priest; or to become a school master". (VENDLER, 1998, p. 93)
} 
primeiras seções de "Station Island" refletem essa indecisão perante tais elementos postos em conflito. Mais do que colocar tais valores em questão, o poeta os compreende como receptáculos de valores típicos de sua sociedade. Portanto, o encontro com essas personagens - Sweeney, Lough Derg Pilgrim e o padre - combinado com a paisagem social apresentada, o permitirá fazer um salto da poesia que penetra na escuridão, ou seja, a do pântano, para aquela que caminha metaforicamente para claridade, por meio da evocação dos pássaros e do ar.

\section{ECOS DO SILÊNCIO: A MÚSICA DO PASSADO}

De acordo com os conceitos propostos por Heaney em seu artigo teórico "The Makings of a Music", em "Station Island", sua subjetividade poética estaria se afastando da credibilidade adquirida pela experiência, como fizera a lírica de Wordsworth, para a experiência problematizada e levada a dificuldades extremas a partir do metro e da forma, como fizera Yeats. Como postulado por seu artigo, ao questionar a métrica específica que foi originalmente alicerçada em sua experiência de vida, ele estaria se desvinculando do "les vers donnés" (versos dados) e caminhando para o "les vers calcules" (versos calculados) (HEANEY, 1978). Por meio da articulação entre música - forma poética - e experiência artística, Heaney observa que tanto o local geográfico por onde Wordsworth caminha, quanto as suas impressões pessoais sobre a paisagem geográfica cultural moldam sua lírica. Em suas palavras:

a grande força [de Wordsworth] e originalidade como escritor, antes de tudo, provém da confiança na eficácia de sua experiência, da sua corajosa determinação para ériger en lois ses impressions personnels... na fusão original entre som e imagem, na qual Wordsworth pressente as raízes de sua voz poética... encontramos, prefigurados, outros momentos que foram definitivos na sua vida como poeta e que encontraram definição na sua música distintiva (HEANEY, 1991, p. 61)

A partir dessa linha argumentativa, podemos perceber que o poeta absorve o estilo de Wordsworth, principalmente porque sua voz inicial parte da experiência no trato com a terra e com as pessoas - temática que se tornou pioneira na voz do poeta romântico. 
Desta maneira, há nessas quatro primeiras seções de "Station Island" - que constituem o primeiro movimento que nos referimos acima - um retorno ao primeiro contato com a linguagem por meio daquele apelo musical que proporcionou Heaney soar com uma voz distintiva - as fortes aliterações, os pés poéticos bem marcados e definidos e as consoantes da fala gutural da Irlanda do Norte perturbando a harmonia do linguajar inglês. Ademais, esse contato musical com a linguagem está associado a um período muito demarcado em sua vida: a infância. Segundo Heaney, em "Crediting Poetry”, as primeiras sensações de seu lugar, que o levaram à poesia, foram a dissonante musicalidade dos ruídos e das atividades diárias que ocorriam no mundo a sua volta. No relato de sua infância, o autor afirma:

quando eu era o filho mais velho de uma família que não parava de crescer no condado rural de Derry... apreendíamos tudo que estava acontecendo, de fato - chuva nas árvores, ratos no telhado, a chuva de fumaça nos trilhos atrás da casa - mas apreendíamos como se estivéssemos em um sono de hibernação. A-histórico, pré-sexual, em suspensão entre o arcaico e o moderno, éramos suscetíveis e impressionáveis como a água potável que ficava no balde da cozinha: toda vez que o trem passava, fazia a terra tremer, a superfície da água costumava ondular delicadamente, concentricamente e em silêncio completo. Mas não era apenas a terra que tremia para nós: o ar ao nosso redor estava vivo e sinalizando também. (HEANEY, 1998, p. $447)^{71}$

Esse relato impressionista revela, acima de tudo, que Heaney recupera a sonoridade de sua terra natal transpondo a "musicalidade geográfica" do lugar para o início de sua estação.

Dentre essas características, a que mais aflora na primeira parte - o encontro de uma subjetividade mais juvenil com Simon Sweeney - é a predominância do trímetro típico das

\footnotetext{
${ }^{71}$ Parte inicial de "Crediting Poetry" em que Heaney descreve como os sons penetravam em sua consciência. Original: When I was the eldest child of an ever growing family in rural Co. Derry ... we took in everything that was going on, of course - rain in the trees, mice on the ceiling, a steam rain rumbling along the railway line on the filed back from the house - but we took it in as if we were in a doze of hibernation. A-historical, pre-sexual, in suspension between the archaic and the modern, we were as susceptible and impressionable as the drinking water that stood in a bucket in our scullery: every time a passing train made the earth shake, the surface of that water used to ripple delicately, concentrically, and in utter silence. But it was not only the earth that shook for us: the air around and above us was alive and signaling too" (HEANEY, 1998, p. 447, 448)
} 
tragédias sofoclianas, porém ao invés de empregar a típica variação jâmbica, ${ }^{72}$ ele o transforma em outras combinações mais raras como os anfíbracos e os anapestos. Tais experimentações emprestadas da forma trágica são apresentadas logo nas três primeiras estrofes do poema, cuja análise métrica reproduzimos abaixo:
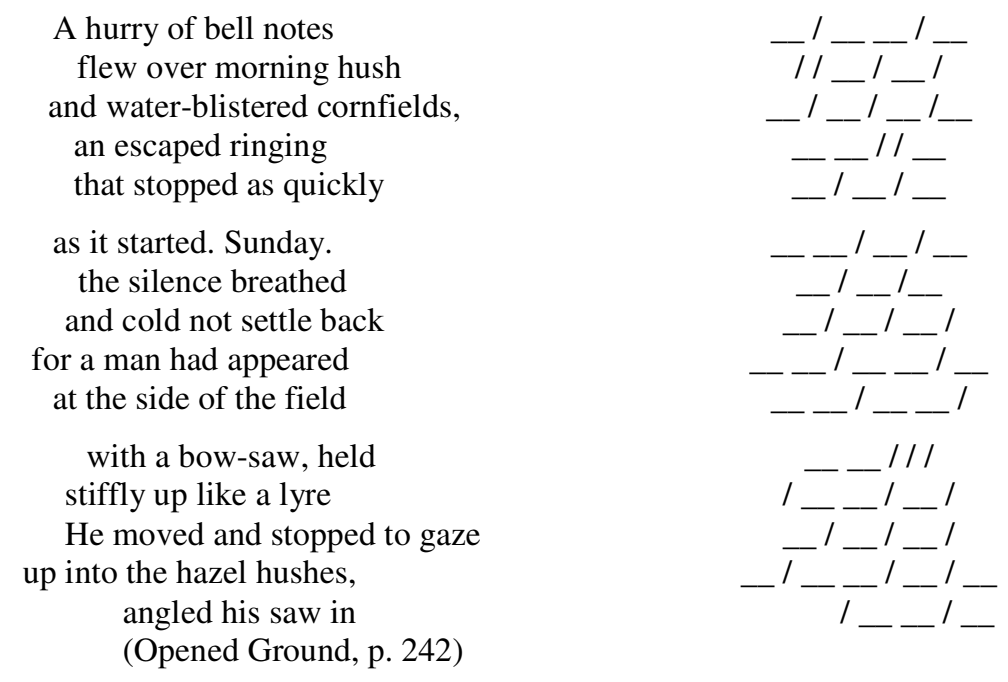

Como podemos observar nas estrofes citadas, entrevemos um começo de intertextualidade com os poetas Gregos, principalmente Sófocles, no que concerne o trato trágico de temas necessariamente prosaicos. Enquanto o poeta inicia sua peregrinação na porta da Basílica de São Patrício (lugar demarcado para os fiéis iniciarem sua penitência), em meio a uma paisagem que se identifica com aquela de sua juventude - "Mossbown, o primeiro lugar, expandido", (HEANEY, 1980, p. 18) ${ }^{73}$ ele observa e se inquieta, juntamente com toda a natureza e os monumentos culturais - os leitos de orações, as igrejas, as procissões seguidas de imagens - a vinda de Sweeney. Contudo, quando se inicia o diálogo entre os dois, o tom descritivo e épico ganha enlevos mais emocionais e populares, pois a métrica torna-se redondilha maior. Portanto, o poeta demonstra como o local e o pessoal são conectados à forma poética.

Esse embate formal revela que Heaney, embora dialogando com Simon Sweeney, está entrando em confronto consigo próprio, ou até mesmo com uma divisão de sua

\footnotetext{
${ }^{72}$ Segundo Aristóteles: "tendo como ponto de partida as fábulas curtas, de elocução grotesca, a tragédia evoluiu até suprimir de seu interior o drama satírico; mais tarde, revestiu-se de gravidade e substituiu o metro tetrâmetro (trocaico) pelo trimetro iambico"

In. Aristóteles. www.charleskiefer.com.br/oficina/textos/Poetica.PDF. 2006, às 14:10hrs.

${ }^{73}$ Original: "Mossbawn". The first place, widened". (HEANEY, 1980, p. 18)
} 
personalidade. Desta maneira, mesmo tendo rejeitado essa figura, ela, na verdade, pelo som homófono ao seu próprio nome e pela evocação do rei mitológico, é exatamente um outro constitutivo em sua formação. Em ambos os casos, seu amigo e a lenda, o diálogo refere-se a uma re-visitação da temática do exílio a partir dos olhos daquele poeta que já ganhou a experiência contrapontística do exílio. Sendo assim, evocar seu passado subalterno é avistar uma possibilidade de criação literária que, até o momento, resistiu à tematização: a possibilidade daquele que foi silenciado voltar a falar. Sem dúvidas essa fala é reproduzida, ou recriada através das observações subjetivas e pessoais do poeta, mas a métrica reconstitui um "ritmo de retorno que é a sobrevivência de imaginações sociais alternativas, em meio às ruínas de culturas despedaçadas e de traços da violência de Estado”. (LLOYD, 1999 , p. 78$)^{74}$ Sendo assim, entrevemos que a subjetividade é composta por aquele silêncio do apagamento da história.

A polifonia, por consequiência, começa a ser demarcada quando o poeta assume a forma dramática trágica para retornar a um passado literário e analisá-lo com os olhos do presente. Logo, o fato de todos os versos que representam as falas do poeta serem redondilhas maiores é extremamente significante, principalmente porque elas retomam o mundo popular e folclórico da Irlanda do Norte, próximo das baladas medievais. A continuação do poema em forma de procissão reforça ainda mais esse clima cristão e convidativo à penitência. Desta maneira, a tonalidade estabelecida nessa primeira parte oscila entre o dramático - quando o eu lírico conversa com Simon - e o mítico, ao colocar em cena algo extremamente irlandês - a peregrinação a Lough Derg. A progressão clássica trágica é, portanto, quebrada pela redondilha maior e interada com a dramaticidade, quase que agressiva, do diálogo.

$$
\begin{aligned}
& \text { pulled back to gaze again } \\
& \text { and more to the next. } \\
& \text { "I know you Simon Sweeney, } \\
& \text { for an old Sabbath breaker } \\
& \text { who has been dead for years } \\
& \text { "Damn all you know", he said }
\end{aligned}
$$

$$
\begin{aligned}
& \frac{-1-1}{1}-1 \\
& --^{1}-1-1 \\
& 11+1+1
\end{aligned}
$$

\footnotetext{
${ }^{74}$ Texto em que David Lloyd comenta sobre o "efeito subalterno" na sociedade irlandesa. De acordo com o crítico, a revelação de estruturas sociais residuais (na terminologia de Raymond Williams) revela os traços contra-hegemônicos da resistência irlandesa. Valho-me de tal teoria para demonstrar que a estética preterida por Heaney carrega algo de residual em sua constituição, e por isso, revela as histórias subalternas que foram suprimidas. Original: "This rhythm of return is that of the survival of alternative social imaginations amid the ruins of shattered cultures and the traces of state violence". (LLOYD, 1999, p. 78)
} 
his eye still on the hedge and not turning his head "I was your mystery man and am again this morning. (O. G., p. 243)

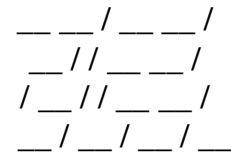

Desta maneira, o diálogo com Sweeney mais do que retomar a versão de história do subalterno, coloca em pauta duas tensões que sempre permaneceram constantes na tradição irlandesa: o embate entre a sensibilidade celta e pagã e a católica escolástica. De acordo com o crítico Neil Corcoran:

o interesse de Heaney em Sweeney vai além da tradução... ele traduz a si mesmo mais intimamente em Sweeney ao... rimar algumas de suas experiências com aquelas do pássaro-rei... ao adaptar algumas das situações, das imagens e dos padrões do texto medieval, e ao empregar uma linguagem figurativa tirada da cópia monástica... Heaney desenvolve a figura de Sweeney como um fora da lei e um estranho, de modo a examinar de forma nova e imprevisível sua relação com as suas origens, em uma família e comunidade católica do norte, com o nacionalismo irlandês e o catolicismo. (CORCORAN, 1997, pp. 21-2) (5 $^{75}$

Concomitantemente ao diálogo com Sweeney, o lugar escolhido para o poema:

Station Island, ou O Purgatório de São Patrício, é uma pequena ilha rochosa no meio de Lough Derg em Co. Donegal que fora, na alta Idade Média, um lugar de peregrinação para católicos. O percurso de três dias (o qual Seamus Heaney percorreu três vezes durante sua juventude) envolve uma penitente rotina de orações, jejum, e caminhadas descalças ao redor dos círculos de pedra ou 'leitos', consideradas destroços do que se acredita serem as antigas celas monásticas. Desde muito cedo, Lough Derg inspirou lendas populares e literatura, em particular, relatos de milagres e visões (CORCORAN, 1996, p. 159$)^{76}$

\footnotetext{
75 Ao mapear a produção literária moderna irlandesa, Corcoran examina como o mito de Sweeney foi retomado por diversas gerações de poetas, romancistas e dramaturgos. Original: But Heaney's interest in Sweeney extends beyond the translation itself... he 'translates' himself more intimately into Sweeney by... rhyming some of his own experiences with those of the bird-king.... By adopting some of the situations, images, and devices of the medieval text, and by employing also a figurative language drawn from the monastic scriptorium... Heaney develops the figure of Sweeney as outlaw and outsider in order to scrutinize newly and unpredictably his relationship with his own origins in a Northern Catholic family and community, with Irish nationalism and Catholicism. (CORCORAN, 1997, pp. 21-2)

${ }^{76}$ Neil Corcoran faz um percurso de análise das obras de Heaney desde Death of a Naturalist (1966), até Station Island (1984), mapeando as principais características de sua poesia, e as explicando a partir de entrevistas e conversas com Heaney. Original: "Station Island, or St Patrick's Purgatory, is a small, rocky isle in the middle of Lough Derg in Co. Donegal which, since early medieval times, has been a place of pilgrimage for Catholics. The three-day pilgrimage (which Seamus Heaney himself made three times in his youth) involves a self-punitive routine of prayer, fasting and barefoot walking around stone circles or 'beds' thought to be the remains of ancient monastic cells. From the very early times, Lough Derg has inspired
} 
Por essa razão, o espaço e a forma poética estão localizados em um espaço fronteiriço em que o diálogo imaginário cria uma força de repulsão e atração: ao ser expulso da nova ordem católica, o Rei Sweeney torna-se um peregrino em sua própria terra nativa; em contrapartida, por uma decisão o poeta sai de sua terra de modo a reencontrá-la novamente.

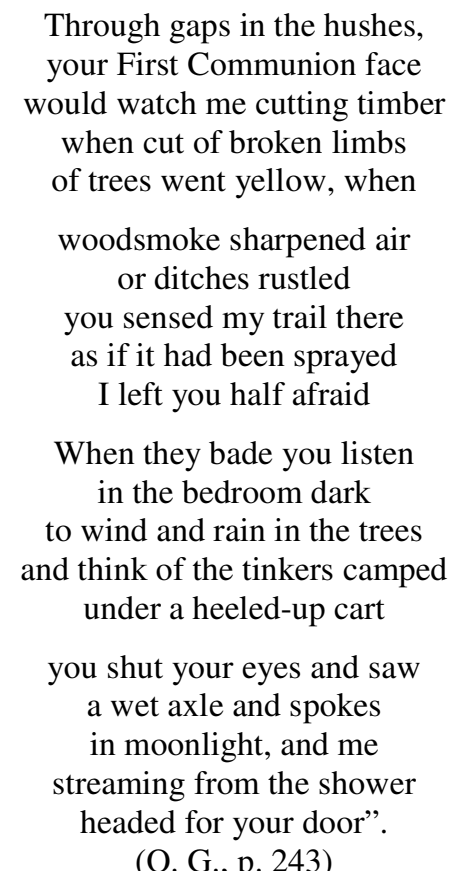

(O. G., p. 243)

Além de ser um dos alter egos do poeta, Simon Sweeney é um personagem verídico que pertencia a uma família de funileiros, e era amigo do poeta (ARANTES, 1998, p. 333). Quando Heaney maduro, já estabelecido como um grande poeta, retoma sua infância e se enxerga através dos olhos desses dois personagens, significa que ele pretende recuperar a "consciência insurgente" de sua história, e compreender "a escala diminuta do funcionamento do mundo filosófico subalterno" (SPIVAK, 1987, p. 214). Portanto, a dicotomia entre o poeta mais distanciado da realidade, e aquele mais próximo a ela começa a ser resolvida e não provoca tanta angústia como visto em sua poesia mais recente. Após ouvir calado e atento às lembranças que o amigo recorda, o poeta se volta para a procissão e segue em cortejo juntamente com todos os outros peregrinos - principalmente as mulheres 159). 
de xales pretos. Como um nômade da Idade Média, visto que a métrica volta a ser redondilha maior quando o poeta se refere a si mesmo, o poeta vê-se envolvido e absorto pelos passos e pelo ritmo frenético das orações, como se fosse algo que ele próprio não previra.

Novamente, Sweeney o exorta para ficar "puro" (livre, afastado, limpo - "clear") de todas as procissões, uma vez que o excesso dessas o desviaria dos caminhos artísticos e o traria para a vocação eclesiástica. Sem sucesso, o eu poético infantil permanece no meio de todos os fiéis ouvindo o dobrar dos sinos e sendo levado pelas práticas religiosas. Entretanto, ele não é mais o mesmo, pois os ideais de Sweeney se infiltraram em sua subjetividade. A questão da escolha volta novamente a ocupar a mentalidade do poeta, pois ele não pretende se render às posições que estão disponíveis na sua sociedade, mas renovar tais tradições. Heaney reafirma e amplia os experimentos artísticos feitos pelo poeta romântico Wordsworth:

a medida em que os seus pés poéticos repetem suas passadas, a terra parece ser um moinho girado por ele próprio; o grande rolo diurno é sentido através da batida poética e o mundo se move como uma roda d'água ordenada pela cadência de sua voz. (HEANEY, 1980, p. 68) ${ }^{77}$

Essa primeira parte de "Station Island" reflete como ele traduz o mundo por meio da métrica.
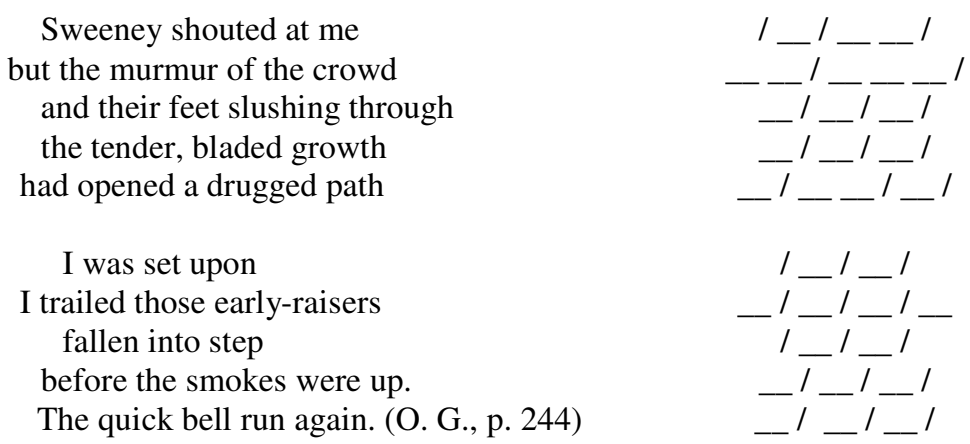

Se por um lado a métrica é ordenada polifonicamente de acordo com a circunstância psicológica do autor, essa, por outro lado, ao contrário dos estados de espírito bucólicos e

\footnotetext{
${ }^{77}$ As his poetic feet repeat his footfalls, the earth seems to be a treadmill that he turns; the big diurnal roll is sensed through the poetic beat and the world moves like a waterwheel under the fall of his voice. (HEANEY, 1980, p. 68)
} 
melancólicos de Wordsworth, propõe a divisão identitária de um poeta cujas aspirações pretendem empreendimentos maiores do que as escolhas que são colocadas para ele em sua juventude. Desta vontade de promover um distanciamento crítico em relação à terra de origem, e expressando essa tensão na própria forma poética, surge o diálogo com seu ego mais velho e, por conseguinte, de como foi necessário ele se desvincular dos estereótipos irlandeses, sem perder a identificação com o sentimento popular. Conseqüentemente, há uma polifonia em forma de fuga da voz primeira do poeta e daquela que ele está progressivamente encontrando para problematizar sua experiência de vida e, desta maneira, continuar com uma lírica que seja mais verdadeira ao subalterno reprimido.

A longa caminhada continua, porém na segunda parte do poema, o encontro será mais intenso, pois Heaney coloca em cena o personagem Lough Derg Pilgrim do escritor Romântico irlandês William Carleton (1794-1869). A métrica, por sua vez, sofre uma transformação: os trímetros (ou redondilhos) de cinco versos são substituídos por tercinas de dez sílabas poéticas. Esse rearranjo formal é revelador, uma vez que ele sai de um metro ligado ao universo dramático grego revestido de uma roupagem irlandesa popular, e começa a penetrar na representação cultural do decassílabo. Segundo Anthony Easthope (EASTHOPE, 1983), o pentâmetro jâmbico é uma criação discursiva poética típica da tradição inglesa, porque foi constituído exatamente no mesmo período em que a lírica estava se formando com Chaucer, portanto ele confere ao metro um senso ideológico de identidade e pertencimento à nação. Na verdade, tal mudança representa a saída de um mundo ligado ao familiar, ao doméstico e ao emocional, para penetrar naquele que pertence à égide da cultura imposta e da dominação econômica e cultural: o poeta assume a sua condição de colonizado e, através de pequenas cenas - quase que cinematográficas representa as mais evidentes divisões e problemas sociais que essa ligação colonial perpetua.

Contudo, esse retrato será confuso e fragmentado principalmente porque toda prefiguração de sentimentos posta pelo segundo momento representa uma consciência subalterna proveniente do inconsciente coletivo. Heaney começa, portanto, a esboçar uma tentativa de escrita que, por ser atormentada pelas vozes passadas, "adere à experiência coletiva tanto mais intimamente quanto mais rebelde el[a] se torna à sua expressão lingüística objetivada". (ADORNO, 1970, p. 191) Sendo assim, o rearranjo formal 
composto por sua poética representa a história epistemológica do imperialismo na Irlanda como uma série de "interrupções descontínuas" (SPIVAK, 1999) em que a consolidação da subjetividade é perpassada por um passado que se atualiza no presente da objetivação lingüística. $\mathrm{Na}$ continuação do poema observamos o poeta assombrado pelo fantasma de Lough Derg Pilgrim que, metaforicamente, o faz buscar respostas para sua escolha de ser escritor.

De acordo com Declan Kiberd, William Carleton, através da persona literária Lough Derg Pilgrim reconstrói uma possibilidade de escrita que vislumbra o indivíduo dentre uma vasta multidão e dramatiza essa experiência. Como o crítico afirma:

O objetivo de Carleton [era] produzir uma escrita que, sem recortes, retribua a experiência de todas as pessoas escondidas... a questão de articulação e desarticulação é central para Carleton... Para [ele] a peregrinação a Station Island revelou não somente a impossibilidade da vocação para o sacerdócio católico, mas também para sua vocação a escrita. Conseqüentemente, ele foi alguém para quem a experiência era incompleta até que ele escrevesse sobre ela. (KIBERD, 200, p. 268) ${ }^{78}$

Podemos, portanto, entrever uma semelhança entre o projeto de Carleton e de Heaney, pois a sua escrita coloca na constituição formal, outras histórias individuais. Ademais, a presença do peregrino o afeta profundamente, por relacionar arte à comunidade e religião - essa última como faceta dúbia de sua personalidade visto que penetra, de forma indiscreta, na política de seu país, e as suas trágicas consequiências como terrorismo e morte.

A religião sempre foi uma fonte de inspiração para Heaney, ora para refletir sobre sua própria personalidade, ora para analisar a situação de violência de seu país, e ora para descobrir a si mesmo. Porém, essa é fonte de grandes desassossegos e inquietações:

Minha linguagem e minha sensibilidade anseiam por admitir uma espécie de dimensão religiosa ou transcendente. Mas a realidade persiste: não existe

\footnotetext{
${ }^{78}$ Original: Carleton's aim [was] to produce a writing that seamlessly renders the experience of the whole, hidden people... The question of articulacy and inarticulacy is central to Carleton... For [him] the pilgrimage to Station Island revealed not only the impossibility of a vocation to the Catholic priesthood but also the urgency of his vocation to writing. Thereafter, he 'was someone to whom experience was incomplete until he'd written for it'. (KIBERD, 200, p. 268)
} 
céu, vida depois da morte do jeito que nos foi permitido, e não existe Deus. (HEANEY APUD NOLASCO, 1996) ${ }^{79}$

Carleton também demonstra esse descontentamento com relação à religião quando, após escrever Lough Dergh Pilgrim, converte-se ao Protestantismo e deixa de lado a militância católica. Com isso, podemos observar que, mesmo sem o desejo de abandonar a religião, Heaney confere ao poema ares de insatisfação e falta de confiança, uma vez que o peregrino torna-se seu alter-ego.

Outro paralelo que impele o poeta a se identificar e receber conselhos de Carleton é seu conhecimento sobre a classe com a qual o poeta não pretende se dissociar - como observado pelo conselho de Sweeney. De acordo com Roger McHugh e Maurice Harmon:

O poder literário de Carleton estava na sua intimidade com o tema. Ele viveu em choupanas... ele conhecia em primeira mão a fome de terra dos seus desprovidos e a violência que poderia surgir de uma terra semeada por trabalhadores sem esperança. Algumas de suas melhores histórias também demonstram essa violência. (MCHUGH, HARMON, 1982, p. 92). ${ }^{80}$.

A partir dessa característica da literatura de Carleton, Heaney observa atentamente sua sociedade e começa a selecionar as nuanças melódicas que o levarão a compor uma estética imanentemente violenta que, em sua constituição, foi moldada por uma subjetividade "epistemologicamente fraturada" (SPIVAK, 1993). Essa fratura, por sua vez, é originada a partir da diferença entre o "poder" e o "saber" que, na leitura de Spivak sobre Michel Foucault, estaria relacionado às estruturas cognitivas do sujeito colonial: se por um lado o "poder" de governar a terra e a si mesmo estaria relegado à permissão, ou seja, o verbo "poder" no sentido de submissão, por outro lado, o "saber" seria o produto do conhecimento sobre essa relação de subordinação. Portanto, na obra de Heaney, a substância discursiva da dupla ligação (“double-bind”) do "poder/saber” é a apropriação

\footnotetext{
${ }^{79}$ Artigo brasileiro que aborda a poesia de Heaney devido ao seu Prêmio Nobel de Literatura. (HEANEY APUD NOLASCO, 1996)

${ }^{80}$ Capítulo no qual o autor foca a busca dos autores irlandeses na literatura que estivesse relacionada aos assuntos nacionais. Carleton era um dos mais interessados na localidade, principalmente porque foi o primeiro a ter a profissão de autor: "the work of William Carleton was concerned with Ireland. He was the first homebased Irish writer of fiction to support himself for the greater part of his life, however precariously, by his pen”. (p. 90). Original: Carleton's literary power was intimacy with his subject. He had lived in... cabins he knew at first hand the land-hunger of landless men and the violence which could flower suddenly in a land tilled by labourers without hope.Some of his best stories convey that violence well. (MCHUGH, HARMON. 1982, p. 92)
} 
das estruturas lingüísticas da cultura inglesa que reprimiu a sua terra política e historicamente. Nesse sentido, ambos os autores tentam livrar-se do poder relegado à força e à violência, mas pretendem, de fato, produzir algo a partir delas, ou seja, representar a lacuna existente entre arte (abstração) e história (prática) ${ }^{81}$ Assim, observamos o diálogo como um lugar de embates entre sujeitos que lutam metaforicamente contra as forças externas dentro de sua própria subjetividade.

Nesse diálogo - que se aproxima muito da forma dramática, visto que o "narrador" quase não interrompe a linha argumentativa dos dois "personagens" - o poeta deixa a coloração submissa - "poder" - e caminha para aquela de um artista consciente das nuanças identitárias da Irlanda do Norte - "saber". Nesse sentido, ele recupera formas já estabelecidas, ou pelo menos influenciadas pela cultura do império, de modo a construir estruturas formais que relacionem seus conflitos pessoais aos de sentimentos de sua sociedade. Entretanto, nesse embate, ele compreende o quanto a violência discursiva do "poder" cria um processo de negação e aceitação do outro, característica que gera o hibridismo formal ${ }^{82}$, visto que o metro através do qual ele fala, varia entre o pentâmentro jâmbico e a redondilha maior. É importante atentar para o fato de que a fala do autor está em redondilha menor, apesar de o verso ser decassílabo.

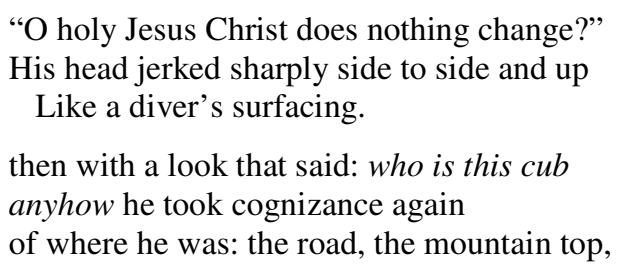

(O. G., p. 245)

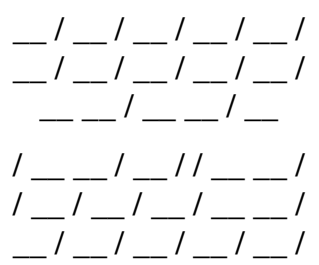

Desta maneira, a segunda intertextualidade que surge nesse poema é também relacionada à forma, estressando ainda mais o caráter orquestral de sua composição: se no primeiro movimento o poeta quebra o trímetro com a redondilha maior, aqui ele subverte o decassílabo jâmbico com outros pés poéticos, e com a redondilha maior. Logo, o metro

\footnotetext{
${ }^{81}$ No texto "More on Power/Knowledge", Spivak faz a distinção entre as categorias de Foucault do poder e do saber. Enquanto o primeiro estaria associado ao poder colonial que imprime a sua força nas sociedades dominadas, o segundo seria a apropriação desse poder pelo subalterno, ou seja, o saber que o levaria à resistência e à ação. Para a crítica, sociedades pós-coloniais apresentam concomitantemente ambas as relações em suas estruturas culturais. (SPIVAK, 1993, pp. 25 - 51)

${ }^{82}$ Quando nos referimos a hibridismo formal estamos nos remetendo ao conceito de Stuart Hall e David Lloyd que apresentamos em nossa introdução. Enquanto um foca na cultura, o outro, foca na história.
} 
medieval é o elemento de estranhamento com o qual o poeta rompe a lírica. Necessariamente, a quietude poética deve ser rompida, principalmente porque o artista está capturando subjetividades em conflito no próprio interior de seu lócus enunciativo. No momento em que ele faz essa combinação, ele abre espaço para uma "força da diferença cultural [que] é... a violação do limite de espaço significante, ela permite no próprio nível do discurso uma contra-divisão de objetos, usos, significados, espaços e propriedades". (BHABHA, 2003, p. 97) ${ }^{83}$ Ao desrespeitar o uso clássico da forma que deu unidade ao projeto imperial britânico - o metro Shakespeariano - o autor demonstra que a sua versão da história - daqueles que foram dominados - deve ser levada em consideração. Portanto, é aberto, através da forma, um caminho pela qual a história colonial é contada.

Nesse sentido, a relação entre "choque" e "experiência" benjaminianos é encenado, e o que nos é apresentada é uma "consciência situacional", "em que o contar da história individual e a experiência individual não podem deixar de, por fim, envolver todo árduo contar da própria coletividade". (BHABHA, 2003, p. 200) Por esta razão, nos próximos versos, o poeta se sente na obrigação de justificar suas características particulares de acordo com o comportamento de sua comunidade. Ademais, ao acoplar ao metro, a experiência coletiva, Heaney desconstrói a posição cultural do jâmbico, pois, segundo o crítico Anthony Easthope:

o Pentâmetro Jâmbico corresponde à oposição ideológica entre 'social' e 'individual', uma oposição que pensa a sociedade como uma 'necessidade' contra e na qual o indivíduo encontra sua liberdade. (EASTHOPE, 1983, p. $68)^{84}$

Consequientemente, a revelação poética se dá por meio do aprisionamento da forma e pela consciência de que a subjetividade lírica é igualmente política, pois o poeta faz parte de uma sociedade composta por valores dúbios e contrastantes.

\footnotetext{
${ }^{83}$ De acordo com Bhabha, os deslocamentos diaspóricos e minoritários criam uma linha subversiva, no momento em que, na estratégia de ambivalência, o "eu" e o "outro" se fundem. Nesse caso, essa estratégia de resistência é conseguida pela métrica. (BHABHA, 2003, p. 97).

${ }^{84}$ Capítulo do livro em que Easthope define o pentâmetro jâmbico como um fetiche cultural que exclui e divide a cultura em alta e baixa: "Once established as national poetic institution pentameter becomes a hegemonic form. It becomes a sign which includes and excludes, sanctions and denigrates, for it discriminates the 'properly' poetic form the 'improperly' poetic". (p. 65). Original: the iambic pentameter corresponds to the ideological opposition between the 'social' and the 'individual', an opposition which envisages society as a 'necessity' against and within which the individual finds his or her freedom. (EASTHOPE, 1983, p. 68)
} 
A ambigüidade, em termos de articulações poéticas, provém do fato do poeta encarar seu lugar de origem segundo duas lógicas distintas: "um é vivido, inculto e inconsciente, o outro aprendido, culto e consciente. Na sensibilidade literária, ambos, dentro de uma tensão consciente e inconsciente, podem co-existir". (HEANEY, 1980, p. $131)^{85}$ No caso deste poema, vemos essas duas forças sendo postas em choque, uma vez que o autor, pretende compreender o porquê determinados traços de personalidade são insistentes, embora não desejados. Sendo assim, ele descreve sua comunidade a Carleton quando esse o acusa de ser defensivo, embora espontâneo. Sua métrica é contrária, quebrada e disjuntiva com relação àquela produzida pelos ingleses e pelo seu compatriota irlandês. Desta quebra provém a sua polifonia dissonante e sincopada: seus versos variam de um metro jâmbico perfeito, para outro completamente invertido, para o troqueu, dentre outros.

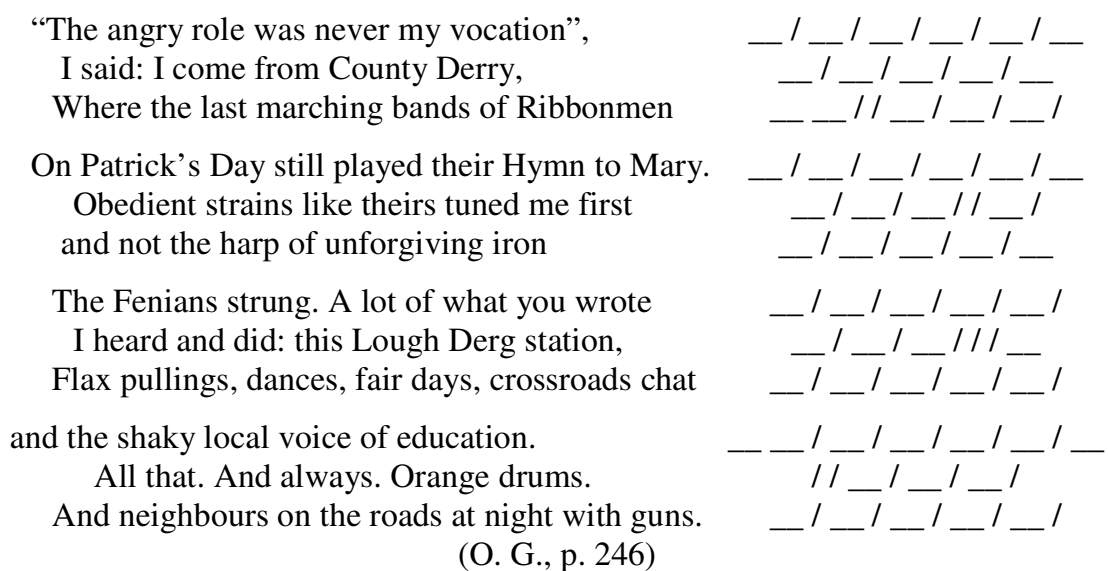

Ao longo desses versos também podemos observar as tradições religiosas e folclóricas acompanhadas pelos "tambores de Orange" protestantes e às "harpas de ferro" dos fenianos católicos. Entendemos, portanto, que o poeta nasce em meio a essas práticas culturais e também às disputas e conflitos que acontecem nos confrontos entre unionistas e libertários. De acordo com Máiréad Nic Craith:

as paradas Orange dão uma ênfase especial ao século XVII em Ulster, e comemoram eventos como o massacre de 1641, o cerco da cidade de Derry e a vitória do rei protestante William de Orange na batalha de Boyne. Em uma carta ao Belfast Telegraph, um dos escritores sugere que no dia 12 de Julho,

\footnotetext{
${ }^{85}$ Original: one is lived, illiterate and unconscious, the other learned, literate and conscious. In the literate sensibility, both are likely to co-exist in a conscious and unconscious tension. (HEANEY, 1980, p. 131)
} 
os Oranges não só comemoram uma significante vitória militar e política, mas também uma grande libertação da escravidão romana, assim como os judeus comemoram todo ano sua libertação do Egito. (CRAITH, 2002, p. $33)^{86}$

Assim sendo, parece que a própria questão de um decassílabo quebrado está associada a esse evento histórico pois coagido, o autor não consegue "imitar" o colonizador de uma maneira perfeita, mas faz desta a sua arma para poder forjar sua própria subjetividade.

Ao ouvir tais explicações de Heaney, Carleton responde de maneira desengonçada e sem originalidade, "I know, I know, I know, I know", o que faz o poeta continuar em suas flutuantes digressões sobre sua casa e os elementos naturais que a envolviam. É como se através de um fluxo de consciência poético - como ele já fizera em "The Tollund Man" (Wintering Out 1972) $)^{87}$ - os dois artistas estivessem ponderando elementos distintos: enquanto Heaney se volta ao doméstico, Carleton começa a dar conselhos sobre a linha de conduta que ele deve seguir. Se por um lado as duas mentes estão em fluxos diferentes, por outro lado, são paralelas, pois o poeta está novamente colocando cenas e espaços distintos no mesmo plano. A pequena "cena" torna-se atemporal e, acima de tudo, um avanço rumo à poesia futura que o artista pretende seguir, aquela que seja plural, múltipla, consecutiva e simultânea, mas que produza algo maior - "saber". Como Heaney próprio diz: "Station Island é uma seqüência com partes separadas, que quando juntas, formam uma coisa maior. Então, há movimentos e tudo mais”. (HEANEY, 2006) ${ }^{88}$ Esses movimentos predizem, não somente a multiplicidade, mas também o enfoque melódico, de toda a composição.

\footnotetext{
"I know, I know, I know, I know", he said

"but you have to try to make sense of what comes.

Remember everything and keep your head".
}

\footnotetext{
${ }^{86}$ Estudo sociológico sobre a constituição da Irlanda do Norte, desfazendo mitos, e se baseando em estatísticas quantitativas. Original: Orange parades place a special emphasis on the seventeenth-century Ulster, and commemorate events such as the massacre of 1641, the siege of the city of Derry, and the victory of the protestant king William of Orange at the Battle of the Boyne. In a letter to the Belfast Telegraph, a writer suggests that on the $12^{\text {th }}$ of July, Orangemen "not only commemorate a very significant military and political victory, but a great deliverance from Roman slavery, in much the same way as the Jews each year commemorate their deliverance from bondage in Egypt. (CRAITH, 2002, p. 33).

${ }^{87}$ A análise completa de "The Tollund Man" (Wintering Out, 1972) encontra-se em Annunciação, Viviane Carvalho da, 2004/ 2005, USP.

${ }^{88}$ Entrevista de Heaney em que ele discorre sobre os temas mais importantes em sua poesia. Original: 'Station Island' is a sequence with separate finished bits put together to make a bigger finished thing. So there are movements in it and so on. (Heaney, S. http://www.lannan.org/lf/rc/event/seamus-heaney/., 2006, às 11h30.)
} 


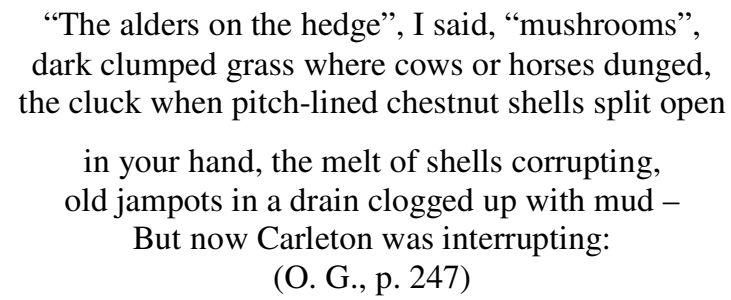

$\mathrm{Na}$ última parte do poema, em que Carleton dá seus conselhos finais e define o significado de ambos, há um clima de silêncio semelhante uma pausa que se segue após um momento de rememoração: a conclusão de que eles podem ser simbolizados como uma "minhoca da terra". Embora pareça extremamente grotesca, se observada de um outro ângulo, possui uma grande verdade, uma vez que ele digere todas as estruturas sociais e culturais, para depois poder escrever. O poeta também, por conseqüência, digere Carleton, que nesse momento do poema, torna-se uma parte de sua personalidade e o aconselha. Nesse sentido, há dois processos digestivos sendo colocados em pauta: o da experiência social e o da própria intertextualidade literária. Logo, compreendemos que Heaney, além de não dissociar sua composição nem de uma, nem de outra, ainda as funde em um processo artístico.

\footnotetext{
"All this is like a trout kept in a spring or maggots sown in wounds another life that cleans our element.
}

We are earthworms of the earth and all that has gone through us is what will be our trace. He turned on his heel when he was saying this And headed up the road at the same hard pace.

(O. G., p. 247)

Voltando à questão do artista como aquele que possui seu trabalho galgado na experiência coletiva, compreendemos que a beleza poética na imagem da minhoca está no fato dela, como György Lukács argumentou sobre a poesia primitiva:

part[ir]... do fato fundamental da importância da práxis; represent[ando] o sucesso e o fracasso das intenções humanas na prova da experiência e decorre[ndo] sua profunda significação... essa poesia continua viva, por colocar no centro da representação exatamente fato[s] fundament[ais] da vida humana (LUKÁCS, 1965 , p. 58) ${ }^{89}$

\footnotetext{
${ }^{89}$ Lukács coloca a diferença de narrar e descrever em termos da práxis. Enquanto o primeiro constitui uma experiência que reflete a coletividade da experiência histórica - como a poesia primitiva com a qual ele traça um paralelo - o segundo representa uma atitude reificada da civilização burguesa que foca na importância dos
} 
Por essa razão, o poeta coloca na forma poética o diálogo com a experiência concreta social, acoplada à tradição literária que também sofreu com a mesma questão colonial e identitária da qual ele se vê diante. O último verso, em que o poeta observa Carleton desaparecer no horizonte, é um fio condutor que o leva para segunda parte, pois ele está apenas começando seu caminho, atentando aos leitores, e a si mesmo, que este será duro. O pronome "mesmo" refere-se à dureza da história e das relações entre tradições antagonísticas que ele terá de enfrentar. Além do mais, seu passo também deverá ser duro, o que projeta já uma visão solitária de exílio, afastamento, culpa e cobrança perante a sua atitude.

\section{A MÚSICA DAS IMAGENS SURREALISTAS}

$\mathrm{Na}$ terceira parte do poema observamos Heaney em profunda atitude de contemplação e oração. Na igreja, embalado pelo constante murmúrio de preces, o poeta entra em um devaneio inconsciente que produz imagens fantásticas, como uma onda presa em concha segurando o teto da igreja, ninhos de pássaros e grama pisada onde ele encontrara pêlos de seu cachorro desaparecido. Isto demonstra que Heaney tem no ritmo das ladainhas uma fonte de inspiração para escrever, como se essas tivessem vida própria e o ajudassem a despertar associações absurdas - as quais, por vezes, retomam as composições surrealistas de caráter onírico e desconectadas. Essa nova experimentação com técnicas e associações, na verdade, são ecos de seu exílio na Espanha retratado pelo poema "Summer 1969" (North, 1972) - mais precisamente em Madri, contemplando os quadros do Museu do Prado - em que ele entra em contato com García Lorca e seu universo cultural.

Contudo, ao invés de trazer à tona o colorido do poeta espanhol, o poeta retoma a palidez e quietude de seu mundo irlandês, em que o som das súplicas produz imagens de exílio, carregadas com uma certa dose de nostalgia. Enquanto o mar é um primeiro passo para que ele rompa com esse universo, os pássaros reproduzem exteriormente um desejo interior de voar para além dessas determinações, e acima de tudo, compreender o

objetos e não das interações entre indivíduos. Embora a intenção do crítico seja focar na narrativa, sua pequena digressão sobre poesia, parece-nos plausível no contexto do poeta. (LUKÁCS, 1965, p. 58) 
significado das mesmas a partir de uma ótica distanciada. Combinado com as imagens de exílio, um grande tom de mistério envolve esse poema, como se o artista quisesse capturar, como Virginia Woof argumenta sobre Joyce:

por um momento uma mente... em um dia qualquer/interessado em revelar a luz bruxuleante daquela íntima chama que flameja suas imagens no cérebro com o intuito de preservá-la (WOOLF, 1957, p. 187)

Em um dia aparentemente atemporal, mesmo estando o poeta inserido na peregrinação, as imagens que Heaney projeta parecem chamas oscilantes, que vão de um lado para o outro, revelando desejos íntimos e avançando perdas futuras, sendo que o último verso fala de ausência. Sendo assim, toda a passagem adquire contornos oscilantes e fluídos, em que tudo que é construído parece, ao mesmo tempo, fugaz e transitório.

Igualmente, a métrica deste trecho não é bem definida, parece hesitante e dúbia: decassílabos jâmbicos dividem espaço com eneassílabos, octossílabos e, até mesmo, alexandrinos. Enquanto o primeiro verso fala de um hábito após a morte, o seguinte retorna a terra mimetizando os sons de rosários e murmúrios. Parece-nos muito instigante essa escolha, pois o poeta deixa o mistério da vida após a morte, para poder ouvir os sons provindo da terra - como Antonio Cândido afirma "a terra só o [poeta] ouve depois que [esse] ouviu à Terra" (CANDIDO, 2002, p. 166). Há, nesse sentido, uma relação identificatória sendo colocada no centro do poema, pois as comparações e metáforas que o autor traz à tona não são puramente frutos de seus desejos, mas impulsionadas pela cultura na qual ele fora criado. A evocação da morte da menina que ele conhecera é também significativa, uma vez que, nessa parte, aquele Heaney imaturo e pueril também está para morrer, e em seu lugar entrará outro mais atento às questões para além da ilha.

Nas três primeiras estrofes, o poeta evoca quadros ainda relacionados à igreja, pois as conchas e os mexilhões estão afixados no cenário interno do oratório. Contudo, essa transposição entre o local e o exílio causa um estranhamento, principalmente porque é como se a força da onda marinha, além de segurar o teto com seu vigor, imprimisse cores e apetrechos no interior de onde os fiéis fazem suas orações. Como conclusão, sentimos que

\footnotetext{
${ }^{90}$ A escritora inglesa, por meio de seus ensaios, ressalta as principais características do romance moderno. Dentre essas, James Joyce possui as que representam melhor o movimento. Original: for a moment, [a]... mind on an ordinary day/concerned [...] to reveal the flickerings of that innermost flame which flashes its images through the brain, and in order to preserve it. (WOOLF, 1957, p. 187)
} 
o poeta pretende se libertar daquele mundo escuro e sem vida invocado por aquele minuto, mas, sua capacidade de fazê-lo ainda é parca. Ao extinguir a imagem literal do santuário, o autor se auto-anula também, assim como Theodor Adorno afirma:

o sujeito, que no Surrealismo age de maneira muito mais aberta e desinibida do que nos sonhos, concentra sua energia justamente na auto-extinção, o que no sonho não requer nenhuma energia; mas por isso mesmo tudo aparece mais objetivamente, por assim dizer, do que no sonho, onde o sujeito, ausente desde o início, dá novas cores e permeia tudo o que encontra nos bastidores. (ADORNO, 2003, p. 136) ${ }^{91}$

Para o filósofo, mesmo estando na esfera do sonho, o sujeito ainda continua condicionado pela realidade, pois o desejo de liberdade é uma constante no mundo racionalizado pela mercadoria. Assim, as teorias que levam em consideração apenas o aspecto psicológico do Surrealismo, não conseguem abarcar a esfera histórica desse sujeito. $\mathrm{Na}$ próxima estrofe, a evocação da garota morta, cujo hálito produz pérolas, evoca justamente a extinção dessa subjetividade que não se afasta das efusões religiosas e nacionais, ou seja, da materialidade proposta por sua sociedade.

I knelt. Hiatus. Habit's afterlife...

I was back among beads clicks and the murmurs

from inside confessionals, side altars

where candles died insinuating slight

inmate smells of wax at body heat.

There was an active, wind stilled hush, as if

in a shell the listened-for ocean stopped and a tide rested and sustained the roof.

A seaside trinket floated then and idled in vision, like phosphorescent weed,

a toy grotto with seedling mussel shells and cockles glued in patterns over it.

pearls condensed from a child invalid's breath into a shimmering ark, my house of gold that housed the snowdrop weather of her death long ago. I would stow away in the hold. (O. G., pp. 247-8)

\footnotetext{
${ }^{91}$ Adorno desenvolve uma série de conceitos sobre o Surrealismo, em cujo cerne está a idéia de que, como vanguarda, esse movimento conseguiu ser a última e genuína corrente revolucionária - após a euforia dos anos vinte. Mesmo discorrendo sobre o aspecto ideológico e mercadológico da arte, acreditamos que as teses de Adorno são válidas para Heaney porque demonstram um sujeito cindido. (ADORNO, 2003, p. 136)
} 
As estrofes que se seguem, anunciam o medo do poeta perante a morte e ele se esconde nas lembranças de quando ele tocava em ovos de pássaros, e esses, como o nome da garota morta, afixavam-se a ele e não conseguia ir embora. Vemos, então, uma luta subjetiva em que o menino precisa morrer, mas que também quer se ver livre da morte e voar como um pássaro. Novamente, o pássaro indica uma liberdade que ele não possui, assim como aquela proporcionada pela estética surrealista. Voltando aos apontamentos de Adorno, compreendemos que o momento subjetivo se dá na montagem de imagens inusitadas que, apesar de se manterem em dissonância com a realidade, parecendo algo diverso da sociedade, mas que transitam entre a esquizofrenia e a coisificação. Em suas palavras, "as imagens... do Surrealismo são as de uma dialética da liberdade subjetiva em uma situação de não-liberdade objetiva" (ADORNO, 2003, p. 138). Se por um lado, ele quer ser livre, a criança morta e as orações em razão de sua morte, não conseguem liberálo, pelo contrário, transformam-no em um objeto que deve compreender os "choques" da sua identidade, e como tais choques têm uma relação íntima com a sociedade colonial da qual faz parte.

Portanto, a procura subjetiva por liberdade não passa de uma parcial liberdade, visto que o sujeito é condicionado pelos outras facetas de sua personalidade. No momento em que ele pensa em andar em círculos, saindo, deste modo, da oração comportada e quieta, ele também sente esse impulso libertário. Porém, no âmbito dessa parte do poema, ele não conseguirá, principalmente porque ainda está preso à sua comunidade e por esse ser o início da estação que o leva metaforicamente para fora da Irlanda.

\footnotetext{
of our big oak sideboard and forage for it

laid past in its tissue paper for good. It was like touching birds' eggs, robbing the nest of the world wreath, as kept and dry and secret

as her name which they hardly ever spoke but was a white bird trapped inside me beating sacred wings when Health of the Sick fluttered its pray for us in the litany

A cold draught blew under the kneeling boards I thought of walking round and round a space utterly empty, utterly a source, like the idea of sound.
} (O. G. 248) 
O final dessa terceira parte permanece obscuro, uma vez que a ausência final não é preenchida pelo encontro com o cão perdido, através da sinédoque daquilo que parecem ser seus pêlos - sugerindo novamente morte e destruição. Desta maneira, compreendemos que a terceira parte do poema demonstra uma vontade de rompimento com essas tradições e uma ânsia por liberdade, contudo, essa só poderá ser atingida no final do poema. A questão da evocação ao Surrealismo denota a falta de liberdade dessa etapa de sua experiência de vida. Esse aprisionamento produz uma polifonia da extinção da privação em meio a ritmos dissonantes de orações e preces - que, por sua vez, são produtos dessa sociedade dissonante e contraditória. Heaney adquire consciência da necessidade de encontrar sua própria voz poética, porém também entende que precisa compreender as vozes da terra, ou seja, não só do povo, mas também da natureza e de como ela fora demarcada e modificada com os investimentos coloniais. Desta forma, todos esses fatores contribuem para o poeta representar a ausência e aniquilamento da sua personalidade ingênua.

\footnotetext{
or like the absence sensed in a swamp-fed air above a ring of walked-down grass and hushes where we once found the bad carcass and scrags of hair of our dog that had disappeared weeks before.
}

(O. G., p. 248)

O tom descritivo do poema, aliado a impressões vagas sobre a natureza dos objetos no interior da igreja retomam a idéia de uma objetificação progressiva do ser que, quando mediado pela constelação de entidades que o constitui, torna-se uma não-identidade. Desta maneira a:

a diferença entre sujeito e objeto não deve ser negada, por sua vez, nem os dois constituem uma dualidade última, nem há uma unidade última que se oculta por de trás deles. Eles tanto constituem um ao outro quanto... [e] separam-se um do outro (ADORNO APUD DEWS, 1973, p. 176)

Portanto, no poema, sujeito e objetos são essa sinédoque adiada, que se apresenta como uma metonímia, ou seja, a liberdade do sujeito se instaura na não liberdade, que adia a sua transcendência e o faz retornar esvaziado a sua estação primeira.

A ausência de liberdade demonstrada pelo poema pode ser, então, relacionada com a continuação na parte IV: uma ponte transitória para o poeta dissociar-se deste mundo naturalista e seguir em direção ao seu exílio. Por conseguinte, esse deslocamento tem início 
na quarta parte, cujo tema, embora ainda focando na questão religiosa, é revertido para como o familiar é colocado no estranho. Em outras palavras, ao retratar um jovem padre que tem a experiência de fazer seus ritos longe de casa - nas missões - Heaney desloca igualmente sua subjetividade, visto que ele fora um artista que experimentou escrever versos fora de seu lugar de origem. Nesse novo desdobramento temos um artista que retoma, portanto, os primórdios da atividade poética e a aproxima da questão religiosa. Desta maneira, é possível até traçarmos um paralelo entre a função primitiva do poeta, como adivinhos e curandeiros (MCHUGH; HARMON, 1882, p. 32), com essa nova roupagem, do padre que leva a cura espiritual aos demais povos. Contudo, nesse poema o resultado dessa experiência é ainda duvidoso, pois ambos o eu lírico e o padre parecem estar incertos no que diz respeito à cultura da qual fazem parte.

Embora o clima do poema seja tenso e desesperador - o fantasma sente que o seu encontro de culturas foi frustrado e causou inúmeros traumas psicológicos - a métrica não varia muito, permanecendo em torno de dez sílabas poéticas, com alguma variação nos pés poéticos. Talvez essa aparente harmonia métrica seja para, novamente, demonstrar a falta de liberdade do sujeito, pois mesmo frente a uma ordem harmônica e pacífica, há inúmeros conflitos de ordem psicológica e cultural sendo colocados, visto que, quando requisitado a mudar de lar para as missões, o padre teve de compreender a cultura de um outro, de modo a expropriá-la e incutir a sua. Há, igualmente, um movimento de abertura e fechamento sendo colocado em questão: enquanto de início o poeta descreve o aparecimento deste fantasma trazendo à tona lembranças dispersas em sua memória, no decorrer das estrofes, ele dá falas a esse personagem, deixando-o livre para discorrer sobre a sua experiência traumática na floresta tropical. Após esses dois momentos, há um novo movimento para o interior da recordação do poeta e o padre volta a falar. Todavia, sua última fala revela uma análise psicológica do próprio autor que lhe revela o fato de estar se despedindo de sua terra. Novamente, as melodias, de maneira polifônica, são ora orquestradas pelo padre, ora pelo poeta.

Tal mecanismo de abertura e fechamento dá um caráter cíclico ao poema e cria uma força de resistência perante uma visão única do sujeito pós-colonial. Se observarmos a figura do padre, compreendemos que esse representa aquele que, devido à força ideológica imperial, adaptou-se à imagem do subalterno colonial e usa dessa ideologia para destituir o 
caráter de insurgente de sua própria cultura. Porém, se examinarmos a figura do poeta, entendemos que Heaney usa o exemplo desse sujeito para se colocar como alguém que resiste à subjugação. Ao colocar em paralelo estas duas formas pelas quais o sujeito colonial é apreendido, o autor viabiliza a compreensão da constituição do subalterno como aquele que tem a experiência da:

desaparição, como algo além de silêncio e inexistência, uma aporia violenta entre sujeito e objetificação... entre patriarcalismo e imperialismo, constituição de sujeito e formação de objeto, a figura... desaparece, não em um nada primitivo, mas em um violento deslocamento [shuttling]. (SPIVAK, 1993, p. 102) $)^{92}$

Essa noção pode ser comprovada com as falas descritivas e angustiadas do clérigo no tocante ao lugar para onde ele foi designado. Na percepção do poeta, observamos que ele é aquele sujeito que detecta uma resistência ao seguir seus próprios passos, mas sem conferir um julgamento de valor pejorativo em relação ao "outro". No poema, observamos que Heaney pretende se desprender dessa configuração, ao dar voz ao padre, ou seja, àquele que foi um dos sujeitos dessa desaparição imperial.

O "deslocamento violento" sobre o qual Spivak argumenta em seu texto está relacionado a um processo contínuo e ininterrupto que se modifica de acordo com diferentes momentos históricos. Com isso, o poeta, ao colocar a mesma experiência em níveis diferentes:

traz dentro de si o passado - como cicatrizes de feridas humilhantes, como uma instigação a práticas diferentes, como visões potencialmente revistas do passado que tendem para um futuro pós-colonial, como experiências urgentemente reinterpretáveis e revivíveis, em que o nativo outrora silencioso, fala e age em território tomado do colonizador, como parte de um movimento geral de resistência. (SAID, 1999, p. 269)

\footnotetext{
92 Texto pioneiro no que diz respeito aos estudos subalternos em que Spivak analisa as possibilidades que o sujeito pós-colonial tem de desenvolver uma voz própria. Com uma base pós-estruturalista acoplada ao materialismo histórico e ao feminismo, a autora analisa as possibilidades de agência do subalterno, principalmente do ponto de vista econômico e social. Original: "disappearance' with something other than silence and nonexistence, a violent aporia between subject and object status (...) between patriarchy and imperialism, subject-constitution and object-formation, the figure... disappears, not into a pristine nothingness, but into a violent shuttling". (SPIVAK, 1993, p. 102)
} 
Portanto, é uma característica de resistência colocar a subjetividade dominada em diálogo com a outra que pretende escapar desse determinismo, especialmente porque cria novas compreensões sobre o presente que se livram do positivismo e se tornam simultâneas, sobrepostas e intertextuais - como a própria polifonia que sua arte poética compõe.

As primeiras cinco estrofes do poema denotam uma descrição subjetiva do poeta espaço e ações - no momento em que ele recebe a visita do fantasma. Seria significante nos perguntarmos o porquê ele aparece exatamente no instante em que esse está pronunciando as palavras: "renuncio" e, em tom servil, "pai”. Parece que há uma interligação, nesse momento, entre o servilismo subalterno do fiel com aquele que o padre encarna. Além do mais, as palavras retiradas da liturgia católica também colocam a religião como uma instituição dominadora e aprisionadora, tanto quanto o poder colonial. Nessa aura de obediência, uma vez que o colonizado deve renunciar à subjetividade de modo a aceitar as novas configurações sociais como um filho obedece ao pai, o padre surge pronto para presidir os rituais da missa. Sua aparência elevada, com roupas de belos cortes, o enquadra ainda mais na figura daquele sujeito delineado pelo imperialismo. É importante atentar ao fato de que, primeiramente, a Irlanda fora dominada por São Patrício, missionário responsável pela cristianização da ilha no sistema episcopal de governo e por empenhar artistas e religiosos na construção de uma civilização baseada no culto aos estudos e à tradição. Por essa razão, o poeta representa o padre como alguém dominado por uma roupagem de um "outro". Ao deixar as palavras de conversão para ouvir o que o padre tem a dizer, Heaney também ouve a voz de um passado com o qual ele deve estabelecer um continuum.

\footnotetext{
Blurred swimmings as I faced the sun, my back to the stone pillar and the iron cross ready to say the dream words I renounce

Blurred the oval prints of newly ordained faces, "Father" pronounced with a fawning relish, the sunlit tears of parents being blessed.

I saw a young priest, glossy as a blackbird as if he had stepped from his anointing a moment ago: his purple stole and cord or cincture tied loosely, his polished shoes unexpectedly secular beneath
} 
a pleated, lace-hemmed alb of linen cloth.

His name had lain undisturbed for years

like an old bicycle wheel in a ditch

ripped at last from under jungling briars.

(O. G., p. 249)

O poeta começa a ouvir os relatos desse padre que percorrera caminhos desconhecidos. Primeiramente, ele relata que não conseguiu passar dois anos na floresta tropical, pois a nudez física das mulheres e dos homens o aterrorizava. Novamente, o padre confere um juízo de valor perante os hábitos daqueles homens, sendo que a cultura deles não associava a questão sexual à nudez física. Em decorrência desse choque cultural, não consegue proferir as palavras das missas, fazendo com que a natureza de sua vocação seja questionada. Dito isso, o clérigo se volta ao poeta e compara sua idade à dele, como se os dois tivessem percorrido as mesmas estradas e tido as mesmas experiências traumáticas. Com essa comparação, entrevemos uma confluência de ideais que chegam a um ponto culminante: a diáspora. Embora essa esteja relacionada a grandes massas, podemos denominar tal comparação de diáspora pois ambos deixaram a Irlanda do Norte para seguir diferentes vocações. Portanto, nesse momento, os dois estão envolvidos em uma relação mais profunda e complexa da qual podem surgir resultados positivos - se houver troca de valores e ideais - ou negativos - se os confrontos forem mais abundantes que as trocas dependendo da compreensão literária dessa passagem.

\footnotetext{
wet and perished. My arms were open wide but I could not say the words. "The rain forest", he said you've never seen the like of it. I lasted

only a couple of years. Bare-breasted women and rat-ribbed men. Everything wasted. I rotted like a pear. I sweated masses...

His breath came short and shorter. "In long houses

I raised the chalice above headdress.

In hoc signo... On that abandoned

mission compound. My vocation is

a steam off drenched creepers".

I had broken off the renunciation

while he was speaking, to clear the way

for other pilgrims queuing to get started.

"I'm older now than you when you went away".

(O. G., p. 250)
} 
Enquanto o clérigo discorre sobre seus sentimentos de exilado, Heaney retém a imagem doméstica do religioso, configurando uma escrita contrapontística. Enquanto um deles entoa a melodia do exílio, o outro, ao fundo, rememora a de um passado mais distante: quando ele voltava para casa durante os verões e lhe era permitido comportamentos corriqueiros, como caminhar no vilarejo, andar de bicicleta e comer pão caseiro. Além do mais, o poeta também o critica por se alegrar apenas com essas trivialidades e não ultrapassar as barreiras do doméstico e do comum - "kitchen grottos". Nesse momento, há um embate entre essas duas melodias: se por um lado, a do padre tem um tom triste e autopiedoso, a do poeta quebra essa tonalidade depressiva com a questão de que ele próprio se fechou e não quis proporcionar uma troca de valores e de identidades com aqueles que conheceu. $O$ interlocutor do poeta se ofende com tal afirmação, o acusando de estar fugindo de seu exílio e retornando a casa pelas mesmas razões saudades de um clima conhecido e seguro.

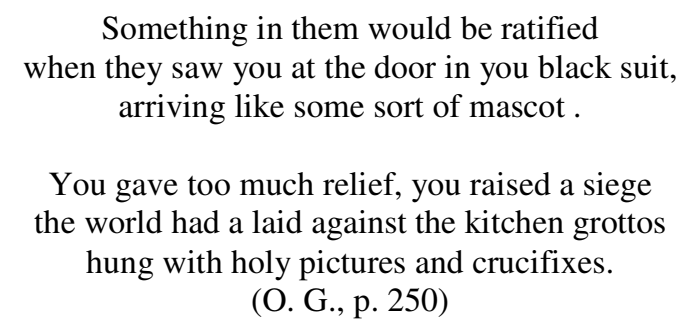

Novamente, a melodia volta a se fundir, pois o padre reafirma a semelhança entre os dos dois, frente à própria diferença posta por Heaney. Entretanto, quando o padre levanta a hipótese do poeta estar despedindo-se de sua terra de origem, o poeta se cala e começa a ponderar sobre a veracidade de tal descobrimento. O poema, então, finda com o poeta percorrendo o espaço onde o fantasma desaparece. Mais uma vez, a melodia entra em dissonância e Heaney compreende que ele próprio se assemelha ao padre ao retornar à Irlanda do Norte e passar por todo ritual da "Station Island". Mesmo assim, o fato primordial que o autor chama a atenção nessa parte de seu texto é como o exílio pode ser uma experiência expressiva, ao trazer diferentes conotações e criar identidades multifacetadas. Nesse caso, ele cria uma pequena composição em fuga, em que tanto poeta quanto padre são colocados, ora em igualdade, ora deslocados para posições diferentes, mas com um campo ainda em comum, o fato de serem irlandeses e terem saído de seu país. 
A noção de identidade atinge um escopo ainda maior nesse poema, porque o autor descobre que não é apenas aquele sujeito que aprende com as diferenças - que tem uma visão mais abrangente do mundo - mas que é, ao mesmo tempo, como o padre, um sujeito provinciano que volta para sua casa para reviver costumes e hábitos com os quais ele foi criado. Embora estando na Irlanda do Norte enquanto dialogam, esse lugar se torna metafórico e transcendental, pois Heaney, no final do poema, anda em círculos por onde ele passou, como se ele tivesse a necessidade de sentir as mesmas sensações angustiadas e sufocantes que o missionário sentira no meio das florestas tropicais. Não seria correto, porém, falar de um retorno às raízes, mas de uma troca de experiências nas quais o poeta precisa compreender as configurações de um exílio que seja puramente doloroso, e não cuja dor traz conhecimento e aprendizado. Heaney não fecha seu campo de visão, mas o abre em um caminho a uma identidade que se adapte à pluralidade do tempo presente e, como uma fuga musical, possua diferentes melodias em contraste.

Compreendemos que os quatro primeiros poemas, os quais constituem um primeiro movimento, representam a tomada de consciência do poeta de que ele nunca estará em lugar algum, embora haja lembranças e recordações atuando em sua memória. Com isso, ele demonstra os dilemas e questões que começaram a surgir na sua mente quando a importância do deslocamento foi considerada, e como seu despertar poético constitui uma polifonia composta de pequenos excertos de poetas irlandeses, ou até mesmo ingleses, que influem na sua psique. A projeção do eu se dá, portanto, na sua anulação e reconstituição fragmentada, e na reconstituição das presenças ausentes do "uncanny". Em outras palavras, ele compreende no estranho e estrangeiro, a sua própria subjetividade, quer seja na forma, quer seja nas intertextualidades, ou personagens vivos de sua infância. Portanto, trata-se de uma partida na qual o poeta recupera e revê os dilemas vividos na infância e no início de carreira.

Ademais um início de exílio proporcionado pelas perguntas do padre que fora mandado para fora de seu país é um prenúncio de seu próprio afastamento. Ao mesmo tempo em que ele não quer ser identificado com esse fantasma que o acusa de estar se despedindo da Irlanda, ele se identifica com sua ingenuidade e falta de percepção dos efeitos do poder imperial na cultura nacional. Dentro desse fluxo de personalidades literárias tomando conta do poeta, encontramos a história da nação sendo escrita e impressa 
no sujeito. Com isso, fragmentando-se em diversas pessoas, ele encontra as relações de poder perpetuadas pela experiência colonial, e ainda mais, coloca a sua própria experiência nesse fluxo de movimento. Ao fazer isso, o autor expurga e recoloca a sua própria vida em outro ritmo, aquele que mesmo desejando se afastar da terra de origem, se confunde com o a contrastante herança tradicional e moderna de sua sociedade.

Em suma, nessa primeira parte de "Station Island" Heaney consegue compreenderse a si próprio nos outros e reinscrever a herança subalterna de sua nação nas diversas metamorfoses subjetivas que assume. Ao "travestir" (SPIVAK, 1999, p. 7) ${ }^{93}$ sua métrica e subjetividade, o poeta, garante uma linha de força em que a diferenciação cultural torna-se uma alternativa à homogeneização global. Isso se dá por meio de irrupções subjetivas em que a subjetividade do autor assume o caráter sufocante daquele que se observa objetificado. Isso se dá principalmente porque o poeta sofre a violência epistêmica própria dos processos de identificação. Desta maneira, na continuação de nossa análise focaremos na culpa que surge quando o poeta se afasta de sua sociedade.

\footnotetext{
${ }^{93}$ Termo usado por Spivak para denominar uma leitura que se traveste no outro. (SPIVAK, 1999, p. 7)
} 


\title{
2. Os Efeitos Metonímicos do Exílio
}

\author{
"I have already come to the verge of \\ Departure. A month or so and \\ I shall be vacanting this familiar room. \\ Its fabric fits me like a glove \\ While leaving latitude for a free hand. \\ I begin to put on manners of the world, \\ Sensing the split light above \\ My head, where in silence I lie curled".
}

(MAHON, 1986, p. 283)

No capítulo anterior observamos como os deslocamentos subjetivos de Heaney reproduzem a violência das sociedades pós-coloniais, gerando, por meio da representação do subalterno, uma consciência subjetiva e histórica. Modulando sutilmente essa tonalidade, o poeta, no segundo movimento de "Station Island" (partes V, VI, VII e VIII) potencializa sua culpa através dos ritos performáticos de sua estação e nos apresenta figuras que reconstroem um afastamento geográfico de sua terra de origem. Enquanto no primeiro movimento os subalternos com os quais ele entra em contato são relacionados ao mundo infantil e familiar, no segundo, ele os desvia para os mestres da escola, passa pela primeira garota com quem tem sua iniciação sexual e chega às vitimas dos Troubles. Com isso, temos a "renúncia" da seção IV se metaforizando, uma vez que o arrependimento dos pecados no ato religioso, transmuta-se na decisão de trilhar seu rumo próprio e aceitar o exílio.

Ao fundir, em sua peregrinação onírica, as categorias da sexualidade, da culpa e da história, o poeta ensaia um movimento semelhante ao que Hayden White (2000) explicita sobre a interpretação dos sonhos de Sigmund Freud. Para o historiador, no momento em que Freud postula que os sonhos são a maneira pela qual o inconsciente lida com uma realidade repressiva e um desejo latente, através de uma linguagem simbólica e deslocada de seu contexto, o psicanalista está descrevendo, na realidade, o modo como a linguagem literal torna-se figurativa. ${ }^{94}$ Seria exatamente esse o nosso elo de ligação entre o primeiro e

\footnotetext{
${ }^{94}$ A aproximação entre psicanálise e literatura feita por White se dá na questão tropológica (um deslocamento de significados). Segundo o autor, "I believe what Freud has done in his reflections on the relations between
} 
segundo movimentos de "Station Island" visto que, por meio do sonho e da culpa, a literalidade, ou seja, o desejo da renúncia, transmuta-se na metáfora do exílio, gerando a culpa.

A partir desse posicionamento, encontramos o poeta em um processo de integração e diferenciação, pois, segundo Candido:

a integração é um conjunto de fatores que tendem a acentuar no indivíduo... a participação nos valores comuns de uma sociedade [enquanto a] diferenciação... é o conjunto dos que tendem a acentuar as peculiaridades, as diferenças existentes entre um e outro. (CANDIDO, 1976, p. 23$)^{95}$

Portanto, o poeta inicialmente se integra em sua comunidade via intertextualidade e métrica e, posteriormente, diferencia-se a partir do sonho e da culpa, ambos concretizados na representação metafórica do exílio. Ademais, é necessário reafirmar que uma das condições de possibilidade para isso é a métrica que, novamente, sofre mudanças significativas. Como Heaney afirma, a forma poética é, ao mesmo tempo, a âncora e o navio (HEANEY, 1998, p. 466), ou seja, mesmo produzindo uma fixidez centrípeta que o possibilita girar em torno de si mesmo, ela é um movimento centrífugo que lhe permite chegar a novas abstrações. Desta maneira, por meio da estabilidade de elementos poéticos, principalmente a rima, o poeta representa a instabilidade de sua subjetividade, delineada pelo remorso e autopunição. Com isso, seu exílio ganha respaldo social para representar a violência histórica e a própria violência artística de apreender fatos traumáticos - mesmo quando distante desses.

Na parte $\mathrm{V}$, de modo a demonstrar seu afastamento do grupo familiar, o poeta dramatiza novos encontros com os três antigos mestres da escola secundária onde estudou. Mesmo evocando lembranças dúbias e fragmentadas, Anahorish é um local de grande importância para o autor, visto que em alguns de seus poemas mais importantes ele retoma

the dream-content and its more basic dream-thoughts is to rediscover, or reinvent, the theory of tropes conventionally used by rhetoricians in his culture to characterize figurative language in general and to explicate the relation between literal and figurative meanings in poetic discourse specifically (p. 102). (WHITE, 2000, pp. $101-125$ )

${ }_{95}$ O objetivo de Antonio Candido na escrita desse ensaio é focalizar como os aspectos sociais envolvem a vida artística e literária. Para tanto, a sociologia não é vista como uma ciência auxiliar no trato com a literatura, mas como uma ferramenta que pode salientar alguns aspectos fundamentais da obra. Citando René Bady, ele conclui: "O poeta não é uma resultante, nem mesmo um simples foco refletor; possui o seu próprio espelho, a sua mônada individual e única. Tem o seu núcleo e o seu órgão, através do qual tudo passa e se transforma, porque ele combina e cria ao devolver à realidade" (p. 18). (CANDIDO, 1976, p. 23). 
a questão de como a instrução que recebera age em sua subjetividade. $O$ primeiro poema em homenagem ao "lugar de águas claras" - tradução do nome - está em Wintering Out (1972) em que Heaney descreve um movimento decrescente da luminosidade encontrada pela educação, até a escuridão das casas, sugerindo que a primeira, embora proporcionando conhecimento e erudição, é responsável por seu afastamento das camadas populares. Quando o autor retoma a temática em "Station Island", essa adquire uma nova configuração, principalmente porque os severos professores, que são igualmente representados em “The Ministry of Fear” (North, 1975), tornam-se pessoas mais próximas, chegando até a aconselhá-lo. Um dado diferencial seria o fato do poeta Patrick Kavanagh estar dentre esses homens.

$\mathrm{O}$ primeiro mestre (master) que surge no caminho possui traços animalescos e envelhecidos, pois Heaney descreve suas mãos como patas que remam contra o ar. Ele o chama de "Master Murphy" e, a partir da sonoridade jâmbica provinda desse nome, memórias involuntárias começam a surgir: a irritação com os alunos, os questionamentos sobre conceitos e o clima de opressão na sala de aula levam o poeta a enxergar o professor como um símbolo natural da ilha, visto que seus pés se assemelham a feijões expostos em uma jarra. Nesse sentido, há uma semelhança entre o mestre e o lugar descrito, porém, simultaneamente, há uma diferença, pois ele seria como um elemento artificial introduzido nessa paisagem: os feijões estão cortados, os seus ouvidos atentam para a sonoridade do lago e suas "patas" remam em direção desconhecida. Logo, há um contraste entre a vida civilizada e moral que esse homem ensina aos jovens alunos, e aquela quase primitiva e medieval que acontece em Lough Derg quando os peregrinos decidem enfrentar suas estações.

\footnotetext{
An old man's hands, like soft paws rowing forward, Groped for an warded off the air ahead Barney Murphy shuffled the concrete. Master Murphy. I heard the weakened voice bulling in sudden rage all over again and fell in behind, my eyes fixed on his heels like a man lifting swathes and a mower's heels His sockless feet were like the dried broad bean that split its stitches in the display jar high on a window in the old classroom, white as shy faces in the classroom door.
} (O. G., p. 251) 
O metro utilizado pelo poeta nessa parte relembra as longas seções de "The Ministry of Fear" (North, 1975), em que a infantil subjetividade lírica, através da intertextualidade com Patrick Kavanagh, William Shakespeare e Graham Greene, compreende que a lírica inglesa está tão presente na irlandesa, assim como o governo inglês em Ulster. Portanto, em qualquer lugar que ele estivesse, haveria um estranhamento constante por pertencer a um povo colonizado, cujas bases culturais e estéticas se encontram dispersas ao longo de uma relação conflituosa entre dominadores e dominados. Entretanto, nesse poema, o mestre da escola não citará Shakespeare, ou qualquer outro autor; ele irá apenas, modestamente, elogiar o seu antigo pupilo. Desta atitude, entrevemos alguém cujas conclusões são semelhantes às do poeta, mas que não consegue se desprender de seu determinismo social. As cinco longas estrofes de dezenove, onze, quinze, quinze e dois versos aproximam-se do tom descritivo da prosa, dissolvendo a métrica curta de poucos versos. Deste fato, compreendemos que o autor está se afastando ainda mais das tradições populares por não haver nenhum verso redondilho maior ou menor.

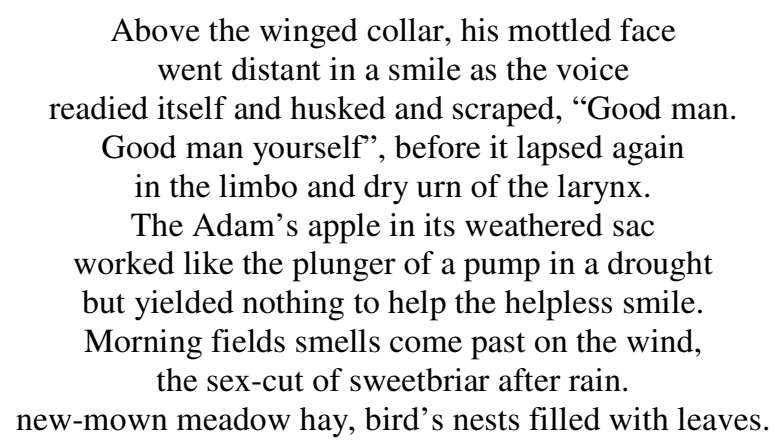

(O. G., p. 250)

Como observamos no trecho citado, no momento em que Murphy dirige a palavra a Heaney, há algo de doloroso e aterrorizante em sua voz, como se as aliterações plosivas que findam em fricativas mimetizassem o grande esforço da mente perfurando a secura de sua elocução. Apesar de simples, suas palavras denotam a coloração metafórica daquele que é silenciado por algo maior, talvez um sorriso sem esperanças, ou então uma memória que o cala, deixando apenas a abstração de um sentimento ou conceito dentro da forma poética, ou, o que na teoria formulada por Louis MacNeice, é denominada por "sistematização" de uma "significação". No que concerne à métrica, o poeta modernista irlandês, Louis 
MacNeice (MACNEICE, 1939, p. 134) ${ }^{96}$, atenta para o fato de que cada som deve ser pensado de acordo com o sentido que deseja expressar. Porém, ao contrário do deleite com o belo, o resultado dessa operação sempre será algo tenso e problemático, nunca tranqüilo e prazeroso. Nesse sentido podemos identificar Master Murphy como o "nativo informante" cuja voz é silenciada pela linguagem dominante. Como definimos na introdução, o nativo informante é o sujeito que, embora não representado nas narrativas históricas imperiais, é parte constitutiva desse processo.

O poeta, por meio da metrificação, inscreve a leitura de seu "ouvido" na passagem. No seu interesse em explorar as maneiras pelas quais o prefixo auto- da autobiografia tornase oui- (ouvido), Derrida afirma que, na construção do sujeito político, o crítico deva ter um ouvido perspicaz para perceber as diferenças (DERRIDA, 1982, pp. 50-1). Nossa compreensão sobre essa afirmação é que a métrica sistematizada e tensa seria o palco onde as diferenças são verbalizadas. Portanto, o entendimento do poeta sobre a sua subjetividade provém da absorção do silêncio do outro, e como esse o caracteriza. Se no passado ele conseguiu ouvir a voz da instrução desse homem, ela é, agora, anulada, remetendo o ouvinte à ausência. Portanto, o som da garganta seca do professor seria exatamente o ouvido que confere o caráter de individual ao poeta, pois sua identidade se faz a partir do julgamento feito sobre sua subjetividade no verso "good man, good man yourself".

\footnotetext{
"You'd have thought that Anahorish School was a purgatory enough for any man", I said, "You have done your station", Then a little trembling happened and his breath rushed the air softly as scythes in his lost meadows.

"Birch trees have overgrown Leitrim Moss, dairy heads are gazing where the school was and the school garden's loose black mould is grass". He was gone with that I was faced wrong way into more pilgrims absorbed in this exercise. As I stood among their whispers and bare feet the mists of the mourning I set out for Latin classes with him, face to face, refreshed me. Mensa, mensa, mensam sang on air like a busy sharp stone. (O. G., p. 250)
}

\footnotetext{
${ }^{96}$ Louis MacNiece tem uma visão particular sobre a métrica como sendo unidades de sentido que corroboram para uma problematização da experiência. De acordo com ele, "rhythm rhyme, and also on alliteration and texture and sound-value generally, I would say that my own preference is for poetry which is musical, but that the characteristics of this music are not superficial prettiness or smoothness, but $(a)$ system and $(b)$ significance. When I write poetry myself, I always consider the sound of each line conjointly with its adequacy as meaning”. (MACNEICE, 1939, p. 134)
} 
A partir dos dois excertos, inferimos que, ao fazer essa operação de identificação e diferenciação, a qual abre um espaço para a integração do outro em sua subjetividade, o autor vê a escola como um purgatório suficiente para a vida do professor. Segundo a etimologia, o termo "purgatório" denota, concomitantemente, "purificar" (do latim "purgatorium") e "agir" (devido à raiz "agere"), fato esse que revela o raio de ação desse mestre. Mesmo assumindo um "poder" que não lhe pertencia, o poeta admirava a musicalidade das suas aulas de latim, principalmente a da palavra "mesa" a qual se refere em latim como "mensam", significando as duas autoridades na Irlanda: o altar da igreja católica, e a távola redonda dos cavaleiros ingleses. Sendo assim, através das operações inconscientes do desejo de pertencer a esse outro que o oprime, Heaney associa o império ao desejo, mas enviesado: por meio das aulas de seu professor. Novamente, como no primeiro movimento, o "poder" colonial gera um "saber" em que a arte torna-se um espelho das "relações de poder".

Após essa última lição, Murphy segue em direção aos jardins da escola e retorna à imaginação de Heaney. Mal ele termina sua conversa com um, outro surge e lhe oferece conselhos a respeito de poesia e viagens - esferas que, para o trabalho de Heaney, guardam íntima correlação. Primeiramente, o professor afirma que o amor é a força propulsora do verso, e que sempre é possível aprender alguma coisa quando se dá caronas a estranhos na estrada. Na subjetividade exilada do artista, o diálogo - a conversa informal - é sempre uma forma de adicionar elementos temáticos à sua poesia, e o amor se correlaciona à questão de solidariedade e como essa proporciona um maior entendimento social. Embora o poeta dedique onze dos dezenove versos da estrofe a esse segundo mestre, sua importância é reduzida, pois mesmo marcando sua presença, ele não tem um caráter constitutivo na poesia de Heaney: não há um confronto de idéias entre os dois, nem um julgamento sobre a sua personalidade, apenas comentários parcos.

Sendo assim, as falas do professor parecem ditadas por clichês e saturadas de repetições - "rubbed quotation" - contudo, Heaney as segue, muito provavelmente por sua nulidade em uma sociedade marcada pelo "estado dual de coisas: o irlandês mal-humorado, espoliado, mas recusando desaparecer, e o colonialista farisaico, nobre e severo". 
(KINSELLA, 1995, p. 120$)^{97}$ De modo a fazer a passagem da neutralidade para um posicionamento cortante, Heaney encontra o terceiro protetor: Patrick Kavanagh. Embora o poeta não deixe claro seu nome, é provável que ele o seja por três fatores: Kavanagh também escreveu um longo poema intitulado "Lough Derg Pilgrim"; em "The Ministry of Fear" Heaney faz uso de uma linha do poema "Epic"; e o tom irônico com que ele se expressa. Tamanho é o grau de ironia com o qual ele se dirige ao poeta que Kavanagh primeiramente o acusa de perseguí-lo e depois satiriza sua posição de exilado ao refazer essa peregrinação - que ele também fizera. Com isso, temos o retrato de um poeta desprovido de idealismos e consciente de que, dentro desse "estado dual de coisas", era necessário "esvaziar sua mente das categorias manipuladas por colonialistas e anticolonialistas" (KIBERD, 2000, p. 599, 600) ${ }^{98}$, ou seja, enxergar além dos ensinamentos propostos pelo primeiro e segundo protetores.

Certamente seria esse o legado de Kavanagh absorvido por Heaney pois, para ele, o naturalismo nunca foi idealizado, mas concreto e confuso. Segundo o autor, Kavanagh construiu:

uma vida desnuda de 'folclore' e elementos pitorescos encontrados na expressão... ao expressar essa vida... Kavanagh forjou uma posição, não como uma consciência, para a grande maioria dos seus conterrâneos, cruzando devoções de uma sensibilidade católica rural com a característica non serviam de sua personalidade original, revigorando as energias inabitadas de uma subcultura com poder de fonte. (HEANEY, 1980, p. $116)^{99}$

\footnotetext{
${ }^{97}$ O poeta Thomas Kinsella faz uma análise da poesia do norte da Irlanda como sendo produto de duas tradições contrárias entre si. Original: "It is the dual state of things: the sullen Irish, dispossessed but refusing to disappear; and the self-righteous colonist, high and dry". (KINSELLA, 1995, p. 120)

${ }^{98}$ Declan Kiberd analisa o legado de Kavanagh como uma reação contra o bucolismo de Yeats. Para o crítico, ele foi o primeiro poeta a abordar o tema do subdesenvolvimento do Norte, ironizando sutilmente o idealismo reacionário do Celtic Revival. Original: Had empted his mind of the categories devised by colonialist and anticolonialist alike". (KIBERD, 2000, p. 599, 600)

${ }^{99}$ Heaney analisa alguns poemas de Kavanagh, compreendendo sua poesia como algo que observa os problemas presentes da Irlanda em sua relação com passado. Como ele afirma sobre "The Great Hunger: "the hunger for a culture for its own image and expression. It is a poem of its own place and time transporting the grieves of the past... into the distress of the present... committed to a larger... concept of love whose function he decreed was not to look back, but 'to look on"”. (p. 126). Original: "A life denuded of 'folk' and picturesque elements, found its expression. And in expressing that life... Kavanagh forged not so much a conscience as a consciousness for the great majority of his countrymen, crossing the pieties of a rural Catholic sensibility with the non serviam of his original personality, raising the inhabited energies of a subculture to the power of a cultural resource.”. (HEANEY, 1980, p. 116)
} 
Nesse sentido, muito da poesia de Heaney segue essa linha temática que ele próprio ressalta sobre o poeta. Ao incorporar alguns dos temas de Kavanagh, Heaney cria, novamente, uma intertextualidade poética. Porém, essa se pauta em algo comum aos dois, algo que foi reprimido (foreclosed) de suas subjetividades e que retorna a se integrar na materialidade do verso. Sendo assim, essa "tradição dupla", somada ao retrato do camponês destituído, fazem dessas duas heranças culturais fontes importantes de exploração.

Ao mesmo tempo em que Heaney cria a intertextualidade, essa não é colocada apenas em nível temático, mas também estético. Se por um lado o autor parece ser ironizado por Kavanagh, por outro, ele responde às contradições postas por sua poesia. No poema "Innocence" Kavanagh escreve:

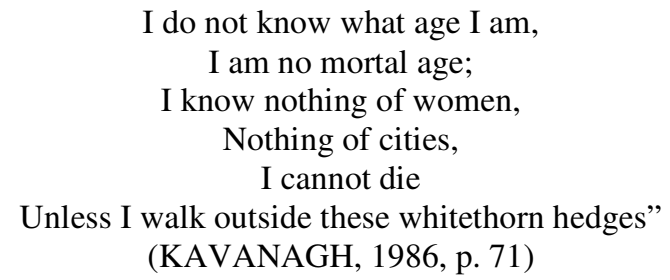

Esse pequeno poema em forma de negação expande seus pés redondilhos até o verso eneassílabo jâmbico, sugerindo, sarcasticamente, que o abandono das tradições folclóricas permitirá à subjetividade inexperiente o encontro consigo mesmo. Compreendemos também o grau de dependência dessa passagem, visto que o delinear da personalidade depende do desconhecido e mais poderoso culturalmente. Assim, a subjetividade pueril de Heaney se encanta com a cultura erudita na voz do Mestre Murphy, enquanto a criança do poema deseja cruzar as fronteiras de seu espaço geográfico. Entretanto, esse "outro" que o poeta realmente deseja encontrar é aquele que o subjuga e silencia. Sendo assim, Heaney, através de sua voz culpada (como a de Kavanagh) precisa da ironia e das acusações de Kavanagh para expurgar seus pecados. Porém, ao invés de purgar aquilo que o atormenta, o encontro o atordoa ainda mais, fazendo-o retornar ao caminho de Lough Derg para se purificar.

Desta maneira, Heaney reincorpora a versão de um Kavanagh sarcástico que não compreende a razão pela qual o poeta está, igualmente, fazendo essa peregrinação, e ainda o questiona se os próximos lugares que ele percorreria seria Dordogne - a cidade onde ele nasceu - ou Iceland, país cujo nome possui algo uncanny, pois é homófono à Irlanda. A 
partir desse trecho vemos que Heaney não está certo se essa estação produzirá algo positivo, visto que os fantasmas de sua juventude, na grande maioria, questionam-no, ou por haver retornado, ou por haver abraçado a vida de exilado. Logo, isso demonstra a própria situação inquietante em que o poeta se encontra: estar em uma peregrinação religiosa, rememorando sua juventude, e acima de tudo, sendo cobrado pelas interpretações que ele tem dos autores e de pessoas que o marcaram. Assim, se por um lado, o diálogo com os outros autores produz uma intertextualidade antropofágica em que o desejo do outro é tão grande que suas palavras são reproduzidas quase literalmente, por outro lado, o contato com as pessoas mais simples faz com que a figura do subalterno retorne, fazendo com que o autor recorde suas origens.

Usamos o termo intertextualidade antropofágica, pois, se por um lado a intertextualidade estaria relacionada "ao sistema de trocas, onde a questão da propriedade e da originalidade se relativizam", a antropofagia seria "uma devoração crítica... [em que há] uma seleção como nos processos da intertextualidade" (PERRONE-MOISÉS, 1990, p. 94) que convida o leitor a compreender, distanciadamente, como a tradição do passado é inserida em um novo momento histórico. (PERRONE-MOISÉS 1990, pp. 94-6) ${ }^{100}$. Desta maneira, conseguimos vislumbrar como o autor consegue, partindo da estética, compreender a si mesmo como um construto de diferentes personalidades literárias e subalternas. Como conseqüência, sua subjetividade é, ao mesmo tempo, moldada por uma diversidade de "personas" e pelo contexto histórico do qual faz parte, pois essas não deixam de ser figuras pertencentes ao seu universo.

\footnotetext{
We'll go someday to my uncle's farm at Toome" -

Another master spoke, "for what is the great

Moving power and spring of verse? Feeling, and in particular, love. When I went last year I drank three cups of water from the well. It was very cold. It strung me in the ears. You should have met him - "Coming in as usual with the rubbed quotation and his cocked bird's eye dabbling for detail. When you're on the road give lifts to people, you'll always learn something. There he went, in his belted gabardine, and after him, a third foster, slack-shouldered and clear-eyed: "Sure I might have known once I had made the pad, you'd be after me
}

\footnotetext{
100 Apoiamos nossa argumentação na explicação sobre os termos teóricos elaborada pela crítica Leyla Perrone-Moisés. (PERRONE-MOISÉS 1990, pp. 94-6)
} 
sooner or later. Forty-two years on

and you've got no father! But after that again,

where else would you go? Iceland, maybe? Maybe the Dordogne?

(O. G., p. 250)

Os últimos dois versos configuram a despedida de Kavanagh, mas ao invés de cessar com o sarcasmo, esse se torna ainda mais cáustico: "In my own day/ the odd one came here on the hunt of women", aludindo a uma possível comparação entre a culpa social e aquela provinda do ato sexual. Essa aproximação provém do fato das quatro últimas estrofes da passagem tocarem no tema, respectivamente, de exílio e sexualidade. Portanto, Kavanagh faz o autor rejeitar romantismos e idealismos em relação à sua terra de origem e à mulher, confirmando uma crítica à dominação cultural e econômica da ilha. Isso é identificado com a posição do autor perante a busca da identidade irlandesa na década de 1940:

enquanto uns buscavam encontrar no bucolismo rural a sua inspiração poética, Kavanagh chamava a atenção para a falta de condições e oportunidades que essa classe social possuía, fato que fica evidente em "The Great Hunger. (CAIRNS; RICHARDS, 1988, p. 136) ${ }^{101}$

Ao despedir-se de modo irreverente, Kavanagh deixa marcas profundas no autor, pois o faz refletir implicitamente sobre a religião, a sexualidade e a terra de uma maneira histórica e crítica. Como já havia feito anteriormente em "Act of Union” (Stations, 1975), Heaney versa sobre a questão da sexualidade segundo a metáfora do estupro físico da mulher, e a colonização da Irlanda pelo império britânico. Desta maneira, na parte VI do poema, o poeta aborda essa temática à luz da sua experiência pessoal, principalmente porque, quando o terceiro mestre profere a seguinte afirmação: "Forty-two years on/ and you've got no father", somada ao comentário, "In my own day,/ the odd one came here on the hunt for women", ele está, na verdade, sugerindo que a ligação de Heaney com a mãe (Irlanda) é tão grande, que ainda existe um complexo de Édipo mal resolvido. Tais

\footnotetext{
${ }^{101}$ Writing Ireland de D. Cairns e S. Richards é o livro pioneiro nos estudos Pós Coloniais irlandeses. Apesar de haver um foco maior nos séculos XIX e começo do XX, os autores do estudo compreendem as relações culturais e políticas da Irlanda a partir de uma visão estritamente colonial, uma vez que essa ocorre principalmente por meio da língua, que se realiza materialmente no discurso: "a linguistic unity or group of statements which constitutes and delimits a particular area of concern, governed by its own rules of formation with its own modes of distinguishing truth from reality" (p. 1). (CAIRNS; RICHARDS, 1988, p. 136).
} 
questionamentos fazem parte da dramatização do amadurecimento da voz poética, que busca, intertextualmente ou antropofagicamente, encontrar a sua definição como artista.

\section{O PRAZER E CULPA}

Na parte VI do poema a voz literária de Heaney apropria-se de versos provindos da Ode 3.21 de Horácio e de linhas do "Segundo Canto" do Inferno de Dante de modo a representar o seu primeiro encontro amoroso; a moça com a qual ele perde a virgindade também está presente no poema. Nas duas alusões explícitas, o autor cria uma intertextualidade com temas relacionados ao deleite corporal, sendo que a ode é sobre os prazeres do vinho, e os versos do Inferno tratam das almas que sucumbiram à luxúria. Embora a sensualidade marque o tom dessa sexta parte, acreditamos que a política também esteja envolvida, principalmente porque enquanto Horácio lutou como soldado na Batalha de Filipos, Dante foi exilado devido as suas alianças partidárias em oposição ao governo. Se por um lado ser banido de seu lugar de origem gera indignação no poeta italiano, segundo Giuseppe Misotta, essa atitude expande sua visão acerca de um lar fixo, pois "os romanos aprendem a superar a 'nostalgia ilusória' de um perfeito retorno ao ponto de origem” (MISOTTA, 1991, p. 4). Essa superação se dá, concomitantemente, na reflexão histórica, visto que Dante viveu em uma Itália dividida entre o poder Imperial e o clerical, instâncias cujas influências foram marcantes na formação da Irlanda contemporânea.

Ao deglutir a voz poética e privada de poetas de outras gerações e espaços, Heaney não transcende a uma temporalidade metafísica em que os "espíritos" agem como se não tivessem mais conexões com sua vida terrena, mas traça paralelos entre suas diferentes questões históricas de modo a compreender seu próprio espaço e tempo e conferir um sentido de identidade à sua constituição artística. Para Erich Auerbach, uma das características unificadoras de A Divina Comédia é o fato de:

Dante transfer[ir]... a historicidade terrena para o seu além; os seus mortos estão privados do presente terreno e das suas mudanças, mas a lembrança e a intensa participação no mesmo os arrebatam de tal forma que a paisagem do além se torna carregada... mas a existência terrena permanece sempre manifesta. (AUERBACH, 2004, p. 168) 
Ao notarmos que todas as "personas" com as quais Heaney dialoga estão "mortas", ou falam como "espectros" de sua memória, essas se comportam de acordo com suas vidas terrenas, e não como seres destituídos das lembranças dos lugares onde nasceram e viveram. Nesse sentido, esses indivíduos tornam-se receptáculos de lugares, de histórias e estórias, com as quais o poeta constitui sua subjetividade de facetas múltiplas e transitórias. Enquanto o poeta cria vozes para as pessoas que já morreram, ele também cria uma voz coletiva para si mesmo.

Para Lloyd, há um impulso conservador na tentativa de Heaney de estruturar coletivamente sua subjetividade, pois sua poesia encobre a ideologia do trabalho e da exploração material, ao apenas dar vazão à importância da escrita:

Do lado do autor, a escrita é imediatamente vista como uma identidade constitutiva e expressiva liberada da unidade incoerente de seu solo. Esse ato de produção subjetiva fornece ao autor sua representatividade como humano, apesar da especialização de seu trabalho. Para o leitor o ato de ler parece um ato libertador. Ler, criticar, é exercitar o direito de julgamento privado e, portanto, de desenvolver melhor sua individualidade (LLOYD, 1993, p. $36)^{102}$

Ao contrário de entrarmos na discussão sobre como a cultura reproduz as incoerências não somente históricas, mas também locais e sociais, acreditamos que tal feito não possa ser descartado por completo, principalmente porque em uma situação de guerra civil decorrente de uma infinda dominação geográfica "a terra tinha sido e estava sendo dominada por um poder externo, fosse ele liberal, monárquico ou revolucionário". (SAID, 1999, p. 272) Sendo assim, a polifonia subalterna criada pelo poeta é mais que um simples impulso mercadológico, mas uma criação que reivindica, reabita e renomeia o lugar que é invadido ilicitamente. Porém essa, ao invés de reproduzir o status quo da metrópole, consegue, nos termos de Dipesh Chakrabarty, emergir como “arquivos subalternos", pois:

as relações subordinadas ao passado de "passados subalternos"... são marginalizados não por intenções conscientes, mas porque representam

\footnotetext{
${ }^{102}$ Parte da conclusão do crítico acerca da obra de Heaney. No tocante à poesia do autor, Lloyd é um de seus críticos mais obstinados. Original: On the side of the writer, writing is envisaged as at once constitutive and expressive of an identity liberated from the incoherent unity of its ground. That act of self-production gives the writer his representativeness as human despite the specialization of his labour. For the reader, the act of reading appears also as a liberating act. To read, to criticize, is to exercise the right of private judgment and thereby to develop one's best self. (LLOYD, 1993, p. 36).
} 
momentos ou pontos em que o arquivo que a mente do historiador desenvolve um grau de intratabilidade em respeito aos objetivos da história profissional. Em outras palavras, esses são passados que resistem à historicização. (CHAKRABARTY, 2000, p. 191) ${ }^{103}$

Exatamente por essa razão, o poema torna-se tão ambíguo e fragmentado quanto a Irlanda do Norte na época em que foi escrito. A nosso ver, esse é fruto das tensões identitárias que surgem da re-escritura das histórias subalternas. Essas, por sua vez, são aquelas que irrompem o fluxo da história, e mesmo em um espaço que parece ahistórico e atemporal - como o do poema - são criadas novas possibilidades de arquivos e versões. Conseqüentemente, embora possa haver um impulso libertário na escrita (até mercadológico como Lloyd ressalta), esse é sempre abafado e questionado pelos "outros" (o subalterno, o nativo informante, etc.) que foram deixados de lado na escritura da história oficial.

$\mathrm{Na}$ primeira estrofe, portanto, observamos o poeta recordando cenas da infância e adolescência, onde ele conhece a garota com a qual ele tem o seu primeiro contato íntimo. Inflado pela culpa de cunho religioso, e pela confusão de uma identidade ainda em formação, o autor sofre uma insolação enquanto brinca de casinha com a mulher amada, cujos contornos físicos são de cunho natural - "giestas", "raposas" e "avencas" a esculpiram. Após a descrição, ele faz uma digressão sobre a quietude do lugar e a imobilidade dos objetos que, através da confissão de segredos mais íntimos - até de Midas - conversam com ele. Já de princípio tem-se uma questão sendo posta: será que essa presença feminina do poema se refere a uma pessoa concreta, ou então a um feminino que se assemelha às próprias lendas da Irlanda como atraente jovem? Fica, então, claro que mesmo as questões de ordem pessoal rompem a cápsula do privado e atingem problemáticas sociais e culturais mais profundas, obrigando o leitor a, não apenas compreender seu sentido em nível doméstico, mas também em nível coletivo e histórico.

\footnotetext{
${ }^{103}$ Chakrabarty pretende, através de Provincializing Europe, "explor[es] how [Western] thought—which is now everybody's heritage and which affect us all — may be renewed from and for the margins". Original: Let me call these subordinated relations to the past "subaltern" pasts. They are marginalized not because of any conscious intentions but because they represent moments or points at which the archive that the historian mines develops a degree of intractability with respect to the aims of professional history. In other words, these are pasts that resist historicization. (CHAKRABARTY, D., 2000, p. 191)
} 
Where did she arrive from? (A)

Like a wish wished (B)

And gone, her I chose at "secrets" (C)

And whispered to. When we were playing houses. (D)

I was sunstruck at the basilica door - (E)

A stillness far away, a space, a dish. (B)

A blackened tin and knocked over stool - (G)

Like a tramped Neolithic floor (E)

Uncovered among dunes where the bent grass (I)

Whispers on like reeds about Midas's (I)

Secrets, secrets, I shut my ears to the bell. (J)

Head hugged. Eyes shut. Leaf ears. Don't tell. (J)

Don't tell (J)

(O. G., p. 251)

Outro fator que nos chama atenção na leitura da estrofe acima são as rimas paralelas que, embora irregulares, são raras na musicalidade poética de Heaney. Essa estrutura repetitiva é também observada de forma regular na A Divina Comédia - tercetos que seguem o esquema $\mathrm{ABA}$ BCB CDC... YZY Z - porém, no decorrer dos versos, essa composição se desvanece e o poeta passa a ressoar a mesma unidade sonora até o final. Esse paralelismo formal com Dante comprova que o poeta pretende colocar sua presença na tradição literária, contudo, apesar de sua exímia habilidade estética, ele prefere diferir dos pressupostos estabelecidos pelo escritor italiano, muito provavelmente porque pretenda continuar com sua experimentação métrica - aquela que o faz soar bastante como "Heaneyspeak" (HOMEM, 1999, p. 29) ${ }^{104}$ - e, certamente porque pretende uma forma que, por seus "deslocamento modernos e tradicionais" e "hibridismo", penetre nas questões históricas e políticas irlandesas levantadas pelos encontros subjetivos do poema. Nesse sentido Heaney, ao trazer de volta a musicalidade do verso de Dante, historiciza sua obra, conferindo valor não somente ao poeta italiano, mas à sua própria. Como o crítico italiano Giuseppe Castorina aponta:

O senso da sílaba, da rima, do ritmo que mergulha no primitivo e une passado e presente, e é aquilo que mais o [Heaney] fascina em Dante, que é considerado por Heaney "o maior poeta estrangeiro do segundo milênio" (CASTORINA, 2001) $)^{105}$

\footnotetext{
${ }^{104}$ Termo cunhado de Rui Carvalho Homem para designar o ritmo estabelecido por Heaney, que por ser demarcado por assonâncias e aliterações, constituem seu estilo. (HOMEM, 1999, p. 29)

${ }^{105}$ Para Giuseppe Castorina, Heaney retira Dante do panteão e o traz de volta para o palato, ou seja, o poeta vê Dante como um constante centro de renovação e criação artística. Original: "Il senso della sillaba, della rima, del ritimo che afonda nel primitivo e unisce passato e presente, è cio che lo affascina maggioriamente in Dante, che Heaney considera "il più grande poeta straniero del secondo millennio". (CASTORINA, 2001).
} 
Seria relevante que essa reação só tem início após a provocação perspicaz de Kavanagh. De acordo com Thimothy Kearney:

a realização dos poetas do norte está na sensibilidade de sua resposta perante a crise pós-moderna da alienação. Eles insistem em compreenderem suas experiências em termos comunais... a experiência é de um conflito irresoluto $\left(\right.$ KEARNEY, 2000, p. 67) ${ }^{106}$

Justamente em razão dessa característica, na segunda estrofe, vemos o poeta retornando ao tempo presente da sua estação, porém a visão dos peregrinos o recoloca na digressão anterior. É como se a recordação dos fatos também dependesse daqueles que estão com ele - seja em estado físico ou espectral. Nesse momento, ele retoma experiências extremamente prosaicas, em que, no fim do verão, os trabalhadores rurais rendem-se ao vinho e às canções poéticas. Contudo, o verso apoderado da Ode 3.21 de Horácio ${ }^{107}$, que trata dos benefícios do vinho - dar disposição, restaurar mentes e despertar a coragem traz uma temporária paz, como uma pausa, pois na continuação dos versos, a culpa e inibição tomam conta da subjetividade ainda virginal do poeta.

A questão do prazer e tormento está intimamente ligada à apropriação de Horácio. Se por um lado ele figura como um imponente poeta, autor de odes cujas idéias remontam à filosofia "epicurista", em que era valorizada a felicidade provinda da tranqüilidade, por outro, o poema sente um estranhamento perante essas idéias, principalmente porque o eu lírico no final da estrofe, está confuso e desnorteado. Nesse sentido, o poeta aprende e desaprende com o exemplo de Horácio; para ele o poeta deve saber "misturar o útil ao

\footnotetext{
106 Heaney luta contra a crise contemporânea da alienação na sua identificação com as margens de sua comunidade, e com das lealdades divididas: como ele define, a pergunta que os poetas norte-irlandeses mais se perguntam é: "Can I belong to any community at all"? ao invés de " to which community can I best belong?... the real identity crises is... communal". (p. 64). Original: The achievement of the Northern poets lies in the sensitivity of their response to the Post-Modern crisis of alienation. They have insisted on realizing their experience in communal terms... that experience is one of unresolved conflict. (KEARNEY, 2000, p. 67)

107 "O Nata Mecum": "Born with me in the consulship of Manlius,/ whether you bring complaints or jollity/ or brawls and lunatic loves,/ or easy sleep, O holy wine-jar,// under whatever name you preserve the choice Massic,/ come down, you who deserve to be moved/ on a festal day. Corvinus is ordering me/ to bring out mellower wines. // Though steeped in Socratic dialogues,/ he will not be so austere as to neglect you/ Even old Cato's virtue, so they say,/ was warmed by unwatered wine. // You put natures at other times unbending/ on a gentle rack; with your cheerful god Lyaeus/ you reveal the cares of the wise/ and their secret counsels; // you give hope back to anxious minds/ and put horns on the poor man. After you// he does not tremble at the angry crowns / of kings or soldiers' swords// Bacchus, and Venus, if she comes in joy,/ the Graces slow to untie the knot,/ and the living lamps will prolong you/ while Phoebus returning puts the stars to flight". (HORACE, 2000, p. 98)
} 
agradável, [para] deleita[r], e ao mesmo tempo ensina[r] o leitor" (HORÁCIO, 1984, p. $107)^{108}$, mas a nosso ver, para Heaney a arte não ensina, mas forma historicamente o indivíduo - voltando ao conceito de Candido - visto que a literatura serve como ferramenta de reflexão no seu caráter coletivo e histórico. Nesse sentido, o prazer que o vinho e a poesia trazem é tão efêmero, que ele deve ouvir os sons dos hinos à virgem Maria, acordar e enfrentar mais um dia. Logicamente, nessa parte, A Divina Comédia passa a exercer maior controle sobre a subjetividade poética, deixando mais clara a sua culpa e frustração.

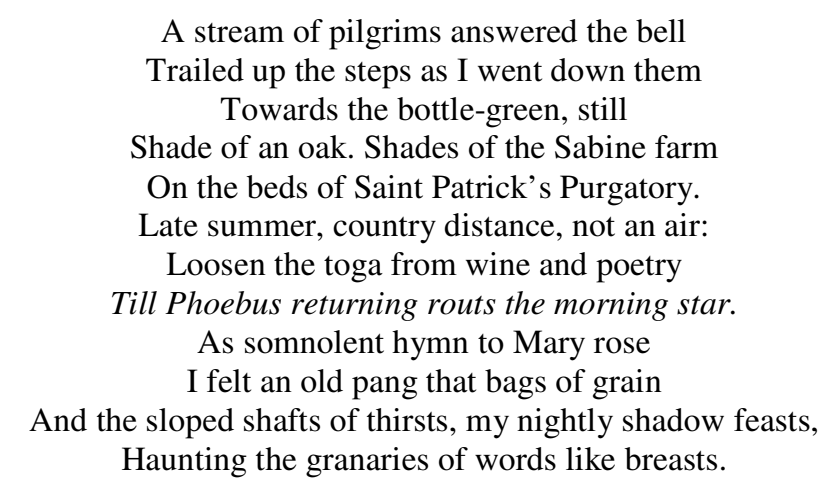

$\mathrm{Na}$ última estrofe o poeta se rende completamente ao encontro sexual e descreve a amada, novamente, com características pertinentes à sua paisagem local. Se por um lado há prazer nessa parte do poema devido à carga polissêmica investida em suas linhas através do caráter mais imediato do descobrimento sexual juvenil, por outro, há algo de doloroso uma vez que o poeta cria uma intertextualidade consigo através do poema "Act of Union" (North, 1975). Nesse poema a Irlanda é representada como uma dama forçada a dar a luz a um filho fruto do estupro colonial. Dessa forma, concomitantemente, há quatro forças atuando no interior da terceira estrofe: a antropofagia dantesca com o encontro final entre o poeta e sua Beatriz, o prazer proporcionado pela carga filosófica do carpe diem investida por Horácio, o conhecimento da terra através da poesia, e a culpa pelo ato sexual espelhar o estupro colonial. O que é observado exatamente na metade do poema é uma multiplicação de vozes a um nível extremo, em que não existe apenas uma melodia contrapontística de fundo, mas uma multiplicidade de vozes atuando no interior do poema, desafinando a composição e criando um efeito próximo da esquizofrenia, pois toda a composição é ${ }_{108}$ Tratado do poeta Romano em que ele, de forma didática, fornece conselhos e preceitos para a escrita
poética. Faz parte de sua epístola aos Pisões. (HORÁCIO, 1984, p. 107) 
reorganizada a partir de ópticas diferentes e visões de histórias que culminam no mundo contemporâneo - principalmente no mundo irlandês.

\footnotetext{
As if I knelt for years at a keyhole

Mad for it, and all that ever opened

Was the breathed-on grille of a confessional

Until that night I saw her honey-skinned

Shoulder-blades and the wetland s of her back

Through the wide key-hole of her keyhole dress

As window facing the deep south of luck

Opened and I inhaled the land of kindness.

As little flowers that were all bowed and shut

By the night chills raise on their stems and open

As soon as they have felt the touch of sunlight,

So I retrieved in my own willing powers

And my heart flushed, like somebody set free.

Translated, given, under the oak tree.
}

Primeiramente, como observado nos versos acima, a metamorfose dantesca se dá no encontro com o símbolo do feminino. No caso de A Divina Comédia, Beatriz é o antigo amor do poeta que, enviada por Deus faz com que ele se arrependa de seus pecados e seja conduzido ao Paraíso. (ALIGHIERI, 1996, pp. 43-7) ${ }^{109}$ Em contrapartida, a musa de Heaney é a mesma Irlanda violentada de "Act of Union" que, recordada pelos hinos à Virgem Maria, traz prazer através do encontro doloroso, ou seja, é como se o conhecimento de suas paisagens geográficas e da sua significância através dos tempos o libertasse. Entretanto, essa mesma consciência cultural o torna culpado visto que, mesmo tendo conhecimento sobre tais incoerências históricas, o autor tem somente apenas a "pena" como “arma”. Portanto, a apropriação de Dante não é apenas um recurso estilístico para demonstrar certa dose de erudição, mas um importante fator de "tradução cultural": apropriar-se da tradição italiana proporciona uma re-configuração de eixos históricos entre Irlanda e demais produções literárias tidas como canônicas. Seguramente, a sua metamorfose em Sweeney, Carleton, o Missionário, os Mestres e Kavanagh é exatamente

\footnotetext{
${ }^{109}$ Beatrice, true praise of God, why do (103)/you not help him who loved you so, who because of you came forth from the common herd?// Do you not hear the anguish of his weeping, do/ you not see the death that attacks him there, by the torrent where the sea has no boast? -... And I have come to you as she willed: from (118)/ before that beast I have taken you, that deprived you of the short path up the mountain.// Therefore what is it? why, why do you stand/ still? why do you nurse such cowardice in your heart? why do you not have boldness and freedom,...// As little flowers, bowed and closed in the chill of (127)/ night, when the sun whitens them straighten up all open on their stems: // so did I become with my tired strength, and so (130)/ much good boldness ran to my heart, that I began like a person freed. (ALIGHIERI, 1996, pp. 43-7)
} 
aquilo que o possibilita incorporar o cenário nacional como esse feminino repartido, disperso e congregado por diferentes representações culturais.

O contraste entre Dante e Heaney, mais do que a semelhança, é de suma importância, pois demonstra que enquanto o irlandês não encontra placidez em visões religiosas ou culturais, o italiano consegue conferir um tom de esperança e purificação a sua peregrinação através da elevação da humanidade:

experiência imediata da vida... que sobrepuja todas as outras... dentro [da] participação imediata e admirada de ser humano, a indestrutibilidade do ser humano total histórico e individual, baseada na ordem divina, dirige-se contra a ordem divina; põe a mesma a seu serviço e a obscurece; a figura do humano coloca-se à frente da figura de Deus. (AUERBACH, 2004, p. 175)

Nesse sentido, ao passo que Dante demonstra legitimar heroicamente a expressão humanística e histórica como resistência ao sistema autoritário da baixa Idade Média, Heaney exprime uma visão fragmentada do anti-herói desprovido de uma experiência única, mas disperso entre cadeias de personalidades múltiplas. Portanto, a óptica universalista do homem rumo ao Humanismo Renascentista, em que havia um senso de unificação e crença no progresso, não consegue mais respaldo no mundo pós-moderno, visto que este:

deve ser observado como uma imitação das práticas sociais, econômicas, e políticas na sociedade... porque representa diferentes facetas dessas práticas, aparece também em diferentes disfarces. A super-imposição de diferentes mundos através dos quais um 'outro' incomunicativo prevalece no espaço da coexistência, tem uma relação 'uncanny' (de estranhamento) com a crescente 'guetização', falta de poder e isolamento da pobreza e populações minoritárias. (HARVEY, APUD SCHWARTZ; RAY, 2000, p. 93) ${ }^{110}$

Como a compreensão unificadora da experiência não é mais compreendida no tempo presente, a questão introspectiva faz com que o poeta, nas próximas duas seções, lide com o tema político dos Troubles de 1969. Essa separação entre o poeta e Dante se dá

\footnotetext{
${ }^{110}$ Original: Postmodernism... ought to be looked at as mimetic of social, economic, and political practices in society. But since it is mimetic of different facets of those practices it appears in very different guises. The superimposition of different worlds... between which an uncommunicative "otherness" prevails in the space of coexistence, bears an uncanny relationship to the increasing ghettoization, disempowerment, and isolation of poverty and minority populations in the inner cities of both Britain and the United States. (HARVEY, APUD SCHWARTZ; RAY, 2000, p. 93)
} 
principalmente porque enquanto Beatriz fala ao poeta como porta-voz de Deus ${ }^{111}$, ou seja, de um masculino que a silencia novamente, a Outra Beatriz de Heaney se cala, apenas revelando a fenda de seu vestido, provavelmente como alegoria de uma paisagem deflorada por histórias de sofrimento e privação. Pelo fato de não conferir a sua voz à Irlanda, a Beatriz do poeta não é uma recompensa divina pela perda de um amor terreno, o que configuraria uma "plenitude psicoterapêutica", nas palavras de Spivak, mas uma instância altamente acusatória, pois sua poesia será uma reprodução desse cenário. Segundo o poeta: "vejo as peculiaridades religiosas da Irlanda como vogais e a consciência literária nutrida por consoantes inglesas", (HEANEY APUD KEARNEY, 1999, p. 110) ${ }^{112}$ portanto, essa cópula sonora faz também com que o poeta seja um agente dessa mesma exploração. Ao continuar, ele afirma:

há um numen territorial nativo, uma tutela de toda ilha de chamá-la de Mãe Irlanda..., o que quer que seja, e sua soberania foi temporariamente usurpada, ou infringida, por um novo culto masculino cujos pais fundadores foram Cromwell... e cuja divindade está encarnada em um rei... O que temos é o final de uma luta entre devoção territorial e poder imperial. (HEANEY, 1980, p. 57) ${ }^{113}$

Esse "final de luta" é colocado em questão na última estrofe, pois o $e u$ poético confere novos significados à relação entre mulher, terra e tradição literária. Como conclusão, temos uma releitura da "virtude ativa" de William Butler Yeats. Se para Yeats a forma poética era uma máscara: "distinta da passiva aceitação de um código", em que a subjetividade, de modo a responder aos apelos do sujeito empírico, transformava "a

\footnotetext{
${ }^{111}$ De acordo com Gayatri Spivak a fala de Beatriz é o resultado da apropriação do phallus masculino travestido na forma de coração de Dante. Ao devorar esse órgão do poeta em La Vita Nuova a mulher é incorporada a sua identidade e, concomitantemente, a de Deus, por ser descrita inicialmente como a corporificação do amor. Sendo assim, Beatriz é o sujeito objetificado pela qual o poeta alcança a plenitude psicoterapêutica. (SPIVAK, 1988, p. 19)

112 Richard Kearney defende que os poemas de Heaney não pertencem a pontos geográficos fixos, mas que tratam da passagem e deslocamento de um lugar para o outro. Original: "I think of the personal and Irish pieties as vowels, and the literary awareness nourished on English consonants.' The very words of Heaney's poems bear witness to this aesthetic of dual residence, to a poetic scruple of tireless migration". (KEARNEY, 1988, p. 110)

113 Original: "There is an indigenous territorial numen, a tutelary of the whole island, call her Mother Ireland,... whatever; and her sovereignty has been temporarily usurped or infringed by a new male cult whose founding fathers were Cromwell... and whose godhead is incarnate in a Rex... What we have is the tail end of a struggle in province between territorial piety and imperial power". (HEANEY, 1980, p. 57)
} 
identidade negativa em positiva... multiplicidade do ser". (HAMBURGER, 1969, 74-5) ${ }^{114}$ Heaney representa a mesma multiplicidade e individualidade. Porém, ambas entram em confronto: à medida que Heaney faz parte e assume a voz dessa multidão de pessoas, ele é, repetidas vezes, acusado e escarnecido por ela. Sendo assim, a positividade é perdida e o que temos é um anti-herói, ao mesmo tempo encantado com o prazer erótico, mas culpado por ser um dos responsáveis pela "terrível beleza que nasce" ("Easter 1916”, W. B.Yeats), ou seja, por essa beleza terrível que brota de uma poesia em que as estórias subalternas são reprimidas. Sendo assim, as visões estéticas de "belo" e "sublime" se fundem de modo a dar vazão a um ser incriminado tanto por seu ofício, quanto por sua história. Portanto, ao contrário de Yeats, que destrói ambas as categorias em nome do nacionalismo ${ }^{115}$, Heaney reescreve ambos os conceitos na égide da culpa.

\section{O EXÍlio E A CULPA}

Ao remanejar tensões estéticas, históricas e psicológicas, o poema se assemelha a um rito de passagem, onde a subjetividade em formação, após passar por uma provação, ganha contornos políticos. Entretanto, a herança literária incorporada não pode ser absorvida por completa porque está em um espaço problemático de transições, em que, apesar de não haver um período bem definido, ou até mesmo um espaço bem contornado, todas as experiências retornam à questão histórica de sua terra de origem. Com isso, exatamente na metade do poema, essa passagem, por meio da rememoração, reintegra no "choque" a "experiência" benjaminiana, fazendo dessa:

\footnotetext{
114 "distinguished from the passive acceptance of a code... negative indentity into positive... multiplicity of the being". Os trechos citados foram retirados das obras de W. B. Yeats e citados pelo crítico. Para Michael Hamburger a adoção de Máscaras para Yeats era a forma pela qual Yeats respondia às tensões da modernidade. A luta entre o self e o anti-self alarga a lacuna entre subjetividade empírica e imaginativa. (HAMBURGER, 1969, p. 74-5)

115 De acordo com Lloyd: 'Uma terrível beleza nasce'. É uma frase que imperiosamente desmorona duas categorias estéticas fundamentais, o sublime e o belo... Na estética tradicional, essas duas categorias são sistematicamente distintas em todos os seus elementos: o sublime se refere ao domínio masculino da produção e transcendência evocada na resposta ao terror da morte e à potencial dissolução da subjetividade; a beleza, por outro lado, é relegada a esfera feminina da reprodução, tanto literariamente e no sentido de reprodução harmoniosa de formas sociais. Ambos os nacionalismos cultural e militante interessam a uma versão do sublime, buscando transcender a morte, até mesmo na morte, por identificar-se a uma vida maior da nação que estão produzindo. (LLOYD, 1993, p. 73)
} 
um fato da tradição, tanto na vida coletiva, como na particular. Consiste não tanto em acontecimentos isolados fixados exatamente na lembrança, quanto em dados acumulados, não raro inconscientes, que confluem na memória (BENJAMIN, 1989, p. 30)

Por meio da "memória" que retoma a experiência de vida na peregrinação, Heaney retoma a sua própria tradição poética e como essa possui a dúbia missão de apagar e reescrever histórias.

A respeito disso a crítica Clair Wills afirma:

'Act of Union' torna-se uma luta entre o feminino primitivo, territorial e situado e o masculino social e organizado, que gera os habitantes da bastarda província da Irlanda do Norte. Como um bastardo híbrido e dividido entre fragmentos de sua personalidade, o poeta emprega a voz materna confirmadora contra a ordem simbólica e patriarcal, moldando seu discurso de resistência com duas espécies de linguagem; uma natural, enraizada no solo, ligada ao poder vivo do discurso, e a outra arbitrária, masculina e estrangeira (WILLIS, 2000 pp. 50-1) ${ }^{116}$

Assim, o autor começa a reintegrar no escopo de seu trabalho as personagens que são apagadas da sociedade contemporânea em que vive. Nesse sentido, a polifonia vocal que acontece nessa parte do poema tem a função de estabelecer a subjetividade poética como exilada, ou seja, dentro e fora dessa história, perto e afastada, sujeito e não-sujeito; em outras palavras, compreendê-la em um nível maior de complexidades. Com isso, ele, novamente, passa a imaginar seu retorno como algo que o impulsiona para um novo exílio e a questão da adoção de versos provindos de outras tradições literárias torna-se a assimilação de outras histórias; ou seja, memórias do mundo romano e italiano, são conectadas ao seu contexto por carregarem a marca da colonização.

De modo a criar um nexo entre a primeira parte de "Station Island" e a segunda, o poeta constrói um continuum histórico entre a questão da subjetividade culpada - por ter aceitado o exílio - e a apropriação colonial da Irlanda. Nesse momento, ao adicionar as

\footnotetext{
116 Texto que faz parte do livro Improperties: Politics and Sexuality in Northern Irish Poetry (1993) em que a autora, na parte dedicada a Heaney, afirma que ao adotar a simbologia da terra como "mãe", o poeta retoma o confronto entre uma feminilidade original e uma masculinidade colonizadora. Original: "The 'Act of Union' becomes a struggle between primitive, landed, situated femininity and rational, social, organised masculinity which creates the inhabitants of the bastard province of Northern Ireland" "sets the self confirming mother tongue against the patriarchal symbolic order" "two species of language; one natural, rooted in the soil, connected to the living power of speech, the other arbitrary, male, alien". (WILLIS, 2000 pp. 50-1)
} 
vozes literárias às subalternas de sua experiência, Heaney retoma os Troubles e o seu exílio, sendo que um é causa do outro. Com isso, valendo-se da tercina, o metro contínuo da Divina Comédia, o poeta retrata primeiramente o assassinato de um jogador de futebol dono de uma venda que foi abordado por terroristas durante a violência da Guerra Civil. Se no poema anterior o eu poético retoma Dante em nível temático e antropofágico, nessa seção, ele o retoma em nível formal, demonstrando que, ao invés de uma progressão para o "Purgatório" e o "Paraíso", ele estaria, de fato, retornando ao "Inferno", visto que - assim como disse a Master Murphy - os anos de escola já foram um purgatório suficiente. Contudo, ao invés de expurgar seus pecados, esse purgatório potencializa sua culpa, visto que o ato amoroso da parte IV produz desassossegos por remeter à violência da Irlanda colonial. No início da parte VII, o poeta, mergulhado no "Inferno" da história e inundado pela culpa, observa seu reflexo na água. Como uma presença dessa culpa imanente, Heaney visualiza a imagem refletida desse cidadão, cuja história subalterna, foi apagada durante os atentados terroristas. Esse jogo de reflexos e imagens sugere que a vítima poderia ter sido o próprio poeta.

A retomada do metro de Dante faz com que o poema apresente uma virtuosa simetria matemática baseada no número três: as estrofes de dez sílabas, com três linhas cada, rimam da forma $\mathrm{ABA}, \mathrm{BCB}, \mathrm{CDC}, \mathrm{DED}, \mathrm{EFE}, \ldots$, ou seja, a linha central de cada terceto controla as duas linhas marginais do terceto seguinte. Ao fazer com que cada tercina antecipe o som que irá ecoar duas vezes no terceto seguinte, a estrutura representa um movimento contínuo e incessante. Apesar de o terceto ser usado em toda a seção VII, ele, por vezes, se distancia do ritmo em meio a alexandrinos, octassílabos, eneassílabos e até mesmo versos com treze sílabas poéticas. A rima também muda de foco em alguns momentos, principalmente quando o espectro ensangüentado toma voz e conversa com o poeta. Com isso, compreendemos que o poeta apropria-se da estrutura do "Inferno" dantesco e retoma, metaforicamente, o presente histórico com o qual convive. Dentro dessa paisagem bucólica e amorosa da parte VI, surge o afastamento e, por consequiência, o exílio trazendo experiências traumáticas e irremediáveis na seção VII.

Dentre essas, o trágico martírio lírico e a dramaticidade exacerbada são as características que fazem o autor retomar o tema do exílio. Para Edward Said (2001, p. 55), as tintas carregadas, combinadas à obstinação e exagero, fazem parte de sua natureza 
"contrapontística". Segundo o crítico, o fato de Dante ter transposto seus conflitos políticos à eternidade, revela o quão vigorosa, em termos pessoais e sociais, a obra é. Da mesma forma, James Joyce forjou ininterruptamente uma querela com a Irlanda de modo a dar força à sua vocação e a projetos artísticos (SAID, 2001, p. 55). Se na obra de Heaney ambos os artistas têm grande valor como fonte de inspiração e são corporificados pelo poema, logo compreendemos que ao invés de fazê-lo transcender aos sentimentos universais, o exílio coloca o poeta no rumo da história Irlandesa, evocando as vítimas dos confrontos entre o Exército Republicano Irlandês e a polícia inglesa. Sobre o solitário sentimento trazido pela guerra civil, Heaney atesta:

emoções exaustivas e destorcidas que desenrolam como anzóis em linha de pesca. Sinto-me cansado dos julgamentos que variam entre agonia e injustiça. Em uma hora, agitado pela longa cauda da raça e do ressentimento, em outra, pelo adequado sentimento de terror e piedade. Nós vivemos sob a doentia luz dos monitores de TV, com o retalho do egoísmo entre nós e o sofrimento. Sobrevivemos a explosões e funerais, e convivemos com as famílias das vítimas, aqueles fragmentados e isolados. (HEANEY, 1980, p. $30)^{117}$

Com o seguinte relato, que é concluído pelo enigmático sonho do poeta com uma das vítimas - "estava me barbeando no espelho quando olhei para o espelho e vi um homem ferido, debruçando-se em mim, com suas mãos erguidas para me ferir ou implorar" (HEANEY, 1980, p. 33) $)^{118}$ - o poeta demonstra toda ambigüidade e indecisão em relação às circunstâncias históricas que se desenrolam a sua frente.

Ao usar a métrica de Dante como pano de fundo para a história simbolizada pela Beatriz de Heaney, entendemos que ambos os subalternos - a mulher e o vendedor - são agentes que historicizam a narrativa, aparentemente mítica, deflagrando a violência do norte e trazendo ao primeiro plano a exploração colonial. Da mesma maneira, a métrica contribui para essa revitalização, pois é como se a própria violência do Norte fosse algo infindável e deixasse os moradores da cidade em constante estado de alerta. As próprias

\footnotetext{
${ }^{117}$ Heaney descreve a época de Natal em Belfast no ano de 1971. Original: ... weary twisted emotions that are rolled like a ball of hooks and sinkers I am fatigued by a continuous adjudication between agony and injustice, swung at one moment by the long tail of race and resentment, at another by the more acceptable feeling of pity and terror. We live in the sickly light of TV screens, with a pane of selfishness between ourselves and the suffering. We survive explosions and funerals and live among the families of the victims, those blown apart and those in cells apart. (HEANEY, 1980, p. 33)

118 Original: I was shaving at the mirror of the bathroom when I glimpsed in the mirror a wounded man falling towards me with his bloodied hands lifted to tear at me or implore. (HEANEY, 1980, p. 33)
} 
quedas de rimas e expansão de pés poéticos representam essa retomada de fôlego, como se algo perturbador estivesse para acontecer. Assim, ao longo dos vinte e oito tercetos, o fantasma causa uma inquietação potencializada por seu sangue e pela maneira violenta que morreu. Novamente, a simbologia do número deve ser levada em consideração, visto que vinte e oito seria o número de passos da Via Crucis de Jesus Cristo multiplicada por dois. Se por um lado o relato do autor é proferido em relação ao Natal, cuja essência traz sentimentos de renascimento e renovação, por outro lado a realidade com a qual ele se depara se aproxima do sofrimento da cruz multiplicado em intensidade e continuidade, pois a métrica não deixa o leitor afastar-se dessa desolação e falta de esperança. Embora as imagens do poema não correspondam exatamente àquelas propostas pela igreja, compreendemos que o relato do dono da venda - e fantasma - é a sua estação.

Nessa sétima estação, a questão do deslocamento de histórias e contextos rompe igualmente estruturas geográficas e históricas, principalmente porque Heaney retoma dois lugares que, mesmo tendo sua relação fixa com um local geográfico, são atemporais e não demarcados. Enquanto na estrutura de Dante, Heaney encontra-se imageticamente no "Inferno", ao retomar os passos finais de Jesus, ele retorna à Jerusalém. Contudo, ele não está em nenhum dos dois lugares por estar à beira do lago Derg, recordando Belfast, cidade que tem o poder de trazer o sofrimento em sua versão até mesmo infernal, dado o senso de alienação da população frente ao problema local imposto pela guerra civil:

Um problema que durante 1979 parecia que poderia ser contornado e, talvez, resolvido, em grande parte, dentro das seis províncias da Irlanda do Norte, não seria mais... A minoria católica estava num humor profundamente alienado, não propensa a, depois de uma década de desilusão política, dar apoio inquestionável e permanente a políticos constitucionais cuja moderação garantiu apenas poucas concessões tangíveis e não trouxe benefício aos seus constituintes. (BROWN, 2004, p. 324) ${ }^{119}$

\footnotetext{
${ }^{119}$ O historiador reserva um capítulo de seu livro para descrever senso de incerteza e dúvida gerado pela década de 1980 na Irlanda. Original: "A problem that throughout the 1970s seemed as if it could be contained and perhaps resolved, largely within the framework of the six countries in Northern Ireland, no longer appeared so... Northern Catholic nationalist minority there was in a deeply alienated mood, disinclined after a decade of political disillusionment to give permanent, unquestioned support to moderate constitutional politicians whose moderation had won few tangible concessions and had brought no benefits to their constituents". (BROWN, 2004, p. 324)
} 
Além de ser um lugar onde as histórias concretas são desviadas e recontadas a partir dos olhos da imaginação e fantasia, o tempo cronológico é, da mesma maneira, totalmente desconstituído. Embora ambas as estratégias literárias sejam comumente relacionadas a uma fuga da realidade, a nosso ver, elas têm a capacidade de refletir a falta de esperança e senso crítico da época, tal como descritos pelo crítico e historiador Desmond Fennell:

Ao passarmos pela recessão dos anos 70 e começo dos anos 80, com o governo se endividando para manter o partido, enquanto o desemprego crescia semanalmente e o Norte fazia barulho, as pessoas pareciam entorpecidas, como sonâmbulas, e tinham medo de pensar. Conversas fiadas sobre desemprego, rendas e preços, falências das finanças, escândalos políticos, divórcio, aborto e violência do Norte preenchiam o ar. (FENNELL, 1983, pp. 15-6) ${ }^{120}$

O entorpecimento social do qual fala Fennell, somado à culpa de ter deixado a Irlanda do Norte, fazem com que Heaney leia sua situação histórica e, por conseguinte, condição subjetiva, por meio do sonho e da indeterminação de espaço e tempo. Entretanto, o binômio da distância e proximidade só poderá ser revelado através das questões postas pela linguagem, como instância que caracteriza a sua identidade. Sobre a temática do tempo, o filósofo medieval Santo Agostinho levanta uma hipótese pertinente: se para ser denominado tempo o presente deve, necessariamente, tornar-se passado, o passado só poderá ser evocado por meio da linguagem. Em suas palavras:

ainda que se narrem os acontecimentos verídicos já passados, a memória relata, não os próprios acontecimentos que já decorreram, mas sim as palavras concebidas pelas imagens daqueles fatos, os quais, ao passarem pelos sentidos, gravam no espírito uma espécie de vestígios. Por conseguinte, a minha infância que já não existe presentemente, existe no passado que já não é. Porém, a sua imagem, quando a evoco e se torna objeto de alguma descrição, vejo-a no tempo presente, porque ainda está em minha memória. (AGOSTINHO, 2000, p. 326) ${ }^{121}$

\footnotetext{
${ }^{120}$ Para Fennell, o problema básico da Irlanda era a falta de uma identidade bem definida, após a recessão das décadas anteriores. Original: "As we passed on through the recession of the " 70 s and early ' 80 s, with the government borrowing wildly to keep the party going somehow, while unemployment grew weekly and the North rumbled on, people seemed dazed, like sleep-walkers, and were afraid to think. Chatter about unemployment, wages and prices, and bankruptcy of the finances, political scandals, divorce and abortion, and Northern violence filled the air". (FENNELL 1983, pp. 15-6)

${ }^{121}$ Se por um lado o poeta não deixa clara sua relação com Santo Agostinho, os mecanismos utilizados pelo poeta se assemelham às dúvidas e questões colocadas pelo filósofo medieval. Como a peregrinação também tem algo de muito religioso e reflexivo, a própria correlação com tais idéias não se faz de uma maneira
} 
Assim, ao presentificar a noite em que o fantasma morre, a partir da unidade lingüística de outrem, e assumindo a voz do espectro, Heaney representa um dilema subjetivo em que a ausência da história da Irlanda se faz presente no que não a define: Beatriz, Dante, a tercina e a via crucis. Com isso, há em sua memória vestígios dispersos dessa história em que o passado é sempre presente, e o lugar, uma passagem seqüencial de metáforas onde o autor procura expurgar a culpa de ter se ausentado no momento do conflito civil. As repetidas des-culpas ao dono da venda no final do poema carregam algo de infinito e perene, como se, mesmo pedindo perdão, a palavra e seu ato artístico fossem uma constante confissão. Sendo assim, a linguagem é, não só a maneira pela qual o sujeito supera o trauma da separação de sua terra natal, mas também uma compensação pela perda da perda da realidade pelo afastamento do exílio.

De acordo com Slavoj Zizek, Lacan afirma que o sujeito, quando traumatizado pelas imprevisíveis saídas da mãe, começa a construir uma operação imaginária de distância e proximidade com um carretel de linhas. Ao representar simbolicamente essa situação, o carretel que se afasta e retorna torna-se precisamente a parte da sua subjetividade sacrificada para que ele entre na ordem Simbólica da linguagem. Essa, portanto, a recompensa pela perda da realidade imediata (a substituição de "coisas" por "palavras"), mas o lembra da sua perda inicial. Nossa compreensão é que Heaney, para superar a perda da "mãe" Irlanda e, logicamente da parte da sua subjetividade supressa com o exílio, usa as operações de transposição - a métrica e as outras personas - de modo a superar o trauma de ter-se afastado de sua terra, e, logo da realidade cotidiana da guerra civil. Assim, o fantasma e a métrica de Dante são substituições de sua própria subjetividade através da linguagem poética. (ZIZEK, 1993) ${ }^{122}$ Nesse Sentido, a aparente fuga, é, na verdade, uma tentativa simbólica de, por meio da confissão, “conhecer em [si] mesmo [sua] verdade, mas igualmente de contá-la de mostrá-la e de reconhecê-la como verídica" ${ }^{123}$, porém sempre mediado pela figuração poética.

mecânica, mas pela semelhança entre as tensões postas pelas Confissões e aquelas colocadas pelo poema. Em ambas a culpa é uma constante. (AGOSTINHO, 2000, p. 326)

${ }^{122}$ Para Slavoj Zizek, a perda da realidade pelo sistema Simbólico de Lacan faz com que o sujeito não consiga ser redimido pela linguagem, pois essa apresenta a divisão primeira de sua subjetividade completa. (ZIZEK, 1993, pp. 45 - 124)

${ }^{123}$ Michel Foucault, em entrevista a J. François e J. Witt, explica a função da confissão. Para ele, "a confissão é uma noção fundamental sobre nossa maneira de ser, ligada ao que chamo de obrigações com relação à 
A respeito do tema em "Station Island", Terence Brown afirma que, dada a culpa sentida por Heaney por não ter seguido completamente as tradições familiares e da sua comunidade, a absolvição seria somente alcançada por meio da poesia que recobra o caráter social de testemunho:

no seu livro de 1984, Station Island, e particularmente, no título seqüência, em que seus sentimentos de culpa sobre sua carreira artística e papel poético trazem à tona o material de sua poesia. Em 'Station Island'... o poeta confronta os sentimentos de culpa como uma série de fantasmas do passado da Irlanda e seu também. Eles conversam com ele com uma autoridade e convicção que a sua poesia posterior não tende a apresentar. Eles proferem uma acusação formal, como se o poeta esperasse uma exoneração de um tipo kierkegaardiano, ao rememorar o professor obscuro que recorda o grande conforto em saber que perante Deus, estamos sempre na direção errada. $\left(\right.$ BROWN, 1982, p. 56) ${ }^{124}$

Com isso, mesmo presente em toda a peregrinação de Heaney, a culpa nesse momento é mais acentuada, pois, além de pedir três vezes desculpas ao fantasma, ele também assume sua posição de exilado.

\section{A VIOLÊNCIA E CULPA}

Atentando novamente para comparação numérica entre estações, observamos que, enquanto a sétima representa a segunda queda do Cristo, a sétima do poeta demonstra uma dupla queda: aquela que acontece quando ele observa seu reflexo no espelho das águas e compreende que poderia, assim como o fantasma que o visita, ter sido morto por atentados terroristas - tanto da parte irlandesa, quanto da inglesa - e aquela que o deixa impotente

verdade... o problema consiste em saber se esse laço com a verdade sobre o que nós somos conhece uma força específica própria ao Ocidente cristão. Essa questão toca a história da verdade e da subjetividade no Ocidente". (FOUCAULT, 1999, pp. 302-3)

${ }^{124}$ Terence Brown aborda o tema da culpa como uma constante vital na obra de Heaney, como ele próprio afirma no início do artigo: "From the start Seamus Heaney has seemed oddly guilty about being a poet at all". (p. 182) Original: It is in his 1984 volume, Station Island, and particularly in the title-sequence, that his guiltfeelings about his artistic career and his poetic role surface clearly as matter for poetry. In "Station Island"... the poet confronts those guilt-feelings as a series of ghosts from his own and Ireland's literary past. They addressed him with an authority of tone and conviction that his poetry had latterly tended to lack. They proffer a comprehensive indictment, as if the poet hoped for exoneration of a Kierkegaardian kind, as he brings to mind the gloomy Dane who once recorded that our greatest comfort is in knowing that before God we are always in the wrong. (BROWN, 1982, p. 56) 
dada a decisão de deixar sua comunidade em um momento delicado. Se dividirmos a seção VII em quatorze unidades compostas de duas estrofes, observamos perfeitamente a via crucis do "shopkeeper" assassinado. Ademais, podemos notar ainda que o fantasma narra sua última noite vivo durante quatorze estrofes, sugerindo uma transposição entre passado e presente dentro da própria subdivisão identitária do sujeito poético. Contudo, por mais que o poeta tente completar novamente sua subjetividade perdida ao dar voz ao sujeito subalterno reprimido na escrita colonial, o seu material artístico não the permite, pois a própria materialidade das palavras, como ato Simbólico de substituição, carrega o resquício do material histórico do sofrimento.

\footnotetext{
I had come to the edge of the water, soothed by the just looking, idling over it as if it were a clear barometer or a mirror, when his reflection did not appear but I sensed a presence entering into my concentration on not being concentrated as he spoke my name. And though I was reluctant I turned to meet his face and the shock

Is still in me at what I saw. His brow was blown open above the eye and blood had dried on his neck and cheek. 'Easy now',

he said, it's only me. You've seen man as raw after a football match... What time it was when I was wakened up I still don't know (O. G. p. 255)
}

Como podemos observar a partir do trecho citado, na primeira e segunda pequena cena constituída pelas quatro primeiras estrofes, o leitor observa a aparição do fantasma contada na voz de Heaney. Porém, esse assume a voz poética através do silêncio do poeta provocado por seu chocante rosto banhado por sangue coagulado. Neste momento, temos uma polaridade entre a vítima e o poeta: enquanto um sofreu em vida os efeitos da guerra civil, o outro permaneceu intacto devido à saída do país. Esse silêncio é extremamente expressivo pois é a maneira pela qual a linguagem poética não consegue encontrar placidez para lamentar a morte da vítima, nem meios para transcender essa realidade, pois ela encontra-se a sua frente e, ademais, ensangüentada, provando sua realidade. 
Em sua análise sobre o conceito do Belo em Kant, Derrida (1998, pp. 289-90) descreve que a poesia deleita através de uma universalização sistemática de vozes distintas. Assim, experiências díspares tornam-se comuns e geram um prazer desinteressado e fluído. Em outras palavras, a hetero-afeição (hetero-affection), transforma-se em auto-afeição (auto-affection). Contudo, para o filósofo, existe ainda um "prazer negativo", provocado pelo retorno, ou, em suas palavras, do "vômito" de certos conteúdos que impedem a realização da "idealização poética transcendental" kantiana. Nesse caso, temos o sacrifício da identificação pela diferenciação, e o não digerido retorna através de um outro não assimilável. Em nossa visão, no instante em que o espectro se apresenta ao poeta manchado de sangue (algo não apagado em um mundo transcendental dos espíritos), ele pode ser identificado como esse outro não assimilável, que evita o prazer do belo, mas retoma a história apagada pelos documentos oficiais. Desse modo, temos a possibilidade de leitura do subalterno como aquele que adia a harmonia poética e se inscreve na alteridade ${ }^{125}$ do sujeito. Por conseqüência, surge um eu poético, além de culpado, também angustiado e cindido, pois sua tentativa de embelezar o sofrimento por meio da métrica de Dante, é destruída pela materialidade do sangue e da carne daquele que toma o seu lugar. Com isso, temos uma poética que traz a superfície os elementos históricos desse subalterno de uma maneira realista e verdadeira ao impacto dos fatos traumáticos da guerra.

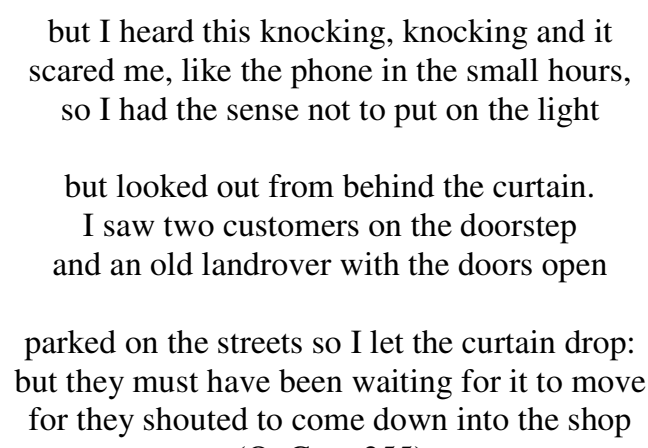

(O. G. p. 255)

A partir do trecho, na continuação das cenas, o espectro assume a fala por meio de pentâmetros jâmbicos perfeitos e atesta não lembrar da hora exata em que fora desperto por seus algozes, apenas de que havia fregueses na porta clamando para que abrisse. Ele

125 Para Derrida seria o vômito, ou o mal-gosto, que desestabiliza o sujeito e impede o idealismo transcendental, ou seja, que o faz vincular a sua experiência à do outro. (Derrida, 1998, pp. 289-90) 
também enumera alguns objetos dispersos que contribuem para a pintura de um cenário desolador e fantástico: vemos um carro abandonado de portas abertas, provavelmente prenúncio de uma bomba, e a ausência de pessoas na rua, salvo as poucas que o chamavam. Toda atmosfera fantasmagórica, somada à indeterminação de tempo, espaço e sujeito poético fazem com que esse cenário seja exatamente o elemento do qual surgem os vários traumas e medos provocados pelos confrontos civis. Isso seria um prenúncio de "esquizofrenia"126 como um grau zero do qual pode-se acessar várias estruturas sociais. Sendo assim, a ordem cronológica que já havia sido suspensa anteriormente cede espaço a concatenações abstratas e alegóricas das quais brotam ecos de fatos históricos. A primeira alegoria diz novamente respeito à figura feminina redentora: Maria.

Enquanto a mãe de Jesus o acompanha em todo seu calvário e o encontra na quarta estação, o dono da venda também possui a sua acompanhante, a esposa. Porém, ao contrário do silêncio resignado de Maria, essa apresenta o desespero de quem pressente a morte ao se contorcer na cama. Suas reclamações abalam o dono da venda que tenta acalmá-la ao abrir a janela e pedir para que os perturbadores aquietem sua gritaria (racket). Em contrapartida, eles usam o pretexto de uma criança doente para que ele desça, trazendo talvez pílulas (pills), ou pó (powder), ou algo em uma garrafa (something in a bottle). $\mathrm{O}$ primeiro eixo de interligação de todos esses elementos está no fato de que todos podem ser metáforas para instrumentos bélicos: as pílulas podem ser balas de revólveres, o pó pode significar pólvora e as garrafas podem ser uma provável alusão às bombas caseiras que eram jogadas nas ruas de Belfast. Outro nexo de ligação é que todos esses elementos criam uma nova intertextualidade: na voz da vítima, o autor retoma o poema "Serenades", de Wintering Out (1972) em que representa os conflitos entre o Exército Republicano Irlandês (I.R.A.) e a Força Policial Inglesa (R.U.C.). Por meio das imagens de aves, que expõe sua dúvida perante os atentados, o poeta mostra as contradições entre pensamento racional, simbolizado pela coruja, e atitudes violentas (a explosão de bombas caseiras), caracterizadas pelo racket do corvo e o morcego. Por fim, com a imagem da codorna, o

\footnotetext{
${ }^{126}$ Galgado nas teorias de Deluze e Guattari, Fredric Jameson compreende a esquizofrenia como um fluxo de onde as estruturas sociais emanam. Sendo assim, a partir de estruturas desconexas em relação a espaço e tempo, a sociedade começa a ganhar contornos definidos. A partir desse esquema, o crítico problematiza os conceitos de selvagem, bárbaro e civilizado. (JAMESON, 1987, p. 124-5).
} 
poeta explicita sua vontade de ausentar-se desse clima opressor e do questionamento da mídia acerca de suas lealdades.

Ao contrário de uma resistência aberta em que a voz do poeta, como a do rouxinol, continua cantando uma poesia contrária à violência e à experiência do terror, aqui a "gritaria" não é de contestação, mas de imobilidade e impossibilidade. Desta maneira o barulho, assim como o medo da mulher, a loucura do homem ao abrir a porta, e a desculpa de que há uma criança doente, resultam em um final trágico. A décima terceira estrofe, exatamente aquela em que surge a mentira em relação à criança, é o ponto culminante da passagem pois a métrica se rompe de todas as formas possíveis, as rimas não seguem a mesma seqüência anterior e os pés chegam a treze sílabas poéticas. Novamente, temos uma alegoria numérica com o número de apóstolos (somando Jesus), e a sua traição - parece que o fantasma também conhecia seus assassinos. Se por um lado as personagens dessa passagem parecem literalmente esquizofrênicas por falarem através de enigmas e símbolos aparentemente desconectados da realidade, temos a revelação de um mundo no estado de barbárie, em que a exaustiva codificação lingüística (overcoding) (JAMESON, 1987, p. 125) retoma a falta de alternativa dos sujeitos. Desta maneira, a realidade não consegue se apreendida como tal, e os sujeitos agem como se não pertencessem a lugar nenhum.

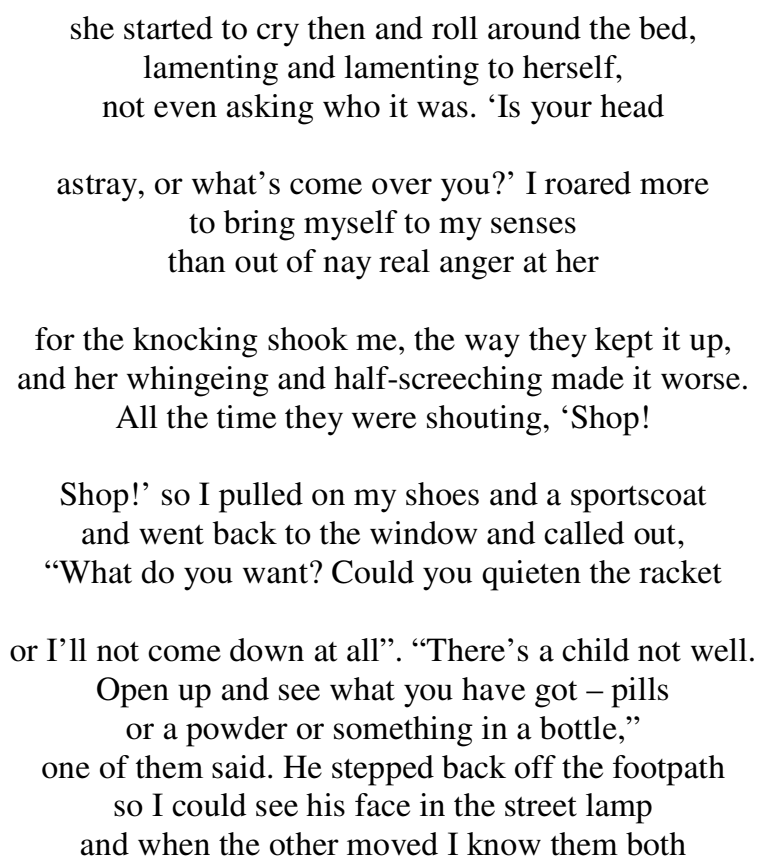

(O. G., p. 256) 
A alegorização do final da narrativa do fantasma a partir da história de Cristo é concluída quando ele se despede de sua companheira. Embora haja uma paz momentânea provocada pelo gesto de amor expressa pelo verso "algo me fez achegar e segurar-lhe a mão", o assassinato é consumado quando ele sente o cheiro de carne podre. A intertextualidade com a narrativa Bíblica torna-se ainda mais incisiva quando ele mente para a esposa dizendo conhecer aqueles que batem. Enquanto Simão Pedro, um dos discípulos mais importantes na caminhada de Jesus, mente sobre a sua fé para salvar sua vida, esse "espectro" de Jesus é assassinado por confiar, mesmo acreditando ser estranho o fato de eles não procurem um farmacêutico. Com isso, se por um lado o poeta tenta expurgar sua culpa espelhando-se no exemplo deste homem que acreditou ser possível uma criança estar precisando de cuidados, o seu sacrifício pessoal espelharia a sua imagem em Deus. Sendo assim, a polifonia que acontece nessa parte é ainda de sujeitos, que se espelham e se refletem uns nos outros. Mesmo desejando ser igual a Heaney, pois após sua narrativa o dono da venda fala em tom informal com o poeta, ele, na verdade, reafirma sua essência divina como um "espectro" do próprio Cristo.

Deste modo, temos uma intertextualidade com a história de Cristo em nível "espectral", ou seja, na ausência e presença. De acordo com Derrida:

o espectro é uma forma de presença e o virtual é também uma espécie de presença. Simplesmente percebe-se que a oposição presença/ausência não funciona mais de maneira tranqüilizadora quando se trata do virtual e do espectral... o espectral está relacionado ao retorno dos mortos e ao luto. O espectral é o que transita entre o mundo dos vivos e o dos mortos, o presente e o ausente. Portanto, o valor de espectralidade é por si próprio desconstrutor, uma força que atrapalha o crer na presença. (DERRIDA, $2001)^{127}$

De modo a problematizar a sua própria noção de experiência e colocar o cidadão comum no centro da sua poética, Heaney constrói imagens em nível especular que se aproximam do "espectro" de Derrida. Desta maneira, esse subalterno é projetado como um campo de força forjado a partir da simbologia cristã: se Deus está espelhado em três pessoas- Pai, Filho e Espírito Santo - o poeta, nessa estação, está espelhado em três pessoas - a subjetividade, o "espectro" e Jesus. Desta mesma maneira, a facção divina

${ }^{127}$ Conceito desenvolvido por Derrida que se refere ao conceito de solidariedade. Elaborações feitas a partir do Capital de Karl Marx. (Derrida, 2001) 
estaria, não naquele que acolhe a narrativa, mas naquele que a conta livremente e segue os preceitos de solidariedade, assim como Cristo flagelado, seguindo a vontade de Deus e anulando seus próprios medos e aflições.

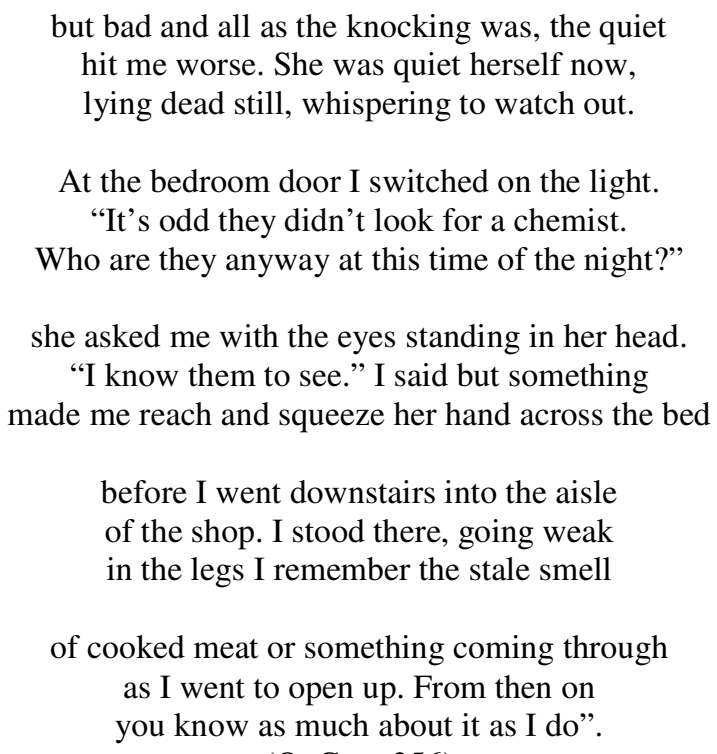$$
\text { (O. G, p. 256) }
$$

Após o relato, o poeta tenta fazer perguntas sobre a natureza dos indivíduos: seriam eles ingleses (uniformizados?), seriam eles do I.R.A. (mascarados?), ou não teriam relação com nenhum dos dois grupos (de cara limpa?). Contudo, o fantasma prefere não responder, e apenas replica, comentando que o poeta havia engordado, desde o início de seu namoro no carro Austin ("Ministry of Fear", North (1972)). Heaney então faz uma pequena digressão de três estrofes descrevendo o asseio do dono da venda, como um atleta que mantém a sua aparência jovial mesmo após a morte. Dado o seu tormento de observar esse ser ausente e presente deflagrando sua culpa, em uma atitude contemplativa, o poeta afirma ser ele uma "vítima perfeita, limpa e inconcebível", ou seja, tão digno de adoração quanto o próprio Cristo. Portanto, ele tem necessidade de pedir perdão três vezes ao fantasma, algo como uma atitude espectral da negação tripla de Pedro: primeiro ele pede desculpas por sua indiferença, depois por seu envolvimento tímido, e por último, por seu olho. Entretanto, o fantasma parece não estar mais preocupado com tal contexto e, afirmando que "tudo está além de sua compreensão", se esvai em uma onda de calor e dor. Pedir desculpas por seu olho é um dado expressivo, pois é através deste que o poeta acolhe imagens que ficarão retidas em sua memória e serão expressas pela linguagem. Com isso, retornamos à culpa 
pela própria atividade poética e verificamos que, através da revelação da supressão do subalterno nas narrativas históricas factuais, o poeta expurga sua culpa por ser escritor.

Mais do que penitência, o olhar o mundo a partir dos olhos do outro - Heaney observa o fantasma no lago ao observar-se - proporciona ao poeta solidariedade e compreensão. Ao estar em um lugar atemporal e a-geográfico, o poeta está, na verdade, aproximando-se e se envolvendo mais profundamente em sua comunidade. Logo, nesse segundo momento de seu exílio, o poeta despedaça sua personalidade e a costura na égide do sacrifício, violência e religião. A dignidade conferida às vítimas é tamanha, que ele sente a necessidade de reverenciá-las como verdadeiros mártires. No entanto, é ainda intrigante a questão de ele reverenciar essa vítima, sendo que ela mesma é transplantada para a sua poética. Se por um lado ele deseja destacá-la em sua poesia, por outro ele também deseja ser reverenciado por ser alguém que pertence a essa comunidade, mas que fora desvinculado dela pelo seu exílio. A lamentação de não conseguir ser um herói mitológico, como expressa em "Exposure" (North, 1969) ${ }^{128}$, é retomada, e o poeta sente-se novamente desolado por não atender às necessidades mais imediatas de sua comunidade. A sua única realização é a de registrar tais fatos e recontá-los na sua própria voz. Assim, a paz momentânea, como era vista no diálogo com o professor secundário, é rompida e a culpa retorna.

Did they say anything?" "Nothing. What would they say?"

"Were they in uniform? Not masked in any way?"

They were barefaced as they would be in the day.

Shites thinking they were be-all and the end-all".

"Not that it is any consolation

but they were caught, "I told him", "and got jail"

Big limbed, decent, open faced, he stood Forgetful of everything now except

Whatever was welling up in his spoiled head

beginning to smile. "You've put on weight

since you did your courting in that big Austin you got the loan of on a Sunday night

Through life and death he had hardly aged.

There always was an athlete's cleanliness

shining off him and except for the rawaged

${ }^{128}$ Para a análise completa do poema "Exposure” (North, 1972), cf. Annunciação, 2004/ 2005. 
forehead and the blood, he was still the same rangy midfilder in a blue jersey

and starched pants, the one stylist on the team,

the perfect, clean, unthinkable victim.

Forgive the way I have lived indifferent -

forgive my timid circumspect involvement

I surprised myself by saying, "Forgive

"My eye", he said, "all that's above my head".

And then in a stun of pain seemed to go through him

And he trembled like a heatwave and faded.

(O. G., p. 267)

\section{A VIOLÊNCIA E O OLHAR ONÍRICO}

Na parte VIII do poema, Heaney volta seus olhos para duas pessoas simbólicas em sua formação profissional e pessoal: seu amigo arqueólogo, Tom Delaney, morto precocemente, e o primo Colum McCarthney cujo assassinato é descrito no poema "The Strand of Lough Beg" de Field Work (1979). A subdivisão do poeta entre o arqueólogo, que morre aos 32 anos, e o primo, que é vítima de um atentado, é outro dado importante, pois ele está retomando a guerra civil à luz da escavação e de um dado sentimental - ambas as personas tiveram seu ciclo de vida interrompido por algum motivo. Sendo assim, ele retorna à exploração do presente com base no passado, como ele fizera em um dos livros mais importantes, North (1975). A continuação do recorte do seu exílio com a recuperação, predominantemente, de pessoas mortas retoma, mais do que a culpa, a ausência de não ter estado presente o quanto poderia com aquelas pessoas. Tamanho é seu remorso, que o poeta sente-se completamente impotente frente às acusações que são proferidas por seu primo.

Ao mesmo tempo em que Heaney conversa com Tom e Colum durante o poema, ele está, de fato, dormindo, ou seja, todo diálogo que acontece nessa parte - após o assassinato do dono da venda que aparece realmente como um fantasma - pertence ao reino dos sonhos. Portanto, ao colocar a cena no nível do inconsciente, o autor projeta o seu exílio para uma ausência que almeja ser recuperada em negativo pela presença e pelas desculpas que pede aos entes queridos. Dessa maneira, ele ecoa as palavras que Adorno profere em relação à escrita de poesia: "escrever poesia lírica depois de Auschwitz constitui um ato 
bárbaro; isso exprime, em termos negativos, o estímulo que inspira a arte engajada" (ADORNO, s/ data, p. 34). Compreendemos então não que a lírica seja em si um ato bárbaro, mas consiste em nos lembrar que "nunca houve um monumento da cultura que não fosse também um monumento da barbárie. E, assim como a cultura não é isenta de barbárie, não é, tampouco, o processo de transmissão da cultura". ${ }^{129}$ Após ouvir as duras palavras de seu primo e do amigo, o poeta finalmente compreende o quanto poderia ter feito, ao menos por sua família, se não tivesse se ausentado por tanto tempo. Portanto, a atitude bárbara não é da poesia, mas sua, pois ao invés de ter transmutado a sua tímida participação em um ato pontual, ele suaviza os fatos com a beleza da linguagem.

Se por um lado toda parte VIII desautoriza a preocupação artística com a poesia, uma vez que ele não é capaz de enfrentar a morte e muito menos embelezá-la, por outro lado, o poema parece ressaltar a importância desta diante da realidade bárbara resultante da história sectária e colonial irlandesa. Desta maneira, observamos um complexo mecanismo, em que a ausência do poeta - exílio - é uma presença, que afirma questionando - as vozes que o interrogam - a validade da poesia. A posição do indivíduo torna-se um pouco intrincada, pois se seguirmos a linha de pensamento freudiano, cuja base está no fato de que um sonho pode representar a manifestação de um desejo, mesmo que as operações punitivas do superego estejam atuando no interior da psique da pessoa, ${ }^{130}$ entendemos que esse sonho aproxima-se de um outro desejo frustrado: o de estar presente no momento da morte dos dois. Portanto, a noção freudiana do sonho, no caso de Heaney, atrela-se à de Jacques Lacan, o qual acredita que o desejo aponta para uma nova substituição e combinação de significados, através de processos metafóricos e metonímicos, em outras palavras, esse sonho não será apenas a manifestação de um desejo, mas aponta para um desejo que está em outro lugar. (LACAN, 1992, pp. 226 - 281)

\footnotetext{
${ }^{129}$ Teses em que Walter Benjamin rompe com a noção de que a história é uma seqüência de fatos em rumo ao progresso e à evolução. Ele propõe que a história é um ciclo em que o passado traumático está sobreposto ao presente e não deixa de imprimir suas marcas no futuro. (BENJAMIN, 1996, p. 225).

${ }^{130}$ Compreendemos, de acordo com Freud, que a satisfação de um desejo não é dada de maneira imediata, visto que muitos sonhos trazem pensamentos e memórias dolorosas. Com efeito, o sonho protege aquele que sonha da angústia que tais pensamentos provocam. Em suas palavras: "the disguised fulfillment of a suppressed wish... is the obvious fulfillment of a suppressed wish. Anxiety is the mark which shows that the suppressed wish showed itself stronger than the censorship, that it put through its wish-fulfillment despite the censorship, or was about to put it through". (FREUD; STANLEY, 1920, p. 183)
} 
Em uma atitude psicológica carregada de tensões internas, o poeta assume a posição de um peregrino cansado e atormentado pelos espíritos de seus amigos. Porém, se atentarmos para o fato de que os acontecimentos da seção VIII ocorrem em frente à imagem de Santa Brígida, ${ }^{131}$ cuja função foi reformular a deusa celta do fogo, protetora da poesia e das viagens, devemos igualmente fazer uma leitura do sonho a partir da óptica celta, que, igualmente, tem sua presença demarcada na simbologia da peregrinação. No imaginário celta, os espíritos dos mortos têm o poder de voltarem ao mundo através dos sonhos. Aqui, esses se manifestam na subjetividade do poeta e, falando através de sua voz, sobrevivem para além de suas impressões. De acordo com John Arnott MacCulloch, citando o imperador romano César:

Os druidas desejam, em particular, difundir a idéia de que as almas não morrem, mas passam de uma para outra (ab aliis ... ad alios) depois da morte, e por causa disso, eles estimulam o heroísmo, o medo da morte ser negligenciada'... Diodoro complementa que ...'prevalecia dentre eles a idéia de que as almas dos homens eram imortais, e depois de completar seu ciclo de existência, esses viveriam novamente, e suas almas passariam para outro corpo. Portanto, no funeral dos mortos, alguns jogavam cartas endereçadas aos parentes mortos na pira funerária, acreditando que os mortos as leriam no outro mundo. (MACCULLOCH, 2003, p. 335) ${ }^{132}$

Além da visão científica, há a visão religiosa atormentando o poeta. Desta maneira, sendo os conflitos postos em termos opostos como arte e barbárie, sonho e realidade, consciente e inconsciente e mortos e vivos, as estrofes também retratam essa pluralidade de questões que obedecem à lógica do próprio sonho. As sete extensas divisões estróficas variam entre três e dezessete versos cada uma, sugerindo que se por um lado há uma

\footnotetext{
${ }^{131}$ De acordo com Lawrence J. McCaffrey: "the cult of Saint Brigid, the Mary of the Gael, is built on one of the important Celtic goddesses with the same name, meaning "the high one". She was the patron of poetry, music, and especially fertility. Saint Brigid's 'Life is the oldest account of an Irish saint, written in the middle of the seventh century by Cogitosus of Kildare (Brigid's city), where the Church of Saint Brigid was a double monastery with one section for nuns and another for monks. The monastery may have been ruled by a female bishop who later became an abbess with a male coadjutor bishop as her assistant. Saint Brigid 's feast day was celebrated on February 1, the old Celtic feast of Imbolc, which, stressing fertility, marked the "beginning of the lactation of the ewes." (HACHEY, T., et. al., 1996, p. 4)

${ }^{132}$ Livro em que o autor examina as práticas e culturas celtas baseado em registros escritos do Império Romano. Original: The Druids in particular wish to impress this on them that souls do not perish, but pass from one to another ( $a b$ aliis ... ad alios) after death, and by this chiefly they think to incite men to valour, the fear of death being overlooked."... Diodorus says: "Among them... the souls of men were immortal, and after completing their term of existence they live again, the soul passing into another body. Hence at the burial of the dead some threw letters addressed to dead relatives on the funeral pile, believing that the dead would read them in the next world. (MACCULLOCH, 2003, p. 335)
} 
economia de trocas lingüísticas entre as personas, por outro, há uma expansão das mesmas. Novamente, a representação numérica da Via Crucis é retomada, porém nesse contexto, ela absorve os mortos que vivem através do sonho e do inconsciente de Heaney. Enquanto nas três primeiras estrofes observamos a subjetividade dirigindo-se ao arqueólogo, e rememorando os últimos momentos que poderia ter estado presente, nas quatro últimas está presente o diálogo do poeta e o primo, que o acusa agressivamente de estar em um congresso no momento de sua morte. Seu ódio é reforçado quando acusa o poeta de escrever um poema suavizando a violência de seu assassinato

Valendo-se de uma motivação cuja essência é dúbia - tradições celtas e santos católicos - o poeta descreve na primeira estrofe o seu encontro com o arqueólogo. Em tom familiar, com uma métrica mais solta e flexível - entre dez e doze sílabas poéticas - o poeta descreve a aparição do arqueólogo no leito de oração com uma face sorridente e reta, porém, assim que ele surge, uma chuva negra o encobre e ele desaparece. Essa imagem faz com que ele permaneça, nas próximas duas estrofes, recordando os últimos momentos que teve com o amigo. Dentre as principais escavações que Tom fizera, as mais importantes são aquelas em que ele descreve como as reminiscências históricas do passado medieval foram encobertas pelas novas paisagens urbanas modernas. Contudo, em uma das pesquisas em busca de resquícios de uma igreja medieval, ele acaba encontrando destroços de uma urna pertencente à Idade de Ferro, ${ }^{133}$ fato que provavelmente influenciou Heaney nas suas metáforas para a situação de guerra civil da Irlanda do Norte à luz de um passado mais remoto ainda.

Após a passagem dos peregrinos entre eles, Heaney é reportado - como em um flashback - para o hospital em que Tom passou seus últimos momentos. Nesse contexto, a nuvem negra traz o passado de volta ao presente onírico da peregrinação e as luzes que pulsam sob a tela do hospital - "your heartbeats, Tom" - desnudam a verdade para o poeta. Resta-nos compreender quais são essas verdades reveladas pelo arqueólogo, que fazem com que o poeta não tire os olhos de suas batidas do coração representadas pela máquina ao lado de sua cama. A resposta é dada na continuação da estrofe, quando ele associa a sua ida a Dublin à culpa de não ter se despedido como deveria do velho amigo. O autor sente-se

133 Informações gerais sobre as pesquisas de Tom Delaney, podem ser encontradas na página: http://www.excavations.ie/Pages/HomePage.php. (Consultado em 07/ 11/ 2006, às 12h30.) 
verdadeiramente como um traidor, cujo conhecimento é limitado a apenas meias verdades, ou seja, fragmentos assim como os colocados no poema, ou até mesmo os estilhaços de sua própria memória, de que recobra apenas partes. Porém, por serem semelhantes aos estilhaços das bombas e dos fuzis, farão com que ele tenha uma idéia mais completa e inteiriça da realidade.

\author{
Nothing at all. But familiar stone \\ had me half numbed to face the thing alone. \\ I loved my still-faced archeology. \\ The small crab-apple physiognomies \\ on high crosses, carved heads in abbeys... \\ Why else dig in for years in that hard place \\ in a muck of bigotry under the walls \\ picking through shard and Williamite cannon balls? \\ But all that we just turned to banter too. \\ I felt that I should have seen far more of you \\ and maybe would have - but dead at thirty two! \\ Ah poet, lucky poet, tell me why \\ What seemed deserved and promised passed by? \\ (O. G., p. 259)
}

Explorando a sua sociedade a partir da relação com o amigo, o arqueólogo responde ao poeta. Em uma mudança imediata de foco, o leitor fica sem saber precisamente se a nuvem negra se dissipa, ou se é até mesmo o poeta que fala. Porém, é mais provável que Delaney esteja dialogando com Heaney e afirmando que a sua arqueologia poderia ser comparada com a do poeta, mas mesmo assim, aquela feita pelas palavras ainda é mais "sortuda". Com isso, há uma reiteração da acusação, pois o amigo critica o escritor por ter estado em uma posição confortável de exílio. Contudo, ele ainda reflete a situação daquele que sempre permaneceu em sua terra e nunca observou a Irlanda de um ponto de vista distanciado. Sobre o assunto, Edward Said afirma que é comum por parte daqueles que não têm a experiência do exílio, acreditar que essa é uma simples fuga. Em suas palavras:

O exílio é o modelo para o intelectual que é tentado e até atacado ou pressionado, pelas recompensas da acomodação, do dizer o sim, do mudarse. Até se a pessoa não é mesmo um imigrante ou expatriado, é ainda possível pensá-lo como, pode-se investigar, apesar das barreiras, e sempre se mover das centralidades autoritárias rumo às margens, onde se vê coisas que são geralmente perdidas na mente que nunca viajou além do convencional e confortável. (SAID, 1992, p. 124) ${ }^{134}$

\footnotetext{
${ }^{134}$ Said começa a desenvolver aqui suas teorias a respeito do exílio e do intelectual. Essas primeiras explorações dão origem ao artigo que nos baseamos para escrever nossas hipóteses. Original: Exile is a model
} 
Embora a Irlanda do Norte não seja um lugar onde as categorias convencional e confortável possam ser aplicadas, a postura acusadora assumida pelo arqueólogo reflete, de uma maneira simplista, a posição de alguém que é absorvido por ideologias políticas.

Além de constatar essa característica um tanto quanto determinista de sua personalidade, o arqueólogo pergunta ao poeta o porquê tudo o quanto era prometido e merecido o ignorou. Vemos nessa pergunta retórica, acoplada a uma falsa promessa religiosa, um pessimismo e desespero típico da guerra, ou seja, a visão de que a liberdade não pode ser atingida nem pela subjetividade, nem pela sociedade, pois ambos encontramse em meio ao fogo cruzado das questões políticas. Na próxima estrofe, o poeta recorda uma estátua que lhe fora presenteada pelo amigo - a imagem medieval de uma abadessa encontrada nas escavações. A resposta do poeta - "your gift will be a candle in our house" - perfeitamente metrificado em pentâmetro jâmbico, representa algo sólido que não deixa de atormentar, e de ser uma presença consoladora na sua casa. O costume de colocar velas nas casas também é algo que Heaney comenta no seu artigo "Belfast", visto que, como forma de protesto contra a repressão, os cidadãos não montavam árvores de natal, mas deixavam uma vela na janela, simbolizando a luz que guiaria a sagrada família para suas casas.

\section{Segundo Heaney:}

Ao invés da árvore de Natal, que estará deliberadamente ausente de muitas casas, as pessoas colocarão a tradicional vela na janela. Eu me recordo de Louis MacNiece 'nascido na ordem anglicana, banido para sempre das velas dos irlandeses pobres'; e de W. R. Rogers, cujos Poemas Selecionados surgiram na época do Natal; e de John Hewitt, aquele nascido no Ulster, no estoque de Planter, cuja poesia, ao longo dos anos, foi uma exploração da consciência Protestante do Ulster. Todos esses homens nasceram para a idéia de 'duas nações' e parte de seu esforço imaginativo foi para resolver seus sentimentos em relação à Irlanda... como protestantes do norte, cada um dos três, de maneiras diferentes, exploraram a relação da porca que come seus filhotes. Eles não se dispersaram, ou reivindicaram outro ninho. Embora eu

for the intellectual who is tempted, and even beset and overwhelmed, by the rewards of accommodation, yeasaying, settling in. Even if one is not an actual immigrant or expatriate, it is still possible to think as one, to imagine and investigate in spite of barriers, and always to move away from the centralizing authorities toward the margins, where you see things that are usually lost on minds that have never traveled beyond the conventional and the comfortable. (SAID, 1992, p. 124) 
nunca na vida tenha visto um filhote ser comido pela porca: o que acontece realmente é que os porcos mais novos comem as orelhas uns dos outros. (HEANEY, 1980, p. 33) ${ }^{135}$

Altamente perspicaz em sua afirmação, o poeta, ao colocar a vela no centro da estrofe, retoma, com isso, a tradição das velas de natal, e os poetas que, mesmo tendo lutado para definir uma linha de resistência perante a homogeneização colonial, não foram aceitos pelos excluídos. Ao descrever os fatos dessa maneira, Heaney se desvincula de Joyce - a Irlanda como a porca que come os filhotes - e coloca o seu ideal que, pela falta de união, os próprios "irmãos filhotes" machucam uns aos outros, ou seja, ao comerem as suas orelhas, eles se tornam surdos aos apelos racionais.

Novamente, temos a polifonia poética impulsionada pela idéia de conforto do exílio, criando ambigüidades no próprio centro do poema. Se, para Terence Brown, MacNeice difundiu a idéia de que a Irlanda estava em uma situação dúbia ao decretar a autosuficiência, mesmo ainda estando ligada à economia britânica, Edna Longley argumenta sobre MacNiece e Hewitt que:

sua posse imaginativa da Irlanda é limitada ao fato de que essa pode ser disputada. Porém, eles não se renderam à idéia que os seus trabalhos 'defendam a alma irlandesa', como a nacionalista fé ortodoxa. Seja... fazendo pequenos ataques sobre a água (MacNiece), ou defendendo um 'canto' irlandês do norte (Hewitt) eles não perderam a crença que... 'os católicos podem salvar a si mesmos, mas os protestantes devem salvar a nação. (LONGLEY, 1994, p. 54)

\footnotetext{
${ }^{135}$ Original: "Instead of a Christmas tree, which will be deliberately absent from many homes, people will put the traditional candle in the window. I am reminded of Louis MacNiece 'born to the Anglican order, banned for ever from the candles of the Irish poor'; and of W. R. Rogers, whose Collected Poems have appeared in time for Christmas; and of John Hewitt, that Ulsterman of Planter stock whose poetry over the years has been an exploration of the Ulster Protestant consciousness. All three men were born to a sense of 'two nations' and part of their imaginative effort was a solving of their feelings towards Ireland... as Northern Protestants, they each in different ways explored their relationship to the old sow that eats her furrow. They did not hold apart and claim kin with a different litter. Although I have never seen farrow eaten by a sow in my life: what happens is that the young pigs eat one another's ears". (HEANEY, 1980, p. 33)

${ }^{136}$ Parte do livro em que Longley examina a continuidade dos ideais nacionalistas de Yeats na poesia de Louis MacNeice e John Hewitt. Original: “Their imaginative possession of Ireland is hedged, to varying degrees, by awareness that it might be disputed. Yet they have not quite surrendered to the idea that their works do as much to 'defend Ireland's soul' as does orthodox Nationalist faith. Whether... making occasional raids from across the water (MacNiece), or securing a Northern 'corner' (Hewitt), they have not utterly lost ... the belief of William Drennan, Belfast Presbyterian United Irishman, that 'The Catholics may save themselves, but it is the Protestants that must save the nation". (LONGLEY, 1994, p. 54)
} 
Nesse sentido, Heaney problematiza a própria questão irlandesa, trazendo à tona seu primo, cuja morte, por mais bela e áurea que tenha se tornado no seu poema "The Strand of Lough Beg", é fruto de um confronto de uma nação que deseja se libertar, mas que ainda carrega impulsos messiânicos.

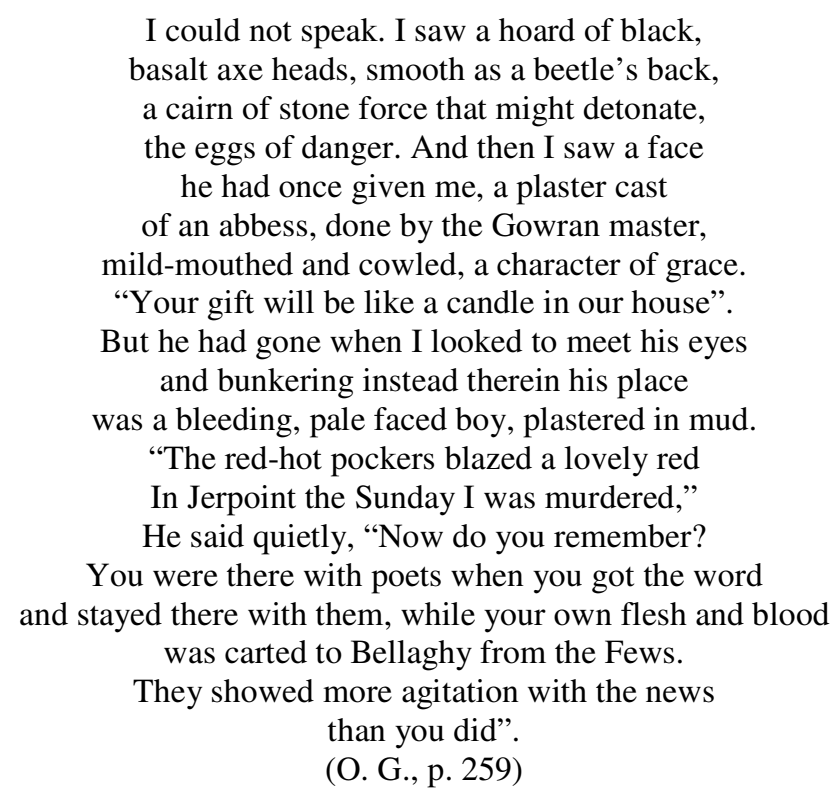

Em meio ao confronto lírico da vela na janela que pode trazer algo de esperançoso ao poeta, surgem as cortantes acusações de Colum. Ao colocar versos poéticos na boca do primo, ele tece o seu primeiro argumento ao redor do qual todas as críticas giram: o fato de Heaney estar em uma reunião de poetas enquanto ele estava sendo assassinado. Extremamente irado com a covardia do primo de não ter se comovido tanto quanto a mídia, Colum traz à tona toda culpa que o poeta tenta expurgar na peregrinação. Mais do que anular seus sacrifícios, ao fazer pentâmetros jâmbicos perfeitos, ele chama sua atenção, pois essa parece ser a única linguagem que ele entende. Logo, se por um lado, a assimilação dessa métrica representa uma resistência de Heaney perante uma lírica que o sufoca, na óptica do espírito de Colum essa é uma simples assimilação que o afasta dos acontecimentos concretos - tanto de sua família, quanto da política. Embora o poeta tente argumentar com o primo, dizendo que se sente culpado, assim como as margens de um rio seco, ele permanece impassível em suas denúncias, pois acredita que sua escrita evasiva não consegue abarcar o sentimento desolador de ter perdido a vida cedo - assim como muitos. 
"But they were getting crisis

first-hand, Column, they had happened in on live sectarian assassination.

I was dumb, encountering what was destined".

And so I pleaded with my second cousin.

"I kept seeing a grey stretch of Lough Bed and the strand empty at daybreak.

I felt like the bottom of a dried-up lake".

"You saw that, and you wrote that - not the fact. You confused evasion and artistic tact.

The protestant who shot me through the head

I accuse directly, but indirectly, you

Who now atone perhaps upon this bed

For the way you whitewashed ugliness and drew the lovely blinds of the Purgatorio

and saccharined my dead with morning dew".

Then I seemed to waken out of sleep

Among more pilgrims whom I did not know drifting to the hostel for the night.

(O. G., pp. 260-1)

A análise que Colum faz dos poemas de Heaney representa as dúvidas e incertezas do poeta, principalmente porque toca no ponto nevrálgico de sua arte: a de representar a realidade em viés, ou seja, não há um tratamento direto do objeto histórico, mas uma distorção, a partir do ponto de vista individual. O estudo mais interessante sobre o assunto é o de Adorno, pois ao fazer uma nova distinção entre a obra "tendenciosa" e "engajada", ele critica abertamente as primeiras por serem uma redução estética da matéria real para a concretização de um ideal político, e valoriza as segundas, que, ao serem fiéis somente aos materiais artísticos que as constituem "destroem o destruidor, que simplesmente existe, e que, por esta simples existência, reitera infinitamente a culpa" (ADORNO, s/ data, p. 35). Nesse sentido, Heaney, através do retorno de um conteúdo reprimido pelo seu consciente, assume a culpa de apenas escrever. Contudo, essa escrita, como Adorno reitera:

obedece às forças dessa mesma realidade [empírica], as quais, ao mesmo tempo, renegam estas criações intelectuais e atiram-nas de volta à sua própria realidade. Não existe nenhum conteúdo material... de uma criação artística que não tenha se originado na realidade empírica da qual ela se furta (ADORNO, s/ data, p. 35). 
Ao aproximar-se das teses proferidas pelo filósofo, Heaney confere uma profundidade a sua obra, desvinculando-a de interpretações políticas imediatas e simplistas que não enxergam um potencial interpretativo na questão formal.

Deste modo, colocando tais acusações na boca de seu primo, e não propriamente na sua, o autor proporciona uma subdivisão psíquica em que, no inconsciente, o seu ego subdivide-se e reprime violentamente o seu comportamento. O poeta, portanto, deseja uma idealização, ou seja, ser aquele herói que poderia ter resgatado seu primo, contudo ele perde essa oportunidade e pode apenas "açucarar" artificialmente esse fato por meio da poesia. Esse procedimento poético, que tem suas raízes na psicanálise, faz com que a subjetividade crie um confronto entre a arte com pretensões sociais de não negar o mundo, e outra que deseja libertar-se da dor e reproduzir a fruição estética universal. Sobre o assunto, Freud escreve:

o aparecimento múltiplo do ego em um pensamento desperto, especialmente quando o ego se divide em sujeito e objeto, coloca uma parte de si mesmo como uma instância observadora e crítica em contraste com a outra, ou compara sua natureza atual com o passado relembrado, que outrora também foi ego. (FREUD, 1976, p. 152) (137 $^{13}$

Portanto, a subjetividade, ao mesmo tempo em que é Colum, é Tom e é Heaney, ou seja, essa polifonia de vozes cria uma personalidade múltipla que transparece a essência da arte de Heaney: uma instância mediadora entre o mundo e realidade. Além do mais, nesse momento, ele deixa por completo a intertextualidade literária - o que chamamos de antropofagia - e abraça a absorção espectral.

Em face dessa constatação chegamos a uma interpretação sobre a própria questão da culpa do poeta. Como Heaney não se rende a uma comunicação política imediata, mas filtra essa realidade através da sua subjetividade, ele produz um conhecimento do mundo por meio da tensão formal; ou seja ao cristalizar um momento histórico específico, ele comunica seu impacto subjetivo. Além disso, cremos que o exílio seria uma outra forma de distanciamento pelo qual o poeta consegue apreender essa realidade histórica. Se por um lado, o poeta deseja se isolar e compreender a sua sociedade, ela implementa-se nos

\footnotetext{
${ }^{137}$ Em suas notas sobre o sonho, o psicanalista afirma que o sonho, por não conseguir abarcar o pensamento abstrato, sempre se remete a materiais concretos. (FREUD, 1976, p. 152)
} 
materiais artísticos com o qual ele trabalha e o obriga a, duramente, trabalhá-los. Como Adorno afirma

a verdade do assunto está em esperar que a arte vá contra a sua natureza e simplesmente duplique a sua existência, a sua tarefa face a face é meramente existir, é ser sua essência e imagem. Isso somente constitui a estética; a arte não se torna conhecimento em referência à realidade mais imediata, como por exemplo, fazendo justiça a uma realidade que encobre sua própria essência e anula sua verdade em favor à suas leis formais, não por aceitar passivamente objetos como eles se revelam. Em arte, a estética é mediada completamente. (ADORNO, 1980, p. 159) $)^{138}$

Ao discutir sua condição de existência, a poética de Heaney aponta para o exílio. Já as intertextualidades, para a sociedade. Com essa exploração, que tem início no artigo "Reconciliation under duress: the architecture of Seamus Heaney's recent poetry" de Steven Matthews (MATTHEWS, 1997), ${ }^{139}$ abordamos a obra do poeta a partir de um nível mais complexo: o artigo de Adorno. Ao explorar o tema de como o poeta representa o momento histórico, o crítico consegue uma visão que leva em consideração a temática do engajamento e como o poeta, a partir dessa, consegue ganhar um distanciamento que o possibilita transcender e compreender as diversas camadas de sentido propostas por sua poesia mais recente. Ao sugerirmos o distanciamento colocado pelo exílio, avançamos ainda mais um passo nessa discussão, pois esse distanciamento é algo que penetra na forma e nos temas abordados pelo poeta. Esse, por sua vez, será uma multiplicação de desejos, os quais, através da culpa posta pelo sonho, produz um desejo ainda maior do outro - de fundir-se no sofrimento e nas pessoas que tivera a experiência da violência. Em razão disso, ele continua a sua peregrinação encontrando mais vítimas.

$\mathrm{Na}$ sua relação entre o sujeito, o Outro e o desejo, o psicanalista Jaques Lacan afirma:

\footnotetext{
${ }^{138}$ Artigo em que Adorno vai contra as idéias de uma arte realista e socialista proposta por Lukács. Na sua visão, a arte não pode ser reduzida formalmente para realizar projetos ideológicos. Original: "The truth of the matter is that except where art goes against its own nature and simply duplicates existence, its task vis-à-vis that which merely exists, is to be its essence and image. This alone constitutes the aesthetic; art does not become knowledge with reference to more immediate reality, i.e. by doing justice to a reality which veils its own essence and suppresses its truth in favour of a merely classificatory order. Art and reality can only converge if art crystallizes out its own formal laws, not by passively accepting objects as they come. In art knowledge is aesthetically meditated through and through". (ADORNO, 1980, p. 159)

${ }^{139}$ Artigo que se assemelha com nossa linha de pensamento, visto que o autor aproxima a questão do exílio, com a política. (MATTHEWS, 1997, pp. 158-186)
} 
o estado de ignorância no qual o homem permanece em relação ao seu desejo, não é tanto uma ignorância, mas o lugar desejado por ele. Isso é o que quero dizer com a fórmula de que o inconsciente é um 'discours de l'Autre' (discurso do outro), em que o de deve ser entendido no sentido de do Latino (determinação objetiva)... Mas devemos acrescentar que o desejo do homem é o désir de l'Autre (desejo do Outro)... isso é o porquê da questão do Outro, que retorna ao sujeito do lugar no qual ele espera uma réplica profética para alguns como a forma 'Che vuoi?', 'O que você quer?' é aquilo que o direciona melhor para o caminho do seu desejo. $\left(\right.$ LACAN, 1992, p. 312) ${ }^{140}$

Sendo assim, esse sujeito que fornece subsídios para o autoconhecimento, reflete com base no Outro a sua própria experiência. Contudo, ao invés dessa ser prazerosa e compreensiva, ela produz, mais questionamentos, até mesmo obscuros e intrigantes, com relação aos rumos de sua arte, e de uma comunicação inacessível - e condenada por aqueles que precisam dela.

Concluímos, portanto, afirmando que essa seção, cuja interpretação nos leva a compreender o exílio como uma multiplicidade de pessoas, que, presentes na ausência do poeta, ganham contornos em sua mente e subjetividade, produzindo um desejo infinito do outro. Sendo assim, enquanto a intertextualidade com os autores importantes do cânone, o leva a uma antropofagia literária - o relato das vidas perdidas - cria um diálogo espectral, produzindo, por sua vez, uma aporia da culpa. Entretanto, longe de vincular-se somente a um caráter etéreo e melancólico do distanciamento, o poeta sofre com as vítimas, na medida em que elas penetram em sua personalidade, destruindo a possibilidade de uma arte fundada nela mesma, mas que, ao tratar da sua condição de existência, reflete sobre a sua natureza essencial e trágica no contexto político da Irlanda do Norte. Logo, não se tem uma solução, mas uma série de questões imbricadas nessas pessoas que o poeta encontra. A questão do sonho e da luta interna dentro da subjetividade artística não produz uma expurgação da culpa, mas uma potencialização dessa, em que o exílio, a forma e o conteúdo

\footnotetext{
${ }^{140}$ Seminário em que Lacan discute, a partir das categorias de Freud, uma nova maneira de encarar o inconsciente. Para ele, este estaria relacionado à dialética Hegeliana, em que o Outro constitui o sujeito, e a compreensão desse Outro leva ao melhor entendimento de si próprio. Original: "For it is clear that the state of nescience in which man remains in relation to his desire is not so much a nescience as to where he desires. This is what I mean by my formula that the unconscious is 'discours de l'Autre' (discourse of the other), in which the de is to be understood in the sense of the Latin de (objective determination): de Alio in oratione (completed by: tua res agitur). But we must add that man's desire is the désir de l' Autre (the desire of the Other)... That is why the question of the Other, which comes back to the subject from the place from which he expects an oracular reply in some such form as 'Che vuoi?', 'What do you want?' is the one which best leads him to his path of his own desire”. (LACAN, 1992, p. 312)
} 
são camadas de significados - assim como as trufeiras - em que o autor constrói sua personalidade múltipla e conflituosa. 


\title{
3. A CONSCIÊNCIA DO RETORNO?
}

\author{
"I am not yet born; O fill me \\ With strength against those who would freeze my \\ humanity, would dragoon me into a lethal automaton, \\ would make me a cog in a machine, a thing with \\ one face, a thing, and against all those \\ who would dissipate my entirety, would \\ blow me like thistledown hither and \\ thither or hither and thither \\ like water held in the \\ hands would spill me.// \\ Let them not make me a stone and let them not spill me. \\ Otherwise kill me". \\ (MACNEICE, 1986, p. 113)
}

O terceiro e último movimento do poema "Station Island", constituído pelas quatro últimas seções por meio das quais o poeta se apropria de pessoas e objetos do passado, cria uma lírica distanciada que interliga passado e futuro à luz do olhar polifônico e intertextual. Em outras palavras, a estética que o poeta esboça é da subjetividade que, ao invés de aprisionada em múltiplas personalidades que o acusam de, ora desejar, ora concretizar a sua saída da Irlanda do Norte, pretende, baseada em todas as facções de si mesmo, descrever uma lírica que tenha apelo ao local e ao global, ou seja, engatar o vagão de sua lírica nos trilhos de uma ordem mundial interconectada. Todavia, ao invés de colocar sua lírica no terreno ideológico da globalização, ele compreenderá como essa - a partir do dado da diferença local, do subdesenvolvimento e do avanço rumo ao primeiro mundo - pode resistir a um mecanismo que destrói a própria humanidade. É fato que a concretização desse projeto só se dá no livro District and Circle (2006), mas esse só é possível porque o presente poema ajuda Heaney a compreender como a sua trajetória esteve paralela a um movimento histórico das margens ao centro, e como este centro é corrompido e reconstituído pelas margens.

Dadas as especificidades de cada momento histórico, no presente capítulo, pretendemos perceber como é resolvido o embate entre subjetividade e exílio e, na conclusão, compreender como essas tensões se resolvem no recente volume poético de 
Heaney, o qual sem perder sua humanidade, confere um caráter utópico a sua herança poética - para justificar a epígrafe de Louis MacNeice. Já aqui continuaremos a explorar porque o poeta coloca em um mesmo movimento o grevista da fome Francis Hughes, objetos do passado, o poeta místico João da Cruz e James Joyce como constituintes de uma nova fase poética que deve ser voltada, concomitantemente, para o sujeito multifacetado após a culpa do exílio e para a cultura que se transforma rapidamente. Nossa hipótese é que o poeta sugere, por meio da coexistência de todas essas categorias em um mesmo tempo e espaço, uma renovação do pensamento público e cívico, de onde possa surgir uma resposta mais participativa da população. Outra interpretação possível é a de que o autor esteja mapeando o chão de uma cultura cuja imagem anoréxica e idealizada precise ser destruída para que haja um renascimento exterior e interior. Entretanto, ao passar da anorexia de Hughes para o misticismo de Juan de La Cruz - partes IX à XI - o poeta não consegue se sustentar subjetivamente, portanto, é necessária a visão crítica de James Joyce.

\section{A FOME: RECUSA CONSCIENTE OU PRIVAÇÃO FORÇADA}

$\mathrm{Na}$ parte IX observamos que, ao invés de estabelecer um prelúdio para começar a conversa com Francis Hughes, ${ }^{141}$ o poeta assume a voz do prisioneiro e inicia o poema com sua interlocução. Contrariando a estrutura das seqüências anteriores, pela primeira vez o poeta usa desse artifício de modo a denunciar, desde o início, o grau de mudança que essa última parte poderá trazer. Uma das razões mais imediatas para antropofagia do subalterno histórico é a sua própria fome, dada ao avanço do percurso de peregrinação (em completo jejum) e a uma fome metafórica de compreender a atitude de um grevista que fora, ao mesmo tempo, vítima e algoz. Dentre os documentos históricos que relatam a biografia do prisioneiro, não é possível encontrar um consenso, muito porque se para alguns ele era considerado um herói, cuja resistência perante o governo britânico foi incisiva e heróica,

\footnotetext{
${ }^{141}$ Em 27 de Outubro de 1980, na prisão de Maze, sete prisioneiros republicanos Raymond McCartney, John Nixon, Sean McKenna, Brendan Hughes, Leo Green, Thomas McFeeley e Thomas McKearney recusam-se a comer, pois reivindicam tratamento diferenciado. Embora a situação de colonização os considerasse presos perigosos, por terem se envolvido em confrontos armados, eles exigiam serem tratados como prisioneiros políticos. Em 18 de dezembro de 1981, Bobby Sands, (o mais noticiado grevista da fome) em Belfast, começa a sua greve, acompanhando-o logo em seguida Francis Hughes que dá inicio ao seu protesto em Derry. (O’MALLEY, 1990, p. xi)
} 
para outros, era apenas um fanático que promovia medo e terror nas ruas da Irlanda do Norte. Muito claramente, porém, a primeira estrofe exibe o desperdício de uma vítima em razão das circunstâncias históricas, assim como a do dono da loja que foi assassinado, como vimos no capítulo anterior. Entretanto, ainda existe um caráter problemático em sua personalidade pois, de modo a resistir à colonização da Irlanda do Norte e a subjugação irlandesa, Francis Hughes acabou por se destruir. Sobre a natureza multifacetada da resistência promovida pelos grevistas da fome, David Lloyd argumenta:

O que desejo argumentar sobre esse ponto é que essas ações precisam ser compreendidas como eventos que ocorrem na interface entre formações culturais não-modernas e aparatos penais modernos, na verdade, largamente pós-modernos. O local imediato de interface é o corpo do prisioneiro e a cela, mas apenas à medida que ambas as partes não pareçam delimitadas ou dadas, mas profundamente estruturadas pelo Estado e pela cultura. Isso também não deve ser compreendido como uma simples oposição entre a cultura não-moderna dos prisioneiros e a mistura de cultura moderna e pósmoderna dos aparatos penais: pelo contrário, é precisamente a instabilidade e multiplicidade de relações possíveis e o envolvimento militar da instabilidade que motiva os protestos a todo momento. (LLOYD, 1999, p. $59)^{142}$

Como um personagem histórico cujas ideologias de uma nação estavam divididas entre diferentes lealdades e complexas identificações, Francis Hughes personifica o passado e presente dentro de sua própria constituição interior e exterior, visto que o poeta insiste em sua fragilidade física. Ao unir-se aos prisioneiros que faziam greve de fome devido à exigência de um tratamento penitenciário mais digno e humanizado para aqueles pertencentes às facções do Exército Republicano Irlandês, ele afirma:

Tenho maior orgulho de dizer que fui privilegiado em lutar pelo povo irlandês e pela Irlanda. Se eu tenho um dever, vou levá-lo a cabo até o fim,

\footnotetext{
${ }^{142}$ Sobre os grevistas da fome, David Lloyd ressalta que a sua resistência era ambígua, pois havia em sua constituição uma incoerência entre pragmatismo e ativismo, ou seja, a morte das vítimas acabava por incorporar um ideal heróico fetichizado e absorvido por ambas as partes do conflito. Original: "What I would to assert at this point is that these actions need to be understood as events that occur on the interface between non-modern cultural formations and a modern, indeed, largely postmodern, penal apparatuses. The immediate site of the interface is the body of the prisoner and the cell, but only insofar as those are not seem as delimited and given but as themselves already profoundly structured by state and culture. Not should this be understood to suggest that there is a simple opposition between a non-modern culture of the prisoners and the mixed modern and postmodern culture of the penal apparatuses: on the contrary, it is precisely the instability and multiplicity of possible relations and the tactical deployment of that instability which informs the protests at every moment". (LLOYD, 1999, p. 59)
} 
com a certeza inabalável de que somos uma raça nobre, e de que correntes e limites não fazem parte de nossa constituição (HUGHES, 2006) ${ }^{143}$

Outros ainda relatam que, no instante de sua morte, ouviram Hughes clamando pelos amigos, "camaradas", e exultando: "aquele que morre pela Irlanda vive". Com isso, podemos entender o quanto o garoto que nascera no condado vizinho ao de Heaney e cujos pais eram amigos da família do poeta, compreende sua luta como uma resistência dignificante para sua terra e o meio pelo qual pode ser transformado em um verdadeiro guerreiro mitológico. No entanto, contrastando com essa imagem mítica, o grevista da fome é, na voz do poeta, uma pessoa comum que expressa o seu medo, sua fraqueza após a recusa em se alimentar e suas memórias de quando era guerrilheiro da Irlanda do Norte. A métrica eximiamente trabalhada com rimas intercaladas e pés poéticos jâmbicos, proporciona um solo de dúvidas, cuja essência mimetiza igualmente o tratamento desumano que recebera e o próprio aprisionamento subjetivo do poeta. Embora haja a liberdade artística para variar ritmos, semelhante à idéia de liberdade no pensamento de Francis, Heaney deseja aproximar-se do aprisionamento físico, logo, ele apreende a métrica em uma forma fixa.

My brain dried like spread turf, my stomach Shrank to a cinder and tightened and cracked. Often I was dogs on my own track

Of blood on wet grass that I could have licked.

Under the prison blanket, an ambush

Stillness I felt safe in settled round me.

Street lights come on in small towns, the bomb flash

Come before the sand, I saw country

I knew from Glenshane down to Toome

And heard a car I could make out years away

With me in the back of it like a white-faced groom.

A hit man on the brink, emptied and deadly.

When the police yielded my coffin, I was light As my head when I took aim.

(O. G., p. 261)

Como visto no trecho citado, esse confronto formal é reforçado pelos sons plosivos e oclusivos que aproximam dos ruídos de bombas em lugares fechados, ou seja, uma

\footnotetext{
${ }^{143}$ Site da internet em que há textos exaltando o caráter heróico dos "hunger strikers". Original: I have no prouder boast to say I am Irish and have been privileged to fight for the Irish people and for Ireland. If I have a duty I will perform it to the full with the unshakable belief that we are a noble race and that chains and bounds have no part in us. Hughes, Francis. Republican POW, Long Kesh. 10 $0^{\text {th }}$ of March, 1981. In. irelandsown.net/fhughes.htmlirelandsown.net/fhughes.html. Site consultado em 15 de novembro de 2006, às 18: $29 \mathrm{hrs}$.
} 
ideologia deslocada, uma pessoa confinada entre grades e, finalmente, destruída. Enquanto o leitor pronuncia as palavras em voz alta, parece-nos que o fechamento dessas, juntamente com a rima sofrível que termina em consoantes fechadas e masculinas, faz com que a voz pareça algo morto enquanto vivo, e vivo enquanto morto. $\mathrm{O}$ som do ditongo final do último verso "-aim” abre a métrica para novas possibilidades, a favor das quais o próprio prisioneiro atesta em suas palavras finais. A longa estrofe de quatorze versos retorna novamente aos números da "via crucis", e a descrição de sua captura, igualmente, rememora a atitude de sacrifício e imolação - assim como a do dono da loja, de Tom e de Colum. Sendo assim, acoplado ao tom sacrificial do poema, há um toque de beatificação, pois Heaney tenta representar essas pessoas, mesmo com suas imperfeições e falhas, como verdadeiros santos que merecem serem recordados. Logo, o anacronismo presente na fala de "Francie" parece ser ainda aquele inspirado pela tragédia de "Cathleen ni Houlihan" de Yeats - daquele que renuncia à vida familiar e ao casamento para lutar pelo país:

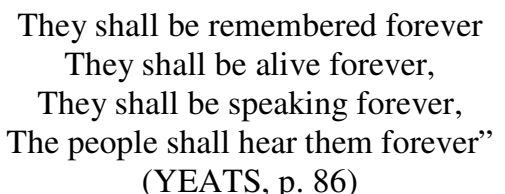

Sobre a discussão a respeito da representação social e histórica das vítimas das greves de fome na Irlanda do Norte, Edna Longley possui uma hipótese complementar à de Lloyd. Em suas palavras:

No seu poema 'Aisling', escrito próximo ao tempo dos grevistas de fome, Paul Muldoon pergunta se a Irlanda deveria ser simbolizada, ao invés da deusa abundante, pela doença anorexia: 'Seria ela Aurora, ou a deusa Flora,/ Artemidora, ou Vênus gloriosa,/ ou Anorexia que deixou/ uma mancha de limão no meu lençol de flanela?'. Ao culpar a emaciação dos grevistas da fome por sua causa política idealizada, o poema iguala a causa a uma forma de colapso psíquico. A 'Anorexia' é, portanto, Cathleen Ni Houlihan em uma fase terminal. Os anoréxicos buscam uma imagem própria irreal - em prática, um desejo de morte. De modo similar, o sonho nacionalista pode ter chegado a uma neurose destrutiva. (LONGLEY, 1994, p. 173) ${ }^{144}$

\footnotetext{
144 A crítica examina o colapso do nacionalismo em suas especificidades. Ela distingue Unionismo e Nacionalismo, à luz de suas diferenças constitutivas. Original: "In his poem 'Aisling', written near the time of the hunger strikes, Paul Muldoon asks whether Ireland should be symbolized, not by an abundant goddess, but by the disease anorexia: 'Was she Aurora, or goddess Flora,/ Artemidora, or Venus bright,/ or Anorexia, who left/ a lemon stain on my flannel sheet?'. In blaming the hunger striker's emaciation on their political
} 
Ao colocar no início do poema a voz do próprio "hunger striker", Heaney cria uma idealização atemporal do sujeito, que é logo desconstruída na segunda estrofe, ao passo que o autor, através da luta poética cede aos pentâmetros jâmbicos e não-jâmbicos. Ao emblematicamente ceder espaço a essa métrica, Heaney retrata sua funesta imagem de santo e mártir, transmutando-se na trufeira onde caiu sua primeira bomba e, por fim, na andorinha, como um provável símbolo para sua liberdade com a morte.

Com um início confuso de rimas oscilantes entre paralelas e intercaladas, a segunda estrofe apela para uma métrica incerta que se funde à própria falta de imagens para representar o leito de morte do prisioneiro. No que concerne à simbologia, há uma divisão tripartite que impera na estrutura das impressões do poeta sobre a morte de Francis Hughes - uma metáfora que se estende até ao dormitório, ou seja, ela é tão importante que ultrapassa o exterior - "and hunger died through the black dorm". Enquanto os símbolos pertencentes ao reino das plantas e parasitas (ferrugem, musgos e pinheiros) apontam em direção à deterioração, os relativos a animais (doninha) retratam a psique do morto e os que se referem à música, representam os conflitos sociais na Irlanda do Norte da época. Com isso, podemos compreender que a andorinha, por significar pureza e, ao mesmo tempo, realeza, cria uma noção dúbia da personalidade de Francis: ou ele seria ingênuo por abraçar um ideal heróico em um momento histórico em que não existe mais espaço para tal figura, ou então, ele teria sido absorvido pelo discurso da autoridade (a coroa britânica) que o deixa entregue a sua decisão de privar-se do alimento, tirando, assim, todos os seus ideais românticos. Essa assimilação é uma interpretação válida, pois acompanha a força da métrica decassílaba que se impõe a partir de sexto verso.

This voice from blight A

And hunger died through the black dorm: B There he was laid out with a drift of mass cards C At his shrouded feet. Then the firing party's D Volley in the yard. I saw woodworm B In the gate posts and door jambs, smelt mildew $\mathrm{E}$ From the byre loft where he watched and hit $\mathrm{F}$ From fields his draped coffin would raft through. G Unquiet soul, they should have buried you G In the bog where you threw your first grenade, $\mathrm{H}$

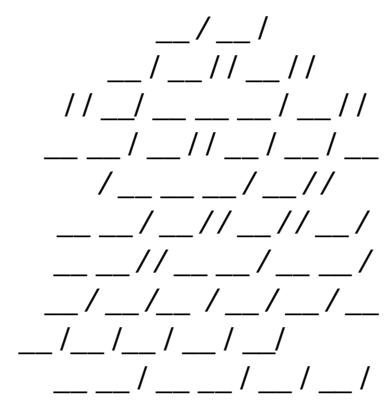

idealised cause, the poem equates that cause with a form of physical and psychic breakdown. 'Anorexia' is thus Cathleen Ni Houlihan in a terminal condition. Anorexic patients pursue an unreal self-image - in practice, a death wish. Similarly, the Irish nationalist dream may have declined into a destructive neurosis". (LONGLEY, 1994, p. 173) 
Where only helicopters, and curlews E

Make their maimed music and sphagnum moss I

Could teach you its medicinal repose $\mathrm{J}$

Until, when the weasel whistles on its tail K.

No other weasel will obey its call L

(O. G., p. 262)

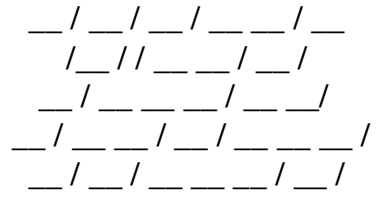

Somada à dificuldade de representar a morte de Hughes e o ativismo dos grevistas da fome, Heaney tenta, como Lloyd (1999, p. 63) afirma, ser o caso das representações cinematográficas sobre os "Troubles", além de encontrar novas formas de retratar os fatos de modo a evitar maniqueísmos e explicações tendenciosas. Assim, com essas escolhas frente ao corpo de Francis, Heaney problematiza ainda mais sua imagem ao inserir a música - tema que é visto em poemas como "The Given Note” (Door into the Dark, 1969) e "Serenades" (Wintering Out, 1972) - pois essa pode ser tanto destruidora, quanto curativa. Ambas as características parecem fazer com que o poeta tente expressar o fato de que o fantasma fora mutilado pela sociedade por razões políticas, mas também por ser ensurdecido pelas bombas. Em "Serenades" (ANNUNCIAÇÃO, 2004/ 2005) ele usa a metáfora da música dos confrontos armados para simbolizar a perda da racionalidade devido à guerra. O perdão, como característica curativa está associada ao cristianismo, à própria falta de perdão de Hughes, e aquele perdão do qual poeta sente falta, depois de ouvir acusações de seu primo. Mesmo desejando desculpar-se e ser redimido pela poesia Heaney não consegue concretizar ambas as instâncias, logo, resta então esperar tudo se consumir - "o apodrecimento e o fim" - para que ele compreenda o que fazer.

Desta forma, a continuação da idéia de escassez tem o seu ápice com a terceira estrofe em que, dentro do sonho mais uma vez, no mar e à deriva, o poeta se desculpa da vida conveniente que levara. Novamente, a imagem do mar o relembra do exílio como uma presença contínua que marca seu trabalho, ou seja, possibilitado por esse distanciamento, é que observa a violência, sem envolver-se com todos aqueles que morreram. Nesse sentido, há novamente a evocação literal ao surrealismo e a impossibilidade que esse demonstra. Na analogia da Irlanda do Norte, a guerra e as divisões sectárias podem apenas produzir uma liberdade na ausência, ou seja, dentro de si mesmo e na morte. Talvez seja esse o fato que o leva ao pessimismo. Como Benjamim (BENJAMIN, 1985, p. 34) ${ }^{145}$ ressalta, a mente

145 Artigo "O Surrealismo" em que Benjamin define este como a última vanguarda revolucionária. (BENJAMIN, 1985, p. 34) 
surrealista será de uma energia desconfiada e desiludida em que o potencial para a mudança social está fadado ao pessimismo, como visto na passagem:

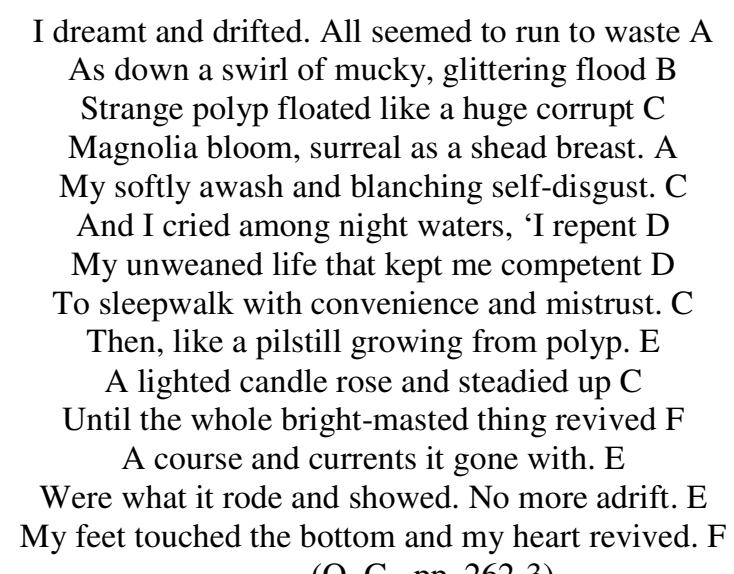$$
\text { (O. G., pp. 262-3) }
$$

Mesmo com a desesperança simbolizada pelas plantas estranhas desse mar em que Heaney se encontra, no décimo verso, dos quatorze da estrofe, surge um ponto firme: uma vela: "a lighted candle rose and steadied up". A métrica, no entanto, sugere que essa esperança não inspira confiança pois é colocada em pentâmetros jâmbicos perfeitos. Outra característica que aprisiona o poeta nessa atmosfera hostil do sonho e da não-liberdade é a rima invariável durante todo poema, como uma repetição monótona e contínua. Mesmo encapsulado na métrica, o poeta afirma não estar fora do rumo como antes e, dando vazão à força dessa imagem que se apresenta, seu coração morto retorna à vida. Mas por que isso acontece? Teria ele retornado à Irlanda? Estaria ele em algum lugar que reitera a sua esperança? Há a possibilidade de esperança? Caso haja essa possibilidade, no que ela seria fundada? Todas essas perguntas ressoam na mente de um leitor mais atento, principalmente porque ele chega em algum lugar após ter dado voz a esse grevista da fome do começo do poema.

Then something round and clear And mildly turbulent, like a bubble skin Or a moon in smoothly rippled lough water

Rose in a cobwebbed space: the molten Inside-sheen of an instrument

Revolved its polished convexes full Upon me, so close and brilliant I seemed to pitch back in a headlong fall. And then it was the clarity of walking

To sunlight and a bell and gushing taps In the next cubicle. Still there for the talking. 
The old brass trumpet with its valves and stops

I found once in a loft thatch, a mystery

I shied from then for I thought such trove beyond me.

(O. G., p. 263)

\section{A EPIFANIA DOS OBJETOS}

Como transcrevemos acima, a estrofe de número quatro, de uma forma quase que divina, Heaney descreve um trompete surgindo do meio do lago. A aparição do objeto é um tanto quanto enigmática, pois há uma corruptela das trombetas rumo à chegada do paraíso. O objeto diáfano que está ao alcance de suas mãos é um dos mais fortes dos metais e, na mente popular, materializado pelos sons desconcertantes, polifônicos, e acima de tudo, experimentais de Miles Davis. O movimento do poema é múltiplo, a identificação, complexa, e o sujeito poético começa a sair dessa determinação social das figuras de sua história e começa a reconhecer semelhanças dentro de diferenças. Os fluxos do sonho, das interpretações e associações são caóticos e rápidos, sugerindo que o seu ritmo deva ser aumentado. Talvez porque algo de novo urge a surgir, provavelmente esse sujeito, que não só usou o exílio para compreender sua terra, mas como a sua terra para compreender o lugar onde ele se afixou. A sua subjetividade poética é, portanto, uma localidade que, como um camaleão, disfarça-se de outras pessoas. Conseqüentemente, o distanciamento, como forma de conhecimento reflete a posição de que na diferença, nos clarões de consciência e nas pequenas cenas de presença na ausência, o autor reflete posições contrárias, com base na própria tradição cultural irlandesa, de modo a ponderar seu momento histórico de crises e indecisões perante seu futuro artístico.

Nesse sentido, ao fazer isso, o poeta entra no mecanismo que Maurice Harmon define sobre a poesia contemporânea do Norte da Irlanda:

se os poetas sentem-se atraídos pelo passado, é porque eles precisam de mais espaço do que a lírica oferece. A meditação histórica é uma forma de examinar o passado com a intenção de ver a direção presente e definir a própria situação... Porque a imaginação irlandesa retém e explora um sentido de mito e história, é compreensível que a memória e suas associações requeiram mais atenção... Kinsella e Heaney procuram unidade através do recurso de uma consciência observadora, um caminhante que evoca uma 
variedade de cenas, nas quais a figura de um peregrino é confrontada por uma sucessão de vozes. (HARMON, 2003, pp. 144-5) ${ }^{146}$

Logo, através da busca de uma intertextualidade cultural, ou até mesmo uma tradução cultural, nos termos de Homi Bhabha, que engloba a busca de paralelos entre culturas díspares, o poeta procura compreender uma nova forma de fazer poesia, que reflita as questões interculturais e não se feche para reescrever a história daqueles que foram vencidos nos distintos processos históricos.

Se penetrarmos um pouco mais profundamente no significado dessa abertura de espaços para uma cultura distinta, podemos compreender que Heaney procura novas formas de solidariedade para resolver o seu confronto interno. De acordo com Homi Bhabha, a única possibilidade de se produzir uma cultura que articule a diferença é anulando a soberania do "eu", de modo a atingir uma política que não anule as diferenças culturais. Nesse sentido, esse "eu" que é definido pela cultura irlandesa e inglesa - o subalterno, a herança cultural - é transmutado em algo que resulta de uma teia intercultural. Nas palavras de Bhabha:

a fragmentação de identidade é freqüentemente proclamada como uma pura espécie de liberalismo anárquico, ou de voluntarismo, mas prefiro enxergá-la como o reconhecimento da importância da alienação de $e u$ na construção das formas de solidariedade. (BHABHA, 1990, p. 213) ${ }^{147}$.

Embora ainda não completamente inserido em uma outra cultura, o poeta tenta compreender as tradições e a maneira de enxergar o mundo vista nos olhos dessas tribos indígenas. Não só as tribos são colocadas em questão, mas também a música americana,

\footnotetext{
${ }^{146}$ Maurice Harmon define uma linha mais histórica e abrangente para lírica após da publicação de North (1975) de Seamus Heaney. Original: If poets feel drawn to the past, they tend to feel the need for more space than is provided by the lyric. Historical meditation is a way of examining the past in order to see the present directions and to define one's own situation... Since the Irish imagination retains and exploits a sense of myth and history, it is understandable that memory and its associations require more scope... Kinsella and Heaney seek unity through the device of an observing consciousness, a single walker who conjures up a variety of scenes or a central pilgrim-figure who is confronted by a succession of voices. (HARMON, 2003, pp. 144-5)

${ }^{147} \mathrm{O}$ autor define o conceito de diferença cultural a partir da visão de um sujeito discursivo, inserido no processo de tradução cultural e hibridismo. Para ele, a grande questão Pós-Moderna é encontrar uma agência social na fragmentação identitária, pois essa não deve ser vista como uma celebração, mas como meio de se criar novas formas de solidariedade e negociação política. Original: "The fragmentation of identity is often celebrated as a kind of pure anarchic liberalism or voluntarism, but I prefer to see it as recognition of the importance of the alienation of the self in the construction of forms of solidarity". (BHABHA, 1990, 213)
} 
como o jazz, que faz muito o uso do trompete. Esse significaria uma visão curativa e prazerosa do presente doloroso.

Se por um lado o sujeito poético aceita tal visão, ele a considera um mistério além de seu alcance. Essa aceitação misturada com uma recusa seja talvez porque o poeta ainda continue aprisionado em sua própria cultura e não consiga fluidez suficiente para entrar nesse rápido movimento, ou então porque sua culpa continue a atormentá-lo. Novamente ele reproduz o mecanismo de história segundo Santo Agostinho. Se por um lado ele está nesse presente tentando recuperar o passado das tribos pré-colonizadas, a sua linguagem não consegue recapturar tais fatos como eles foram, pois se trata de um sonho, algo além da própria razão. O mistério estaria em sua própria vontade de transcender a sua história através da evocação de objetos religiosos que pertencem a outras culturas. Ademais, a mistura dos sons provindos do sino da igreja, faz com que a sua descoberta seja ainda mais reveladora. Há todo um clima enigmático sendo criado, visto que o seu achado, apesar de ocasionar um novo ritmo ao poema - os versos se tornam mais curtos e dinâmicos - por outro lado, castra-o, principalmente porque não é apresentada uma explicação para essa imagem. Entretanto, ele a faz na última estrofe.

A constante repetição da afirmação do quanto o sujeito poético odeia seu lugar de origem e as suas circunstâncias históricas que o transformaram, é contrastado com a liberdade das tribos que dançam até a chegada do cervo. Outro fato a acrescentar é que o trompete da estrofe anterior parece ter saído de uma teia que, na descrição do poeta, é extremamente semelhante aos filtros dos sonhos dos índios Lakotas norte-americanos. Todas essas imagens apontam para o outro lado do Oceano e fazem com que o leitor compreenda que, possivelmente, o poeta estaria descobrindo sua Irlanda do Norte através do olhar daquele outro, que muitas vezes, por possuir culturas e identidades tão estranhas e diferentes, são semelhantes: ambos possuem movimentos históricos de desapropriação e guerra: os vencidos. Dessa maneira, o estranho do ponto de vista o faz sair da cápsula histórica do norte e observar outros pontos norteadores para a sua poesia. O fim da sua peregrinação já está próximo e aqui são apresentadas as primeiras sementes de uma libertação definitiva. Toda visão histórica e social do poema aparece sob essa nova luz do trompete que surge do sonho, e o sonho, que provém dos índios Lakotas, e desses, a dança subseqüente. 
O desejo por esse ritual reflete a busca pela tranqüilidade e equilíbrio, pois esse animal é símbolo da paz, gentileza e sensibilidade para os Lakotas. A imagem no espelho é o duplo, o outro com o qual o poeta tenta encontrar um intercâmbio de idéias e conceitos. Entretanto, há um senso de estranho aqui - "uncanny" - no sentido que Freud confere ao termo, algo que, por ser totalmente diferente, pode ser usado como instrumento de conhecimento e descoberta. Segundo Joy Harjo, poeta norte americana da tribo Muscogee, a "deer dance" pode estar associada ao livre impulso sexual, ao nascimento de uma nova geração e à própria cristandade, visto que há relatos em que a "Ghost Dance" feita pelas tribos que inseriam os ritos da religião católica nas tradições religiosas ameríndias (HARJO, 2000, p. 216). ${ }^{148} \mathrm{O}$ relato mais famoso é descrito no livro Bury my heart at Wounded Knee (2001), em que Dee Brown descreve como o chefe Kicking Bear introduz a dança do Messias nas tribos de Sitting Bull, e cujos reflexos chegam ao maior massacre indígena da história americana - a batalha de Wounded Knee, em que não foram poupadas nem mulheres e crianças.

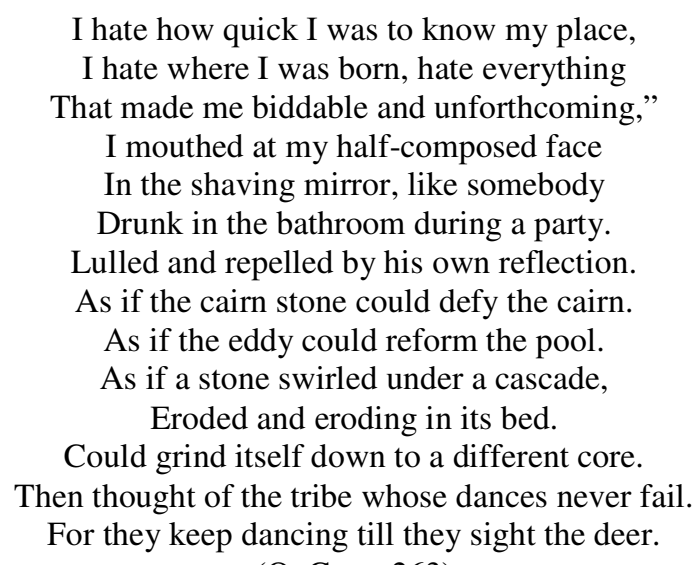$$
\text { (O. G., p. 263) }
$$

De uma maneira questionadora, o poeta começa com as recusas em pentâmetros jâmbicos, fazendo com que o leitor perceba que essa característica é algo imposto através de estereótipos que foram construídos na formação de sua identidade colonial irlandesa. Portanto, ele não odeia a sua própria cultura, mas ele odeia o modo como essa foi subjugada pelos outros - provavelmente como os chefes indígenas sofriam ao serem confinados em reservas, uma vez que foram expatriados dentro de sua própria terra. Toda

\footnotetext{
${ }^{148}$ A "Dança do Cervo" sempre acontece com a aparição da Mulher Búfalo, cuja presença pode inspirar desejos sexuais e harmonia. (HARJO, 2000, p. 216).
} 
essa complexa teia de identificações intrica a relação que Heaney tem com a sua cultura, pois é como se através do sonho, do misterioso e das danças e músicas desconhecidas, ele pudesse atingir um patamar mais elevado a partir da sua própria relação com o exílio. Sendo assim, na continuação do poema, ele se volta para a importância dos objetos, e como estes podem construir seu espaço de identificações. Toda a significação das estrofes divididas em quatorze versos faz com que o poeta compreenda a questão da exclusão e exploração. Mesmo sendo algoz, Hughes foi acima de tudo vítima e, ao dar voz àqueles com quem se identifica, Heaney procura conferir um caráter até mesmo messiânico para sua poesia, como sendo aquela que valoriza os desprezados. Porém, mesmo assim, é necessário que ele entenda qual o seu alcance no que está por vir.

De acordo com Corcoran a seção X:

apresenta um outro fantasma inanimado, uma xícara - ou taça - retirada da casa em que Heaney passou a infância para ser usada em uma peça, e devolvida como o Saltério de Renan que foi miraculosamente retirado do lago por uma lontra no início de Sweeney Astray - um símbolo para as inesperadas traduções do conhecido e do doméstico. (CORCORAN, 1986, p. 162) $)^{149}$

Mais do que uma tradução do conhecido e do doméstico, essa presentificação de um simples objeto que fora transmutado em algo mágico devido ao toque da arte - no caso a performance teatral - representa uma nova articulação dessa lírica. Por outro lado, essa arte, que como a taça devolvida ao poeta, pode também ecoar diversas estórias: as mais imediatas conexões são com o rei Sweeney, o Santo Gral de Jesus, as Cruzadas Arturianas para sua recuperação e a origem celta do cálice da fartura. A imagem desse objeto, que de tão simples e doméstico, é transformado em algo excepcional é, portanto, uma metáfora da sua própria arte que, por trazer diversas estórias (e até com pretensões de trazer outras além do seu conhecido), reescreve o passado literário e histórico em uma nova égide e significação.

Deste modo, vemos duas direções na renovação da lírica de Seamus Heaney: se há um desejo rumo ao inesperado e diferente, como a tradição ameríndia das danças, há

\footnotetext{
${ }^{149}$ Continuação da argumentação de Corcoran sobre o poema "Station Island”. Original: "X has another inanimate ghost, a drinking mug removed from Heaney's childhood home by actors for use in a play, and returned as Ronan's psalter is miraculously returned from the lake by an otter at the opening of Sweeney Astray - a further symbol for the unexpected translations the known, ordinary and domestic may undergo". (Corcoran, 1986, p. 162)
} 
também um retorno ao basal de sua cultura. Logo, as próximas duas últimas estações resolverão de uma maneira bastante reveladora as contradições que essas categorias enfrentam quando contrastadas com o debate político e histórico que esteve presente nas estações até o momento. Contudo, foquemos nossa atenção na forma pela qual é apresentado esse objeto familiar, lendário e estranho. Ao invés das grandes estrofes como as que o poeta estava compondo desde a parte V, com exceção da VII, temos aqui um retorno ao quarteto simples com rimas paralelas consonantes. Há uma diminuição nos pés poéticos - o abandono do pentâmetro pelo octossílabo - e uma tentativa bem ritmada de tornar a seção um pouco mais serena, semelhante a uma pequena canção, visto que as seis breves estrofes também recuperam essa idéia do canto curto e de fácil memorização. Nessa transição do racional para uma métrica quase que medieval, o poeta faz um percurso de retorno às raízes mais primitivas de sua poesia, o que, paradoxalmente, também o leva para algo de moderno e inovador na intertextualidade com a técnica de James Joyce.

Se por um lado ele retoma estórias medievais de Sweeney, toda a lógica de associações desenvolvida por essa parte segue os fluxos de pensamento propostos por Joyce. Ademais, o poeta ainda procura preservar a essência religiosa da epifania, visto que na última estrofe, o leitor é lançado do mítico e da fantasia para a luminosidade do religioso. A porta de luminosidade, que é apresentada no último verso da última estrofe define precisamente o preceito artístico com o qual o poeta deseja prosseguir: o desejo de um misticismo atemporal, combinado com a escrita revolucionária e cética do romancista. A estrutura observada é de duas primeiras estrofes que colocam o poeta não na peregrinação, mas na hospedaria, ou seja, longe do clima de orações, onde ele pode observar um cálice parecido com o da sua juventude. Duas estrofes posteriores que o levam de volta ao objeto de infância e o remetem novamente à peça na qual fora utilizado quando um casal celebra o seu amor com ele nas mãos, e outras duas totalmente fora do clima real e prosaico cujo conteúdo o impulsiona ao mito de Sweeney e à revelação artística. Embora sendo prosaicas, as cenas do passado e do casal não deixam de ser referências literárias, pois se em um podemos observar a descoberta da arte de um jovem homem - A Portrait of the Artist as a Young Man - podemos também ver a descoberta do amor através de um cálice em lendas medievais - a tradição celta do Loving Cup. Portanto, a técnica de observar a xícara é retirada das teorias de James Joyce sobre a epifania. 
Na primeira versão do Retrato do Artista Quando Jovem, James Joyce insere um comentário extremamente revelador sobre o seu conceito de epifania. Ao observar uma mulher na escadaria da sua casa, acompanhada por um homem que era alvo de seus insultos, o artista do título compreende o significado da paralisia irlandesa. Como Raymond Williams explica sobre a técnica do escritor:

essa trivialidade o fez pensar em coletar muitos momentos em um livro de epifanias. Por epifania, ele designava uma manifestação espiritual, quer na vulgaridade da palavra ou do gesto, quer na frase memorável da mente por si mesma. Ele acreditava que cabia ao homem das letras a tarefa de registrar essas epifanias com um cuidado extremo, observando que elas próprias representam os mais delicados e evanescentes momentos. (WILLIAMS, 1986, p. 106) $)^{150}$

Sendo assim, essa poderia ser extraída de diversas circunstâncias, no caso exemplar para Stephen Dedalus, o relógio de Ballast Office. Segundo a sua teoria, pautada na arte estética de Tomás de Aquino:

primeiro reconhecemos que o objeto é uma coisa única e integral, depois descobrimos que é uma estrutura organizada e composta, uma coisa, de fato: finalmente, quando em relação com suas partes internas é extraordinário, quando as partes são ajustadas a um ponto especial, nós descobrimos o que é aquela coisa. A alma do objeto mais comum, a estrutura pela qual ele é ajustado nos parece radiante. O objeto atinge sua epifania (JOYCE, 2006) ${ }^{151}$

No caso de Heaney o cálice, não tanto como um objeto extraordinário mas pelas memórias que recobra, atinge sua epifania no momento em que é associado à descoberta da arte - e todo o estranhamento que tal relação traz consigo mesma.

Morning stiff in the hostel. A pot.

hooked on forged links. Soot flakes. Plumping water.

\footnotetext{
${ }^{150}$ Original: this triviality made him think of collecting many such moments together in a book of epiphanies. By epiphany he meant a sudden spiritual manifestation, whether in the vulgarity of speech or gesture, or in a memorable phrase of the mind itself. He believed that it was for the man of letters to record these epiphanies with extreme care, seeing that the themselves are the most delicate and evanescent of moments. (WILLIAMS, 1986, p. 106)

${ }^{151}$ Continuação do livro Stephen Hero. Original: "First we recognise that the object is one integral thing, then we recognise that it is an organised composite structure, a thing in fact: finally, when the relation of the parts is exquisite, when the parts are adjusted to the special point, we recognise that it is that thing which it is. Its soul, its whatness, leaps to us from the vestment of its appearance. The soul of the commonest object, the structure of which is so adjusted, seems to us radiant. The object achieves its epiphany". (Joyce, James. In. http://theliterarylink.com/joyce.html. Consultado em 26 de novembro de 2006, às 9h00)
} 
The open door brilliant with sunlight.

Hearth smoke rambling and a thud of earthenware

drumming me back until I saw the mug beyond my reach on its high shelf, the one patterned with blue cornflowers, sprig after sprig repeating round it, as quiet as a milestone...

When had it not been there? There was one night when fit-up actors used it for a prop and I sat in the dark hall estranged from it as a couple vowed and called it their loving cup (O. G., p. 265-6)

Enquanto observa a peça que provavelmente retoma a tradição do The Loving Cup celta, em que o casal, quando recém casado, faz juras de amor perante o cálice sagrado e o mantém por toda vida, passando de geração em geração, dúvidas surgem na mente artística. Esse cálice de fartura e de bonança pode ser contrastado com aquele símbolo do império inglês que, pelas cruzadas e pela tentativa de recuperar aquele com o qual Jesus celebra a última ceia, acaba perpetuando uma linha de sofrimento - como fora visto nos poemas prévios a esse. A preferência do poeta pela tradição celta e pela inserção da mesma no poema - após várias sessões em que se culpava por não conseguir abarcar o social em sua lírica - é significativa, pois ele pretende encontrar uma ligação com a tradição irlandesa, não através de elementos mágicos, mas, novamente por meio da solidariedade e da esperança. Esse sentimento seria algo humano e não tão sobrenatural: o amor. Para Heaney na poesia irlandesa primitiva:

há o pagus, a selva pagã, verde, com uma garganta poderosa, desimpedida; por outro lado há... a disciplina cristã, o sentido de um princípio espiritual e um chamado religioso que transcende toda a exuberância da natureza. $\mathrm{O}$ escritor é como um escriba, e dentro dessa tradição ermitã da igreja irlandesa que a primitiva poesia da natureza irlandesa se desenvolve. (HEANEY, 1980, p. 183) ${ }^{152}$

Nesse exato momento, Heaney funde essa característica dupla na sua poesia de modo a penetrar em algo ainda mais profundo de suas origens, o exílio torna-se, assim, um

\footnotetext{
${ }^{152}$ Heaney explora a tradição celta na tradição poética irlandesa, identificando-se abertamente com a mesma. Original:" there is the pagus, the pagan wilderness, green, full-throated, unrestrained; on the other hand there is... the Christian disciplina, the sense of a spiritual principle and a religious calling that transcends the almost carnal lushness of nature itself. The writer is as much hermit as scribe, and it is within this anchorite tradition of the early Irish church that the early Irish nature poetry develops". (HEANEY, 1980, p. 183)
} 
retorno enviesado. Como ele próprio explica a origem desse objeto em um de seus artigos a respeito do teatro irlandês:

Minha própria imagem dessa transformação é uma pesada xícara de barro
que ficava na prateleira de nossa cômoda em Mossbawn e agora está em uma
estante de livros em Dublin. Em torno da segunda metade de 1940, a xícara
foi emprestada para o grupo The Sparks e foi usado como cenário de uma de
suas peças. Acredito que era a história de Noreen Brown, pois me recordo de
estar sentado, tarde da noite, no Tin Hut e vendo ela ser levantada em um
brinde de despedida por um cavalheiro, em direção à sua donzela chorosa
que seguiria em direção à sua fatal viagem rumo à América. Anos depois,
quando estava escrevendo a continuação de Station Island, eu precisava de
algo para representar a realidade da 'palavra mágica encantatória', algo que
consumisse o comum e o arraigado em duvidoso, no 'deslumbramento da
impossibilidade', algo que significasse possibilidade, um alcance maior.
(HEANEY, 2005, p. 5) ${ }^{153}$

Desta maneira, como podemos perceber por meio das palavras do poeta, o objeto doméstico torna-se estranho e atraente por estar inserido em outro contexto. Sendo assim, no momento em que as cortinas do teatro são fechadas e a primeira epifania do objeto é concluída, observamos que outra toma forma. Revestida de traços mnemônicos que remetem à memória involuntária de Proust, a primeira parte de Sweeney Astray, denominada em irlandês de Buile Suibhne, é evocada. Insistimos no caráter simbólico dessa imagem principalmente porque o sujeito poético já está recordando uma outra reminiscência do passado, ou uma epifania pueril, em que, como uma criança, associa a taça ao livro de salmos trazidos de volta ao rei Ronan, quando Sweeney o atira ao lago. Essa multiplicidade de características que o objeto está adquirindo varia proporcionalmente de acordo a arte do poeta, pois essa está tentando encontrar novas formas de identificação. É como se o poeta estivesse recusando uma conexão imediata com o presente, e criando,

\footnotetext{
${ }^{153}$ Artigo em que Heaney explora as possibilidades do teatro irlandês ser representado fora de seu lugar de concepção. Original: "My own image for this transformation is a heavy crockery mug that once stood in the shelf of our dresser in Mossbawn and now stands on a bookshelf in Dublin. Some time in the mid-to-late 1940, it was borrowed by The Sparks and used as a pro in one of their plays. I think it was the story of Noreen Brown, because I remember sitting later that night in the Tin Hut and seeing it raised in a farewell toast by a lover to a weeping maiden who was departing on her fatal voyage to America. Years later when I was writing the sequel called Station Island I needed something to represent the reality of the 'magic, enchantment, spell', something that consumed the ordinary and the ingrained and the dutiful in the 'dazzle of the impossible', something signifying possibility, a farther range". (HEANEY, 2005, p. 5)
} 
através da busca de um passado e estórias atemporais, um novo sentido para sua arte. Com isso, Sweeney torna-se o alter-ego do poeta, como ele argumenta:

minha relação fundamental com Sweeney, no entanto, é topográfica. Seu reino está no que é a parte sul de County Antrim e ao norte de County Down, e por mais de trinta anos eu morei à beira desse território, à vista de alguns lugares de Sweeney e ao alcance da voz de outros... de uma forma ou de outra, ele parece ter estado comigo desde o princípio (HEANEY, 1986, p. iv) 154

Com um paralelo bem definido, o autor voltará mais uma vez para pré-história.

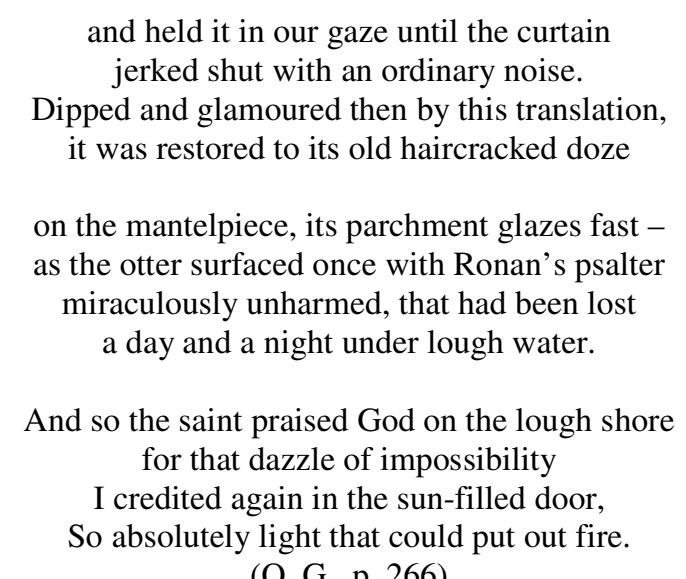$$
\text { (O. G., p. 266) }
$$

Ao comparar o cálice à taça de sua casa, Heaney aproxima-se de Sweeney, pois o poeta também teve uma atitude negativa. Assim como o rei jogou fora o livro dos salmos e fora punido a viver como um pássaro, Heaney também o foi ao se afastar da Irlanda e tentar escrever sobre as pessoas que continuaram a ser atormentadas pela guerra. Portanto, a recordação não é somente da história de Sweeney, mas igualmente da batalha de Moira, em que o rei é punido. Nesse sentido, o poeta chama novamente a atenção do leitor para a marca da violência e não da harmonia e paz, constatando que, mesmo nas estórias aprendidas durante a infância, o poeta observa a marca da agressividade sendo impressa. Com isso um outro desejo se forma: o da utópica harmonia pacífica. Ainda sobre Sweeney, o poeta afirma:

\footnotetext{
154 Prefácio do livro Sweeney Astray. Original: "My fundamental relation with Sweeney, however, is topographical. His kingdom lay in what is now South County Antrim and North County Down, and for over thirty years I lived on the verges of that territory, in sight of some of Sweeney's places and in earshot of others... one way or another, he seemed to have been with me from the start". (HEANEY, 1986, p. iv)
} 
evidências de fontes literárias e históricas o (J. G. O’Keeffe) levaram a concluir que Buile Subhine é o desenvolvimento de tradições que datam da batalha de Moira (637 d.C.), a batalha em que Sweeney ficou louco e, no cumprimento da maldição de São Ronan, foi transformado em um pássaro do ar. O que temos então, é uma criação literária; diferente de Finn McCool ou Cuchulain, Sweeney não é uma figura dada de um mito ou lenda, mas uma personagem situada historicamente, embora a questão de que ele seja ou não baseado em um rei histórico chamado Sweeney ainda permanece aberta (HEANEY, 1986, p. i) $)^{155}$

Tal explicação de cunho histórico, faz com que compreendamos o quanto o poeta, mesmo retornando a um passado remoto, ainda continua fixado na história irlandesa, tentando compreender como essa atinge sua lírica e a transforma.

Quando após a recuperação milagrosa dos salmos pela lontra, símbolo celta da amizade, pois ela ajudava os viajantes a encontrar tesouros escondidos e talentos valiosos, e também a ganhar sabedoria (Cf. irelandsown.net/otter.html, 2006), o poeta recebe a epifania final. Entretanto essa, de uma maneira muito obscura, não fica clara para o leitor. Apenas o poeta - que resolverá esse enigma nas próximas últimas seções - parece saber o significado dessa porta que, de tão iluminada, pode apagar o fogo. De qual fogo estaria ele falando? Daquele que é observado nas batalhas? Ou daquele que ainda permanece no coração dos homens, como aquele que impulsionou Ronan a condenar Sweeney, e aquele que o fez enlouquecer? Todas essas perguntas produzem uma relação desordenada, visto que o poeta se apóia na força reveladora da epifania. Essa, por sua vez, muda o ciclo dos objetos, e leva o poeta a uma revelação sobre si próprio. Assim, tal descoberta não será apenas revertida em conhecimento sobre si mesmo, mas sobre todo o seu percurso artístico, fazendo com que ele reveja sua trajetória. Logo, a epifania é completa, pois além de fazê-lo rever toda uma tradição, essa ainda o faz mudar de direção.

Ainda sobre a tradição celta, o poeta continua em seu artigo:

quando pensamos sobre os tabus a atmosfera de medo e a aflição das fadas que cerca o interior até os dias de hoje e as peregrinações que ainda ocorrem

\footnotetext{
${ }^{155}$ Continuação do prefácio a edição de Sweeney Astray. J. G. O’Keeffe é autor da primeira tradução de Buile Suibhine na qual Heaney se baseia. Origina: "Evidence from literary and historical sources leads him (J. G. O'Keeffe) to conclude that Buile Subhine which we now posses is a development of traditions dating back to the time of the Battle of Moira (A.D. 637), the battle where Sweeney went mad and was transformed, in fulfillment of St. Ronan's curse, into a bird of the air./ What we have then, is a literary creation; unlike Finn McCool or Cuchulain, Sweeney is not a given figure of myth or legend but an historically situated character, although the question of whether he is based upon an historical king called Sweeney has to remain open"
} 
em lugares pertos dos poços sagrados... quero sugerir que essa poesia primitiva é sustentada por uma afiliação inconsciente profunda aos mistérios da floresta, mesmo aparentemente proclamando sua fidelidade à nova religião. (HEANEY, 1980, p. 186) ${ }^{156}$

Absorvido com a questão metafísica e as características sobrenaturais da Irlanda primitiva, o poeta, na seção seguinte, procura alinhar suas posições pessoais com as da peregrinação que faz. Entretanto, ao invés de fazê-lo de forma subserviente, o poeta faz uma leitura enviesada da tradição mística do poeta espanhol Juan de la Cruz, que foi torturado e morto por tentar introduzir, juntamente com Teresa d'Ávila, mudanças na ordem religiosa vigente na baixa Idade Média. De modo a apropriar-se da tradição do espanhol, o poeta faz uma versão do poema "Cantar Del alma que se huelga de conoscer a Dios por fe" introduzindo alguns versos ao original.

\section{A METAFÍSICA: O RECONHECIMENTO DO MisTICISMO IRLANDÊS ATRAVÉS DE JUAN DE LA CRUZ}

Embora Heaney pareça estar ingressando na esfera do sobrenatural com as iluminações das epifanias, é revelador o fato de ele fazê-lo a partir do poeta medieval Juan de La Cruz. Menos devido a sua característica desafiadora e mais em razão de sua visão espiritual, o poeta escolhe a poesia do carmelita espanhol porque pretende, nessa parte do poema, demonstrar um desejo de reconstruir a exterioridade a partir da interioridade De acordo com Seyyed Hossein Nasr (NASR, 1989, p. 34) "o projeto do místico é reverter o processo normal em que a sensação é alimentada por imagens exteriores. Ele deseja esvaziar os sentidos de todas as sensações que vêm de fora, incluindo a memória da sensação e sensibilizar o corpo a partir do interior". ${ }^{157}$ Nessa égide, compreendemos que Heaney não quer se afastar da religião, muito provavelmente porque procura retornar às práticas religiosas de uma Irlanda primitiva e, pautada nessas, reconstruir sua identidade.

\footnotetext{
156 Original: "When we think of all the taboos and awe surrounding the fairy thorn in the Irish countryside until very recently, and of the pilgrimages which still go on in places to the ancient holy wells... I want to suggest that this early poetry is sustained by a deep unconscious affiliation to the old mysteries of the grove, even while ardently proclaiming its fidelity to the new religion". (HEANEY, 1980, p. 186)

${ }^{157}$ Original: "the project of the mystic is to reverse the normal process in which sensation is fed by external images. He wishes to empty the senses of all sensation coming to them from the outside, including the memory of sensation, and sensitize the body only from the inside." (NASR, 1989, p. 34)
} 
Nessas conexões múltiplas, o poeta recupera a lírica de uma subjetividade que se perdeu em meio à culpa e às acusações. A medida que chegamos ao final do poema, mais questões surgem sobre a origem dessa nova lírica, pois se por um lado ela deseja não ser mais culpada e retratar de maneira tão imediata a história, ela continua sendo atraída para a história de violência da qual faz parte. Portanto, mesmo havendo uma transformação, o poeta não consegue se desvencilhar completamente dessa tradição.

Na parte XI do poema há uma criação bastante curiosa, uma vez que Heaney insere na metade do poema a tradução de "Cantar del alma que se huelga de conoscer a Dios por fe" e, com base nessa, desenvolve mais quatro estrofes. De acordo com Corcoran:

em XI o fantasma é o monge com quem Heaney fez sua confissão e o qual, sugerindo que ele 'lesse poemas como preces', pede como penitência, para que ele o traduza algo de São João da Cruz, místico espanhol do século XVI. Heaney responde tardiamente com a sua versão da 'Canção da alma que se alegra em conhecer a Deus pela fé', um hino à fonte da trindade que deve ser descoberta dentro do sacramento da Eucaristia, como sinal da crença na fé em uma comunidade harmoniosa. (CORCORAN, 1986, p. 163) ${ }^{158}$

Em uma leitura mais atenta do poema, podemos compreender que o poeta não é obediente a essa expiação, pois a tradução, além de ser tardia, não se dá completamente, visto que ele troca a ordem das estrofes cinco e seis originais e introduz um terceiro elemento, que ao invés da luminosidade da primeira, oculta o pão da vida. Com frutíferas imagens religiosas, o poeta tenta escapar da escuridão dos pântanos que dominaram a sua lírica durante o começo da carreira, mas no decorrer do poema, entendemos que essa luminosidade nunca será completa.

\footnotetext{
As if the prisms of the kaleidoscope I plunged once in a butt of muddied water Surfaced like a marvelous lightship and out of silted crystals a monk's face that had spoken years ago from behind the grille spoke again about the need and chance
}

\footnotetext{
${ }^{158}$ Continuação da argumentação de Corcoran sobre o poema "Station Island". Original: "In XI the ghost is a monk whom Heaney once made his confession and who, suggesting that Heaney should 'Read poems like prayers', asked him to translate something by St. John of the Cross, the sixteenth century Spanish mystic, as a penance. Heaney responds now, belatedly, with his version of 'Cantar del Alma que se huelga de conoscer a Dios por fe', the 'Song of the soul that is glad to know God by faith', a hymn to the 'fountain' of the Trinity to be discovered within the sacrament of the Eucharist, that sign of the believing Church in harmonious community". (CORCORAN, 1986, p. 163)
} 
to salvage everything, to re-envisage

the zenith and glimpsed jewels of any gift mistakenly abased...

\author{
What come to nothing could always be replenished. \\ 'Read poems as prayers', he said, 'and for your penance \\ translate me something from Juan de la Cruz'. \\ Returned from Spain to our chapped wilderness, \\ his consonants aspirate, his forehead shining, \\ he had made me feel there was nothing to confess.
} (O. G., p. 264, 265)

Acreditamos que é essa a razão pela qual o poeta na primeira estrofe demonstra que essa visão provém dos prismas coloridos do caleidoscópio que ele havia deixado em uma água barrenta. As seqüências de rimas um tanto quanto fluídas e óbvias demonstram essa vontade de seguir um esquema claro que não surpreenda com conexões mais complexas provindas da língua irlandesa. Contudo, no momento em que a voz do passado surge, disfarçada de sua própria voz, já que o poeta tem a vontade de traduzir tal peça lírica, há uma desestabilização nos tercetos paralelos, e o poeta começa com uma versão praticamente literal de Juan de La Cruz. Nessa versão literal da obra, o poeta já insere um elemento da diferença, que é a dificuldade em lidar com as consoantes aspiradas do espanhol. Seria interessante observar que, ao invés de evocar artistas como Goya e Lorca, como ele fizera anteriormente, aqui o autor direciona seu olhar para a visão religiosa da Espanha, ou seja, as tensões históricas que o atormentaram em "Summer 1969" (North, 1975) parecem se calar para que possa deixar a sua alma ser preenchida pela água dessa fonte.

\footnotetext{
Now his sandaled passage stirred me on to this: How well I know that fountain, filling, running Although it is the night.

The eternal fountain, hidden away,

I know its heaven and its secrecy although it is the night.

But it is not source because it does not have one, which is all sources' source and origin although it is the night.

No other thing can be so beautiful.

Here the earth and heaven drink their fill although its is the night.

So pellucid it never can be muddied,
} 


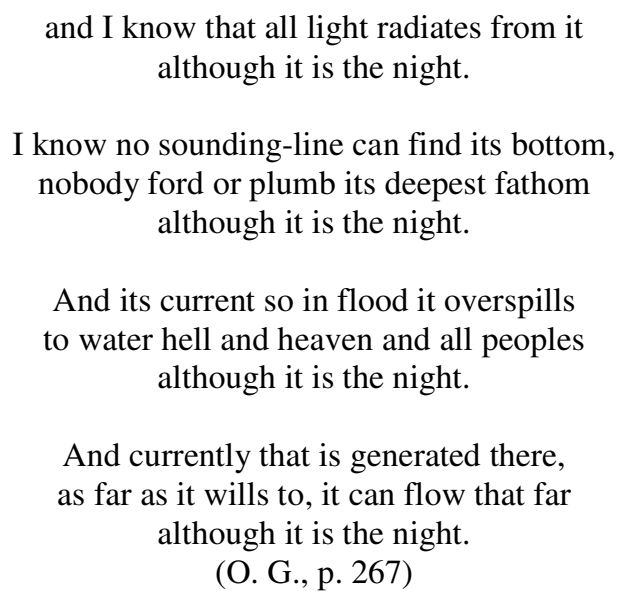

Como observado nas estrofes citadas acima, o autor dá continuidade à transformação ocorrida desde a parte IX. Desta maneira, Heaney desenvolve a idéia de que conhece a natureza oculta da fonte: sua origem, qualidade e correntezas. O dado inovador está no fato dela, mesmo sombria e barrenta, produzir um pão da vida. Esse jogo de claridade e escuridão é uma constante na poesia do autor desde Door into the Dark (1969), e chegando ao ponto máximo com Seeing Things (1991), em que há uma busca quase que obsessiva pela luminosidade. Dentro dessa temática que se desenvolve durante os seus livros, Heaney esboça um percurso também: se no livro de 1969 ele ainda desejava sair de uma Irlanda do Norte cuja paisagem geográfica o oprimia devido às guerras, no de 1991, ele compreende o quanto sempre esteve exilado de sua terra natal. Portanto, podemos entender esse poema como um preâmbulo em que o poeta tenta expurgar a sua culpa de ter dado as costas para a terra, e que, através da luminosidade, tenta recuperar o que perdeu em um retorno deslocado. Contudo, essa recuperação é praticamente impossível, fazendo com que todas as suas tentativas posteriores tornem-se frustradas.

No poema "Bogland" (Door into the Dark, 1969) o leitor encontra Heaney refletindo sobre a sua imagem em frente a um poço escuro. As reflexões que surgem a partir da impossibilidade de visão se fecham na presença do próprio pântano, posto que frente a um campo aberto, ele não consegue enxergar além da escuridão da água escura e barrenta. A partir dessas imagens, o poeta pensa sobre as múltiplas camadas que estão presentes na história irlandesa, as quais, como o sol, não podem ser fatiadas ou compreendidas separadamente. Ao ser contrastado com a seção XI de "Station Island", compreendemos que o autor deseja sair dessa imagem de destruição e impossibilidade, 
visto que naquele, ele retoma a imagem do alce retirado do pântano, ou seja, de uma morte revista pelos olhos da impotência e de um centro molhado e enlameado. Esse centro é precisamente a ligação entre "Bogland" e o presente poema, principalmente porque ele consegue retirar algo dessa água turva. Porém, de tão bem construído, o poema gira em torno dessa noite, e chega precisamente na origem da fonte: o pão que, como na religião cristã, dará origem a uma nova vida.

Se por um lado o pão vivo é aquele que salva os homens por seu sacrifício na pessoa de Jesus Cristo, por outro ele é a própria essência do sacrifício e morte cristã. Assim, o poeta, invés da claridade de visão e da plenitude religiosa que ele poderia sentir por ser alimentado, lamenta pela fonte escura da qual se alimenta. Logo, podemos compreender essa representação tão dúbia da fonte como a própria história irlandesa, que assim como em "Bogland" não pode ser cortada, e da qual se origina de um centro molhado - uma fonte escura de guerras e sofrimento. Portanto, esse poema tem uma ligação profunda com a morte do dono da venda, do arqueólogo, e, principalmente, de Francis Hughes, o grevista da fome. $\mathrm{O}$ dado mais revelador é o contraste entre fome e fartura, principalmente porque a primeira é uma constante na história irlandesa. O primeiro dado da fome se dá no século XIX, quando devido a um fungo nas plantações de batatas designadas à metrópole irlandesa, um terço da população morre de fome, enquanto outros deixam seu país para viverem nas Américas. O segundo é a própria greve de fome dos presos políticos do século XX. A partir desses dados, o alimento desse pão, não deixa de ser a visão de uma Irlanda cujas guerras produzem uma anorexia generalizada - para utilizar novamente o termo de Edna Longley.

Sendo assim, Heaney exemplifica e endossa a conclusão apresentada pela crítica no seu artigo, pois ela observa que, nessa multiplicidade de assuntos que os escritores irlandeses do Norte abordam, há sempre uma ligação com a divisão e os assuntos políticos. Com isso, a tradução de João da Cruz é um dado para que o poeta demonstre a impossibilidade de um canto da claridade, visto que ele não consegue abandonar os temas irlandeses. Segundo Longley, pode-se:

definir a literatura como lugar primordial onde a língua muda e as categorias anoréxicas são expostas (nem sempre como um processo consciente). Escritores nascidos em um ambiente demasiadamente determinado e definidos por uma tensão entre simplicidades políticas e complexidades 
culturais, sentem-se impelidos a redefinir: a explorar e criticar a língua, imagens e categorias, estereótipos e mitos. A escritura do Norte não se encaixa na forma binária talhada pelo Nacionalismo e pelo Unionismo. Ela amarra as grades cruéis com inúmeros detalhes. Ela inunda as margens e manifesta uma teia de afiliações que se estende além de qualquer área central - até o resto da Irlanda, da Bretanha, da Europa. Mas a variedade de estilos, histórias, mitos e influências talvez só podem entrar na imaginação por causa dessa zona de 'problemas e separação' (frase de John Hewitt). Todas as 'tradições culturais' são levadas em consideração em algum momento; nem todas as divisões políticas descartadas. (LONGLEY, 1994, p. 194) ${ }^{159}$

Podemos compreender que até a imagem da grade que ela fala, está presente no poema quando o padre de seu passado surge. Podemos observar o poeta lutando com uma negritude histórica, como o anjo de Benjamim, que, mesmo sendo empurrado para o futuro, não se desvencilha dessa fonte escura que poderia ter uma plenitude do pão - da própria solidariedade da alimentação.

Nesse sentido, as metáforas bíblicas que definem essa passagem - Jesus como sendo a fonte e pão - são subvertidas ao lamento final de cada estrofe - "although it is the night". O efeito quase hipnótico desse verso de seis sílabas poéticas e sonoramente semelhantes ao original - "aunque es de noche" - servem para interar que, embora seja noite, a possibilidade do conhecimento é muito limitada e fragmentada, ou mesmo dispersa na divisão social. A intertextualidade com a Bíblia se dá principalmente com o Evangelho de João, do qual "transparece um Cristo glorioso..." e cujo valor se dá pela "originalidade... bem como o valor histórico de suas informações... [e] longo período de reflexão teológica sobre Cristo e os fatos de sua vida". ${ }^{160}$ Sendo escrito quase cem anos após a morte de Jesus, ao focar no aspecto espiritual do mesmo, esse livro surge como uma fonte de luta contra heresias e a gnose do docetismo. A apropriação do poeta na chave de expurgação dos

\footnotetext{
${ }^{159}$ Original: I called literature the primary place where language changes and anorexic categories are exposed (not always a conscious process). Writers born into an over determined, over-defined environment, into a tension between political simplicities and cultural complexity, have felt impelled to redefine: to explore and criticise language, images, categories, stereotypes, myths. Northern writing does not fit the binary shapes cut out by Nationalism and Unionism. It trellises the harsh girders with myriad details. It overspills boarders and manifests a web of affiliation that stretches beyond any heartland - to the rest of Ireland, Britain, Europe. But the range of styles, histories, myths and influences perhaps could only enter the imagination in this unique zone of 'problems and cleavages' (John Hewitt's phrase). All the 'cultural traditions' count somewhere; nor are the political divisions discounted. (LONGLEY, 1994, p. 194).

${ }^{160}$ Contextualização dos relatos desenvolvidos pelo discípulo e evangelista João. Embora sendo uma edição católica, o autor deixa transparecer o porquê da diferença do seu livro. (Jiménez. Bíblia Sagrada, 1989, p. 1094).
} 
pecados, mostra-se, ainda, como uma heresia também, pois além de não cumprir sua penitência como deveria, ele ainda profana a luminosidade de Jesus com a escuridão e os problemas da história irlandesa, cujo pomo da discórdia é revertido também à religião. Sendo assim, sua penitência torna-se mais um pecado que chegará ao seu ponto culminante no último poema.

Ainda sobre o caráter confessional do poema, é notório o fato do poeta descrever a penitência prescrita pelo sacerdote e omitir o pecado. Isso nos leva ao fato de ele já tê-lo revelado pelas outras seções. Portanto, chegamos a um ponto em que a própria atitude de penitência é uma constante em seu poema, como se a sua existência de poeta, em meio a uma realidade de guerra, fosse um crime. Se por um lado ele possui essa culpa, por outro ele a expurga através do ato confessional. Essa atitude, segundo o filósofo norte-americano Paul de Mann

é superar a culpa e a vergonha em nome da verdade: é um uso epistemológico da linguagem, nos qual os valores éticos do bem e do mal são sobrepujados por valores de verdade e falsidade, uma das implicações sendo a de que vários vícios como a concupiscência, a inveja, a cobiça e outros são vícios principalmente porque nos obrigam a mentir. Afirmando as coisas como elas são, a economia do equilíbrio ético é restaurada e a redenção pode-se iniciar na atmosfera de uma verdade que não hesita em revelar o crime em todo seu horror. (MANN, 1996, p. 312)

Muito provavelmente o autor tem em mente essa característica do ato confessional quando escreve o poema, principalmente porque afirma seu pecado, e depois o tenta compensar com a penitência - e até mesmo recuperando aqueles mortos que apareceram em sua vida.

\footnotetext{
And from these two a third current proceeds which neither of these two I know, precedes although it is the night.
}

The eternal fountain hides and splashes within this living bread that is life to us although it is the night.

Hear it calling out every creature. And they drink these waters, although it is dark here because it is the night.

I am repining for this living fountain.

Within this bread of life I see it plain 
Although it is the night.

(O. G., p. 267)

Embora Heaney tente se desculpar, ele não consegue, pois a limitação lingüística da tradução e a repetição da noite assumem um tom mais acusador ainda. Com isso, há até um caráter falso em seu arrependimento, porque ele afirma a sua aflição com a fonte escura, ou seja, o estar descontente com a história é também um crime porque, nesse momento, ele não se vê envolvido nesse mesmo mecanismo de exclusão e confrontos. Continuando com Mann:

a única coisa que temos que temer é que ela de fato irá desculpar o confessor, tornando assim a confissão... redundante no momento em que se origina... uma vez que a confissão existe apenas como enunciado verbal... como então podemos saber se estamos de fato lidando com uma confissão verdadeira? (MANN, 1996, p. 312)

No poema podemos ver que essa confissão pode ser falsa e verdadeira: quando confere um ar de superioridade ao poeta cujos pecados foram superados, ela é falsa, pois revela arrogância. Contudo, se levarmos em conta sua aflição e a preocupação com os outros - aqueles que bebem dessa fonte - pode também ser um ato solidário e positivo pelo qual ele se identifica com as pessoas que entraram nessa leva de água escura e barrenta. Esses podem ser identificados com as vítimas da sociedade irlandesa: os que morreram na Grande Fome, e aqueles que tiveram o mesmo destino por estarem fazendo greve de fome. Logo, a atitude do poeta é dúbia: mesmo com um ar de superioridade, ele tenta compreender como funciona essa história em camadas que devora os cidadãos. Sendo assim, o caráter arqueológico da sua lírica é retomado.

\section{A SOLIDARIEDADE}

Chegando na última fase do poema vemos o quanto dessa dialética entre solidariedade e superioridade resiste. Parece-nos que o poeta articula a questão da coletividade fraterna e a polifonia subjetiva como antídoto contra as atrocidades que encontra em sua peregrinação. A partir das vozes literárias e de pessoas, ele tenta manter uma relação com a sua sociedade. Surge então, a esperança em um indivíduo melhor que 
poderá livrar-se de sua determinação social, ou seja, através desse poderá ser concebido um cidadão que construa uma sociedade não mais dos pântanos, ou seja, enterrada em um passado anoréxico, mas do ar, representada pela liberdade do pássaro Sweeney. Entretanto, assim como o herói mitológico, esse indivíduo deve aprender com o passado e seu sofrimento, desenvolvendo uma consciência histórica. No caso do poeta, essa também envolverá o conhecimento de outras culturas e nações por meio do deslocamento: o exílio. Não é a toa que ele escolhe James Joyce, escritor cosmopolita e exilado, para ser seu guia nessa nova fase.

A elevação da subjetividade é um tema recorrente no trabalho de Joyce, pois em seus primeiros livros ele desenvolve um mecanismo de exteriorização e interiorização: enquanto Dubliners explora o estado de paralisia da sociedade, The Portrait of the Artist as a Young Man demonstra uma elevação subjetiva personificada em Stephen Dedalus. Heaney também o faz nesse poema, pois através do diálogo com a tradição, e com a história, ele constrói esse eu lírico multifacetado e recortado. De acordo com Cairns e Richards:

como James Joyce escrevera ao seu editor em maio de 1906: 'Eu dei o primeiro passo na liberação espiritual do meu país' (JOYCE, 1975, p. 88), e visto que o país é formado por um composto de indivíduos, a libertação nacional era essencialmente, e primeiramente, uma liberação dos indivíduos. Dubliners, o assunto da carta de Joyce, é o seu primeiro testemunho em relação à necessidade e da libertação irlandesa, bem como de sua natureza... As histórias lidam com o que pode ser chamado do nascimento de uma consciência tão multifacetada quanto a do protagonista que é interpelado por uma sociedade cuja realidade completa só pode ser compreendida, em termos de sua rede casual, quando o leitor, junto com a emancipação do protagonista Gabriel Conroy, percebe que aquilo que a Irlanda perdeu pode ser recuperado se a paralise não se tornar um estado permanente da nação ainda inexperiente. (CAIRNS; RICHARDS, 1988, p. 80) ${ }^{161}$

\footnotetext{
161 Original. As James Joyce wrote to his publisher in May 1906: 'I have taken the first step towards the spiritual liberation of my country' (Joyce, 1975, p. 88), and since the country was conceived of as a composite of individuals, the national liberation was essentially, and primarily, a liberation of the self. Dubliners, the subject of Joyce's letter, is his first testimony to the need for, and nature of, Irish liberation... The stories then deal with what may be the termed the birth of consciousness as the multi-faced collective protagonist is interpellated into a society whose full reality can only be comprehended, in terms of its causal network, when the reader, along with the final emanation of the protagonist Gabriel Conroy, comes to perceive what Ireland has lost must be regained if paralysis is not to become the permanent state of fledging nation. (CAIRNS; RICHARDS, 1988, p. 80)
} 
Sendo assim, Heaney retoma esse mote de modo a tentar criar uma subjetividade que seja liberta das pressões políticas e religiosas, embora esteja fazendo uma peregrinação católica.

Se por um lado a subjetividade deseja seguir o exemplo de Joyce, por outro, compreendemos que essa ainda está vacilante, pois nas duas primeiras estrofes ele caracteriza, através de um verso truncado e marcado pelas plosivas, sua subjetividade como convalescente, e mesmo assim, essa não sabe se será guiada, ou guiará a mão amiga que se apresenta. Com um verso mais brando e ameno conseguido pelos sons sibilantes, surge o sentimento de amizade e, paradoxalmente, a indecisão de guiar ou se deixar guiar. Assim, compreendemos que esse fantasma não está somente no exterior, mas no seu interior, como um desejo que se prolonga. Na terceira estrofe, comparado com a primeira, temos duas imagens de impossibilidade: enquanto Heaney convalesce, Joyce parece cego e ainda usa uma bengala. No entanto, ele se materializa como uma presença imponente que o enche de admiração. $\mathrm{O}$ dado da diferença está no fato de o poeta abandonar as imagens naturais que predominaram ao longo das estações - com a exceção da morte do dono do armazém - e colocar o fantasma em meio à buzina dos carros e do barulho da cidade. Sendo assim, o poeta procura mais uma vez deslocar o local de sua escrita de modo a sugerir que seus pecados estão finalmente sendo expurgados, e o escritor, como uma voz profética, anunciando o seu veredicto para os trabalhos futuros.

Devido à evocação, mesmo que pequena, da cidade, compreendemos que a morte do naturalista (referência ao título de seu primeiro livro) ainda está sendo processada nessa parte, pois ele pretende vê-la com os olhos cosmopolitas de James Joyce, e através da suas vogais que ultrapassam oceanos e chegam à cidade. Sobre o tema das cidades, Candido escreve:

o sentimento genérico despertado em nós por uma cidade repousa, a bem dizer, na limitada experiência... quando anunciamos um nome de lugar brota ao lado a visão do conjunto, graças à qual julgamos apreender a substância como se as diferentes emoções se ordenassem regularmente num cartãopostal abstrato (CANDIDO, 2004, p. 51)

Nesse sentido, a evocação dos sons da linguagem e da obra literária de Joyce faz com que o poeta ordene a sua experiência na cidade, principalmente a de Dublin, pois esse é um dos locais que se refugia em seu exílio. Entretanto, ao invés de conversar com o poeta, 
Joyce assume a fala e profere uma série de conselhos ao artista, que podem ser associados à voz do reencontro com um deus. Com isso, as peregrinações cíclicas em torno dos leitos de orações que sempre trouxeram alguém que já havia morrido, fazem com que ele chegue a um ponto fixo. Porém, ao contrário da missa que é celebrada no último dia da peregrinação, aqui ele comunga com o espírito do artista irlandês, o qual o faz retornar para o espaço da vida urbana, cosmopolita e do conhecimento intercultural.

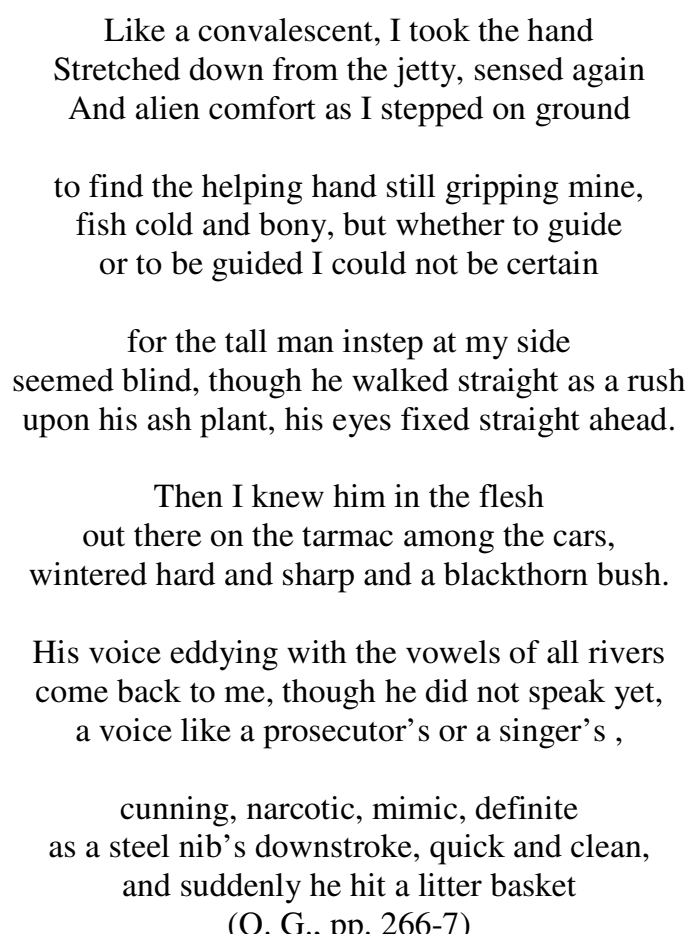

Um elemento importante para compreensão do poema é o fato da voz do romancista adquirir contornos de duas profissões distintas: a de promotor e cantor. Enquanto um acusa e tem o poder de condenar a pessoa à morte, o outro encanta e promove o prazer. Sendo assim, a arte feita por Heaney, e inspirada por Joyce, é acusadora de uma sociedade dividida e injusta, mas causa prazer pela sua beleza e por criar uma consciência sobre os problemas mais imediatos. Com a intenção de solidificar essa voz, o poeta ainda a caracteriza como aquela que faz movimentos circulares em torno de todos os rios. Há um paralelismo muito grande entre a voz do poeta e a do fantasma com o qual ele conversa, visto que Heaney andou em círculos durante todo o poema, movimento que mimetiza a sua vida de estar sempre se deslocando, mas nunca perdendo o eixo do seu lugar de origem: a Irlanda imaginada e histórica, com todos os seus problemas identitários e sociais. As 
circularidades elípticas são muito similares ao triskle da mitologia celta, que na sua origem indo-européia (civilização que dá origem aos celtas), significa um equilíbrio de forças, propulsor de um movimento contínuo e infindável. Portanto, ao ouvir Joyce, ele ouve um eco de sua própria voz que se perde nos lugares por onde ele passou.

Atentando sobre as tercinas que o poeta volta a empregar, temos mais subsídios para relacionar esse poema ao triskle celta. De acordo com Cláudio Quintino:

os Celtas consideravam o três como sendo um número sagrado. A primitiva divisão do ano em três estações - primavera, verão e inverno - pode ter tido seu efeito na triplicação de uma deusa da fertilidade com a qual o curso das estações era associado. Ou seja, o triskle... está associado ao fluxo das estações... e por conseqüência representa a própria Deusa. Ademais, temos uma conexão óbvia com as três faces da Deusa (Donzela, Mãe e Anciã), bem como às três fases da lua (crescente, cheia e minguante), ou ainda com nossa natureza tríplice (corpo, mente e alma).... Sua presença em achados arqueológicos em terras celtas, da Irlanda à Europa Oriental, atesta a ampla adoção pelos Antigos (QUINTINO, 2002, p. 21).

Na re-significação dessa simbologia, compreendemos que Heaney, valendo-se das tríades corpo-mente-alma e terra-céu-mar, configura a sua, eu (casa)-outros (exílio e tradição literária)-cosmopolitismo (eu e os outros em um espaço de relações intercambiais). Entretanto, esse terceiro momento ainda não foi atingindo, pois Joyce o retira de um devaneio, e batendo em uma lata de lixo - imagem extremamente citadina e rebaixada - faz com que o poeta preste atenção no que ele tem para dizer.

Quando Joyce assume a voz do poema, suas palavras tornam-se mais obscuras para Heaney, pois mesmo insistindo para que ele cultive uma luxúria de escrever, o romancista atesta que essa deve ser como mãos na noite, cena que remete ao ato de oração e penitência. A menção de que ele pode escrever o céu com suas mãos durante a noite - "heaven like your hands at night" - cria uma antítese, pois se o "work-lust" pode estar associado ao prazer sexual, esse é também condenado pela religião e pelas preces. Ainda em movimento espiral a voz continua ordenando que ele deve partir dali, pois agora ele está com o jejum feito, com a cabeça livre e perigosa. As ressalvas são para que ele não seja tão honesto, nem preste tanta atenção aos lutos e aos mortos. Assim, ele deve dizer o que realmente pensa e não o que seria adequado em determinada situação, ou usando a metáfora do poema, ele deve começar a cantar de seu modo - não daquele determinado por seu lugar de origem. $\mathrm{Na}$ 
continuação das estrofes, o poeta não se sente mais admirado com o escritor, mas enfadado com tal conversa, pois além de não acrescentar um dado novo a sua lírica, Joyce zomba de suas raízes e preocupações. Com isso, esse é o último momento que o leitor ouve a voz de Heaney como ele mesmo - há enfado, culpa e pressão em suas mãos:

\author{
with his stick, saying 'Your obligation \\ is now discharged by any common rite. \\ What do you most do on. \\ The main thing is to write \\ For the joy of it. Cultivate a work-lust \\ that imagines its heaven like your hands at night \\ dreaming the sun in the sunspot of a breast. \\ You are feasted now, light-headed, dangerous. \\ Take off from here. And don't be so earnest, \\ so ready fro the sackcloth and ashes. \\ Let go, let fly, forget. \\ You've listened long enough. Now strike your note'. \\ It was as if I had stepped free into space \\ alone with nothing that I had not known \\ already. Raindrops blew in my face \\ (O. G, pp. 267-8)
}

Após o som dos pingos de chuva e o silêncio produzido pela pausa do fantasma, Joyce continua o seu discurso proferido a um sujeito completamente exausto e indeciso perante si mesmo e a todo o exterior que o cerca. Nesse momento, parece que toda a determinação do que vem de fora domina a subjetividade e essa é anulada frente a essas pessoas com as quais ele troca informações. Sendo assim, suas últimas palavras compõem uma declaração contra toda a lírica que o poeta fez durante a sua vida: a de ouvir as pessoas, tentar compreender as reclamações e, de alguma forma, elevar práticas culturais rurais e provincianas. Juntamente com o desejo de uma subjetividade única, o autor comprova que isso não passa de uma falácia da qual ele deve escapar. Conseqüentemente, o material referido por Joyce não passa de uma idealização com a qual ele não consegue lidar, por isso não ouvimos a voz de Heaney como ele mesmo, mas apenas como esse desejo afirmado na pessoa do escritor modernista. O embate entre o cosmopolita e o rural é visto aqui como um ponto determinante, pois, para anular essa dualidade, ele deve nadar, ou seja, novamente sair dessa atmosfera hostil. 
Quando a possibilidade de um novo exílio entra em cena, notamos que o exílio da segunda parte - aquele no qual ele rememora toda uma vida distante das pessoas que sofreram com a guerra civil - continua até certo grau presente. Entretanto, esse deve deixar de somente trazer memórias de casa, mas abarcar o observado em um outro lugar e, principalmente, "manter uma tangente quando o círculo se amplia", ir contra o préestabelecido e as convenções. Esse caminho às avessas é uma herança também da posição revolucionária de Joyce, visto que:

a Irlanda dos nacionalistas e dos literatos do revival representada por Joyce em suas histórias da vida pública é esquálida e mercenária; uma terra não da aristocracia nem dos trabalhadores rurais, mas dos membros de uma pequena burguesia egoísta e miserável que... estava apenas interessada n'os spondulics'... muito da crítica recente foi redirecionada em estabelecer as credenciais políticas de Joyce, mas seria uma afirmação exagerada em indicar que o candidato a nacionalista se aproximaria de uma critica marxista ao capitalismo. A orientação de Joyce é política, mas mais um lamento do que um programa (CAIRNS; RICHARDS, 1988, pp. 82-3) ${ }^{162}$

Nesse sentido, suas apostas estavam em uma arte que não fosse relacionada a nenhum desses dois grupos. Porém, mesmo percebendo tais contornos na obra de Joyce, Heaney permanece silencioso e perplexo ao ouvir essas palavras, como se, mesmo tendo fé no que ele diz, não conseguisse aceitar totalmente essa libertação.

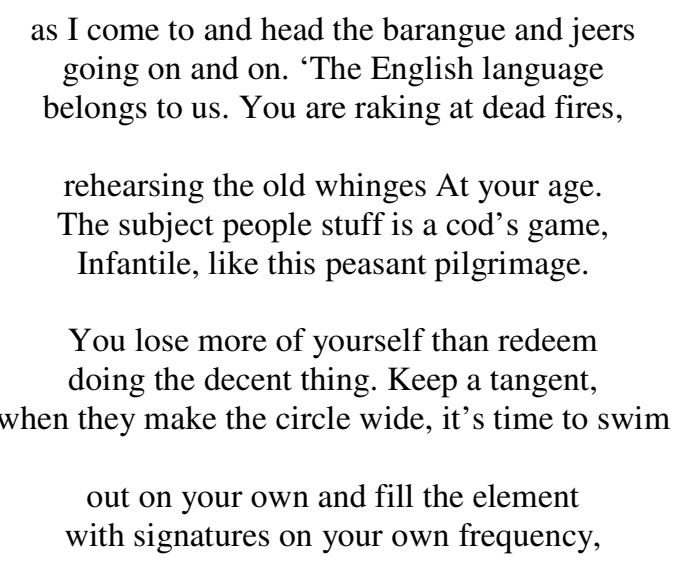

\footnotetext{
162 Original: The Ireland of both nationalist and Literary Revivals captured by Joyce in his stories of public life is squalid and mercenary; a land of neither aristocrats nor peasants, but members of a self-interested and shabby petit-bourgeoisie who... are only interested in... 'the spondulics'... much recent criticism has been directed to establishing the political credentials of Joyce, but it wound be an over-statement to see such observations on the nationalist candidate as indicating anything approaching a Marxian critique of capitalism. Joyce's orientation is indeed political, but it is more a lament than a programme. (CAIRNS; RICHARDS, 1988, pp. 82-3)
} 
echo soundings, searches, probes, allurements

elver-glems in the dark of the whole sea'.

The shower broke in a coldburst, the tarmac

fumed and sizzled. As he moved off quickly

the downpour loosed its screens his straight walk.

(O. G., p. 268)

Certamente a não aceitação completa desses paradigmas literários estaria relacionada à situação de uma Irlanda do Norte, cujo processo de libertação, ainda na década de oitenta, não havia sido resolvido. Portanto, uma pergunta que podemos nos fazer é se Heaney possui uma credencial política. Ou se essa sua descrença em uma subjetividade única e imutável seria parte de um processo histórico que o deixasse igualmente paralisado em um ponto, apesar de todos os movimentos feitos pelas espirais dos triskle. Essas são perguntas relacionadas com a posição cosmopolita e global de um autor irlandês que ganha o prêmio Nobel de literatura exatamente no momento em que os problemas civis da Irlanda do Norte estavam sendo resolvidos, parcialmente, devido à intervenção das políticas de paz americanas do governo Bill Clinton. São essas as perguntas que o leitor deve carregar para as próximas fases de sua literatura e que observaremos, mais precisamente, no seu livro mais recente. 


\section{CONCLUSÃO}

I fasted for some forty days on bread and buttermilk, For passing round the bottle with girls in rags or silk,/ In country shawl or Paris cloak, had put my wits astray,/ And what's the good of women, for all that they can say

\{Is fol de rol de rolly O.\}

Round Lough Derg's holy island I went upon the stones, I prayed at all the Stations upon my matrow-bones,/ And there I found an old man, and though, I prayed all day/ And that old man beside me, nothing would he say

\{But fol de rol de rolly O.\}

(YEATS, W. B - "The Pilgrim")

A partir da análise do poema "Station Island" (Station Island, 1984) pudemos perceber as formas pelas quais o escritor irlandês do Norte Seamus Heaney expurga as tensões subjetivas e históricas tanto de sua arte, quanto de seu lugar de origem. Embora não se referindo abertamente ao mecanismo de exílio, compreendemos que esse é uma constante em todo poema, assim como uma armadura de clave da qual o escritor não pode se desvencilhar enquanto compõe a sua sonata dissonante. Se por um lado temos o exílio como a tonalidade predominante de toda composição poética, por outro, consideramos os três movimentos, correspondentes aos nossos três capítulos, elementos distintos que, quando congregados, constituem a sonata da polifonia da poética do exílio. O próprio poeta classificou "Station Island" como um poema permeado de movimentos (HEANEY, 2006), portanto não podemos ignorar o fato de haver, dentro de cada unidade, partículas ainda menores. Essas, por conseguinte, podem ser denominadas temas através dos quais o sujeito poético revela as nuanças e alternâncias de seu afastamento da terra natal.

Dentro das doze estações do poema, Heaney pode orquestrar fases de uma vida inteira passada a limpo. À luz do exílio, ele retorna à infância, à fase adulta e ao presente, cujas incertezas e angústias o fazem meditar sobre a credibilidade da poesia em abarcar momentos de descoberta, alegria, dor, e liberação. Aliada ao afastamento metafórico e factual, a objetificação da subjetividade oscilante possibilita o poeta metamorfosear-se em inúmeros fantasmas que o impulsionam a criar uma nova arte poética. Entretanto, em vez de trazerem harmonia e serenidade ao poema, tais espectros do passado fazem com que a subjetividade tenha de entrar em um embate constitutivo com outros escritores de dentro e 
de fora da tradição literária. Com isso, estruturas métricas, pés poéticos, rimas e ritmos se fragmentam em uma polifonia de vozes e estilos que o impedem de atingir um ideal de beleza subjetiva, afastada da história colonial irlandesa.

Ao assumir a voz do Outro, ou melhor, de Outros, de modo a ouvir a sua própria autobiografia, Heaney pronuncia as divisões identitárias geradas pelas políticas de poder que subjugaram a Irlanda do Norte. Sendo assim, o autor entrelaça, rompe e subverte fragmentos sonoros com a intenção de, implicitamente, escrever a descontínua experiência coletiva de sua nação. Com isso, em vez de um percurso solitário de orações, como deve, supostamente, ser feita a Peregrinação de São Patrício, o poeta consegue dramatizar uma incoerência histórica que afeta a todos os cidadãos de sua ilha. Esse processo é semelhante ao que argumenta o poeta crítico literário Octavio Paz:

o poema é histórico de duas maneiras: a primeira, como produto social; a segunda, como criação que transcende o histórico, mas que, para ser efetivamente precisa se encarnar de novo na história e se repetir entre os homens... o poema dá de beber a água de um perpétuo presente que é também o mais remoto passado e o futuro mais imediato. (PAZ, 1956, pp. 228-9)

Desta maneira, a característica mais constitutiva e fundamental da poesia, sua métrica, torna-se, na polifonia da poética do exílio de Seamus Heaney, seu caráter mais particular, localizado e histórico. Como uma máquina propulsora de versos, metáfora usada por Heaney em "The Turnip Snedder" (District and Circle, 2006), ele fixa sua subjetividade na pluralidade e diversidade para que seu exílio tenha apelo, simultaneamente, ao local e ao global.

Nosso primeiro capítulo, ou movimento, para continuar com a imagem da sonata, aborda o tema da objetificação da subjetividade como uma instância que revela "estruturas subalternas", na terminologia pioneira da indiana Gayatri Spivak, ou o "efeito subalterno", de acordo com o crítico irlandês David Lloyd, na sociedade irlandesa. Para que Heaney, na sua faceta ainda em fase de formação, reconheça-se como um produto de camadas camponesas, rurais e exploradas, ele ouve conselhos daqueles que contribuíram para seu crescimento. Sendo assim, o poeta concebe diálogos imaginários com o amigo Simon Sweeney, e/ou o rei mitológico Sweeney, da lenda celta Sweeny Astray, traduzida pelo autor em 1991. Depois, encontra-se com o poeta William Carleton, autor de um dos 
primeiros poemas dedicados à Ilha das Estações, e recorda-se, galgado em recursos estilísticos provindos do Surrealismo, do funeral de uma garota e da perda do animal de estimação durante a infância. $\mathrm{O}$ primeiro movimento de vozes subalternas finda com o aparecimento de um padre que fora enviado às missões e retorna com inúmeros traumas psicológicos resultantes de seu exílio.

O resultado da análise desse primeiro movimento foi a de que o embate métrico, conjuntamente com a possessão de pés poéticos provindos da literatura inglesa em oposição à irlandesa, traduz a "violência epistêmica" das sociedades pós-coloniais. Entretanto, a compreensão dessa violência, por parte do poeta, além de reiterar, no presente da leitura poética, contínuos históricos com o passado, sugere um "saber" além do "poder". Em outras palavras, esse sujeito em formação cuja aspiração é a liberdade - como retratado na parte III - adquire consciência histórica para compreender politicamente o lugar em que é gerado. Contudo, a constante cobrança por parte das instâncias familiares e sociais o faz espelhar-se naquele que é exilado de seu país, ou seja, no padre despedindo-se da Irlanda onde nascera. Assim, liberdade dessa atmosfera opressora e pálida da Irlanda é o desejo do poeta quando descobre a verdadeira natureza de sua poesia: a fusão de contrários, o desprazer e o sofrimento.

Entretanto, mesmo concretizando o afastamento, no segundo capítulo, entendemos que a subjetividade não consegue lidar de forma pacífica com o exílio, uma vez que a guerra civil, cujo palco era as ruas de Belfast, afetava diretamente seus amigos e entes queridos. Portanto, o poeta retoma os espectros dos professores da escola onde estudou e de Patrick Kavanagh, para verbalizar a sua saída da Irlanda do Norte. Porém, à medida que sai, é ironizado pelo poeta e esvaziado de sonhos em relação ao futuro. Sendo assim, já no exílio, Heaney encontra-se com a história do país impresso no corpo da mulher com quem tem sua primeira experiência sexual. Essa, por ser descrita como Beatriz de Dante, sugere paralelos entre a Peregrinação do autor italiano e do irlandês. Todavia, enquanto a figura feminina para um é o guia de sua entrada do poeta no Paraíso, o imaginário do outro pressupõe o caminho rumo às portas do Inferno. Sendo assim, nas últimas duas partes, o poeta passa rememorando duas vítimas dos confrontos e um amigo do qual não pôde participar do funeral, visto que estava fora do país. 
Do sentimento de culpa, somado ao desejo de uma poética que o redima por ter-se afastado durante praticamente todo período das guerras, Heaney não reduz esteticamente a sua poesia, mas inova textualmente usando a cadência do trímetro italiano: verso intricado e complexo que garantiu força à poética de Dante Alighieri. Da mesma maneira, o paralelismo entre as vítimas da guerra e o sofrimento de Jesus Cristo confere características transcendentes a essas pessoas, como se, através de seus versos, elas pudessem continuar vivas e relatando o sofrimento da guerra. Logo, a culpa confere um grau de testemunho a sua escrita, a qual não deixa o leitor esquecer o contexto de onde o poeta escreve. Por essa razão, o conflito não está apenas

na história, e sim nas entranhas do poema, e consiste no duplo movimento da operação poética, transmutação do tempo histórico em arquetípico e encarnação desse arquétipo num agora determinado e histórico. Esse duplo movimento constitui a maneira própria e paradoxal de ser da poesia. Seu modo de ser histórico é polêmico. Afirmação daquilo que nega: o tempo e a sucessão. (PAZ, 1956, pp. 229-30)

Se, nas palavras de Paz, a poesia é histórica e complexa, mais complexa ainda é a forma pela qual ela tenta livrar-se da história. Isso ocorreria exatamente no terceiro movimento do poema, o qual, em nossa divisão, é o terceiro capítulo, em que Heaney refugia-se da história de fome e privação irlandesa nas danças indígenas, nos versos espirituais de Juan de la Cruz e no tom castrador de James Joyce. Ao equiparar a Grande Fome à anorexia do grevista da fome Ted Hughes, o poeta cria um mecanismo de desfamiliarização. Sua morte, juntamente com a imagem de herói idealizada pelo jovem, o faz retornar ao som dos trompetes do jazz e das festividades Lakotas ameríndias como forma de libertação e conhecimento. Surgiria como um primeiro fruto dessa luz a epifania, aos moldes joyceanos, provinda da contemplação do cálice tirado de uma peça de teatro. Fiel à tradição epifânica que irrompe a mudança de uma vida inteira, esse objeto faz o autor transformar a poética de uma vida inteira.

Retornando ao pagus celta e à disciplina cristã, Heaney transmuta-se, novamente, no rei Sweeney, que foi condenado, por seus pecados, a sobrevoar a Irlanda como um pássaro. Em rumo à luz, o poeta restaura o amor que o cálice contemplado faz recordar e, traduzindo Juan de La Cruz, expurga o pecado de retirar-se do seu lugar de origem. Na sequiência, surge o pão da vida que o faz, novamente, crer no poder transformador da arte. 
Ao encontrar-se com Joyce, embora haja o pessimismo provindo de suas duras palavras, Heaney termina sua peregrinação, ao mesmo tempo artisticamente saciado e absorto pelos conselhos do escritor. No entanto, a luminosidade e a chuva do final o fazem, sugestivamente, entrever a possibilidade de um novo começo, no qual essa sinfonia intertextual e antropofágica provinda do exílio acopla ao seu estilo literário as matérias para novas explorações.

Acreditamos que a peregrinação do escritor esclarece muito dos problemas enfrentados pelos escritores, principalmente os poetas do Norte da Irlanda ao tentarem, abertamente ou não, esboçar uma resposta enviesada perante os dilemas enfrentados durante longos e traumáticos anos. Para a crítica Edna Longley (2005, p. 220) devido à ininterrupta auto-reflexão e intertextualidades, os poetas irlandeses do norte deixam suas opções abertas ao exercício da diferença, algo como acontece no final do poema quando não ouvimos a voz de nenhum outro escritor, apenas os ruídos dos pingos da chuva. Esse retorno ao natural apresenta a possibilidade de reconstruir a história irlandesa como um antídoto contra os traumas do presente. Ao verbalizar os problemas e as histórias subalternas que foram impressas no mais profundo da linguagem, surge-se a possibilidade da cura e da busca de algo maior, talvez uma poética que consiga ser verdadeira, porém não culpada, mas reflexiva e consciente.

Desta maneira, a poética que Heaney apresenta posteriormente será semelhante ao triskle da mitologia celta cuja força está em reunir as múltiplas subjetividades do autor, o seu exílio culpado e um novo lugar: a metafísica da redenção e da compreensão. A partir dessa solução simbólica, o poeta caminha para uma arte que não se fecha completamente na ilha, uma vez que um mundo globalizado e interconectado onde o rápido fluxo de histórias, culturas e trocas econômicas faz com que as distâncias sejam diminuídas e haja mais similaridades dentro das próprias diferenças locais. Ao traçar contínuos históricos, o poeta resiste, tecendo possíveis resoluções para problemas sociais . Assim, as razões pelas quais a Academia Sueca louvou suas obras "de beleza lírica e profundidade ética, que exaltam os milagres do cotidiano e do passado vivo', e a habilidade com que Heaney evita 'os termos convencionais' ao abordar a complexa realidade política da Irlanda do Norte" (ARANTES 1998, p. 13), tornam-se ainda mais fortes, uma vez que ele abre ainda mais o leque de problemáticas abordadas. Para Edna Longley (2002, p. 221), o mecanismo de alternância, 
em que os poetas do norte ora se fixam em um otimismo esperançoso e à redenção, ora em um pessimismo avassalador e à culpa, estaria relacionado às raízes transcendais, como algo que está além dos horizontes geográficos e visíveis. Esse algo, portanto, para a crítica é o próprio processo de paz da Irlanda do Norte, cujos efeitos já foram sentidos no social, mas não no psicológico.

Ao longo das estações propostas pela peregrinação, o leitor tem a possibilidade de observar como Heaney encontra-se consigo mesmo através dos vários encontros com indivíduos do passado, presente e futuro de sua sociedade. Novamente, ao usar o arquétipo de Paz para conferir à arte o conhecimento histórico, o poeta propõe, nos termos usados pela filósofa Hannah Arendt, um espaço de ação, dentro da condição humana (ARENDT, 2007). Desejamos argumentar que tal condição, ao invés de uma instância ideológica que anula as diferenças sociais unindo os seres humanos de maneira harmônica, denuncia as diferenças.

Levando em consideração o fato das relações políticas serem vividas dentro da esfera da pluralidade ao colocar sua peregrinação em termos dialógicos com outras subjetividades, pessoas, estilos, escritores, culpas, tradições e culturas, o poeta transforma sua arte em uma alegoria do espaço público aberto ao exercício da política e da participação. Sendo a Irlanda do Norte um lugar cujo sectarismo passado imprime suas marcas no presente, percebemos que o poeta procura entrever um espaço utópico de solidariedade em que as inter-relações entre passado e presente consigam ser feitas de modo a efetivar o processo de paz. Se para Arendt as respostas e soluções futuras só podem ser alcançadas no "âmbito da política prática, sujeitas ao acordo de muitos; jamais poderiam se basear em considerações teóricas ou na opinião de uma só pessoa", (ARENDT, 2007, p. 13) como se fosse possível apenas uma resolução cabível.

Portanto, a arte poética de Heaney em "Station Island", por se assemelhar ao debate performático e político, constituído de trabalho e ação, propõe uma narrativa que se resignifica e re-codifica à medida que faz mudar a direção de fluxos hegemônicos e possibilita a existência de um contra-discurso cuja inclusão e solidariedade sejam sua précondição de existência. Conseqüentemente, a forma de pensamento criativo proposto pelo poeta, ao travestir-se do outro, assumir o outro e ser cobrado pelo outro, representa o palco histórico não só da Irlanda do Norte, mas de outras formas criativas cuja vitalidade nos faz 
questionar convenções e costumes herdados e propagados como o desenvolvimento natural de todas as sociedades. Em razão disso, essa arte audaciosa, a nosso ver, pretende engendrar transformações futuras. A força poética de Heaney está, deste modo, em sua capacidade de questionar esses valores estáticos, e revigorar o todo do pensamento social, garantindo inovadoras e dinâmicas formas de questionamento.

De modo a comprovar essa linha de pensamento, o próprio Heaney faz uma instigante revelação sobre a característica utópica de sua arte, demonstradora de que o poeta cria inter-relações que propõem a arte do que poderia ser, ou seja, uma configuração social mais justa e igualitária:

Orfeu, não nos esqueçamos, persuadiu o Rei dos Mortos a mudar as leis da terra dos mortos para permitir que Eurídice voltasse à terra dos vivos. E Orfeu... fará o que os poetas sempre fazem ouvir a música do que está realmente acontecendo, mas respondendo a ela tocando a música do que pode acontecer. (HEANEY, 2002) ${ }^{163}$

Desta maneira, como podemos observar a partir de sua analogia com o símbolo de todos os poetas, Heaney reitera que a sua arte será moldada pela sociedade e, devido a essa moldura, não poderá deixar de salientar o modo como problemáticas sociais acabam afetando as relações humanas, como sua história afetou sua decisão de exílio e sua relação com seus próximos e com a própria poesia. Entretanto, devemos atentar para o detalhe de que esse "o que pode acontecer" tem um caráter dúbio, tanto trágico e sombrio, quanto vitorioso e radiante. Em razão disso, retornamos ao conceito da negatividade adorniana, em que o artista deve ininterruptamente questionar, porém isso nunca será conseguido sem o conhecimento do sofrimento, ou, seguindo a peregrinação do poema, a absolvição nunca ocorrerá antes da penitência.

Ao colocar em sua lírica os espaços dissonantes, os tempos oníricos e as métricas que mimetizam a colonização britânica na ilha, mas que também reforçam o caráter de denúncia e de violência de outras sociedades que tiveram a experiência do colonialismo, as quais, por vezes, ainda sofrem os efeitos dessa numa relação de "em-dependência", o poeta conecta, infalivelmente, sua arte à vida e a vida à arte. Como consequiência, sem reduzir

\footnotetext{
${ }^{163}$ Original: "Orpheus, let us not forget, had persuaded the King of the Dead to change the laws of the land of the dead, and to allow Eurydice to go back to the land of the living. And Orpheus... will do what poets always do: they will listen to the music of what is actually happening, but they will answer it by playing the music of what might happen". (HEANEY, 2002)
} 
esteticamente as suas técnicas e inovações, colocando elementos localmente fixados como o pentâmetro jâmbico e as redondilhas, Heaney propaga uma arte que se mantém ligada à sociedade por meio de seu caráter de resistência, ou seja, não se rendendo a uma comunicação fácil, mas problematizando sua relação com essa mesma sociedade.

Como conclusão, após esse caminho de análise, compreendemos que a poesia de Heaney, semelhantemente ao triskele celta, propõe um final não feliz, mas aberto ao futuro, justamente porque a mundanidade e a pluralidade humanas não podem irremediavelmente ser perdidas. Assim sendo, corpo, mente e alma se transformam em pluralidade, culpa e liberdade, como um moinho que não faz o autor perder seu passo mesmo, mas compreender, adicionar e, finalmente, reinventar espaços em que a arte e a vida ainda podem oferecer algo de resistência negativa, não carregando somente o impulso anárquico e individualista do presente. Entretanto, ao mesmo tempo em que recusa um determinismo histórico, o poeta consegue refletir sobre uma sociedade mais justa e humana. Assim, sua arte será um antídoto e um remédio contra as posições fundamentalistas, que não admitem uma compreensão de valores sociais e culturais. No contexto do pós-modernismo, observamos que esta poesia se enquadra e espelha as questões que, por serem urgentes, demandam uma maior atenção.

Resta-nos, portanto, compreender se a geração de Heaney e a anterior carregam suas mesmas preocupações. 


\section{BiBLIOGRAFIA}

1. SEAMUS HEANEY

Heaney, Seamus. Death of a Naturalist. London \&Boston: Faber and Faber, 1966.

Door into the Dark. London \& Boston: Faber and Faber, 1969.

. Wintering Out. London \& Boston: Faber and Faber, 1969.

. Stations. London \& Boston: Faber and Faber, 1975.

North. London \& Boston: Faber and Faber, 1975.

. Field Work. London \& Boston: Faber and Faber, 1979.

. Station Island. London \& Boston: Faber and Faber, 1984.

. The Haw Lantern. London \& Boston: Faber and Faber, 1987.

Death of a Naturalist. London \& Boston: Faber and Faber, 1991.

. The Spirit Level. London \& Boston: Faber and Faber, 1996.

. Preoccupations: Selected Prose 1968 - 1978. Faber and Faber:

London, 1980.

The Government of the Tongue. London: Faber and Faber, 1988.

\section{SOBRE HEANEY}

Arantes, José Antonio. In: Seamus Heaney - Poemas. São Paulo: Cia das Letras, 1998.

Ascher, Nelson. "Seamus Heaney ganha o Prêmio Nobel”. Folha de São Paulo, Caderno Ilustrada, 6 de outubro de 1995.

Barroso, I. “O escavador da Infância”. In. Folha de São Paulo, Caderno Ilustrada, s/d.

Curtis, Tony. The Art of Seamus Heaney. Wales: Poetry of Wales Press, 1985.

Elmer Kennedy \& Andrews.The Poetry of Seamus Heaney - A readers guide to essential criticism. Cambridge: Icon Books, 2000.

Homem, Rui Carvalho. “'Unroofed Scope'?: Heaney in the Nineties”. In. ABEI Journal - The Brazilian Journal of Irish Studies. Number 1, June 1999, pp. 29-42. 
Morrison, Blake. "The Guttural Muse of County Derry." Guardian Weekly. 15 de outubro de 1995.

Nolasco, Sonia. "Uma gota de Sangue Irlandês" O Estado de São Paulo, Caderno 2, 31 de maio de 1996.

O'Brien, Eugene. Seamus Heaney - Creating Irelands of the mind. Dublin: The Liffey Press, 2002.

Vendler, Helen. Seamus Heaney. London: Fontana Press, 1999.

Vono, Augusta. "Poeta ligado em suas Raízes Irlandesas". O Estado de São Paulo, Caderno 2, 14 de outubro de 1995.

Vizioli, Paulo. "Versos Bucólicos de Seamus Heaney saem em Português". O Estado de São Paulo.

3. GERAL

Adorno, THEODOR W. "Sartre e Brecht, Engajamento na Literatura". Cadernos de Opinião $n^{o}$. 2. Rio de Janeiro: Inúbia, s/d: pp. 28-37.

1993.

Minima Moralia .Trad. de Luiz Eduardo Bicca. São Paulo: Ática,

Editora 34, 2003.

Notas de Literatura I. Tradução: Jorge de Almeida. São Paulo:

Verso, 1980.

. "Reconciliation Under Duress". In. Aesthetics and Politics. London:

Alfoldy. A. Conflict of Ideas in the Late Roman Empire: The Clash between the Senate and Valentinian. Oxford: Oxford University Press, 1952.

Alighieri, Dante. The Divine Comedy of Dante Alighieri. Translation by Robert Turner. New York: Oxford University Press, 1996.

Agostinho. Confissões. Coleção Os Pensadores. São Paulo: Nova Cultural, 2000.

Arendt, Hannah. A Condição Humana. Rio de Janeiro \& São Paulo: Editora Forense Universitária, 1958.

Annunciação, Viviane Carvalho da. Seamus Heaney: Poética do Exílio. FAPESP, 2004/2005. 
ARISTÓteles. "Da Poesia e da Imitação segundo os meios, o objeto e o modo". Arte Poética. Disponível em www.charleskiefer.com.br/oficina/textos/Poetica.PDF. Acesso em 18 de julho de 2006, às $14 \mathrm{~h} 10$.

AuERBACH, ERICH. Mimesis: A Representação da Realidade na Literatura Ocidental. São Paulo: Perspectiva, 2004.

BAKHTin, MiKhaIL. Marxismo e Filosofia da Linguagem. Hucitec, São Paulo, 1979.

Barroso, Ivo. "O escavador da Infância". In. Folha de São Paulo, Caderno Ilustrada, s/d.

Bearton, Fran. The Great War in Irish Poetry - W. B. Yeats to Michael Longley. Great Britain: Oxford, 2003.

BeJA, Morris. James Joyce: A Literary Life. London: Macmillan, 1992.

Benjamin, WALter. "Sobre alguns temas em Baudelaire". In. Textos Escolhidos Horkheimer, Theodor W. Adorno e Jürgen Habermas. Trad.: José Lino Grünnewald [et. al.]. São Paulo: Abril Cultural, Os Pensadores, 1989, p. 29-56.

Magia e técnica, arte e política. Ensaios sobre literatura e história da cultura. São Paulo: Brasiliense, 1987.

Bнавна, Homi K. O local da Cultura. Tradução de Myriam Ávila, Eliana Lourenço de Lima Reis e Gláucia Renata Gonçalves. Belo Horizonte: Editora UFMG, 2003.

University Press, 2002.

; Chakrabarty, Dipesh. Cosmopolitanism. Duham \& London: Duke . "The Third Space". In. RUTHERFORD, JONATHAN (ed.) Identity: Community, Culture, Difference. London: Lawrence \& Wishart, 1990, 207-221.

Bíblia Sagrada. Jiménez, Pe. Manuel, et. al. (trad.). São Paulo: Edições Loyola, 1989.

Brown, TERENCE. Ireland: A Social and Cultural History 1980 - 2002. London: Harper Perennal, 2004.

"The Witnessing Eye and the Speaking Tongue". In. ElMER, ANDREWS (org.) Seamus Heaney: A Collection of Critical Essays. New York: St. Martin's Press, 1992.

CAmbridge, Gerry. "Philip Hobsbaum in conversation". In. Dark Horse: The Scottish American Poetry Magazine. Issue 14, Summer 2002, p. 31. Disponível em http://www.star.ac.uk/darkhorse.html. Acesso em 2 de abril de 2007, às $12 \mathrm{~h} 00$.

CAndido, Antonio. Textos de Intervenção. São Paulo: Duas Cidades e Editora 34, 2002. 
Literatura e Sociedade. São Paulo: Editora Nacional, 1976.

O Observador Literário. São Paulo: Ouro sobre Azul, 2004.

Carey, John. "The Most Sensuous Poet to use English Since Keats". Sunday Times. 3 de abril de 1988.

Castorina, Giuseppe. "Dante e il poetico mondo di Seamus Heaney". Quaderni Del Premio Litterario Giuseppe Acerbi. $11^{\circ}$ Edizione. Irlanda: Commune di Castel Goffredo Associazione Giuseppe Acerbi, s/d.

Chakrabarty, Dipesh. Provincializing Europe - Postcolonial thought and Historical Difference. New Jersey: Princeton University Press, 2000.

Cleary, Joe. "Postcolonial Ireland". In: Kenny, Kevin (ed.). Ireland and the British Empire. Oxford: Oxford University Press, 2004.

Comay, Rebecca. In: Benjamin, Andrew; Osborne, Peter (orgs.). A Filosofia de Walter Benjamin - Destruição e Experiência. Tradução: Maria Luiza X de A. Borges. Rio de Janeiro: Jorge Zahar Editor, 1994.

Corcoran, NeIL. A Student's Guide to Seamus Heaney. London and Boston: Faber and Faber, 1986.

. After Yeats and Joyce: Reading Modern Irish Literature. Oxford \& New York: Oxford University Press, 1997.

CAIRnS, DAVID; Richards, Shaun. Writing Ireland: Colonialism, Nationalism and Culture. Manchester: Manchester University Press, 1988.

Craith, MÁiréAd Nic. Plural Identities - Singular Narratives. The Case of Northern Ireland. New York: Berghahn Books, 2002.

Deane, Seamus. Strange Country: Modernity and Nationhood in Irish Writing since 1790. Oxford: Clarendon Press, 1997.

Nationalism, Colonialism and Literature. London \& Minneapolis: University of Minnesota Press, 1997.

DERRIDA, JACQUES. "A estrutura, o signo e o jogo no discurso das ciências humanas" In: COELHO, EDUARDO PRADO (org.). Estruturalismo: antologia de textos teóricos. Martins Fontes, 1967.

The Ear of the Other - Otobiography, Transference, Translation. English edition edited by Christie McDonald and translated by Avital Ronell. Lincon \& London: University of Nebraska Press, 1982. 
"Economimeses" In: Wilfrey, Julian (org) The Derrida Reader. Edinburgh: Edimburg University Press, 1998, pp. 263-293.

. "A Solidariedade dos Seres Vivos". Folha de São Paulo. Caderno Mais.

São Paulo, 27 de maio de 2001.

Dews, PeTER. "Adorno, pós-estruturalismo e a crítica da identidade". In. ZizeK, SLAVou (org.) Um mapa da Ideologia. Trad: Vera Riberio. São Paulo: Contraponto, 1999, pp. 5170 .

Eagleton. Terry. "New Poetry: Review of Seamus Heaney". Field Work, in Stand, 23, 1. 1980.

Eliot, T. S. Selected Essays - 1917 - 1932. New York: Harcourt, Brace and Company, 1932.

Easthope, Antony. Poetry as Discourse. London \& New York: Methuen, 1983.

Elmer Kennedy \& Andrews. The Poetry of Seamus Heaney - A readers guide to essential criticism. Cambridge: Icon Books, s/d.

Fennell, Desmond. The State of the Nation: Ireland Since the Sixties. Swards: Ward River Press, 1983.

Foucault, Michel. "Ditos e Escritos". In: Problematização do Sujeito: psicologia, psiquiatria e psicanálise. Tradução Vera Lúcia Avellar Riberio. Rio de Janeiro: Forense Universitária, 1999.

Freud, Sigmund; Hall, G. Stanley. "Wish Fulfillment". In: A General Introduction to Psychoanalysis. New York: Horace liveright, 1920.

Freud, Sigmund. Edição Standard Brasileira das Obras Psicológicas Completas de Sigmund Freud. Volume XIX O Ego e o Id e Outros Trabalhos. Traduzido por Jayme Salomão. Rio de Janeiro: Imago Editora Ltda, 1976.

Gray, PAUl. "A Poet of the Threshold.” Time. Nobel Prize. 16 de outubro de 1995.

GRAY, BREDA."Unmasking Irishness: Irish Women, the Irish Nation and the Irish Diaspora." In: MACLAUGHLIN, JIM (ed.) Location and Dislocation in Contemporary Irish Society. Emigration and Irish Identities. USA: University of Notre Dame Press, 1997, pp. 209-235.

Hachey, Thomas E; Hernon JR., Joseph M. Joseph M.; McCaffrey. The Irish Experience: A Concise History. Armonk, New York: M. E. Sharpe, 1996.

Hall, Stuart; MirzoefF, Nicholas (ED.). Diaspora and Visual Culture. Representing Africans and Jews. London \& New York: Routledge, 1999. 
Hamburger, Michael. The Truth of Poetry. London: Anvil Press, 1969.

Harjo, Joy. How we Became Human - New and Selected Poems. New York \& London: W.W. Norton; Company, 2000.

Horace. The complete Odes and Epodes. Translated by David West. Oxford: Oxford University Press, 2000, p. 98.

HorÁCiO. Arte Poética. Introdução, Tradução e Comentário de R. M. Rosado Fernandes. Lisboa: Editorial Inquérito Ltda., 1984.

Hughes, Francis. Republican POW, Long Kesh. $10^{\text {th }}$ of March, 1981. Disponível em irelandsown.net/fhughes.htmlirelandsown.net/fhughes.html. Acesso em 15 de novembro de 2006 , às $18 \mathrm{~h} 29$.

Hutcheon, Linda. The Last Post. Theorizing Post Colonialism and Post-Modernism. New York; London: Harvester Wheatsheaf, 1991.

Izarra, Laura; Mutran, Munira H. Irish Studies in Brazil. São Paulo: Humanitas 2005.

JAMESOn, FREDRIC. "Beyond the Cave". The Ideologies of Theory: Essays 1971 - 1986. Volume 2: The Syntax of History. London: Routledge, 1987.

JoYCe, JAMES. Stephen Hero. Disponível em http://theliterarylink.com/joyce.html. Acesso em 26 de novembro de 2006, 9h00.

KeARney, Richard. Transitions. Narratives in Modern Irish Culture. Manchester: Manchester University Press, 1988.

KIBERD, DECLAN. Inventing Ireland - The Literature of the Modern Nation. Dublin: Vintage, 1996.

Irish Classics. London: Granta Books, 2000.

Kinsella, Thomas. The Dual Tradition - Essays on Poetry and Politics in Ireland. Manchester: Carcan \& Peppercanister, 1995.

Kristeva, Julia. "Nous deux' or a (hi)story of intertextuality". The Romanic Review, Vol. 93, 2002.

LACAN, JACQUES. Écrits - A Selection. Bristol: Tavistock/Routledge. 1992.

LLOYD, DAVID. "Regarding Ireland in a Postcolonial Frame". In: Ireland after History. United States: University of Notre Dame Press \& Field Day, 1999.

Anomalous States - Irish Writing and the Post-colonial moment.

Durham: Duke University Press, 1993. 
LONGLEY, EDNA. The Living Stream. Glasgow: Bloodaxe Books, 1994.

LÖwy, Michel; Moraes, Denis (ORG). Combates e Utopias. Rio de Janeiro; São Paulo: Editora Record, 2004.

LUKÁCS, GYÖRGY. Ensaios sobre Literatura. Coordenação e pref. de Leandro Konder. Rio de Janeiro: Civilização Brasileira, 1965.

MacCabe, Colin. James Joyce - New Perspectives. Brighton, Sussex; Bloomington: Indiana University Press, 1982.

MacCulloch, John A. The Religion of the Ancient Celts. United States: Kessinger Publishing, 2003.

MacNiece, Louis. Modern Poetry: A Personal Essay. London: Oxford University Press, 1939.

MAnn, PAUl DE. Alegorias de Leitura: Linguagem Figurativa em Rousseau, Nietzsche, Rilke e Proust. Trad. Lenita R. Esteves. Rio de Janeiro, Imago, 1996.

MATthews, Steven. "Reconciliation under Duress': The Architecture of Seamus Heaney's Recent Poetry". In. Irish Poetry: Politics, History, Negotiation: The Evolving Debate, 1969 to the Present. London: Macmillan Press Ltd, 1997, pp. 158-186.

MCHugh, Roger; Harmon, MAurice. In. Anglo-Irish Literature - From Its Origins to the Present Day. Totowa, New Jersey: Barnes and Noble Books, 1982.

McDonald, Peter. Serious Poetry - Form and Authority from Yeats to Hill. Oxford: Carledon Press, 2002.

Montague, John. Poisoned Lands and Other Poems. London: MacGibbon and Kee, 1961.

Mutran, Munira Hamud; IZARRA, LAURA P. Z. (ed) Kaleidoscopic views of Ireland. São Paulo: Humanitas FFLCH/USP, 2003.

NitRINI, SANDRA. "Intertextualidade". In. Literatura Comparada. São Paulo: EDUSP, 2000 .

O'ToOle, Fintan. "The Ex-Isle of Erin: Emigration and Irish Culture”. Mac Laughlin, Jim (ed.) Location and Dislocation in Contemporary Irish Society. Emigration and Irish Identities. USA: University of Notre Dame Press, 1997, pp. 158-178.

O'Malley, Padraig. Biting at the Grave: The Irish Hunger Strikes and the Politics of Despair. Boston: Beacon Press, 1990, p. xi. 
PaZ, Octavio. O Arco e a Lira. Trad. Olga Savary. Rio de Janeiro: Nova Fronteira, 1956.

PAKEnham, JaCK. "The Belfast Group: A Symposium". The Honest Ulsterman. Issue 53. December 1976.

Perrone-Moisés, LeYla. Flores da Escrivaninha. São Paulo: Companhia das Letras, 1990.

Quintino, Cláudio. A Religião da Grande Deusa. São Paulo: Gaia, 2002.

SchneIDER, DAvid. American Kinship. A Cultural account. Nova Jersey: Prentice Hall, 1968.

SAID, Edward. Reflexões sobre o Exílio e Outros Ensaios. São Paulo: Companhia das Letras, 2003.

Letras, 1999.

. Cultura e Imperialismo. Tradução: Denise Bottman. São Paulo: Cia. das "Intellectuals: Expatriates and Marginals" In: Grand Street 47, 1992.

Schwartz, Henry; Ray, Sangeeta Ray (ed.). A Companion to Post Colonial Studies. Malden: Blackwell Publishing, 2000.

Spivak, Gayatri Chakravorty. In Other Worlds - Essays on Cultural Politics. New York and London: Routledge, 1988.

1993.

Outside in the teaching machine. New York: Routledge,

"Can the Subaltern Speak?" In: Williams, PATRICK; L.

Chrisman (eds.) Colonial Discourse and Postcolonial Theory: A Reader. New York: Harvester, 1993.

White, Hayden. Figural Realism - Studies in the Mimesis Effect. Baltimore: The Johns Hopkins University Press, 2000.

WiLliams, RaYmond. Marxism and Literature. Oxford; New York: Oxford University Press, 1977.

Woolf, Virginia. The Common Reader. London: The Hogarth Press, 1957.

ZizeK, Slavoj. "Cogito and the Sexual Difference The Kantian Crack in the Universal". Tarrying with the Negative Kant, Hegel, and the Critique of Ideology. Durham: Duke University Press, 1993, pp. 45-124. 